\title{
Metals in subduction related magmatism: Insights from melt inclusions and associated glassy groundmass from the Southern Kermadec Arc, New Zealand
}

By

Jacob Morgan Leath

A thesis submitted to Victoria University of Wellington in partial fulfilment of the requirements for the degree of Master of Science in Geology

School of Geography, Environment and Earth Sciences

Victoria University of Wellington, New Zealand

March 2019

TE WHARE WĀNANGA O TE ŪPOKO O TE IKA A MĀUI

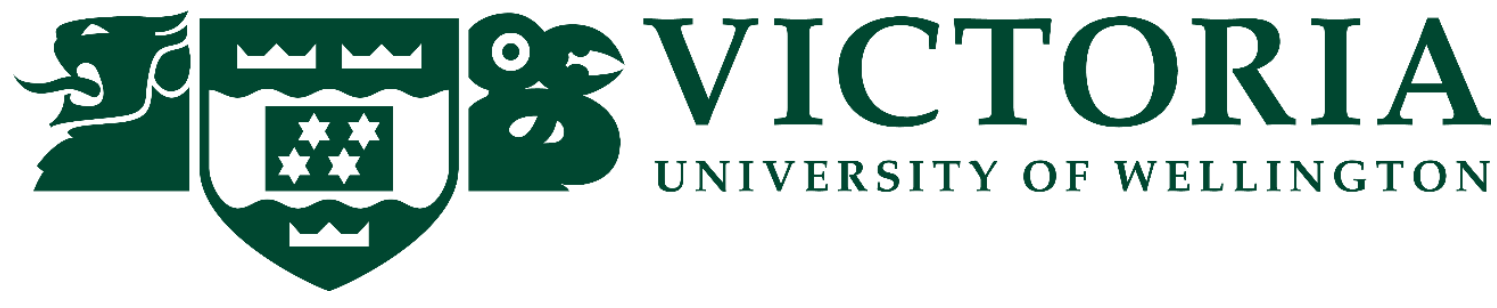




\section{Abstract}

The southern Kermadec Arc - Havre Trough (SKAHT) is an intra-oceanic arc back-arc system where the Pacific plate is subducting beneath the Australian plate. The Kermadec volcanic arc front consists of 33 volcanic centres, four of which host hydrothermal mineralization (Brothers, Haungaroa, Rumble II West, and Clark) such as volcanogenic massive sulfide (VMS) deposits, which are characterised by high concentrations of base and precious metals (e.g., $\mathrm{Au}, \mathrm{Cu}, \mathrm{Zn}, \mathrm{Pb}$ ). The sources of these metals are strongly tied to the metal contents within underlying magmatic rocks and associated magmatic systems with which the hydrothermal fluids interact. Understanding the sources, movements, and accumulation of metals associated with porphyry copper and exhalative base metal deposits within a subduction - arc setting remains limited.

This study reports major, trace, and volatile element contents in basaltic groundmass glasses and olivine-hosted melt inclusions from lavas from four locations within the arc - back-arc setting of the SKAHT. The focus is on understanding the controls on base metal $(\mathrm{Pb}, \mathrm{Cu}, \mathrm{Zn}, \mathrm{Mo}, \mathrm{V})$ contents in the magmas. The sample locations, Rumble III and Rumble II West volcanoes, and back-arc Basins D and I, form an arc-perpendicular transect extending from arc front into the back-arc. The analysed melt inclusion and groundmass glasses are all basalt to basaltic andesite in composition, with back-arc basin samples more mafic than arc front volcano samples. The magmatic evolution of the melts is primarily controlled by crystal fractionation of olivine + pyroxene + plagioclase. All glasses have undergone variable degassing, indicated by an absence of detectable $\mathrm{CO}_{2}$ and curvilinear decreases in $\mathrm{S}$ contents with increasing $\mathrm{SiO}_{2}$. Of the volatile phases analysed, only $\mathrm{Cl}$ appears unaffected by degassing.

Distinct compositional differences are apparent between arc front and back-arc melts. The arc front magmas formed from higher degrees of melting of a less fertile mantle source and are more enriched in trace elements then the back-arc magmas due to greater additions of slab-derived aqueous fluids to their source. Magmas from a 
single arc front volcano (Rumble II West) incorporate melts that have tapped variably enriched sources, indicating heterogeneity of the mantle at small scales. Significant variation in mantle composition, however, is also apparent laterally along strike of the arc. Rumble III volcano and Basin I lie on an arc-perpendicular transect south of Rumble II West volcano and Basin D. Their greater enrichment in trace elements and higher concentrations of base metals than Rumble II West and Basin D lavas can be attributed to higher fluxes of subduction derived components.

Base metals ( $\mathrm{Cu}, \mathrm{Zn}, \mathrm{Pb}, \mathrm{Mo}$, and $\mathrm{V})$ are variably enriched in the SKAHT melts compared with typical mid-ocean ridge basalts with relative enrichments in the order $\mathrm{Pb}>\mathrm{Cu}>\mathrm{Mo}, \mathrm{V}>\mathrm{Zn}$. All metals appear to be affected by mantle metasomatism related to slab-derived fluids, either directly from slab components introduced to the mantle source (e.g., $\mathrm{Pb}$ ) or through mobilisation of metals within the ambient mantle wedge. The apparently compatible behaviour of $\mathrm{Zn}, \mathrm{Cu}$, and $\mathrm{V}$ in the mantle means that these elements may be enriched in arc front magmas relative to back-arc magmas by higher degrees of partial melting and/or melting of more depleted sources.

All base metals behave incompatibly in the magma during crystal fractionation between $48-56$ wt.\% $\mathrm{SiO}_{2}$. Lead and Cu concentrations, however, begin to level out from $\sim 52 \mathrm{wt} . \% \mathrm{SiO}_{2}$ suggesting some subsequent loss to fractionating volatile phases as metal sulfide complexes. Rumble III samples show a decrease in metal concentration $(\mathrm{Pb}, \mathrm{Cu}, \mathrm{V})$, from melt inclusions to groundmass glasses, suggestive of more significant loss associated with sulfur degassing.

Although other factors such as heat generation, hydrothermal flow, fault systems, and magma venting are key in the development of VMS deposits, this study shows that variations in subduction parameters can significantly affect metal concentrations in arc magmas that may host hydrothermal systems, and hence the amount of metals available to be scavenged into the deposits. 


\section{Acknowledgements}

A huge and heartfelt thanks goes firstly to my supervisors, Monica Handler, Richard Wysoczanski, Ian Schipper, and Christian Timm for taking me on. The wealth of support, guidance, and patience you provided was the keystone of this endeavour.

Monica, thank you for keeping me in the right direction. Your time, feedback, and moral support made all difference and kept me going. Richard, thank you for being a huge technical and educational help at every step along the way, from early picking of olivines right through to final touches on the thesis. Ian, thank you for holding my hand through both FTIR and probe analyses, as well as all the equipment and tricks that made sample preparation a little less painful. Christian, thank you for the huge help sourcing the samples and your critical feedback at the end stages.

An enormous thanks to my parents, I couldn't have undergone this study without your love and financial support. Most importantly, thank you for keeping me well fed, the hundreds of Up\&Gos were crucial.

Thanks to the group of geology buddies here at VUW you all made the process a million times more enjoyable. Although a couple were notoriously distracting (you know who you are), I am glad to have met everyone and hope to keep close. To all my friends outside of the university, thanks for always giving me an escape where I can regain my sanity. 


\section{Contents}

Abstract ... iii

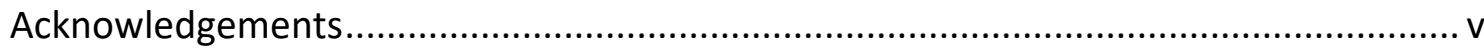

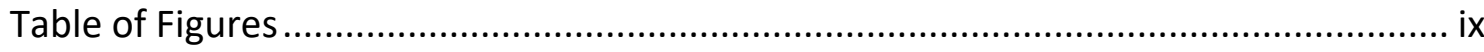

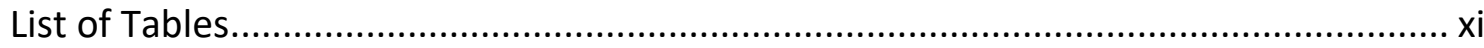

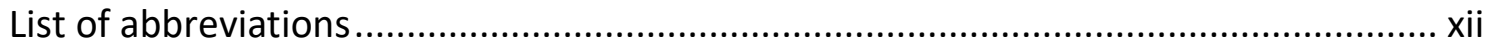

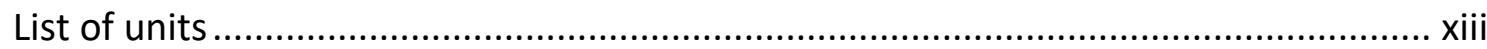

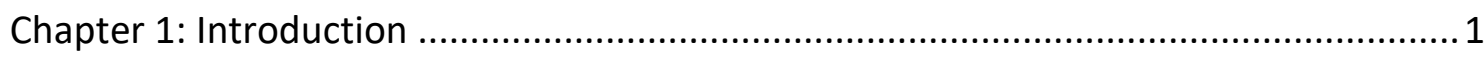

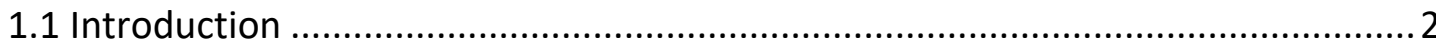

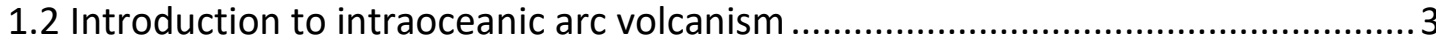

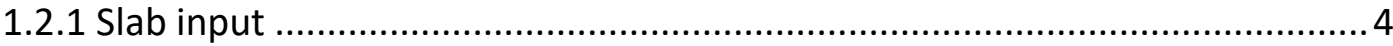

1.2.2 Partial melting of the mantle, crystal fractionation and crustal assimilation . 6

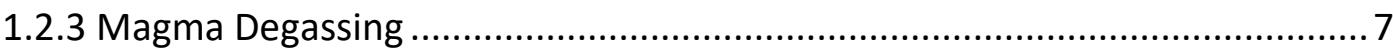

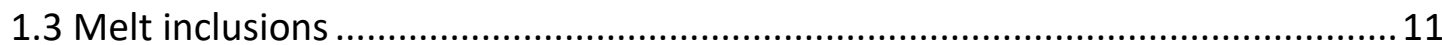

1.4 Volcanogenic Massive Sulfide deposits and base metals in arc settings.............. 11

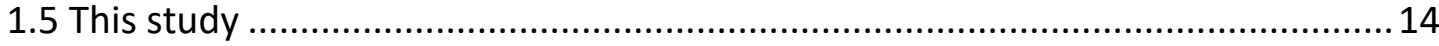

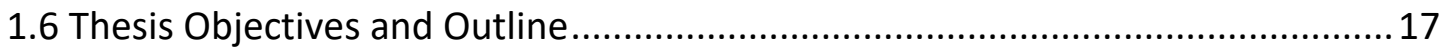

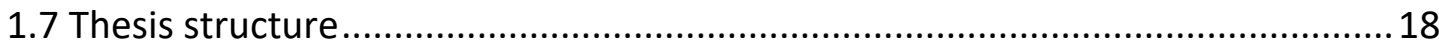

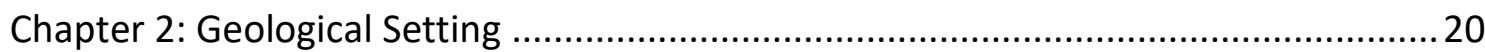

2.1 Overview of the Kermadec Arc-Havre Trough back-arc system and subduction

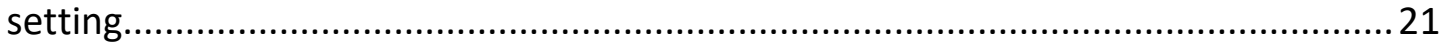

2.2 Southern Kermadec Arc - Havre Trough Magmatism and Volcanism .................24

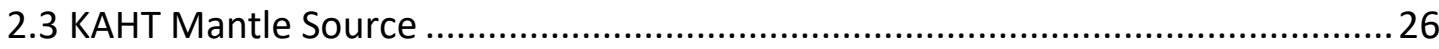

2.4 Chalcophile and Siderophile elements in the KAHT ............................................2 28

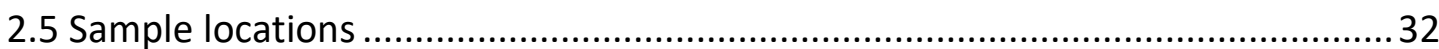

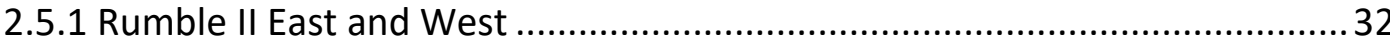

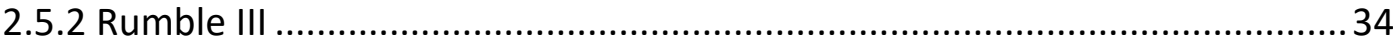

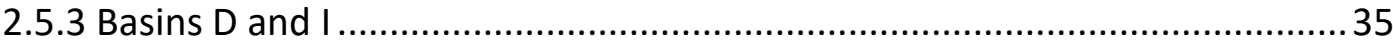

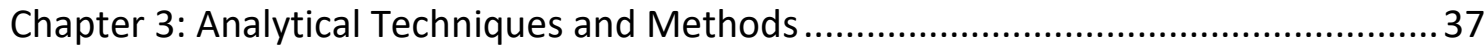

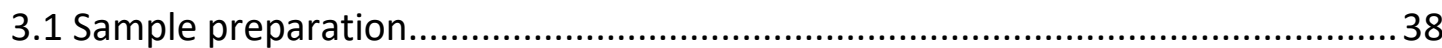

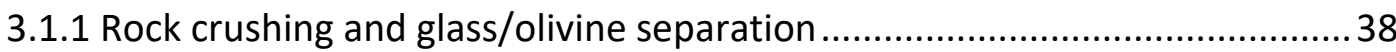

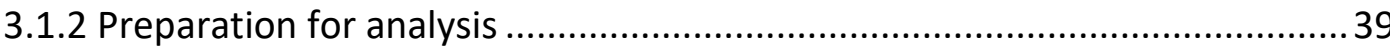

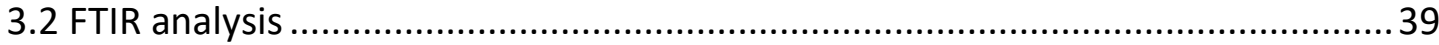

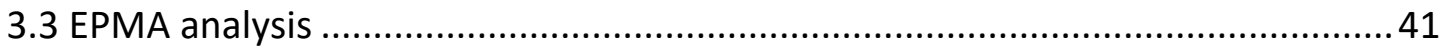




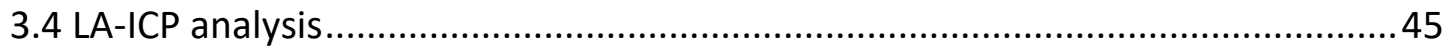

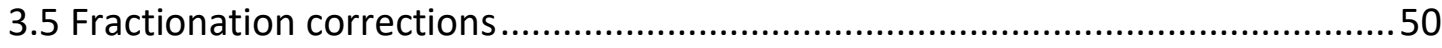

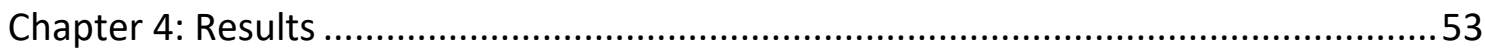

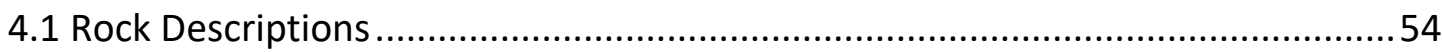

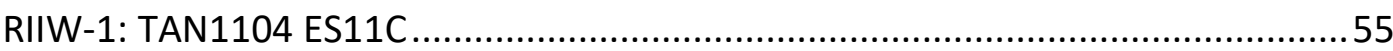

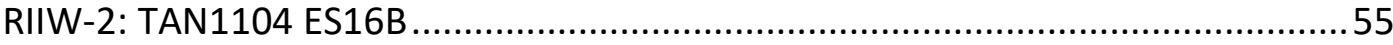

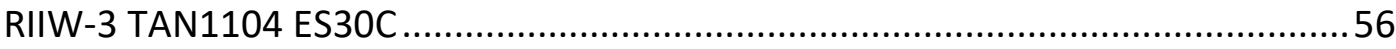

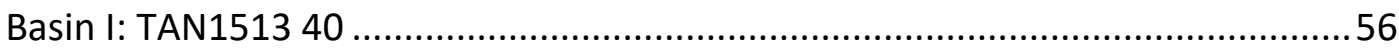

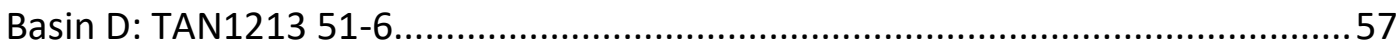

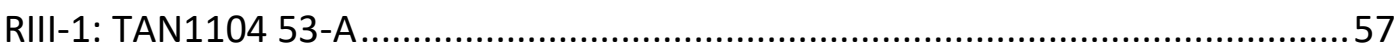

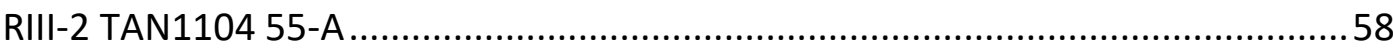

4.2 Olivine grains and associated melt inclusions: .................................................58

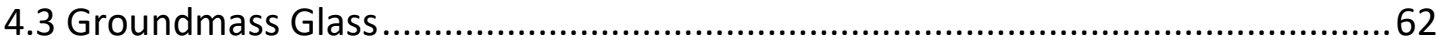

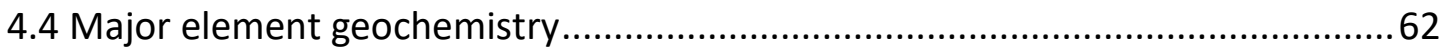

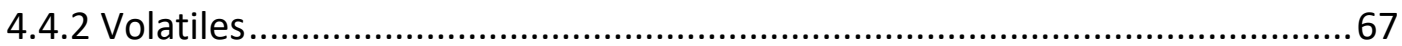

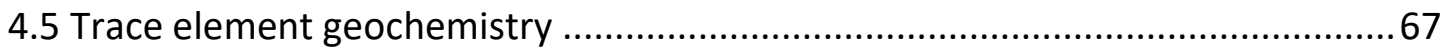

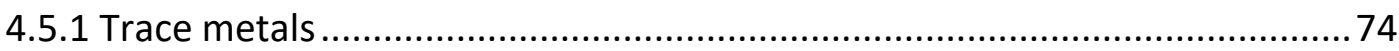

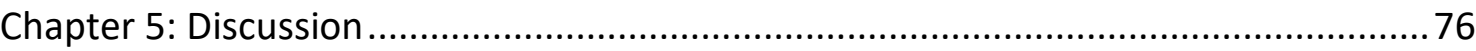

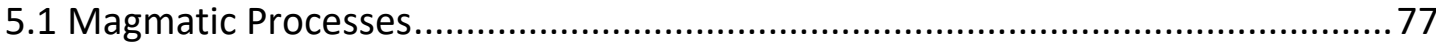

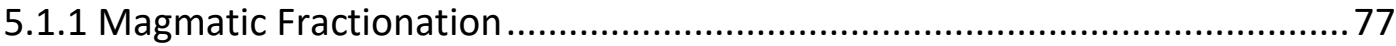

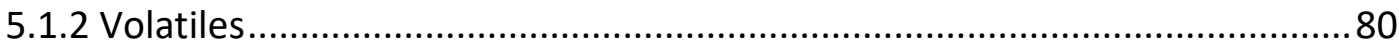

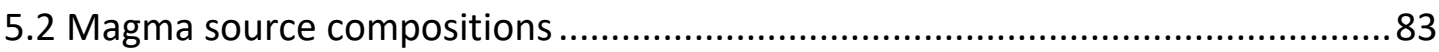

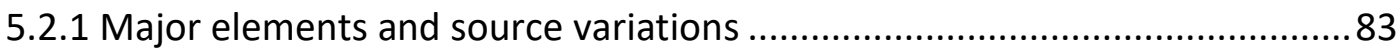

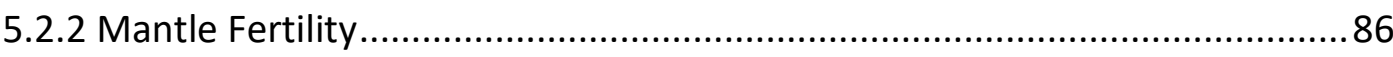

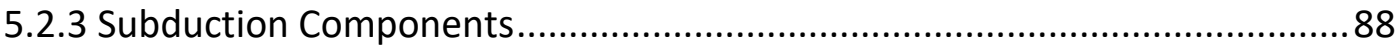

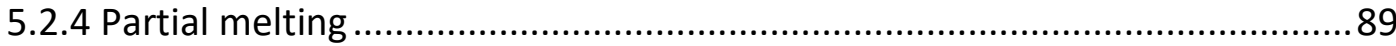

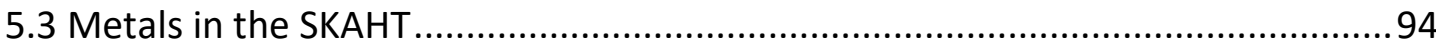

5.3.1 Metals during magma evolution ...............................................................94

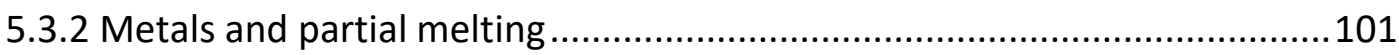

5.3.3 Subduction related metal inputs ..........................................................103

5.4 SKAHT metals and VMS deposits ................................................................107

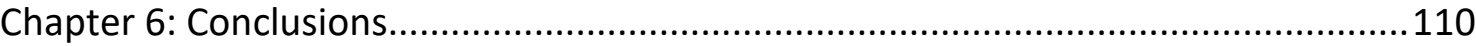

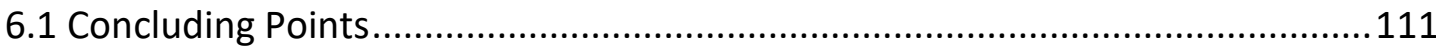

6.2 Suggestions for future studies ........................................................................113 


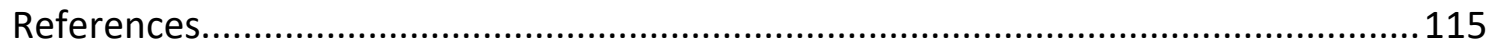

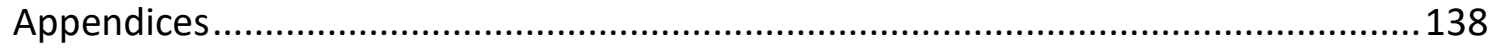

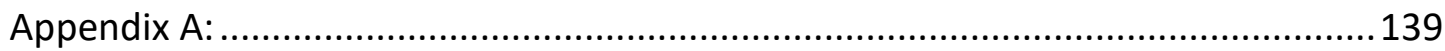

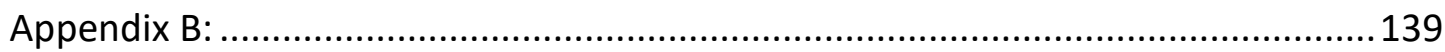

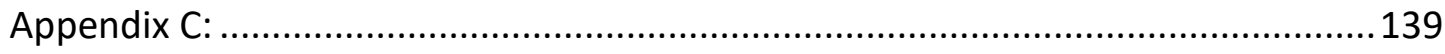

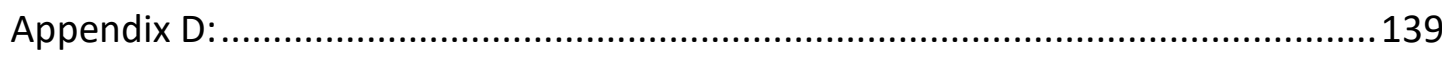




\section{Table of Figures}

Figure 1.1: Schematic model of oceanic subduction zone magmatism

Figure 1.2: Degassing trends for $\mathrm{H}_{2} \mathrm{O}$ and $\mathrm{CO}_{2}$ for basalts

Figure 1.3: Schematic model of a submarine hydrothermal system and cross-section of a typical volcanogenic massive sulfide deposit 13

Figure 1.4: Regional map of the southern Kermadec Arc - Havre Trough 16

Figure 2.1: Regional bathymetric map of the Kermadec - Tonga Arc, Havre Trough Lau Basin back-arc.

Figure 2.2: Silica vs. total alkalis for Kermadec Arc lavas. 25

Figure 2.3: Select trace elements vs. $\mathrm{SiO}_{2}$ of Kermadec Arc lavas. 30

Figure 2.4: Along arc variations of trace metals/Yb and Bi/Nd*100 of Kermadec Arc lavas.

Figure 2.5: Bathymetric map of Rumble II East and Rumble II West

Figure 2.6: Gravity model if Rumble II East and Rumble II West 33

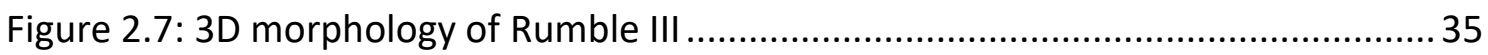

Figure 2.8: Bathymetric maps of Basin D and Basin I 36

Figure 4.1: Plane polarised light photos of polished olivine grains and a plagioclase grain.

Figure 4.2: EPMA back-scatter imaging of olivine grains showing rim compositional zoning.....

Figure 4.3: EPMA back-scatter imaging of olivine grains showing larger scale compositional zones

Figure 4.4: EPMA back-scatter imaging of olivine grains showing post entrapment olivine growth

Figure 4.5: EPMA back-scatter imaging of representative groundmass glass shards .... 62

Figure 4.6: Silica vs. total alkalis diagram of SKAHT glasses 63

Figure 4.7: Major, minor and volatile elements vs. $\mathrm{SiO}_{2}$ of SKAHT samples $65-66$

Figure 4.8: N-MORB-normalised multi-trace element diagram for SKAHT glasses. 69 - 71

Figure 4.9: Chondrite-normalised rare earth element plots of SKAHT glasses ....... 72 - 74

Figure 4.10: Trace metal elements vs. $\mathrm{SiO}_{2}$ of SKAHT glasses .75 
Figure 5.1: Volatile species in SKAHT olivine hosted melt inclusions 81

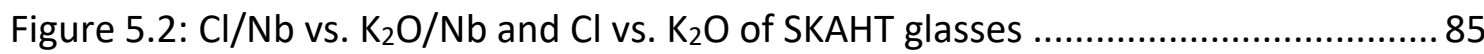

Figure 5.3: Select major elements of melt inclusions modelled to $8 \mathrm{wt} . \% \mathrm{MgO}$............ 86

Figure 5.4: Trace element ratio plots showing mantle fertility ( $\mathrm{Nb} / \mathrm{Yb})$, shallow (Ba/Th), deep $(\mathrm{Th} / \mathrm{Nb})$ and sediment melt $\left([\mathrm{La} / \mathrm{Sm}]_{\mathrm{n}}\right)$ subduction components of SKAHT glasses

Figure 5.5: Calculated degrees of partial melting of SKAHT melt inclusions vs. Ba/Nb, $\mathrm{Ba} / \mathrm{Th}, \mathrm{La} / \mathrm{Lu}$, and $\mathrm{Nb} / \mathrm{Yb}$ 91

Figure 5.6: Calculated degrees of partial melting vs. sample distances from the Kermadec Trench

Figure 5.7: Alkali elements $\left(\mathrm{Cl}\right.$ and $\left.\mathrm{K}_{2} \mathrm{O}\right)$ vs. shallow $(\mathrm{Ba} / \mathrm{Th})$ and deep ( $\left.\mathrm{Th} / \mathrm{Nb}\right)$ subduction components

Figure 5.8: Trace metal elements vs. $\mathrm{SiO}_{2}$ with enrichment/depletion vectors 96

Figure 5.9: Trace metal elements vs. Sulfur ${ }_{\text {total }}$ of SKAHT glasses. .98

Figure 5.10: Trace metal elements vs. $\mathrm{Cl}$ of SKAHT glasses 101

Figure 5.11: Trace metal elements normalised to $8 \mathrm{wt} . \% \mathrm{MgO}$ vs. calculated degree of partial melting 102

Figure 5.12: Variations of metals/ $\mathrm{Yb}$ and subduction inputs ( $\mathrm{Ba} / \mathrm{Nb}, \mathrm{Ba} / \mathrm{Th}, \mathrm{Th} / \mathrm{Nb}$, $[\mathrm{La} / \mathrm{Sm}]_{\mathrm{n}}$ 106 


\section{List of Tables}

Table 1.0-1: Arc front stratovolcano and back-arc basin samples investigated in this study

Table 3.0-1: Measured and preferred values of major and minor element abundances for glass standard VG-568

Table 3.0-2: Measured and preferred values of major and minor element abundances for glass standard VG-A99.

Table 3.0-3: Measured and preferred values of major and minor element abundances for glass standard VG2

Table 3.0-4: Measured and preferred values of major and minor element abundances for glass standard USNM 113716.

Table 3.0-5: Measured and preferred values of major and minor element abundances for olivine standard Springwater Olivine

Table 3.0-6: Measured and preferred values of major and minor element abundances for olivine standard JK3 Olivine

Table 3.0-7: Measured and preferred values for trace element abundances for glass standard BHVO-2-G

Table 3.0-8: Measured and preferred values for trace element abundances for glass standard BCR-2

Table 3.0-9: Measured and preferred values for trace element abundances for glass standard NIST612G

Table 3.0-10: $K_{D}$ values used for trace metals in olivine during Petrolog modelling .......51

Table 3.0-11: $K_{D}$ values used for trace metals in clinopyroxene during Petrolog modelling.

Table 3.0-12: $K_{D}$ values used for trace metals in plagioclase during Petrolog modelling..... 52

Table 4.0-1: Rock sample primary characteristics 54 


\section{List of abbreviations}

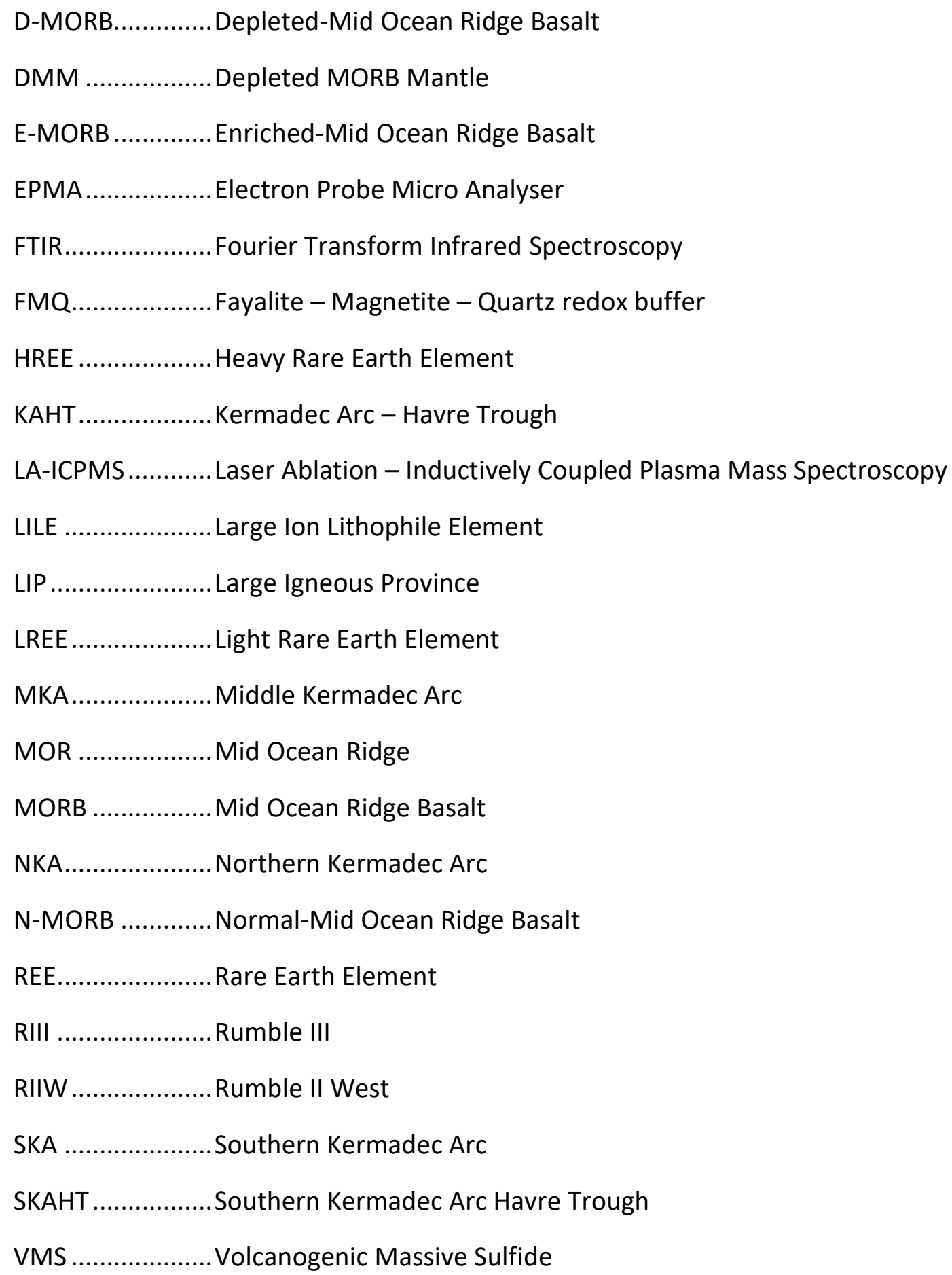




\section{List of units}

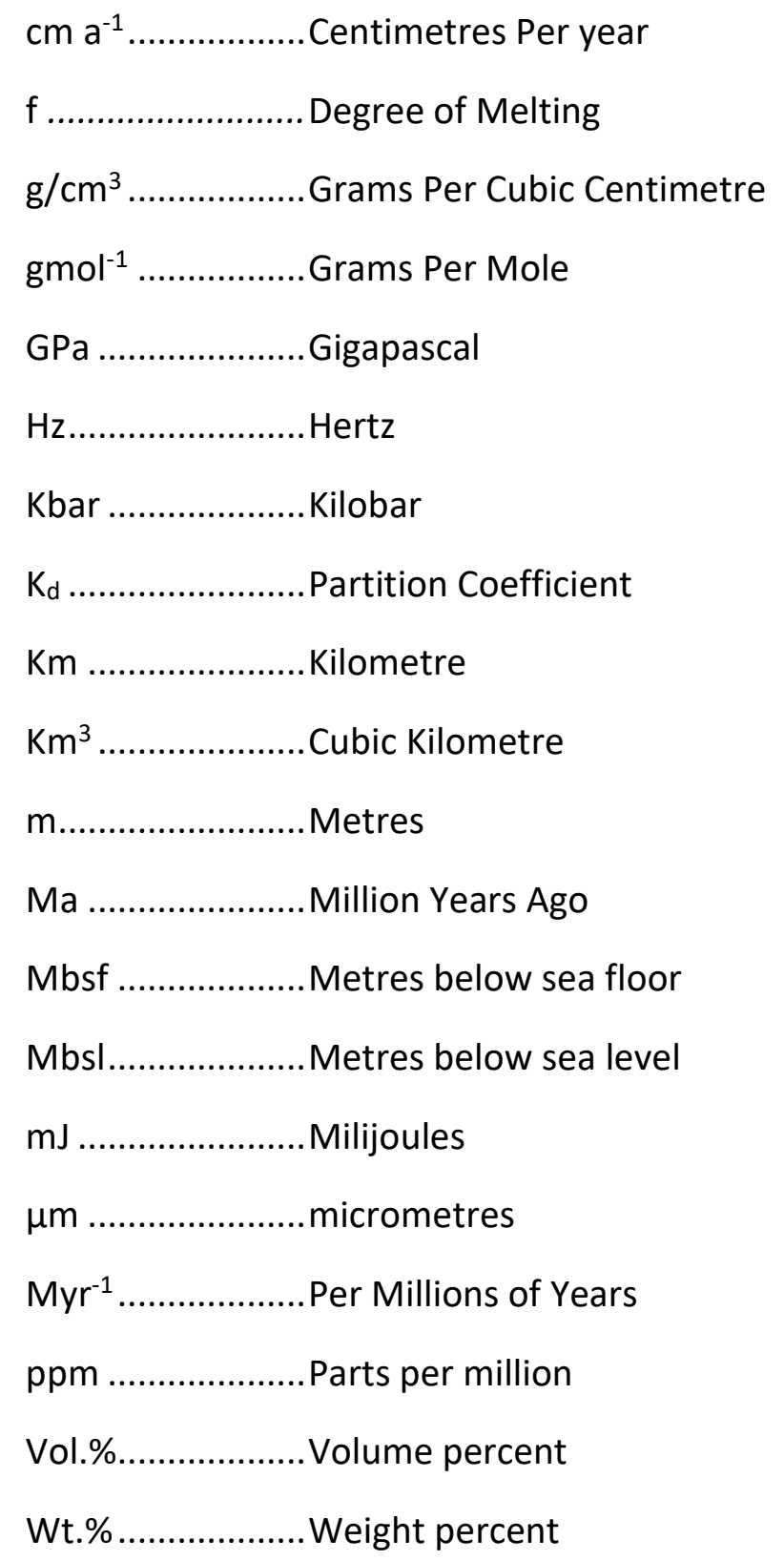


Chapter 1: Introduction 


\subsection{Introduction}

Subduction is the process where one tectonic plate is forced beneath another into the underlying mantle, mainly driven by density differences between the two plates. Subduction boundaries play an integral role in current plate dynamics (Bird, 2003) and instigate a host of geophysical and geochemical processes along and within the subduction zone. One key result is the formation of a chain of arc volcanoes (also termed volcanic arcs) that are the surficial expression of fluid flux-driven partial melting of the subarc mantle wedge that overlies the subducting plate. Intra-oceanic arc volcanism occurs where the converging plates are both oceanic, an archetypal example being the Kermadec Arc, which along with the associated Havre Trough backarc basin, is the focus of this study.

Subduction settings and associated arc magmatism are recognised as being important drivers of substantial element cycling amongst the mantle, crust, ocean, and atmosphere (Spandler et al., 2004; Wallace, 2005; Ryan and Chauvel, 2013; Bebout, 2014). The scale of this process is evident by the approximately 40,000 kilometres of subduction boundaries on Earth, with rates of subduction varying from $30-180 \mathrm{~km}$ Myr $^{-1}$ (Ryan and Chauvel, 2013).

Elemental movement between these reservoirs is driven, and impacted by, several key components and processes within the subduction setting. These processes include: slab recycling - transporting sediment, oceanic crust, and volatiles into the mantle, partial melting of the mantle, and crustal processes. Crustal processes include: crystal fractionation, degassing, magma mixing, and crustal contamination. Tracing element movement among these components and through the key processes operating in subduction zones is critical for unravelling how these processes operate and impact the elemental budget of arc melts, including that of base metals.

The budget and behaviour of volatile (e.g., $\mathrm{S}, \mathrm{H}, \mathrm{C}$, and $\mathrm{Cl}$ ) and base/trace metal (e.g., $\mathrm{Cu}, \mathrm{Zn}, \mathrm{Pb}$ ) components of melts are of importance for the formation of volcanogenic massive sulfide (VMS) deposits. VMS deposits are notable features of subduction arc settings and are potentially economically important (Hannington, 2014). Current understanding as to the source and movement of both volatiles and base metals in arc magmatic systems involved in sulfide complexes is limited (de 
Ronde et al., 2005, 2011; Wallace, 2005; Jenner et al., 2010; Timm et al., 2012; Wysoczanski et al., 2012).

This thesis presents an investigation into base metal and volatile element data in olivine hosted melt inclusions and associated groundmass glass in lavas from the southern Kermadec Arc - Havre Trough (SKAHT). The primary aim is to better constrain the movement of these elements through the arc magmatic system, from melting of the subduction modified mantle through to eruption along the arc and back-arc. Glassy groundmass material represents the composition of the relatively evolved melt that has quenched during eruption on the seafloor. Conversely, olivine hosted melt inclusions represent relatively primitive melt compositions as olivine is one of the first crystallising phases, prior to significant fractional crystallisation and devolatilisation (Wysoczanski et al., 2012). The composition of pristine melt inclusions should approximate that of the melt composition at the time of the olivine crystallisation. Coupling glassy groundmass and olivine hosted melt inclusions from the same lava samples allows for comparison between more evolved and relatively primitive melt compositions. This allows for the behaviour of the base metals and volatiles to be constrained throughout magmatic evolution, from magma genesis to eruption.

\subsection{Introduction to intraoceanic arc volcanism}

Subduction zone magmatism results from an interplay between several components and processes, each contributing to element mobility and transfer. Figure 1.1 is a schematic diagram summarising an intraoceanic arc magmatic setting, following partial melting of the mantle wedge through to eruption along the arc and back-arc. The processes throughout the system are described below. 


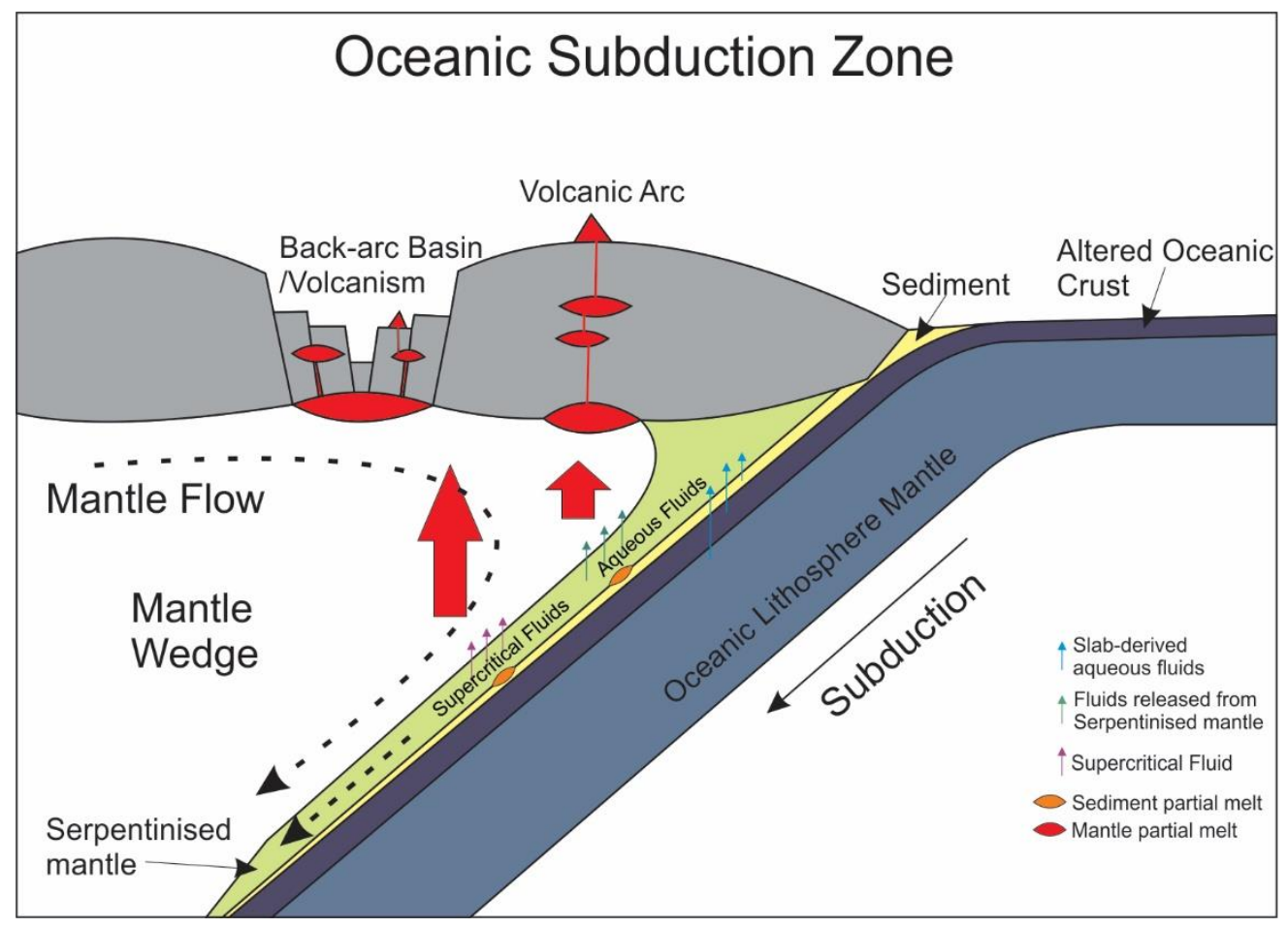

Figure 1.1: Schematic model of oceanic subduction zone magmatism showing fluid release from subducting sediment, altered oceanic crust and lithospheric mantle into the mantle wedge, as well as melt generation and migration towards volcanic arc front and back-arc. Modified from Wysoczanski et al. (2006).

\subsubsection{Slab input}

Slab input to the source of arc magmas is the materials derived from the subducting oceanic crust, mantle and sedimentary veneer, primarily transported as mobile phases (e.g., hydrous and melt phases). The subducting plate is composed of characteristic layers formed by mid-ocean ridge (MOR) magmatic processes and subsequent sedimentation. The uppermost component is primarily composed of pelagic sediment but may also include terrigenous sediment if the oceanic crust is proximal to continental lithosphere and associated weathering and mass wasting processes. Beneath the sediments are basaltic pillow lavas and sheeted feeder dike complexes. The deepest portions of the oceanic plate are gabbros and peridotite.

Oceanic crust and the sedimentary veneer are hydrated and altered via reactions with seawater. The deposition of sediment onto the crust introduces additional pore and chemically bound water (Rüpke et al., 2004). The process of subduction induces prograde metamorphism of the slab, resulting in the release of hydrous fluids into the overlying peridotitic mantle wedge (figure 1.1). These hydrous phases may include low-density fluids and high density solute-rich fluids (Schmidt and 
Poli, 2003; Kessel et al., 2005; Timm et al., 2016). Fluid flow from the subducting plate to the overlying mantle wedge enables the transport of fluid-mobile elements, primarily large ion lithophile elements (LILE; e.g., $\mathrm{Rb}, \mathrm{Ba}, \mathrm{K}, \mathrm{Sr}, \mathrm{Pb}$ ). As a consequence, these elements are commonly enriched in arc lavas compared to mid ocean ridge lavas (e.g., Pearce and Stern, 2006). Slab dehydration at depth and fluid interaction with the overlying mantle results in the formation of a serpentinite layer above the subducting slab (figure 1.1), acting as an interstitial reservoir for hydrous fluids and associated slab derived elements. This serpentinite layer is subsequently dragged down due to slab pull and subarc mantle convection, heated, and dehydrated, releasing fluids into the overlying mantle. Initial serpentine dehydration at $\sim 100-170 \mathrm{~km}$ depth is believed to approximately underlie the location of arc volcanism on the surface (e.g., Hattori and Guillot, 2003; Rüpke et al., 2004; Wysoczanski et al., 2006; Deschamps and Hattori, 2013; Peters et al., 2017). Dehydration reactions depend critically on the thermal profile of the subduction zone; a colder slab or shallower geothermal gradient will act to delay dehydration to greater depths (e.g., Rüpke et al., 2004).

A wide variety of hydrous minerals are potentially stable in the subducting slab. Hydrous phases within the subducting basaltic crust that can break down and subsequently hydrate the overlying mantle include amphibole, lawsonite, zoisite, chloritoid, talc and phengite (Ryan and Chauvel, 2013). Importantly, some phases are stable beyond the arc front (e.g., phengite, topaz, and pumpellyite in metasediments can be stable up to $900^{\circ} \mathrm{C}$ and $7 \mathrm{GPa}$ ) thus, coupled with serpentinite movement, these phases are able to carry $\mathrm{H}_{2} \mathrm{O}$ and fluid mobile elements significantly past the arc front (e.g., Domanik and Holloway, 1996; Ono, 1998; Hattori and Guillot, 2003; Wysoczanski et al., 2006).

Dehydration is generally considered to be the dominant mechanism for transport of elements from slab to mantle in modern subduction regimes (Schmidt \& Poli, 2003). Another transport mechanism may be silicate melts, sourced from either subducting sediment or possibly mafic oceanic crust, with subsequent migration to, and bulk mixing with the overlying mantle (figure 1.1). The involvement of slab melt is supported by subduction zone thermal models and calculated P-T paths of subducting slabs that suggest the upper slab-mantle interface may reach temperatures sufficient for partial melting of the oceanic crustal rocks, particularly sediment (Abers et al., 
2006; Syracuse et al., 2010; Bebout, 2014). Furthermore, the addition of silicate melts to the mantle wedge is interpreted to be the primary reason for observed enrichment of light rare earth elements (LREE; significantly less fluid-mobile than LILE) in arc basalts relative to mid-ocean ridge basalts (MORB; Elliott, Plank, Zindler, White, \& Bourdon, 1997; Johnson \& Plank, 2000; Plank \& Langmuir, 1998).

At higher pressures (approximately $\geq 6 \mathrm{GPa}$ ) hydrous fluids and silicate melts converge into a single supercritical fluid phase (Kessel et al., 2005; figure 1.1). These supercritical fluids feature higher compatibilities for both LILE and rare earth elements (REE) than lower pressure fluids (Kessel et al., 2005). A supercritical phase would dominate at depths corresponding to back-arc regions, thus potentially being a key mode of transport for both LILE and REE in this setting (Kessel et al., 2005; Hermann et al., 2006; Manning, 2006; Ni et al., 2017).

Slab components released down the subducting slab and at the subduction front become increasingly complex by situational features, including the age and related thermal properties of the down going slab, as well as sediment components that may additionally have significant lateral variation (Plank, 1998, 2014; Singer et al., 2007). Also, fluid production varies as a result of continuous and discontinuous dehydration reactions from a vertical column featuring a thermal gradient (Schmidt and Poli, 2003).

\subsubsection{Partial melting of the mantle, crystal fractionation and crustal assimilation}

The transfer of hydrous fluid phases into the overlying mantle wedge instigates partial melting of the mantle by lowering the peridotite solidus to below ambient temperatures (e.g., Schmidt and Poli, 2014; Timm et al., 2016). The composition of the primary mantle melt generated is dependent on the composition of the mantle, the metasomatic processes that result from slab derived fluids, and the degree of partial melting (Pearce and Stern, 2006). Partial melts derived from the mantle are enriched in elements that are the most incompatible within the mantle mineral phases (e.g., olivine, pyroxene, and garnet). Melts are progressively less enriched in these elements as the degree of partial melting increases due to increased incorporation of more compatible components as mineral phases are completely melted and other more 
residual phases begin to melt. The degree of partial melting will exert a large control over the relative enrichment of base metals within a melt because, broadly, base metals are varyingly incompatible within typical mantle minerals (e.g., olivine, orthopyroxene, clinopyroxene, and spinel or garnet). The main exception being a slight compatibility of V within clinopyroxene (Bougault and Hekinian, 1974; Paster et al., 1974; Matsui et al., 1977; Kravuchuk et al., 1981; Klock and Palme, 1988; McKenzie and O’Nions, 1991; Hart and Dunn, 1993; Jenner et al., 1993; Hauri et al., 1994).

Primitive subduction zone magmas are generally hydrous basalts (Richards, 2003; Cooke et al., 2013). During ascent and storage in magma chambers these melts evolve through processes of crystal fractionation, magma mixing and crustal contamination. Significant mafic magma bodies may develop at the base of the crust if the crustal material is less dense than the magma. This process is termed 'underplating'. Accumulation of crystallizing magma causes the fractionation of more evolved magmas and notable heat production. This increased heat can facilitate partial melting and assimilation of lower crustal rocks. Together these processes lead to production of fractionated melts of basaltic andesitic to dacitic compositions (Hildreth and Moorbath, 1988; Richards, 2003). Both crystal fractionation and crustal assimilation will lead to relative increases of incompatible element concentrations within the magma; incompatible elements will be preferentially selected from the crust and more compatible elements incorporated within crystallizing minerals. The degree of compositional changes during these processes is dependent on the mineral phases present and the total amount of fractionation or assimilation.

\subsubsection{Magma Degassing}

Bulk chemical composition of magmas will also vary as a result of magma degassing; the loss of volatiles elements from the magma as it rises through the crust. Magma degasses when the volatile contents of the melt become oversaturated. Oversaturation can result from changing environmental conditions such as decreasing temperature or pressure, or via a relative increase in concentration of volatiles within the magma body, for example, through fractional crystallization. Crystallization of anhydrous minerals preferentially involves non-volatile phases, thus leading to a 
subsequent enrichment of volatiles within the remaining melt phase and potential oversaturation.

Magma degassing is an important control on magma composition. Degassing can cause fluid-mobile elements or species (e.g., $\mathrm{Ba}, \mathrm{Ca}, \mathrm{Rb}, \mathrm{Pb}, \mathrm{Sb}$ ) to be preferentially removed from the melt and transported with the volatile phase. Exsolved volatile phases are predominantly aqueous, but also include sulfur species, $\mathrm{CO}_{2}, \mathrm{NaCl}, \mathrm{KCl}, \mathrm{HCl}$, and metal chlorides (e.g., Richards, 2011).

Constraining the volatile contents of arc magmas and their degassing history is difficult given that volatiles are mostly lost via degassing during eruption. However, melt inclusions trapped within phenocrysts at depth provide valuable insights into preeruption volatile concentrations. These melt inclusions provide snapshots of the melt composition at earlier stages of magma evolution.

The most abundant volatile component in subduction zone settings is $\mathrm{H}_{2} \mathrm{O}$ (e.g., Ito et al., 1983). Water is expected to exsolve from hydrous magmas during ascent or eruption, driven by the decreasing solubility of water in silicate melts with decreasing pressure (Eichelberger, 2002; Richards, 2011). Melt inclusions from arc settings display a wide range of $\mathrm{H}_{2} \mathrm{O}$ concentrations; e.g., $5-6$ wt.\% in basalts from Nicaragua (Cerro Negro), central Mexico, to $<0.5$ wt.\% for Gulunggung, Indonesia (Wallace, 2005). Olivine hosted melt inclusions from the KAHT show $\mathrm{H}_{2} \mathrm{O}$ contents ranging between approximately $0.8-2.6$ wt.\% (Wysoczanski et al., 2012). Variations in $\mathrm{H}_{2} \mathrm{O}$ contents can be partially attributed to factors such as proximity to the arc front and degree of slab dehydration. Generally, $\mathrm{H}_{2} \mathrm{O}$ input into the mantle from subducting material decreases with distance from the trench, consistent with back-arc basalts typically displaying lower $\mathrm{H}_{2} \mathrm{O}$ concentrations (e.g., Lau Basin with $0.5-2$ wt.\% $\mathrm{H}_{2} \mathrm{O}$; Kent et al., 2002) than volcanic front basalts (e.g., Tonga arc with $3-5$ wt.\% $\mathrm{H}_{2} \mathrm{O}$; Cooper et al., 2006). Although back-arc lavas have lower $\mathrm{H}_{2} \mathrm{O}$ concentrations than arc front lavas, they have notably higher concentrations than mid-ocean ridge lavas ( $0.2-0.3 \mathrm{wt} . \%$; Walker et al., 2003; Kelley et al., 2006; de Ronde et al., 2007; Portnyagin et al., 2007; Gale et al., 2013).

Carbon dioxide contents in mineral-hosted melt range from $\sim 25 \mathrm{ppm}$ to $\sim 2500$ ppm (Wallace, 2005). Importantly, $\mathrm{CO}_{2}$ shows no systematic variations, contrasting 
other volatile components which is likely the result of early $\mathrm{CO}_{2}$ degassing before capture of the melt inclusion (e.g., Wallace, 2005). For example, olivine-hosted melt inclusions from the southern Kermadec Arc and Have Trough (SKAHT) have $\mathrm{CO}_{2}$ contents $(<250 \mathrm{ppm})$ greater than that of associated glassy groundmass, but notably less than those expected from undegassed arc front lavas (<3000 ppm; Wallace, 2005; Wysoczanski et al., 2006; 2012). This suggests that in arc settings, significant degassing of $\mathrm{CO}_{2}$ occurs prior to olivine crystallization. The early degassing of $\mathrm{CO}_{2}$ is caused by the much lower solubility of $\mathrm{CO}_{2}$ in silicate melts in comparison to other volatiles such as $\mathrm{H}_{2} \mathrm{O}$. Therefore, melts can lose significant quantities of $\mathrm{CO}_{2}$ with little impact on $\mathrm{H}_{2} \mathrm{O}$ concentration (figure 1.2; Dixon and Stolper, 1995; Newman and Lowenstern, 2002). Sources of carbon in arc magmas include carbonate and other organic material in marine sediments transported to the magma source as slab derived components as well as mantle derived carbon.

Figure 1.2: Degassing trends for $\mathrm{H}_{2} \mathrm{O}$ and $\mathrm{CO}_{2}$ for $1200^{\circ} \mathrm{C}$ basaltic (49 wt.\% $\mathrm{SiO}_{2}$ ) melt with 4 wt.\% $\mathrm{H}_{2} \mathrm{O}$ and 3000 ppm $\mathrm{CO}_{2}$. Sourced from Newman \& Lowenstern (2002).

Another key volatile species is sulfur. Sulfur is important as it is strongly linked to the mobility of chalcophile and siderophile elements (sulfide- and metal ironassociated elements, respectively). An absence of a sulfur-bearing phase and/or melt in the magma causes elements such as $\mathrm{Pb}, \mathrm{Sb}, \mathrm{Sn}, \mathrm{Ag}, \mathrm{Bi}, \mathrm{As}, \mathrm{Mo}$ and $\mathrm{TI}$ to generally behave incompatibly during magma evolution (Timm et al., 2012). Melt inclusions within minerals from basaltic arc magmas generally show higher sulfur concentrations ( 900-2500 ppm) than MORB at a given wt.\% $\mathrm{FeO}_{\text {total }}$ (Wallace, 2005), and greater 
than the estimated underlying arc mantle sulfur contents of $250-500 \mathrm{ppm}$ (Métrich et al., 1999; De Hoog et al., 2001). Sulfur solubility in magmas increases substantially with increasing oxygen fugacity $\left(f_{\mathrm{O}_{2}}\right)$, consistent with arc magmas having higher $f_{\mathrm{O}_{2}}$ values than other settings such as mid ocean ridges ( $~ 2 \log f_{O_{2}}$ units higher(e.g., Jugo, 2009; Richards, 2011). The higher $f_{\mathrm{O}_{2}}$ also transitions sulfur speciation from reduced $\mathrm{S}^{2-}$ to oxidised $\mathrm{S}^{6+}$ (Carroll and Rutherford, 1988; Luhr, 1990). Arc dacitic and rhyolitic magmas are commonly sulfide-saturated as indicated by the presence of pyrrhotite, chalcopyrite, monosulfides, and associated solid solutions. At higher oxygen fugacity conditions (MNH redox buffer) with sulfate being the primary species, anhydrite can also fractionate (Carroll and Rutherford, 1988; Luhr, 1990). The onset of magnetite fractionation (approximately $\geq 55 \mathrm{wt} \% \mathrm{SiO}_{2}$ ) coincides with decreases in $\mathrm{SO}_{4} / \mathrm{S}^{2-}$, eventually triggering sulfide saturation and the crystallisation of sulfide minerals (e.g., bornite) which remove sulfur and some metals (e.g., $\mathrm{Ag}, \mathrm{Au}, \mathrm{Cu}$ ) from the magma. This is termed the magnetite crisis after Jenner et al. (2010).

Chlorine in arc settings is particularly important because the solubility of many elements in high-T aqueous fluids are partially controlled by $\mathrm{Cl}$ (Wallace, 2005). Chlorine concentrations in basaltic arc melt inclusions are typically between 500 and 2000 ppm, and like sulfur, are higher than in MORB samples ( 50 - 300 ppm; Jambon et al., 1995). This suggests that $\mathrm{Cl}$ is recycled from the subducting slab which has accumulated $\mathrm{Cl}$ via hydration reactions with seawater (Schilling et al., 1978; Ito et al., 1983). Subduction related enrichment of $\mathrm{Cl}$ is supported by correlations observed between $\mathrm{Cl}$ contents and enrichment in LILE (e.g., Yb) attributed to slab derived aqueous fluids (e.g., Wysoczanski et al., 2006). High lava chlorine content suggests that the underlying mantle melting zone has undergone $\mathrm{Cl}$ addition via fluids derived from the subducting crust (e.g., Kent and Elliott, 2002). Melt inclusion data indicate $\mathrm{Cl}$ within the mantle wedge would have to be partitioned between the melt and a $\mathrm{H}_{2} \mathrm{O}-\mathrm{CO}_{2}-\mathrm{Cl}-\mathrm{S}$ vapour phase as common arc P-T conditions are not sufficient for a hydrosaline melt (Webster et al., 1999; Wallace, 2005). 


\subsection{Melt inclusions}

Melt inclusions form within crystals where the crystal lattice growth is perturbed by a range of possible factors, such as lack of nutrients or strong undercooling (Lowenstern, 1995; Wallace, 2005). As such, they can be utilised to obtain pre-eruption and earlier stage melt compositions (e.g., Luhr, 2001; Kent and Elliott, 2002; Wallace, 2005; Rowe et al., 2007; Maclennan, 2008; Wallace and Edmonds, 2011; Wysoczanski et al., 2012). This is predicated on the assumption that their composition is representative of the bulk melt at the time of trapping within the crystal. However, it is apparent that the composition of melt inclusions may be impacted by later processes, such as devitrification, crystallisation, or fracturing. All of which may affect the bulk composition and elemental distribution within the inclusion (Frezzotti, 2001). Therefore, suitable 'pristine' melt inclusions can be selected by an absence of daughter crystals (e.g., microlites), strong discolouration, and fracturing. A less apparent complication may arise due to diffusion, potentially creating boundary layer enrichment or depletion (Roedder, 1984; Wallace, 2005). Lu et al. (1995) studied rhyolitic melt inclusions from the Bishop Tuff incorporating diffusion theory, demonstrating that compositional gradients from boundary effects have negligible impacts on the compositions for melt inclusions with a diameter greater than $50 \mu \mathrm{m}$. A non-negligible effect may occur in smaller inclusions $(<50 \mu \mathrm{m}$ in diameter) and should be considered during interpretation.

\subsection{Volcanogenic Massive Sulfide deposits and base metals in arc settings}

A need for understanding the budget and behaviour of metals in a subduction zone - magmatic arc setting is due to their association metal-rich VMS deposits. VMS deposits are the result of hydrothermal convection of seawater through crustal rocks, driven by crustal heat flow primarily from molten or recently crystallized magma bodies (figure 1.3). These deposits accumulate on the seabed through instant cooling and precipitation of metals dissolved in hydrothermal fluids expelled at temperatures of $250-350^{\circ} \mathrm{C}$ (figure 1.3; Hannington, 2014). As a consequence VMS deposits are of notable economic interest due to hosting significant proportions of chalcophile and 
siderophile elements (e.g., $\mathrm{Cu}, \mathrm{Au}, \mathrm{V}, \mathrm{Zn}, \mathrm{Sb}, \mathrm{Bi}$, and $\mathrm{As}$ ), which are derived from underlying volcanic rocks (e.g., Timm et al., 2012).

Heat flow draws down cold seawater towards the top of a magma body whereby it is heated and driven back to the seafloor due to buoyancy. Seawater transport favourably occurs along faults and fissures such as those present in regions of rifting, allowing infiltration to several kilometres crustal depth (figure 1.3; Hannington, 2014). Reactions between the seawater and the volcanic rocks above the heat source take place along the entire flow path, from low to high temperatures, although most readily at the point of highest temperature. These reactions leach metals from the rock overlying the heat source and are primarily transported as chloride complexes (figure 1.3; Hannington, 2014). Iron, $\mathrm{Mn}, \mathrm{Zn}$, and $\mathrm{Cu}$ are mainly sourced from primary sulfides and ferromagnesian minerals whereas $\mathrm{Pb}$ and $\mathrm{Ba}$ are sourced from the dissolution of feldspars (e.g., Doe, 1994). Upon the release of hydrothermal fluids onto the seafloor, sulfide mineral precipitation occurs in response to cooling, $\mathrm{pH}$ changes and oxidation associated with reactions with seawater, forming VMS deposits.

The trace metal composition of VMS deposits appears to strongly correlate with that of the underlying volcanic/crustal rocks through which the hydrothermal fluids flowed (Hannington, 2014). The host rocks can undergo prior fluid-rock alteration due to inflowing of exsolved magmatic fluids/volatiles (e.g., those discussed in section 1.2.3). These exsolved magmatic fluids cause the formation of porphyry deposits within the host rocks. As fluids cool during ascent, sulfide species' solubility decreases, dramatically between $\sim 400^{\circ}-300^{\circ} \mathrm{C}$, likely corresponding to depths within approximately $1-2 \mathrm{~km}$ of the surface (Landtwing et al., 2005; Richards, 2011). Furthermore, $\mathrm{SO}_{2}$ dissociation to $\mathrm{H}_{2} \mathrm{~S}$ and $\mathrm{H}_{2} \mathrm{SO}_{4}$ at temperatures below $\sim 400^{\circ} \mathrm{C}$ initiates precipitation of sulfide minerals (Kusakabe et al., 2000; Richards, 2011). Therefore, the source rocks of VMS deposit may have been variably enriched in trace metals by the formation of porphyry deposits. 
Figure 1.3: Schematic model of a typical submarine hydrothermal system and schematic cross-section of a typical volcanogenic massive sulfide deposit (inset). Main features include, hydrothermal flow, reaction and discharge zones, and smaller scale hydrothermal upflow and seafloor sulfide deposits. Adapted from Hannington (2014).

A concern when studying VMS deposits is understanding the reservoirs and sources of associated chalcophile and siderophile elements. Arc magmas commonly display higher concentrations of $\mathrm{Ag}, \mathrm{Au}, \mathrm{Cu}, \mathrm{Mo}, \mathrm{Bi}, \mathrm{Zn}, \mathrm{V}, \mathrm{Sb}, \mathrm{As}, \mathrm{Pb}$, and sulfur relative to MORB (Jochum and Verma, 1996; Noll et al., 1996; De Hoog et al., 2001; Jenner et al., 2010; Richards, 2011). This enrichment is likely due to the addition of hydrous fluids or partial melts from the subducting slab (Elliott et al., 1997; De Hoog et al., 2001) and/or increased liberation of chalcophile and siderophile elements within the mantle wedge (Mungall, 2002).

Chalcophile elements such as $\mathrm{Pb}, \mathrm{Sb}, \mathrm{As}$ and $\mathrm{Tl}$ (as well as non-chalcophile elements; $\mathrm{Ba}, \mathrm{Ca}, \mathrm{Rb}, \mathrm{U}, \mathrm{K}$, and $\mathrm{Sr}$ ) are highly fluid-soluble and mobile during slab dehydration (Stolper and Newman, 1994; Elliott et al., 1997; Plank and Langmuir, 1998; Rüpke et al., 2004; Spandler et al., 2004). Copper and Au are mobile during dehydration of altered oceanic crust, especially in the presence of $\mathrm{Cl}$ or sulfur (Hamlyn et al., 1985; Noll et al., 1996). Lead can be primarily derived from fluids released from altered oceanic crust (e.g., Tafahi and Niuatoputapu, northern Tonga arc; Regelous, Gamble, \& Turner, 2010) or subducted sediment (e.g., southern Kermadec Arc; Gamble et al., 1996; Haase et al., 2002; Regelous et al., 2010) or both (e.g., Wysoczanski et al., 2006). Molybdenum, Sn, and $W$ are less mobile but thought to be derived from the subducting slab (Noll et al., 1996). Increased liberation of metals from the mantle wedge is related to more oxidising conditions with increasing $f_{\mathrm{O}_{2}}$ introduced with the influx of slab-derived aqueous fluids (Timm et al., 2012). This is perhaps most clearly 
shown by the behaviour of $\mathrm{V}$, which becomes increasingly incompatible during partial melting of the mantle at high $f_{\mathrm{O}_{2}}$ (e.g., Lee et al., 2003)

Arc magmas are generally up to $2 \log f_{O_{2}}$ above the fayalite-magnetite-quartz (FMQ) mineral redox buffer where sulfur is present as $\mathrm{SO}_{4}{ }^{2-}$ (Mungall, 2002). The high $f_{\mathrm{O}_{2}}$ allows the magma to retain chalcophile elements during fractional crystallization of olivine, pyroxene, and plagioclase (Timm et al., 2012). As arc magmas evolve, some chalcophile and siderophile elements (e.g., $\mathrm{Cu}, \mathrm{Zn}, \mathrm{Au}, \mathrm{Ag}, \mathrm{V}$ and $\mathrm{Mn}$ ) may begin to decrease in concentration at and beyond $\sim 55 \mathrm{wt} . \% \mathrm{SiO}_{2}$. This corresponds to the crystallization of Fe-Ti oxides, which can trigger sulfide saturation and associated sulfide mineral growth in which these elements are compatible (Jenner et al., 2010).

\subsection{This study}

This research aims to better constrain the movement of elements, particularly base metals, through the arc magmatic system, from melting of subarc mantle through to eruption at the southern Kermadec Arc - Havre Trough subduction system. To do so, major element compositions have been measured using an electron probe microanalyser (EPMA), volatile elements via Fourier-transform infrared spectroscopy (FTIR) and trace elements with laser ablation inductively coupled mass spectrometry (LA-ICPMS) of both glassy groundmass material of pillow rim glasses and olivine hosted melt inclusions. Coupling glassy groundmass and olivine hosted melt inclusions allows for both the comparison between evolved and relatively primitive melt compositions, and the effects of different arc processes on these compositions to be constrained. Here I used melt inclusions found in olivine from the quenched glassy rims of arc front and back-arc lavas to reduce the effects of inclusion crystallisation and devitrification.

This research also compares the chemical composition of melt inclusion and glassy groundmass from several SKAHT arc/back-arc lavas from different locations. Sample locations extend from the arc front volcanic centres (Rumble II West \& Rumble III) to the nearby Havre Trough back-arc, with sampling from basins D and I (table 1.1; figure 1.4). The sampling pattern was designed to investigate spatial variability in compositions between arc front and back-arc melts. Although back-arc samples in the Havre Trough are distant from the subduction boundary $(\sim 200-300 \mathrm{~km})$, it is likely 
they have also been influenced by slab-derived components (e.g., Pearce and Peate, 1995; Bach et al., 1998; Peate et al., 2001; Haase et al., 2002; Todd et al., 2010, 2011).

Constraining elemental abundances and behaviour associated with the evolution of arc magmas is particularly pertinent to the behaviour of volatiles and associated base metals that feed VMS deposits. Quantifying base metal (e.g., Cu, Zn, $\mathrm{Pb}$ etc.) and volatile (e.g., $\mathrm{S}, \mathrm{Cl}, \mathrm{CO}_{2}, \mathrm{H}_{2} \mathrm{O}$ ) movement from the mantle wedge to the surface can be improved through the analysis of melt inclusions and groundmass glass.

Table 1.0-1: Arc front stratovolcano and back-arc basin samples investigated in this study.

\begin{tabular}{|c|c|c|c|c|c|c|c|}
\hline Station & $\begin{array}{l}\text { Sample } \\
\text { Number }\end{array}$ & Location & Latitude & Longitude & $\begin{array}{l}\text { Depth } \\
\text { (Mbsl) } \\
\end{array}$ & $\begin{array}{c}\text { In text } \\
\text { reference }\end{array}$ & $\begin{array}{c}\text { Reference } \\
\text { symbol }\end{array}$ \\
\hline $\begin{array}{l}\text { TAN1104- } \\
\text { ES11C }\end{array}$ & C & $\begin{array}{c}\text { RII West SW } \\
\text { Caldera }\end{array}$ & $35.360 \mathrm{~S}$ & $178.509 \mathrm{E}$ & $\begin{array}{c}1440- \\
1425\end{array}$ & RIIW-1 & \\
\hline $\begin{array}{l}\text { TAN1104- } \\
\text { ES16 }\end{array}$ & B & $\begin{array}{c}\text { RII West } \\
\text { Ridge to SE } \\
\text { Caldera }\end{array}$ & $35.352 \mathrm{~S}$ & $178.529 \mathrm{E}$ & $\begin{array}{c}1452- \\
1165\end{array}$ & RIIW-2 & \\
\hline $\begin{array}{l}\text { TAN1104- } \\
\text { ES30 }\end{array}$ & C & $\begin{array}{c}\text { RII West } \\
\text { Ridge to SE } \\
\text { Caldera }\end{array}$ & $35.353 \mathrm{~S}$ & $178.537 \mathrm{E}$ & 1306 & RIIW-3 & \\
\hline TAN1513-040 & 1 & Basin I & $35.3166 \mathrm{~S}$ & $177.739 \mathrm{E}$ & 2182 & Basin I & \\
\hline TAN1213-51 & 6 & Basin D & $35.39 \mathrm{~S}$ & $178.228 \mathrm{E}$ & 2840 & Basin D & \\
\hline TAN1104-53 & A & Rumble III & $35.743 \mathrm{~S}$ & $178.506 \mathrm{E}$ & 275 & RIII-1 & \\
\hline TAN1104-55 & B & Rumble III & $35.743 \mathrm{~S}$ & $178.506 \mathrm{E}$ & 254 & RIII-2 & \\
\hline
\end{tabular}




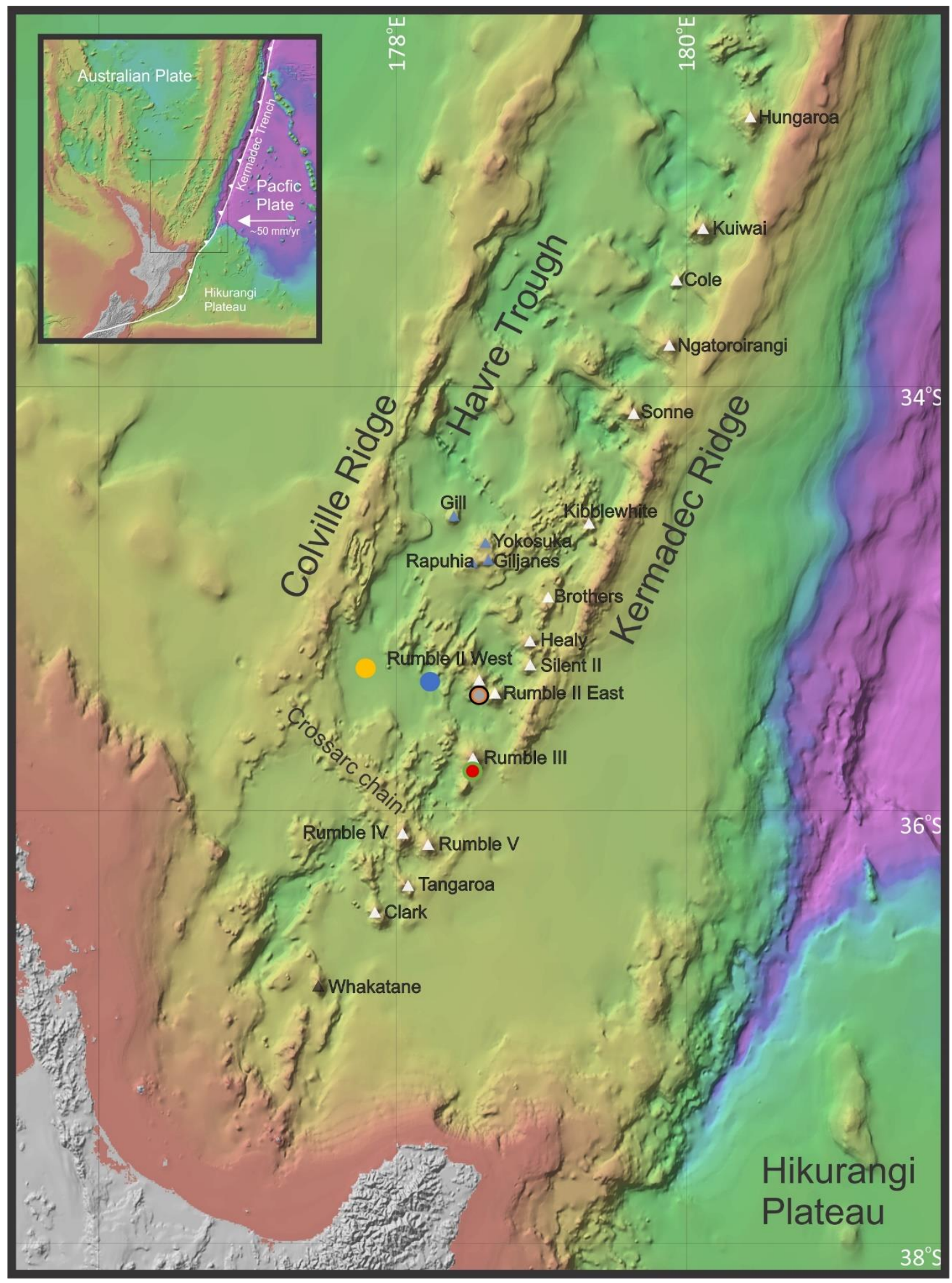

Figure 1.4: Regional map of the southern Kermadec Arc-Havre Trough (stylised after Wysoczanski et al., 2012) showing primary features referred to in text. Inset shows the position of the Kermadec Arc-Havre Trough to continental New Zealand, Pacific and Australian plates and Kermadec trench. Black square within inset shows the extent of the main map. White Triangles in main map represent Kermadec arc volcanic centres, blue triangles represent back-arc stratovolcanoes mentioned in text. Black triangles are stratovolcanoes of the Taupo Volcanic zone (only Whakatane shown). General sample locations are denoted by symbols and colours related to those used on element plots. Rumble II West and Rumble III symbols are offset from true location as to not obscure the respective edifices. Base bathymetric map courtesy of NIWA (downloaded from https://www.niwa.co.nz/our-science/oceans/bathymetry/download-the-data?sid=15661). 


\subsection{Thesis Objectives and Outline}

The primary objective of this thesis was to investigate the metal budget of magmas generated within the southern Kermadec Arc volcanoes, Rumble II West and Rumble III and nearby Havre Trough back-arc. To this end, an arc-back-arc transect of chemical compositions derived from volcanic glasses and olivine-hosted melt inclusions has been carried out. Major, trace and volatile element data from selected samples are used to evaluate composition trends between relatively primitive and evolved melts, and their spatial variation, with the aim of addressing several key questions pertaining to elemental recycling (specifically metals) within an arc - backarc setting.

1. How do primary melt compositions vary spatially between sample locations? This involves investigating the roles mantle fertility, degrees of partial melting, and subduction related mantle enrichment.

2. How do compositions vary between relatively primitive and evolved melts within the SKAHT lavas with particular focus on the behaviour of metals during magma evolution involving crystal fractionation and volatile degassing?

3. How do compositional trends vary between arc front and back-arc samples?

4. Can explanations for variable metal element enrichment, and volatile element behaviours be related to the formation, or promotion of VMS deposits, i.e. what factors contribute the most to high metal element abundances within melts and their potential transport within volatile phases?

The analytical techniques that have been used in this study include:

- Volatile element compositional analysis on both glass and olivine-hosted melt inclusions using an electron probe micro-analyser (EPMA) for sulfur and chlorine, and Fourier transform infrared spectroscopy (FTIR) for $\mathrm{H}_{2} \mathrm{O}, \mathrm{OH}^{-}, \mathrm{CO}_{2}$ and $\mathrm{CO}_{3}$.

- Glass and olivine-hosted melt inclusion major element analysis using the EPMA, and trace element analysis using laser ablation inductively coupled plasma - mass spectrometry (LA-ICPMS). 


\subsection{Thesis structure}

Chapter 1. Introduction:

An overview of subduction zones and their geochemical and physical aspects relating to magma composition and arc volcanism, a brief introduction to VMS deposits and their relationships to magma composition, as well as objectives of the thesis.

Chapter 2. Geological setting:

A background to the Kermadec Arc - Havre Trough and the subduction setting, their chemical and physical aspects with a primary focus on the southern Kermadec Arc. Descriptions of sample sites (Rumble II West, Rumble III, Basin $\mathrm{D}$, and Basin I) are also given.

Chapter 3. Analytical Techniques:

A description of methods used to obtain element data used in this thesis as well as data processing methods.

Chapter 4. Results:

The key results of this research, including compositional trends of major, volatile, and trace elements.

Chapter 5. Discussion:

Interpretation of the results, how they relate to the geochemical and geophysical processes within a subduction-arc setting.

Chapter 6. Conclusions:

A summary of key findings and recommendations for future work.

\section{References:}

A list of all reference sources cited in this thesis. The reference style used follows that of the Journal of Petrology. 
Appendices:

Additional data tables including unprocessed and processed melt inclusion, host olivine, and groundmass glass compositions (major and trace). 
Chapter 2: Geological Setting 


\subsection{Overview of the Kermadec Arc-Havre Trough back-arc system and subduction}

setting

The KAHT is an intra-oceanic arc and back-arc system situated to the north-east of North Island, New Zealand (figure 2.1). At $\sim 25^{\circ} 36^{\prime}$ the SKAHT transitions into the Tonga arc - Lau Basin back-arc together extending $\sim 2500 \mathrm{~km}$ between New Zealand and Samoa. The separation of the two contiguous arcs is marked by the intersection and subduction of the Louisville seamount chain (figure 2.1; e.g., Koppers et al., 2004; Timm et al., 2013). To the south-west, the Kermadec Arc transitions into the continental Taupo Volcanic Zone, New Zealand, with margins that have remained relatively constant for the past 0.7 Myr (Wilson et al., 1995; Bernal et al., 2014). The Taupo - Kermadec - Tonga arc system is the result of collision between the Pacific and Australian plates whereby the relatively cold and old (>80 Ma) Pacific plate is being subducted beneath the Australian plate (figure 2.1; Wright et al., 2006). This convergent boundary additionally involves the Niuafo'ou, Tonga, and Kermadec microplates, accommodating the rifting and spreading occurring in both the Lau Basin and Havre Trough (Pelletier and Louat, 1989; Zellmer and Taylor, 2001; Bird, 2003; Ruellan et al., 2003; Wright et al., 2006).

Subduction rates along the Tonga-Kermadec Arc system vary linearly with latitude, with a maximum of $\sim 24 \mathrm{~cm} \mathrm{a}^{-1}$ along the northern portion of the Tonga arc, denoting a global maximum, to $\sim 5 \mathrm{~cm}^{-1}$ along the southern Kermadec Arc (DeMets et al., 1994; Bevis et al., 1995). The Havre Trough and Lau back-arc basins are experiencing extension at rates of $\leq 1 \mathrm{~cm} \mathrm{a}^{-1}$ and $\sim 15.8 \mathrm{~cm} \mathrm{a}^{-1}$, respectively (Taylor et al., 1996; Schellart and Spakman, 2012), accommodated by spreading in the Lau Basin and possible extensional rifting in the Havre Trough (Wright et al., 1996). However, Wysoczanski et al. (2010) have suggested the Havre Trough is a site of new crustal growth, described as nascent 'disorganized' spreading as evident by $>4,000 \mathrm{~m}$ deep basins with axial ridges representative of magmatic activity. 


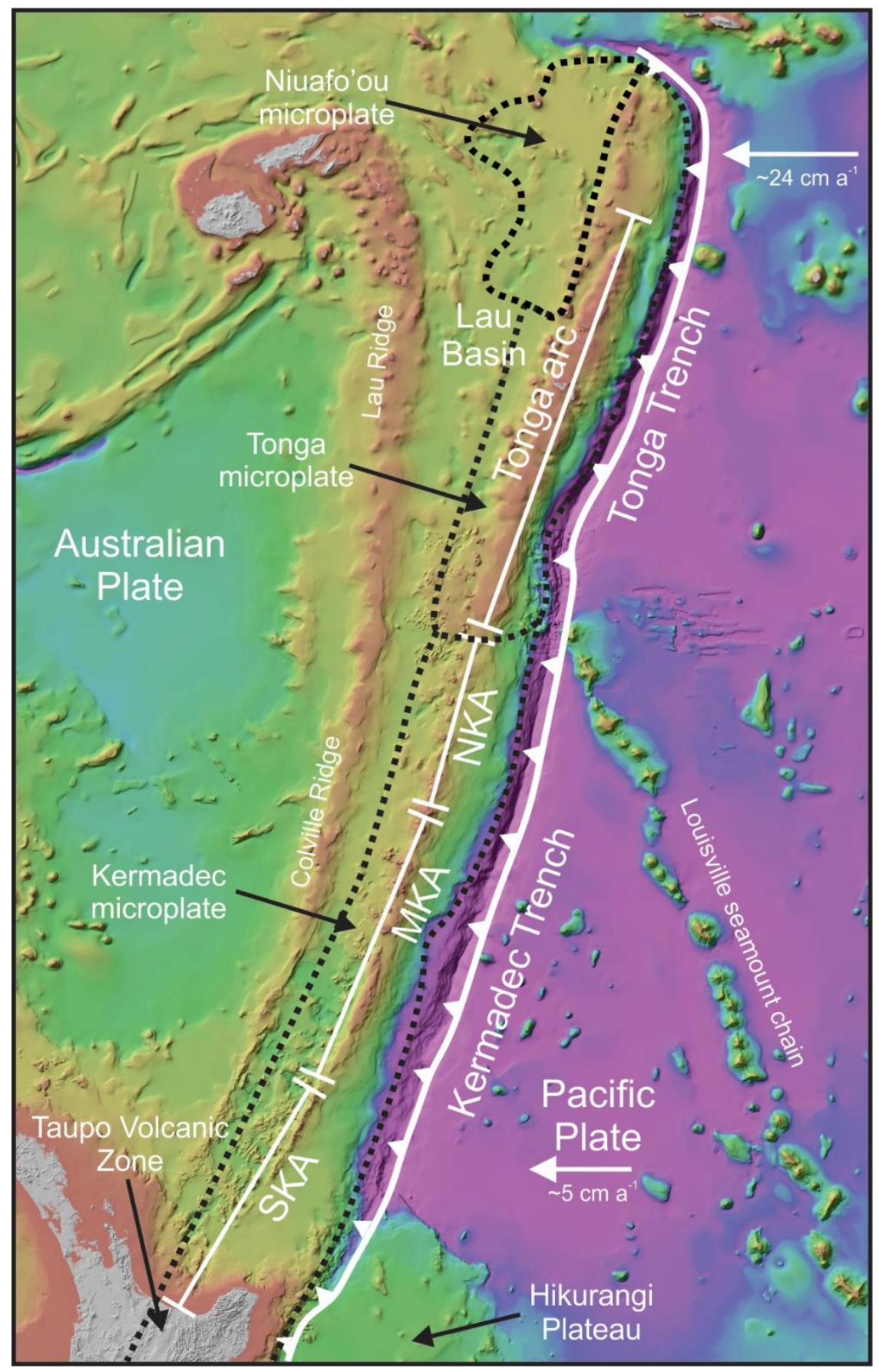

Figure 2.1: Regional bathymetric map of the Kermadec - Tonga Arc, Havre Trough - Lau Basin back-arc showing primary features referred to in text; The Pacific and Australian plates (with the subduction boundary along the Kermadec and Tonga Trench), as well as the approximate extents of the Kermadec, Tonga, and Niuafo'ou microplates (dashed black lines; Bird, (2003). The Southern Kermadec Arc (SKA), Middle Kermadec Arc (MKA; de Ronde et al., 2007), and Northern Kermadec Arc segments are also delineated by the white line markers. The Louisville seamount chain and Hikurangi Plateau are also shown. Base bathymetric map courtesy of NIWA (downloaded from https://www.niwa.co.nz/our-science/oceans/bathymetry/download-the-data?sid=15661). 
A notable feature of the KAHT region is the now inactive Lau-Colville Ridge west of the back-arc region (figure 2.1;Timm et al., In review). This ridge represents a remnant arc inactive due to trench roll-back and variable subduction rates that resulted in a clockwise rotation of the trench (Gamble \& Wright, 1995). The Colville Ridge, active from ca. $17 \mathrm{Ma}$ (Mortimer et al., 2010) to ca. 2.6 Ma (Timm et al., In review), and the subparallel Kermadec Ridge to the east (figure 2.1) active until at least $4 \mathrm{Ma}$ (Timm et al., In review), are remnants of the Colville volcanic arc, split by the development of the Havre Trough rift system. The timing of separation is contentious and is thought to be either ca. 5 Ma ((Wright, 1993; Parson and Wright, 1996) or ca. 2 Ma (Malahoff et al., 1982).

Subduction angles vary latitudinally along the Kermadec subduction front and additionally with depth. The subduction angle beneath the southern Tonga/northern Kermadec Arcs changes from $\sim 28^{\circ}$ at $60 \mathrm{~km}$ depth to $\sim 47^{\circ}$ at $100 \mathrm{~km}$ depth (Isacks and Barazangi, 1977; Bassett et al., 2016). A similar subduction angle increase from $\sim 20^{\circ}$ at $60 \mathrm{~km}$ depth to $\sim 56^{\circ}$ at $100 \mathrm{~km}$ depth is present in the southern Kermadec Arc (Bassett et al., 2010). The steepening of the upper portion of the subducting slab towards the north corresponds to a decrease in distance from the Kermadec Ridge to trench, from $\sim 300 \mathrm{~km}$ at $37^{\circ} \mathrm{S}$ to $\sim 185 \mathrm{~km}$ at $32^{\circ} \mathrm{S}$ (Wright, 1997).

Sediment cover composition and thickness of the subducting Pacific plate also varies with latitude, with $\sim 200 \mathrm{~m}$ of pelagic sediment at $\sim 25^{\circ} \mathrm{S}$ (southern Tonga arc; Turner et al., 1997) to $\sim 1 \mathrm{~km}$ of primarily terrigenous sediment along the southern Kermadec Arc, consistent with closer proximity to the New Zealand landmass and the Hikurangi fan drift (Carter et al., 1996; Ewart et al., 1998).

The Hikurangi Plateau is currently subducting beneath the southernmost Kermadec Arc (south of $\sim 35^{\circ}$ S) and North Island of New Zealand (Davy et al., 2008; Reyners et al., 2011; Timm et al., 2014, 2016). The plateau is a large igneous province (LIP), formed ca. $120 \mathrm{Ma}$ (Hoernle et al., 2010) as a part of the Ontong Java Plateau (e.g., Neal et al., 1997). The crustal thickness of the plateau is estimated to be $10-15$ $\mathrm{km}$ thick (Davy and Wood, 1994) and is overlain by $\sim 2 \mathrm{~km}$ thick sediment deposits (Wood and Davy, 1994). 


\subsection{Southern Kermadec Arc - Havre Trough Magmatism and Volcanism}

The Kermadec Arc is dominated by submarine volcanoes; the only exceptions being Raoul, Macauley, Curtis and L'Esperance between $\sim 29^{\circ}$ and $31^{\circ} \mathrm{S}$. Volcanic edifices of the Southern Kermadec Arc consists of stratovolcanoes and caldera complexes (Wright et al., 1996; Wright, 1997). De Ronde et al. (2007) separates and defines three components of the Kermadec Arc; northern Kermadec Arc (NKA), middle Kermadec Arc (MKA), and the southern Kermadec Arc (SKA; figure 2.1). These are divided on the basis of bathymetric data along the arc (Wright et al., 2006). The SKA includes all volcanic centres south of Sonne volcano to, but not including, Whakatane on the continental margin of New Zealand $(\sim 360 \mathrm{~km})$. The MKA extends from $34.1^{\circ} \mathrm{S}$ (between Kibblewhite and Sonne volcanoes) northwards to Raoul Island ( 590 km). For a total length of $1,335 \mathrm{~km}$, the NKA encompasses all volcanic centres NE of Raoul Island to the Monowai volcanic centre (De Ronde et al., 2007; figure 2.1).

Within the SKA, active volcanism is bounded to the east and west by the Kermadec and Colville Ridges, respectively, and generally offset westward from the Kermadec Ridge (figure 2.1). This contrasts with volcanic centres of the MKA which are located along the Kermadec Ridge. The SKA includes 12 volcanic centres, of which eight are currently hydrothermally active (Kibblewhite, Brothers, Healy, Rumble II West, Rumble III, Rumble V, Tangaroa, Clark). Brothers, Rumble II West, Clark and Haungaroa volcanic centres are currently the only volcanoes along the Kermadec Arc known to host hydrothermal mineralization (de Ronde et al., 2005, 2014; Leybourne et al., 2012). Brothers hosts the greatest $\mathrm{Cu}-\mathrm{Au}-\mathrm{Ag}$-rich mineral deposit found to date with up to $90 \mathrm{ppm} \mathrm{Au} \mathrm{(de} \mathrm{Ronde} \mathrm{et} \mathrm{al.,} \mathrm{2005).} \mathrm{In} \mathrm{contrast} \mathrm{to} \mathrm{the} \mathrm{arc} \mathrm{front,} \mathrm{no} \mathrm{high}$ temperature hydrothermal activity has been observed within the Havre Trough, despite comprising the majority area of the KAHT system. However, this discrepancy may be attributable to limited exploration of the Havre Trough (Wysoczanski et al., 2012).

Kermadec Arc volcanism is primarily basaltic-andesitic in composition ( 48 53 wt.\% $\mathrm{SiO}_{2}$; Gamble et al., 1990, 1993a, 1993b, 1997; figure 2.2). However, silicic volcanism becomes significant along segments with thicker arc crust (Smith et al., 2003; Wright et al., 2006; Barker et al., 2013). Silicic volcanism has been calculated to equate to approximately 30 vol.\% of eruptives south of $30^{\circ} \mathrm{S}$ along the Kermadec Arc 
( $800 \mathrm{~km}^{3}$; Wright et al., 2006). Wright et al. (2006) noted that a deeper central segment of the Kermadec $\operatorname{Arc}\left(>3200\right.$ m water-depth) between $32^{\circ} 20^{\prime}-34^{\circ} 10^{\prime} \mathrm{S}$ displays simple basalt-basaltic andesite stratovolcanoes. Adjacent, higher ( $<2500 \mathrm{~m}$ water depth) arc segments feature multi-vent caldera complexes that erupt dacite and basalt-basaltic andesite. These observations suggest that shallower segments correspond to thicker crust where magmas can stall for longer and/or anatexis can occur, driving magmas to more silicic compositions. A thicker crust hinders magma ascent, also promoting underplating and stagnation of magmas (Wright et al., 2006). Furthermore, shallower edifices are characterised by volatile rich magmas which when coupled with a reduced hydrostatic load allows for magma vesiculation, and fragmentation associated with pyroclastic eruptions (Wright et al., 2006). Most basaltic volcanoes of the SKA shoal to $<1000 \mathrm{~m}$ water depth, and display similar textural transitions, namely from effusive pillow lavas, massive flows, pillow and talus breccia to fragmented/scoriaceous hyaloclastite-pyroclastic deposits (Wright et al., 1996, $2002,2006)$. Havre Trough samples range from basalt to andesite, similar to the Kermadec Arc, but have distinctly higher alkali contents (<4.2 wt.\% at 50 wt.\% $\mathrm{SiO}_{2}$; Gamble et al., 1993; figure 2.2).

Figure 2.2: Silica vs. total alkalis for Kermadec Arc lavas. Classification fields from Le Maitre et al. (2002). Sourced from Timm et al. (2012). BAB field represents southern Lau Basin and Havre Trough basalts. Data collected partly from (marked by asterisk in legend) Turner et al. (1997; Ewart et al. (1998); Haase et al. (2002, 2006); Smith et al. (2009); Todd et al. (2011). For Monowai and Brothers, coloured and white/grey symbols represent data from Timm et al. (2012) and previous literature data, respectively. 
The Havre Trough back-arc features accretion of new oceanic crust by volcanism concentrated along disorganized short-segment spreading ridges (Wysoczanski et al., 2010). Major segments are associated with arc-perpendicular chains of constructional edifices (cross chains; Tamura et al., 2002; Todd et al., 2010; Wysoczanski et al., 2010). The most developed cross chain of the Havre Trough is the Rumble V Ridge ( $\left.\sim 36^{\circ} \mathrm{S}\right)$, extending from Rumble $V$ and Rumble IV arc front volcanoes to the Colville Ridge (Wright et al., 1996; Todd et al., 2010). Other prominent back-arc volcanic edifices include Gill, Rapuhia, Yokosuka, and Giljanes volcanoes (figure 2.1).

As with other intraoceanic arc lavas, those from the Kermadec Arc are characterised by a depletion of HFSE and enrichment of LILE (e.g., $\mathrm{Ba}$, Rb, K) relative to MORB (e.g., Gamble, Smith, et al., 1993; Timm et al., 2012; Wysoczanski et al., 2012). This is consistent with these lavas being derived from a depleted MORB-like source metasomatized by slab-derived fluid. Back-arc lavas from the Havre Trough display evidence of slab-derived contributions, although they are notably less enriched in fluid mobile elements than the arc front (Todd et al., 2010). Generally, subduction-mobile elements (including hydrous fluid and melt mobile elements) appear to decrease in abundance across-arc from the arc front to the back-arc basins, as noted in KAHT lavas (e.g., Todd et al., 2011; Timm et al., 2012; Wysoczanski et al., 2012). This observation has been associated with the progressive depletion of these elemental components from the subducting slab with depth (Leeman et al., 1990; Ryan et al., 1995; Walker et al., 2000, 2003, 2009; Ryan and Chauvel, 2013). Therefore, the mantle beneath the KAHT is expected to progressively feature less enrichment of mobile elements with increasing instance from the trend, a trend that is broadly consistent in trace element analyses of KAHT lavas (e.g., Todd et al., 2011; Timm et al., 2012; Wysoczanski et al., 2012).

\subsection{KAHT Mantle Source}

The composition of the mantle wedge underlying the KAHT, prior to metasomatic alteration by slab-derived components is believed to be similar to depleted MORB mantle (DMM; Haase et al., 2002). The isotopic composition of the back-arc lavas is broadly consistent with Pacific-type MORB $\left({ }^{87} \mathrm{Sr} /{ }^{86} \mathrm{Sr} \sim 0.7026\right.$, 
${ }^{143} \mathrm{Nd} /{ }^{144} \mathrm{Nd} \sim 0.51311,{ }^{206} \mathrm{~Pb} /{ }^{204} \mathrm{~Pb} \sim 18.7$; Haase et al., 2002). However, isotopic composition varies with latitude along the arc system (Haase et al., 2002; Timm et al., 2014). Chemical analysis and associated modelling suggest that the compositions of KAHT lavas formed from 5-15\% partial melting of the mantle source beneath the arc and back-arc (Woodhead et al., 1993; Ewart et al., 1998; Haase et al., 2002). The extent of source depletion, observed as low contents of fluid immobile trace elements, also varies with latitude, increasing northwards along the arc (Haase et al., 2002). This has been broadly correlated to the southward decrease in back arc basin spreading/rifting rates (Turner et al., 1997) as well as a southward-propagating backarc basin opening (Gamble et al., 1993). Haase et al. (2002) argue that the greater depletion of the northern arc mantle is due to another process. They identified that despite the change in extension rates between the central Lau Basin $\left(13 \mathrm{~cm} \mathrm{a}^{-1}\right.$ full rate at $19^{\circ} \mathrm{S}$ ) and the Havre Trough ( $\sim 2 \mathrm{~cm} \mathrm{a}^{-1}$ full rate at $\left.30^{\circ} \mathrm{S}\right)$, fluid-immobile HFSE ratios such as $\mathrm{Zr} / \mathrm{Nb}$, from lavas between $19^{\circ}-30^{\circ} \mathrm{S}$ display similar ratios. Furthermore, backarc spreading rate changes south of $30^{\circ} \mathrm{S}$ are minor yet the mantle sources display greater depletion $(\mathrm{Zr} / \mathrm{Nb}>0.01)$. Haase et al. (2002) thus proposed that slab input may be episodic whereby in the northern Kermadec/Tonga Arc, where subduction rates are faster, there are more frequent mantle melting events and consequently over time the mantle becomes progressively more depleted. However, there is no direct evidence to support this possibility. Alternative explanations may be that a shallower dip north of $30^{\circ} \mathrm{S}$ may inhibit sub-arc mantle replenishment (Gamble et al., 1993a; Haase et al., 2002) or the subduction of the Hikurangi Plateau south of $\sim 32^{\circ} S$ which introduces a compositionally distinct component into the subduction system (Timm et al., 2016).

In addition to lateral variations in relative depletion of the mantle source prior to slab enrichment, the pre-subduction modified mantle underlying the Kermadec Arc front is generally more depleted than that beneath the Havre Trough back-arc (e.g., Wysoczanski et al., 2012). This perpendicular source variation is attributed primarily to mantle wedge corner flow induced by the downward motion of a cold subducting slab (figure 1.1). As the mantle flows from beneath the back-arc to the arc front it becomes increasingly depleted due to back-arc magmatism. Slab roll-back, occurring along the Kermadec subduction boundary, accentuates this movement of fertile mantle (McCulloch and Gamble, 1991; Gamble et al., 1993a; Woodhead et al., 1993; Ewart et 
al., 1998; Haase et al., 2002). Source compositions may be further complicated by subduction boundary parallel flow as indicated by shear-wave splitting analyses along subduction zones (Smith et al., 2001; Long and Silver, 2008; Jadamec and Billen, 2010). However, such mantle flow has not been investigated along the Kermadec Arc and shear wave studies suggest this may be a phenomenon primarily present near slab edges (e.g., Lau Backarc; Smith et al., 2001).

The $\mathrm{Sr}-\mathrm{Nd}-\mathrm{Pb}$ isotopic composition of the subducting oceanic crust generally resembles that of variably altered MORB (e.g., Gamble, Woodhead, Wright, \& Smith, 1996; Turner et al., 1997). The isotopic composition of the subducted sediments deposited on the oceanic crust is however heterogeneous (pelagic in the north, increasingly terrigenous in the south) and sediment thickness increases from north to south. Wysoczanski et al. (2006) and Haase et al. (2002) argued that the highest sediment addition in the southern Kermadec arc lavas can be explained by the introduction of relatively small amounts of sediment melt to the mantle wedge source. This is consistent with the aforementioned greater sediment cover of the subducting slab towards the south, noted by lavas with more radiogenic ${ }^{207} \mathrm{~Pb} /{ }^{204} \mathrm{~Pb}$ and ${ }^{208} \mathrm{~Pb} /{ }^{204} \mathrm{~Pb}$ values (Haase et al., 2002). Sediment melting is expected at temperatures greater than $650^{\circ} \mathrm{C}$ (Nichols et al., 1994), after major slab dehydration at $400-600^{\circ} \mathrm{C}$ (Davies and Stevenson, 1992; Peacock, 1996). This melting must take place prior to 100-120 km depth to impact arc magmas. For these parameters to occur, subduction rate needs to be relatively slow, allowing for slab heating. On this basis, Haase et al. (2002) concluded that the SKA, with its slower rate of subduction $\left(\sim 5 \mathrm{~cm} \mathrm{a}^{-1}\right)$ and greater sediment thickness compared to the NKA, allows a greater sediment melt component to be incorporated into arc magmas.

\subsection{Chalcophile and Siderophile elements in the KAHT}

There has been little detailed investigation of the behaviour of chalcophile and siderophile elements in KAHT lavas, however analysis of trace element data for lavas from 15 volcanic centres along KAHT showed that arc front and back-arc lavas are enriched in most chalcophile and siderophile elements in comparison to MORB, with 
the exception of $\mathrm{Ag}$ and $\mathrm{Sn}$ which are depleted compared to MORB (figure 2.3; Timm et al., 2012).

Most Kermadec Arc basalts display high $\mathrm{Cu}, \mathrm{V}, \mathrm{Zn}, \mathrm{Mo} / \mathrm{Yb}$ relative to MORB (figure 2.4), corresponding to higher ratios of fluid-mobile to fluid-immobile elements (e.g., $\mathrm{Ba} / \mathrm{La}, \mathrm{Pb} / \mathrm{Yb}, \mathrm{Sr} / \mathrm{Nd}$ ). This is consistent with a fluid phase from the subducting slab, transporting fluid mobile ( \pm chalcophile) elements into the mantle beneath the KAHT. Alternatively, enrichment may be at least partially attributed to a greater liberation of chalcophile metals from mantle wedge sulfides due to oxidation associated with inflowing slab-derived fluids (Timm et al., 2012).

Havre Through back-arc lavas typically have lower $\mathrm{Cu}, \mathrm{Zn}, \mathrm{Mo}, \mathrm{Sb}, \mathrm{Pb} / \mathrm{MREE}$, HREE values than arc front lavas (figure 2.4), consistent with an expected decrease in fluid input from slab to mantle with increasing distance from the trench.

Base metal elements in SKAHT lavas show variable behaviour during crystal fractionation. Copper, $\mathrm{V}$, and $\mathrm{Zn}$ are incompatible with fractionating phases peaking in concentration in magmas around $50-53 \mathrm{wt} . \% \mathrm{SiO}_{2}$, after which they become compatible in fractionating phases and their contents decrease significantly with increasing $\mathrm{SiO}_{2}$. Other metal elements such as $\mathrm{Mo}, \mathrm{Bi}, \mathrm{Pb}$, and $\mathrm{As}$, are variably incompatible and increase in content with increasing $\mathrm{SiO}_{2}$ (Timm et al., 2012).

Tin, Ag, and HFSE concentrations within mafic southern Tonga-Kermadec Arc lavas are similar to and overlap with MORB. This suggests these elements are impacted less by the addition of hydrous fluids, either as a transport medium from the slab or as a liberation mechanism from mantle sulfides. Conversely, dacitic lavas of the Brothers volcanic centre show higher concentrations of fluid immobile elements (e.g., Th, LREE, MREE, Sn, Ag, Mo, Nb, Zr, Y, Hf) than other dacites from the Kermadec Arc. Timm et al. (2012) concluded that these additions of fluid-immobile trace elements, including the chalcophiles $\mathrm{Sn}$ and $\mathrm{Ag}$, are best explained by the partial melting of and mixing within the mantle of sediment or supercritical fluids, in addition to hydrous fluid release. 
Figure 2.3: Select elements vs. $\mathrm{SiO}_{2}$ (wt.\%). (a) Cu, (b) V, (c) Zn, (d) Ag, (e) Sn, (f) Sb, (g) Mo, (h) Bi, (i) As, and (j) Pb ppm. Grey field presents MORB, white field represents back-arc basalts (BAB; Haase et al., 2002; Todd et al., 2011). Dotted line marks onset of magnetite crystallization. Sourced from Timm et al. (2012). 
Figure 2.4: Along arc variations of (a) $\mathrm{Cu} / \mathrm{Yb}$, (b) $\mathrm{V} / \mathrm{Yb}$, (c) $\mathrm{Zn} / \mathrm{Yb}$, (d) $\mathrm{Mo} / \mathrm{Yb}$, (e) $\mathrm{Ag} / \mathrm{Yb}$, and (f) Bi/Nd*100. Grey dotted line marks average MORB composition (Hertogen et al., 1980; Sun and McDonough, 1989; Yi et al., 2000; Jenner et al., 2010), grey solid line marks average composition of southern Lau Basin/Havre Trough back-arc BAB (Haase et al., 2002). $\mathrm{Yb}$ and $\mathrm{Nd}$ values in $\mathrm{Ag} / \mathrm{Yb}, \mathrm{Cu} / \mathrm{Yb}$, and $\mathrm{Bi} / \mathrm{Nd}$ ratios represent average Pacific $\mathrm{MORB}$ from the PetDB and GeoRoc databases (where $\mathrm{MgO}>5$ wt.\%). $\mathrm{Cu} / \mathrm{Yb}, \mathrm{Zn} / \mathrm{Yb}$, and $\mathrm{V} / \mathrm{Yb}$ are not shown for $\mathrm{SiO}_{2}>55$ wt.\% to avoid the effect of magnetite crystallization. Sourced from Timm et al. (2012). 


\subsection{Sample locations}

\subsubsection{Rumble II East and West}

The two Kermadec arc front volcanoes Rumble II East and West are closely associated and form a short, arc perpendicular transect of volcanoes. Rumble II East is aligned with the volcanic front and Rumble II West is located $\sim 13 \mathrm{~km}$ behind the volcanic front. Rumble II West samples used in this study were recovered from the south western caldera (11C) and the ridge to the south eastern caldera (16B and 30C; table 1.1) with the RV Tangaroa (NZAMS, TAN1104 expedition). Rumble II West is situated at $\sim 35.36^{\circ} \mathrm{S} / 178.5^{\circ} \mathrm{E}$, approximately $230 \mathrm{~km}$ to the west of the Kermadec trench (figure 2.1; Timm et al., 2016). Rumble II West forms a volcanic complex at $\sim 1800$ to $1194 \mathrm{mbsl}$ (metres below sealevel), with a basal area of $\sim 19 \mathrm{~km} \times 16 \mathrm{~km}$ (figure 2.5) and a total constructional volume of $108 \mathrm{~km}^{3}$ (Timm et al., 2016). Based on volatile contents of olivine hosted melt inclusions, Wysoczanski et al. (2012) calculated magma chamber depths for Rumble II West at 3300 mbsf (metres below sea floor). This calculation took into account the overlying water column and using an average arc crustal density of $2.5 \mathrm{~g} / \mathrm{cm}^{3}$. These depths are comparable to estimates based on modelling using ship-derived gravity data (figure 2.6; Timm et al., 2016). The Bouguer anomaly modelling predicted a larger magma reservoir beneath Rumble II West between 4000 and $6000 \mathrm{mbsl}$ (figure 2.6). The modelling further suggested that crustal thickness beneath Rumble II West is $\sim 6.5 \mathrm{~km}$ (Timm et al., 2016).

Lava sampled from Rumble II West rocks are generally vesicular ( 20 - 45\% vesicles) and have dominant plagioclase glomerocrysts with lesser amounts of clinopyroxene and olivine, in a groundmass comprised of plagioclase, minor clinopyroxene and glass (Leybourne et al., 2012; Timm et al., 2016). These assemblages are similar to most Kermadec Arc lavas, which are typically porphyritic basalts and basaltic andesites (15-60\% phenocrysts) with plagioclase commonly being the dominant phase (Gamble et al., 1990). 
Figure 2.5: Bathymetric map of Rumble II East and Rumble II West. Sourced from Timm et al. (2016).

Figure 2.6: Gravity model for Rumble II East and West along profile $A^{\prime}$ to $A^{\prime \prime}$ in figure 2.5. Top is measured and modelled shipboard gravity anomaly. Bottom is the cross section constructed by Timm et al. (20016) using the gravity data. The low-density volcanic edifices of Rumble II East and West (yellow) and the block of 'high-density' crust (dark brown) between the two edifices was required to model gravity presence of the magma chambers (red). Green is pyroxenitc Moho transition or the crust-mantle boundary as inferred from seismic data at the Izu-BoninMariana arc (Takahashi et al., 2009). Sourced from Timm et al. (2016).

Compositionally, Rumble II West lavas range from basalt through basaltic andesite to andesite. These lavas display enrichment in LREE and other fluid-mobile elements such as $\mathrm{Sr}, \mathrm{U}, \mathrm{Ba}, \mathrm{Rb}$, and $\mathrm{Cs}$, with depletion of $\mathrm{Nb}, \mathrm{Zr}$, and $\mathrm{Hf}$ relative to 
MORB, similar to other Rumble seamounts (Rumble I-V) and consistent with typical arc lavas (Gamble et al., 1993; Timm et al., 2016). Rumble II West glasses calculated measured $f_{\mathrm{O}_{2}}$ ranging from approximately $0.67-1.5 \mathrm{FMQ}$, estimated from sulfur speciation (Wysoczanski et al., 2012).

Rumble II West is hydrothermally active and hosts VMS deposits. Hydrothermal plume activity is evident by a small $\delta^{3} \mathrm{He}$ anomaly, suggesting hydrothermal quiescence relative to some other SKAHT volcanoes, however activity appears to be increasing on the basis of observations over the last couple of decades (de Ronde et al., 2012; Leybourne et al., 2012). Hydrothermal chimneys were first observed in 1999, with several more found within and near the two main calderas (Leybourne et al., 2012). A sulfide-bearing sample composed of chalcopyrite $\left(\mathrm{CuFeS}_{2}\right)$ and pyrite $\left(\mathrm{FeS}_{2}\right)$ within a barite $\left(\mathrm{BaSO}_{4}\right)$ matrix (Wright et al., 1998; de Ronde et al., 2003; Leybourne et al., 2012) was collected in 1996 (X656). Several more sulfide samples were collected in 2011 with one containing massive barite \pm pyrite and sphalerite $(\mathrm{Zn}, \mathrm{FeS})$ with trace amounts (0.01\%) galena (PbS; Leybourne et al., 2012).

\subsubsection{Rumble III}

Rumble III is a submarine volcano located $\sim 40 \mathrm{~km}$ south of Rumble II East and West, along the active arc front at $35.716^{\circ} \mathrm{S}, 178.483^{\circ} \mathrm{E}$ (figure $1.4 ; 2.1$ ). The stratovolcano is one of the largest active volcanoes along the Kermadec Arc, featuring a basal diameter of approximately $25 \mathrm{~km}$ at $\sim 2500 \mathrm{~m}$ below sea level (Tontini et al., 2013). It features three main eruption centres, a southern and central cone and a northwest caldera, together making Rumble III slightly elongate (figure 2.7). The southern cone marks the shallowest point, rising to $\sim 200 \mathrm{~m}$ water depth (Wright, 1994; Wright et al., 2002; Tontini et al., 2013).

Compositionally, Rumble III lavas range from generally basaltic andesite to andesite (Gamble et al., 1996; Wysoczanski et al., 2012). These lavas, like those of Rumble II West, display enrichment of fluid-mobile elements, with depletions of fluidimmobile elements (e.g., Nb, Zr, Hf) relative to MORB (Wysoczanski et al., 2012). The calculated $f_{\mathrm{O}_{2}}$ of Rumble III glasses are similar to that of Rumble II West, varying from 〜 $0.63-1.5$ FMQ. 
Like Rumble II West, Rumble III is hydrothermally active as noted by plumes of volcanic volatiles, dissolved Fe and $\mathrm{Mn}$, and a notably high $\delta^{3} \mathrm{He}$ anomaly (de Ronde et al., 2001). Three major centres of collapse have been identified on Rumble III which may be tied to hydrothermal alteration and associated edifice weakening (figure 2.6; Tontini et al., 2013).

Figure 2.7: 3D morphology of Rumble III from a NW perspective view. Identifying main volcanic features (Southern Cone, Central Cone, and NW caldera) as well past slope failures. Vertical exaggeration is 2.5 times. Sourced from Tontini et al., (2013).

\subsubsection{Basins D and I}

Compared to the arc front volcanoes, basins $D$ and I have been minimally studied, with three and five whole rock samples, respectively, analysed as part of a MSc thesis (Pullan, 2018) which included detailed mapping of the back-arc basins.

Basin D is approximately $20 \mathrm{~km}$ east from Rumble II West and is $\sim 59 \mathrm{~km}$ long, $20 \mathrm{~km}$ wide at a depth of $2500-3000 \mathrm{mbsl}$ (figure 2.8A). Samples were collected from the northern part of the basin $\left(35.39^{\circ} \mathrm{S}, 178.23^{\circ} \mathrm{E}\right.$; sample $51-6$; figure $\left.2.8 \mathrm{~A}\right)$ which features extensive ridges ( $60-80 \mathrm{~m}$ high), oriented $045^{\circ}$. Basin $D$ features a few small cones (figure 2.8A) that are $\sim 2 \mathrm{~km}$ wide, $3-5 \mathrm{~km}$ long and range in elevation by $\sim$ 200 m (Pullan, 2018). 
Basin I is situated $\sim 15 \mathrm{~km}$ from Colville Ridge and is $\sim 59 \mathrm{~km}$ wide and $\sim 37 \mathrm{~km}$ long at a depth of approximately $3000 \mathrm{mbsl}$ (figure 2.8B). Basin I features four main ridges. Samples for this study (sample 040) were collected from the westernmost ridge (Ridge $A$; figure $2.8 \mathrm{~B}$ ) at $35.316^{\circ} \mathrm{S}, 177.75^{\circ} \mathrm{E}$. Ridge $\mathrm{A}$ is $2 \mathrm{~km}$ wide and $18 \mathrm{~km}$ long. Similar to Basin D, several small cones are present in Basin I (figure 2.8B) that have basal diameters ranging from $2-2.5 \mathrm{~km}^{2}$.

SKAHT back-arc lavas (including Basins D and I) are generally basaltic with a porphyritic texture whereby the dominant phenocryst phases are plagioclase + olivine + pyroxene ( $\sim 5-25$ vol.\% phenocrysts). The vesicularity of the samples vary widely between 20-60 vol.\% (Pullan, 2018). In contrast to arc front volcanoes, back-arc basins display no evidence of hydrothermal activity. Trace element data is consistent with variable subduction input into the mantle source (Pullan, 2018). 
Chapter 3: Analytical Techniques and Methods 


\subsection{Sample preparation}

\subsubsection{Rock crushing and glass/olivine separation}

All rock samples were collected from the seafloor via dredges during three expeditions of the RV Tangaroa between 2011 and 2015 (TAN1104, TAN1213, \& TAN1513). Their original emplacement along the seafloor means that alteration due to reactions with ocean water may affect bulk rock composition. However, as the focus of this study is on glass shards and olivine hosted melt inclusions, selection of fresh glass material should avoid seawater alteration effects.

The glassy rims of sample pillow lavas were targeted as these contain both groundmass glass and olivine grains featuring uncrystallised melt inclusions. The rims were initially removed from whole rock samples using a cold chisel and hammer. This material was identified as a lustrous-black rim on the outermost portion of the rock samples, indicative of the rapidly quenched lava upon interaction with ocean waters. Between chiselling of individual samples, the work bench was wiped down and cleaned with ethanol to avoid any cross-contamination between samples.

Glass rim material was crushed to a grain size of approximately $0.2-1 \mathrm{~mm}$ (excluding rock dust) using a mortar and pestle. The purpose of this step was to separate olivine crystals from host glass material. After each sample was crushed the mortar and pestle were cleaned using first a cleaning brush and then ethanol. Risk of cross contamination was low as coarse material was easy to clean off and no very fine material was selected in further steps.

A portion of each sample was placed into a glass dish to be examined under a binocular microscope. Deionised water was added to the dish to separate fine particles from the glass and olivine grains of interest. Between samples, glass dishes were brushed and wiped down using ethanol.

Olivine grains were collected first. These were easily identifiable by their generally equant shape and colourless transparency, due to low iron content. Both features made them distinct from all other grains in the samples. Most olivine grains found containing evident melt inclusions, identifiable as dark globules within the grain, were preferentially selected. Care was taken to ensure dark spots were not glass still 
attached to the edges of the olivine grains. However, grains without obvious melt inclusions were still collected as smaller inclusions may become apparent later under more meticulous inspection. Grains were separated and manipulated using fine tweezers.

Samples were then examined for the collection of pristine glass shards. These were identified by their transparent brown colouration. During collection, bias was given towards larger glass shards and uniform colouration.

\subsubsection{Preparation for analysis}

Analysis of water and carbon species using Fourier Transform Infrared (FTIR) spectrometry requires olivine hosted melt inclusions and glass samples to be doubly polished to minimize beam disturbance. Despite this not being required for compositional analysis via EPMA and LA-ICPMS, all samples were prepared in this way. For olivine hosted melt inclusions, one polished side must expose the melt inclusion, whereas it is sufficient for the other to only intersect the olivine grain. For all analyses, only pristine glassy melt inclusions, with no evidence of crystallization, were utilised in order to avoid re-homogenization processes and the accompanied uncertainties such as loss of trace and volatile elements and reduction in the oxidation state of the melt (Frezzotti, 2001; Rowe et al., 2007). Sample preparation followed the procedures of von Aulock et al. (2014), which involved mounting the grains in Crystal bond and carefully polishing by hand using progressive finer grit to expose melt inclusions. The samples were then removed from the Crystal bond, flipped, re-mounted and polished again to get a flat surface parallel to the face intersecting the melt inclusion.

\subsection{FTIR analysis}

Water and carbon species contents of melt inclusions were measured using FTIR. Due to logistic and time restrictions, a portion of the total olivine hosted melt inclusions were selected for FTIR analysis. Grains selected were those where only the exposed melt inclusion(s) and host underlying olivine crystal would be present along the path of analysis. Prior to analysis, selected sample grains were separated from the 
mounts and rested overnight in acetone to dissolve any residual Crystal bond. Select samples were analysed using a Nicolet 6700 FTIR at the Department of Soil and Earth Sciences, Massey University. The effect of the underlying host olivine was removed using spectral bands diagnostic of olivine (following Nichols \& Wysoczanski, 2007), thus avoiding the difficult task of doubly exposing melt inclusions.

Ideally, water intensities are measured at both $3550 \mathrm{~cm}^{-1}$ stretching vibration (total water) and the $1630 \mathrm{~cm}^{-1}$ vibration (molecular water) in order to determine speciation. However, the mid-IR region, through olivine grains contains a Si-O overtone and combination bands between $\sim 2000$ and $1600 \mathrm{~cm}^{-1}$. Critically, in a singly exposed inclusion within an olivine host, these overlap the molecular water absorbance peak at $1630 \mathrm{~cm}^{-1}$. However, $\mathrm{H}_{2} \mathrm{O}$ wt.\% can still be determined using the $\mathrm{H}_{2} \mathrm{O}$ at $3550 \mathrm{~cm}^{-1}$ implementing the Beer-Lambert law:

$$
c_{i}=\frac{M_{i} \cdot A}{\rho \cdot t \cdot \varepsilon}
$$

where $c_{i}$ is the concentration of species $i$ (in wt.\%), $M_{i}$ is the molecular weight of the species $i\left(\mathrm{gmol}^{-1}\right), A$ is the absorbance (height) of the relevant vibration band (e.g., height of $3550-\mathrm{cm}^{-1}$ peak for $\left.\mathrm{H}_{2} \mathrm{O}\right), p$ is the sample density $(\mathrm{g} / \mathrm{l}), t$ is the thickness of the sample $(\mathrm{cm})$ and $\varepsilon$ is the molar absorptivity $(1 / \mathrm{mol} \cdot \mathrm{cm})$. Molar absorptivity values of $63 \pm 5$ and $25 \pm 3$ are used for total $\mathrm{H}_{2} \mathrm{O}$ and molecular $\mathrm{H}_{2} \mathrm{O}$, respectively (Dixon et al., 1988; Nichols and Wysoczanski, 2007). Glass density was calculated from its oxide composition, measured by EPMA (Lange, 1997) with $\mathrm{H}_{2} \mathrm{O}$ being calculated iteratively. Sample thickness is derived from the wavelength of interference fringe patterns from reflectance spectra. These wavelengths are directly proportional to the thickness and refractive index of the sample (Nishikida et al., 1995; Wysoczanski and Tani, 2006):

$$
t=\frac{m}{2 n\left(v_{1}-v_{2}\right)}
$$

where $t$ is the thickness of the area analysed $(\mathrm{cm}), m$ is the number of waves over a selected interval of wavenumbers between $v_{1}$ and $v_{2}, n$ is the refractive index of the material through which the spectra have been measured. A refractive index of 1.546 was used for inclusions as this is the refractive index of basaltic glass (Kumagai and Kaneoka, 2003). 
Similarly, $\mathrm{CO}_{2}$ can be calculated using couplet peaks at $1515 \mathrm{~cm}^{-1}$ and $1435 \mathrm{~cm}^{-1}$ generated by the antisymmetric stretching of distorted $\mathrm{CO}_{3}{ }^{2-}$ groups, using a molar absorptivity of $375 \pm 20 \mathrm{l} / \mathrm{mol} \cdot \mathrm{cm}$ (Fine and Stolper, 1985). However, these peaks may not be present if $\mathrm{CO}_{2}$ has degassed from the magmas.

All measured $\mathrm{H}_{2} \mathrm{O}$ and $\mathrm{CO}_{2}$ contents of melt inclusions analysed in this study are presented in Appendix B.

\subsection{EPMA analysis}

All samples were analysed using a JEOL JXA-8230 EPMA at Victoria University of Wellington. Glasses were analysed for sulfur, $\mathrm{Cl}$ and major elements, and olivine crystals were also analysed for major and minor ( $\mathrm{Ni}$ and $\mathrm{Cr}$ ) elements.

Grains were set in epoxy mounts suitable for both EPMA and LA-ICPMS analysis. Frist they were placed onto double sided adhesive tape in an organised grid, and checked to ensure the exposed melt inclusions were facing down. A mould was then placed around the grains and partly filled with an epoxy mixture and weighed down to keep the epoxy within the mould. Once set, the epoxy mounts were separated from both the mould and double-sided tape. The bottom side was wiped down using ethanol and given a final polish using $3 \mu \mathrm{m}$ and then $1 \mu \mathrm{m}$ diamond solution to remove any residual adhesive. Care was taken to ensure the inclusions were not polished into further.

Ground mass glass grains were similarly prepared without prior polishing. After these were mounted within the epoxy mount, the bottom was polished firstly with 2500 grit sanding paper to expose a fresh surface and then $3 \mu \mathrm{m}$ and $1 \mu \mathrm{m}$ diamond solution to remove significant surface scratches. All grain mounts were then carbon coated, with four coats of $4 \mu \mathrm{m}$ applied to each, for a total $16 \mu \mathrm{m}$ thickness.

Beam conditions used were a 15-kV accelerating voltage, 8-nA beam current, and a defocused spot (10- $\mathrm{mm}$ spot size) for glass compositions, and 15-kV, 20-nA, and a focused spot for olivine analyses. Primary standards for olivine compositions were Springwater olivine and Jk3-olivine (Fe, Mg), wollastonite (Ca), and synthetic oxides for $\mathrm{Al}_{2} \mathrm{O}_{3}, \mathrm{NiO}, \mathrm{MnO}$, and $\mathrm{Cr}_{2} \mathrm{O}_{3}$. 
Analytical precision and reproducibility of olivine analyses was monitored by analysing Springwater olivine and Jk3-olivine. Olivine analyses included core, rim, and near-inclusion points. The latter required for reintegration of olivine growth from the melt inclusion. Standard analyses were regularly taken throughout an analytical run.

A slight doming of some olivine grain edges was apparent as a result of the individual grain polishing techniques. Therefore, some analyses resulted in minor, although notable, discrepancies relating to total oxide values. However, back-scatter imaging suggest the majority of olivine grains were unzoned and analyses could be obtained from regions within the grain where the doming was less or not apparent.

Analytical precision and reproducibility of melt inclusions and groundmass glass compositions were monitored by analysing four volcanic glass standards of varying compositions; VG-568, VG-A99, VG2, \& Indian Ocean basaltic glass (USNM 113716; Tables 3.0-1, 3.0-2, 3.0-3, 3.0-4). Primary standards included VG-568 (Na, K), VG-A99 (Fe, Si, Ca, Mg, Al), scapolite (Cl), Elba Pyrite (S), Durango apatite (P), and synthetic oxides; $\mathrm{TiO}_{2}, \mathrm{MnO}, \& \mathrm{Cr}_{2} \mathrm{O}_{3}$. Original major element compositions of olivine grains, associated melt inclusions and groundmass glass are presented in Appendix $A, B$, and $D$ respectively.

Table 3.0-1: List of measured and preferred values of major and minor element abundances of glass standard VG568 Rhyolite. Reference values were obtained from Jarosewich et al., (1980). All values are given in wt.\%.

\begin{tabular}{|c|c|c|c|c|c|c|c|}
\hline \multicolumn{7}{|c|}{$\begin{array}{c}\text { VG-568 Rhyolite } \\
\mathbf{n}=\mathbf{3 4}\end{array}$} \\
\hline & Mean & Min & Max & 2 SD & 2 SD \% & Reference & \% offset \\
\hline SiO2 & 77.73 & 76.71 & 78.84 & 1.14 & 1.5 & 76.96 & 1.0 \\
\hline TiO2 & 0.07 & 0.05 & 0.09 & 0.02 & 32.74 & 0.08 & -22 \\
\hline Al203 & 12.38 & 12.27 & 12.62 & 0.15 & 1.3 & 12.17 & 1.7 \\
\hline FeO & 1.08 & 0.90 & 1.22 & 0.18 & 16 & 1.08 & -0.35 \\
\hline MnO & 0.015 & 0.0 & 0.04 & 0.024 & 158 & 0.02 & -29 \\
\hline MgO & 0.03 & 0.01 & 0.05 & 0.02 & 71 & 0.03 & -2.5 \\
\hline CaO & 0.45 & 0.43 & 0.48 & 0.02 & 5.2 & 0.45 & 0.33 \\
\hline Na20 & 3.65 & 2.86 & 3.99 & 0.46 & 13 & 3.52 & 3.6 \\
\hline K20 & 4.97 & 4.88 & 5.14 & 0.12 & 2.4 & 4.93 & 0.82 \\
\hline Cr203 & 0.01 & 0.0 & 0.05 & 0.03 & 248 & & \\
\hline P2O5 & 0.0 & 0.0 & 0.0 & 0.0 & 0.0 & & \\
\hline S & 0.0 & 0.0 & 0.01 & 0.01 & 176 & & \\
\hline Cl & 0.11 & 0.08 & 0.16 & 0.03 & 27 & 0.10 & 3.6 \\
\hline & & & & & & & \\
\hline Total & 100.49 & 99.19 & 101.96 & & & 99.24 & \\
\hline
\end{tabular}


Table 3.0-2: List of measured and preferred values of major and minor element abundances of glass standard VGA99. Reference values were obtained from Jarosewich et al., (1980). All values are given in wt.\%.

\begin{tabular}{|c|c|c|c|c|c|c|c|}
\hline \multicolumn{7}{|c|}{$\begin{array}{c}\text { VG-A99 Rhyolite } \\
\mathbf{n}=\mathbf{3 4}\end{array}$} \\
\hline & Mean & Min & Max & 2 SD & 2 SD \% & Reference & \% offset \\
\hline SiO2 & 51.00 & 50.44 & 51.69 & 0.74 & 1.4 & 51.01 & -0.01 \\
\hline TiO2 & 4.02 & 3.88 & 4.11 & 0.11 & 2.7 & 4.12 & -2.6 \\
\hline Al2O3 & 12.51 & 12.21 & 12.75 & 0.25 & 2.0 & 12.47 & 0.30 \\
\hline FeO & 13.57 & 12.74 & 14.12 & 0.63 & 4.6 & 13.35 & 1.6 \\
\hline MnO & 0.17 & 0.10 & 0.21 & 0.05 & 29 & 0.20 & -21 \\
\hline MgO & 5.02 & 4.85 & 5.27 & 0.22 & 4.4 & 5.05 & -0.55 \\
\hline CaO & 9.26 & 8.97 & 9.43 & 0.17 & 1.9 & 9.23 & 0.38 \\
\hline Na20 & 2.66 & 2.46 & 2.86 & 0.19 & 7.3 & 2.68 & -0.79 \\
\hline K2O & 0.86 & 0.80 & 0.93 & 0.06 & 6.4 & 0.84 & 2.4 \\
\hline Cr2O3 & 0.01 & 0.0 & 0.07 & 0.04 & 279 & 0.02 & -18 \\
\hline P205 & 0.30 & 0.23 & 0.35 & 0.07 & 23 & 0.44 & -46 \\
\hline S & 0.01 & 0.01 & 0.02 & 0.01 & 64 & & \\
\hline Cl & 0.02 & 0.01 & 0.04 & 0.01 & 56 & 0.10 & -327 \\
\hline & & & & & & & \\
\hline Total & 99.31 & 97.27 & 100.89 & & & 99.24 & \\
\hline
\end{tabular}

Table 3.0-3: List of measured and preferred values of major and minor element abundances of glass standard VG2. Reference values were obtained from Jarosewich et al., (1980). All values are given in wt.\%.

\begin{tabular}{|c|c|c|c|c|c|c|c|}
\hline \multicolumn{7}{|c|}{$\mathbf{n = 2 0}$} \\
\hline & Mean & Min & Max & 2 SD & 2 SD \% & Reference & \% offset \\
\hline SiO2 & 50.76 & 50.31 & 51.20 & 0.44 & 0.86 & 50.81 & -0.10 \\
\hline TiO2 & 1.82 & 1.71 & 1.89 & 0.10 & 5.39 & 1.85 & -1.91 \\
\hline Al203 & 13.99 & 13.79 & 14.16 & 0.21 & 1.47 & 14.06 & -0.53 \\
\hline FeO & 12.04 & 11.26 & 12.59 & 0.65 & 5.40 & 12.06 & -0.17 \\
\hline MnO & 0.20 & 0.17 & 0.24 & 0.04 & 19.03 & 0.22 & -9.32 \\
\hline MgO & 7.01 & 6.90 & 7.19 & 0.17 & 2.37 & 6.71 & 4.31 \\
\hline CaO & 11.09 & 10.91 & 11.20 & 0.15 & 1.38 & 11.12 & -0.31 \\
\hline Na20 & 2.67 & 2.54 & 2.88 & 0.17 & 6.48 & 2.62 & 1.86 \\
\hline K20 & 0.20 & 0.16 & 0.23 & 0.03 & 15.3 & 0.19 & 4.04 \\
\hline Cr203 & 0.02 & 0.00 & 0.05 & 0.03 & 189 & & \\
\hline P2O5 & 0.06 & 0.02 & 0.11 & 0.05 & 92.9 & 0.20 & -258.74 \\
\hline S & 0.14 & 0.12 & 0.15 & 0.02 & 12.6 & & \\
\hline Cl & 0.03 & 0.02 & 0.05 & 0.01 & 46.07 & & \\
\hline & & & & & & & \\
\hline Total & 100.22 & 99.66 & 101.16 & & & 99.84 & \\
\hline
\end{tabular}


Table 3.0-4: List of measured and preferred values of major and minor element abundances of glass standard USNM 113716. Reference values were obtained from Jarosewich et al., (1980). All values are given in wt.\%.

\begin{tabular}{|c|c|c|c|c|c|c|c|}
\hline \multicolumn{8}{|c|}{$\begin{array}{c}\text { USNM } 113716 \\
n=20\end{array}$} \\
\hline & Mean & Min & Max & $2 S D$ & 2 SD \% & Reference & $\%$ offset \\
\hline SiO2 & 51.65 & 51.10 & 51.94 & 0.23 & 0.44 & 51.52 & 0.25 \\
\hline TiO2 & 1.29 & 1.19 & 1.34 & 0.04 & 3.3 & 1.30 & -0.88 \\
\hline Al2O3 & 15.32 & 15.15 & 15.87 & 0.17 & 1.1 & 15.39 & -0.49 \\
\hline $\mathrm{FeO}$ & 8.90 & 8.14 & 9.54 & 0.32 & 3.5 & 9.24 & -3.8 \\
\hline $\mathrm{MnO}$ & 0.17 & 0.12 & 0.20 & 0.02 & 11 & 0.17 & -2.0 \\
\hline MgO & 8.20 & 7.44 & 8.81 & 0.24 & 3.0 & 8.21 & -0.14 \\
\hline $\mathrm{CaO}$ & 11.39 & 10.81 & 12.01 & 0.24 & 2.1 & 11.31 & 0.70 \\
\hline $\mathrm{Na2O}$ & 2.65 & 2.48 & 2.86 & 0.11 & 4.0 & 2.48 & 6.4 \\
\hline $\mathrm{K} 20$ & 0.07 & 0.05 & 0.10 & 0.01 & 17 & 0.09 & -25 \\
\hline Cr2O3 & 0.04 & 0.02 & 0.09 & 0.02 & 40 & & \\
\hline P2O5 & 0.01 & 0.0 & 0.02 & 0.0 & 56 & 0.12 & -1264 \\
\hline$S$ & 0.11 & 0.10 & 0.12 & 0.01 & 5.2 & & \\
\hline $\mathrm{Cl}$ & 0.0 & 0.0 & 0.01 & 0.0 & 119 & & \\
\hline Total & 99.95 & 98.4 & 100.6 & & & 99.83 & \\
\hline
\end{tabular}

Table 3.0-5: List of measured and preferred values of major and minor element abundances of olivine standard Springwater Olivine. Reference values were obtained from Jarosewich et al., (1980). All values are given in wt.\%.

\begin{tabular}{|c|c|c|c|c|c|c|c|}
\hline \multicolumn{7}{|c|}{$\begin{array}{c}\text { Springwater Olivine } \\
\mathbf{n}=\mathbf{4 6}\end{array}$} \\
\hline & Mean & Min & Max & 2 SD & 2 SD (\%) & Reference & \% Offset \\
\hline SiO2 & 39.11 & 38.61 & 40.40 & 0.56 & 1.44 & 39.0 & 0.41 \\
\hline TiO2 & 0.0 & 0.0 & 0.0 & 0.0 & 616 & & \\
\hline Al2O3 & 0.0 & 0.0 & 0.02 & 0.01 & 287 & & \\
\hline FeO & 16.83 & 15.26 & 17.42 & 0.72 & 4.27 & 16.6 & 1.2 \\
\hline MnO & 0.32 & 0.28 & 0.36 & 0.04 & 11 & 0.30 & 5.9 \\
\hline MgO & 43.80 & 43.13 & 44.15 & 0.44 & 1.00 & 43.6 & 0.50 \\
\hline CaO & 0.01 & 0.0 & 0.03 & 0.01 & 87 & & \\
\hline Cr2O3 & 0.02 & 0.0 & 0.06 & 0.03 & 123 & 0.02 & 17.8 \\
\hline NiO & 0.01 & 0.0 & 0.05 & 0.02 & 404 & & \\
\hline & & & & & & & \\
\hline Total & 100.10 & 97.52 & 101.09 & & & 99.47 & 0.63 \\
\hline
\end{tabular}


Table 3.0-6: List of measured and preferred values of major and minor element abundances of olivine standard JK3 Olivine. Reference values were obtained from (Chazot et al., 1996). All values are given in wt.\%.

\begin{tabular}{|c|c|c|c|c|c|c|c|}
\hline \multicolumn{7}{|c|}{$\begin{array}{c}\text { JK3 (Olivine) } \\
\mathbf{n}=\mathbf{3 0}\end{array}$} \\
\hline & Mean & Min & Max & 2 SD & 2 SD (\%) & Reference & $\begin{array}{c}\text { \% } \\
\text { Offset }\end{array}$ \\
\hline SiO2 & 40.34 & 39.90 & 41.57 & 0.61 & 1.52 & 41 & -2.5 \\
\hline TiO2 & 0.0 & 0.0 & 0.0 & 0.0 & 764 & 0.01 & \\
\hline Al2O3 & 0.0 & 0.0 & 0.01 & 0.01 & 182 & 0.0 & \\
\hline FeO & 9.62 & 9.06 & 9.91 & 0.39 & 4.05 & 9.6 & 0.03 \\
\hline MnO & 0.14 & 0.11 & 0.17 & 0.03 & 18.1 & 0.18 & -25 \\
\hline MgO & 49.41 & 48.45 & 49.89 & 0.57 & 1.15 & 49 & 1.75 \\
\hline CaO & 0.04 & 0.03 & 0.05 & 0.01 & 22.7 & 0.03 & 24 \\
\hline Cr2O3 & 0.01 & 0.0 & 0.04 & 0.02 & 182 & 0.04 & -315 \\
\hline NiO & 0.36 & 0.31 & 0.40 & 0.05 & 13.1 & 0.04 & 89 \\
\hline & & & & & & & \\
\hline Total & 99.93 & 98.92 & 100.66 & & & 100.31 & -0.38 \\
\hline
\end{tabular}

\subsection{LA-ICPMS analysis}

Prior to LA-ICPMS analysis, all sample mounts were polished using $1 \mu \mathrm{m}$ diamond polish to remove the carbon coat. Sample mounts were loaded together with standard glass mounts; BHVO-2-G, BCR-2G, and NIST612, which were used for calibration and monitoring drift throughout the analytical run. Trace element concentrations of glass and melt inclusions were measured using a Resonetics S155-SE (193 nm) Excimer laser coupled to an Agilent 7900 ICPMS at Victoria University of Wellington. All data were acquired as static spot analysis on the same spot locations as were analysed using the EPMA. Three analytical runs were undertaken, targeting groundmass glasses (50 $\mu \mathrm{m}$ spot size, 50 second analysis), melt inclusions suitable for $40 \mu \mathrm{m}$ spot size (40 second analysis), and $30 \mu \mathrm{m}$ spot size (30 second analysis). Samples were ablated with He gas $(400 \mathrm{~mL} / \mathrm{min})$ in the sample chamber, and with $\mathrm{Ar}$ (910 $\mathrm{mL} / \mathrm{min})$ and $\mathrm{N}_{2}(2 \mathrm{~mL} / \mathrm{min})$ added as carrier gasses to the ICPMS. The laser parameters were set to an energy of $12 \mathrm{~mJ}$, attenuation of $12.5 \%$ transmission, and a 
repetition rate of $10 \mathrm{~Hz}$. Bracketing BHVO-2G calibration analyses were undertaken every four sample analyses, and each spot analysis was followed by 60 seconds washout, allowing for a 30 second baseline measurement to be taken.

Abundances were derived from counts per second data, using IOLITE software with BHVO-2G as the primary standard and $\mathrm{Si}$ as reference mass to calibrate trace element data with $\mathrm{SiO}_{2}$ measured by EPMA. In total 52 trace elements were measured (table 3.0-7). BHVO-2-G was used as the reference material as it is well characterised for the elements of interest and closely matrix matches the basalt-basaltic andesite glasses analysed. BCR-2G was measured as a secondary standard to check accuracy (table 3.0-8) with most elements agreeing within $5 \%$ of reference values, $\mathrm{Sc}, \mathrm{Zn}, \mathrm{Ni}, \mathrm{W}$, Th, and low abundance M-HREE within 10\%, and Cu within 17\%. NIST612, an artificial silica glass standard, was also analysed multiple times throughout the analytical runs (table 3.0-9). Note that there is a systemic offset of approximately $10-14 \%$ from reference values for concentrations for the heavier masses in particular, showing the importance of matrix-matching standards to samples, even amongst glasses.

Trace element measurements of all melt inclusions and groundmass glasses investigated in this study are presented in Appendix $C$ and $D$ respectively. 
Table 3.0-7: List of measured and preferred values for trace element abundances of glass standard BHVO-2-G. Reference values were obtained from Jochum \& Enzweiler (2014). All values are given in ppm.

\begin{tabular}{|c|c|c|c|c|c|}
\hline \multicolumn{6}{|c|}{$\begin{array}{c}\text { BHVO-2-G } \\
n=27\end{array}$} \\
\hline & Mean & Min & Max & 2 SD & 2 SD (\%) \\
\hline Li & 4.4 & 4.23 & 4.59 & 0.14 & 3.14 \\
\hline Sc & 33.0 & 32.8 & 33.2 & 0.28 & 0.85 \\
\hline $\mathrm{Ti}$ & 16727 & 16570 & 16860 & 145 & 0.87 \\
\hline V & 308 & 304 & 310 & 2.69 & 0.87 \\
\hline $\mathrm{Cr}$ & 293 & 290 & 297 & 3.81 & 1.30 \\
\hline $\mathrm{Mn}$ & 1317 & 1306 & 1334 & 14.2 & 1.08 \\
\hline Co & 44.0 & 43.5 & 44.4 & 0.45 & 1.03 \\
\hline $\mathrm{Ni}$ & 116 & 114 & 118 & 1.33 & 1.15 \\
\hline $\mathrm{Cu}$ & 127 & 126 & 128 & 1.19 & 0.94 \\
\hline $\mathrm{Zn}$ & 102 & 101 & 103 & 1.27 & 1.24 \\
\hline $\mathbf{G a}$ & 22.0 & 21.8 & 22.1 & 0.21 & 0.97 \\
\hline $\mathbf{R b}$ & 9.2 & 9.1 & 9.4 & 0.13 & 1.42 \\
\hline $\mathrm{Sr}$ & 396 & 390 & 402 & 4.97 & 1.26 \\
\hline $\mathbf{Y}$ & 26.0 & 25.4 & 26.4 & 0.47 & 1.80 \\
\hline $\mathrm{Zr}$ & 170 & 167 & 172 & 2.65 & 1.56 \\
\hline $\mathrm{Nb}$ & 18.3 & 17.9 & 18.6 & 0.29 & 1.57 \\
\hline Mo & 3.80 & 3.59 & 3.97 & 0.12 & 3.14 \\
\hline Cs & 0.10 & 0.08 & 0.11 & 0.01 & 11.8 \\
\hline $\mathrm{Ba}$ & 131 & 125 & 135 & 3.45 & 2.63 \\
\hline La & 15.2 & 14.7 & 15.6 & 0.36 & 2.35 \\
\hline $\mathrm{Ce}$ & 37.6 & 37.0 & 38.2 & 0.58 & 1.54 \\
\hline $\mathrm{Pr}$ & 5.35 & 5.13 & 5.45 & 0.11 & 2.05 \\
\hline Nd & 24.5 & 23.9 & 25.0 & 0.47 & 1.93 \\
\hline Sm & 6.10 & 5.87 & 6.28 & 0.21 & 3.43 \\
\hline Eu & 2.07 & 1.97 & 2.13 & 0.08 & 3.79 \\
\hline Gd & 6.16 & 6.04 & 6.38 & 0.15 & 2.40 \\
\hline $\mathrm{Tb}$ & 0.92 & 0.91 & 0.95 & 0.02 & 2.03 \\
\hline Dy & 5.28 & 5.11 & 5.53 & 0.15 & 2.79 \\
\hline Ho & 0.98 & 0.96 & 0.99 & 0.02 & 1.55 \\
\hline $\mathrm{Er}$ & 2.56 & 2.42 & 2.63 & 0.09 & 3.70 \\
\hline $\mathrm{Tm}$ & 0.34 & 0.31 & 0.37 & 0.02 & 6.77 \\
\hline $\mathrm{Yb}$ & 2.02 & 1.92 & 2.12 & 0.11 & 5.44 \\
\hline Lu & 0.28 & 0.27 & 0.29 & 0.01 & 4.50 \\
\hline $\mathrm{Hf}$ & 4.33 & 4.17 & 4.47 & 0.15 & 3.48 \\
\hline $\mathrm{Ta}$ & 1.15 & 1.09 & 1.22 & 0.06 & 5.21 \\
\hline $\mathbf{w}$ & 0.23 & 0.19 & 0.27 & 0.04 & 15.48 \\
\hline $\mathrm{Pb}$ & 1.70 & 1.65 & 1.78 & 0.06 & 3.24 \\
\hline Th & 1.22 & 1.17 & 1.29 & 0.05 & 4.48 \\
\hline $\mathbf{U}$ & 0.40 & 0.39 & 0.42 & 0.02 & 4.10 \\
\hline
\end{tabular}


Table 3.0-8: List of measured and preferred values for trace element abundances of glass standard BCR-2. Reference values were obtained from Jochum \& Enzweiler (2014). All values are given in ppm.

\begin{tabular}{|c|c|c|c|c|c|c|c|}
\hline \multicolumn{8}{|c|}{$\begin{array}{c}\text { BCR-2 } \\
n=4\end{array}$} \\
\hline & Mean & Min & Max & $2 S D$ & 2 SD (\%) & Reference & $\%$ Offset \\
\hline Li & 9.2 & 9.02 & 9.4 & 0.3 & 3.1 & 9 & 2.5 \\
\hline Sc & 35.7 & 35.3 & 36.04 & 0.5 & 1.4 & 33 & 7.6 \\
\hline $\mathrm{Ti}$ & 14380 & 14290 & 14490 & 146 & 1.0 & 14100 & 1.9 \\
\hline $\mathbf{v}$ & 420 & 417 & 422 & 4.1 & 1.0 & 425 & -1.2 \\
\hline $\mathrm{Cr}$ & 16.2 & 15.6 & 17.1 & 1.2 & 7.5 & 17 & -4.9 \\
\hline$M n$ & 1573 & 1559 & 1592 & 27 & 1.7 & 1550 & 1.5 \\
\hline Co & 37.7 & 37.0 & 38.2 & 0.97 & 2.6 & 38 & -0.9 \\
\hline $\mathrm{Ni}$ & 11.8 & 11.6 & 12.1 & 0.4 & 3.2 & 13 & -10 \\
\hline $\mathrm{Cu}$ & 17.9 & 17.3 & 18.2 & 0.6 & 3.5 & 21 & -18 \\
\hline $\mathrm{Zn}$ & 137 & 134 & 140 & 5 & 3.4 & 125 & 8.6 \\
\hline $\mathbf{G a}$ & 23.8 & 23.6 & 24.0 & 0.3 & 1.4 & 23 & 3.3 \\
\hline $\mathbf{R b}$ & 48.3 & 47.7 & 48.6 & 0.74 & 1.5 & 47 & 2.6 \\
\hline $\mathrm{Sr}$ & 354 & 353 & 356 & 1.66 & 0.5 & 342 & 3.5 \\
\hline $\mathbf{Y}$ & 37.0 & 36.6 & 37.5 & 0.7 & 1.9 & 35 & 5.5 \\
\hline $\mathrm{Zr}$ & 192 & 190 & 193 & 2 & 1.0 & 184 & 4.0 \\
\hline $\mathrm{Nb}$ & 13.2 & 13.1 & 13.34 & 0.2 & 1.2 & 12.5 & 5.6 \\
\hline Mo & 241 & 237 & 245 & 6.22 & 2.6 & 270 & -12 \\
\hline Cs & 1.16 & 1.06 & 1.27 & 0.2 & 17 & 1.16 & -0.4 \\
\hline $\mathrm{Ba}$ & 713 & 709 & 717 & 8 & 1.1 & 683 & 4.2 \\
\hline La & 25.7 & 25.4 & 26 & 0.48 & 1.9 & 24.7 & 4.1 \\
\hline $\mathrm{Ce}$ & 55.4 & 54.8 & 56 & 0.9 & 1.6 & 53.3 & 3.9 \\
\hline $\operatorname{Pr}$ & 7.19 & 7.11 & 7.30 & 0.15 & 2.1 & 6.7 & 6.8 \\
\hline Nd & 29.9 & 29.1 & 30.7 & 1.2 & 4.1 & 28.9 & 3.2 \\
\hline $\mathrm{Sm}$ & 6.90 & 6.77 & 6.98 & 0.16 & 2.3 & 6.59 & 4.5 \\
\hline Eu & 2.02 & 1.94 & 2.09 & 0.11 & 5.3 & 1.97 & 2.6 \\
\hline Gd & 6.79 & 6.72 & 6.91 & 0.15 & 2.2 & 6.71 & 1.2 \\
\hline $\mathrm{Tb}$ & 1.09 & 1.00 & 1.13 & 0.10 & 9.2 & 1.02 & 6.3 \\
\hline Dy & 6.50 & 6.45 & 6.57 & 0.09 & 1.4 & 6.44 & 1 \\
\hline Ho & 1.35 & 1.31 & 1.38 & 0.06 & 4.1 & 1.3 & 5.6 \\
\hline $\mathrm{Er}$ & 3.76 & 3.70 & 3.87 & 0.13 & 3.4 & 3.7 & 1.7 \\
\hline $\mathrm{Tm}$ & 0.55 & 0.52 & 0.60 & 0.06 & 11 & 0.5 & 6.6 \\
\hline $\mathrm{Yb}$ & 3.58 & 3.38 & 3.70 & 0.24 & 6.6 & 3.39 & 5.2 \\
\hline Lu & 0.55 & 0.51 & 0.60 & 0.07 & 14 & 0.5 & 8.7 \\
\hline $\mathrm{Hf}$ & 5.03 & 4.80 & 5.24 & 0.32 & 6.4 & 4.8 & 3.8 \\
\hline Ta & 0.81 & 0.79 & 0.83 & 0.03 & 3.9 & 0.78 & 3.9 \\
\hline $\mathbf{w}$ & 0.53 & 0.49 & 0.56 & 0.06 & 11 & 0.5 & 6.1 \\
\hline $\mathrm{Pb}$ & 10.6 & 10.3 & 10.9 & 0.5 & 4.8 & 11 & -3.4 \\
\hline Th & 6.32 & 6.20 & 6.43 & 0.19 & 3.1 & 5.9 & 6.6 \\
\hline $\mathbf{U}$ & 1.65 & 1.58 & 1.68 & 0.08 & 4.9 & 1.69 & -2.7 \\
\hline
\end{tabular}


Table 3.0-9: List of measured and preferred values for trace element abundances of glass standard NIST612G. Reference values were obtained from Jochum \& Enzweiler (2014). All values are given in ppm.

\begin{tabular}{|c|c|c|c|c|c|c|c|}
\hline \multicolumn{8}{|c|}{$\begin{array}{c}\text { NIST612 } \\
n=30\end{array}$} \\
\hline & Mean & Min & Max & $2 S D$ & 2 SD (\%) & Reference & $\%$ Offset \\
\hline Li & 40.7 & 39.5 & 41.9 & 1.3 & 3.2 & 40.2 & 1.3 \\
\hline Sc & 45.1 & 43.8 & 47.1 & 2.1 & 4.7 & 39.9 & 11.6 \\
\hline $\mathrm{Ti}$ & 47.2 & 45.6 & 49.4 & 2.0 & 4.3 & 44.0 & 6.8 \\
\hline $\mathbf{v}$ & 39.4 & 38.6 & 40.7 & 1.3 & 3.2 & 38.8 & 1.6 \\
\hline $\mathrm{Cr}$ & 38.1 & 35.1 & 43.3 & 3.2 & 8.5 & 36.4 & 4.6 \\
\hline Mn & 43.6 & 42.0 & 46.4 & 2.4 & 5.5 & 38.7 & 11.2 \\
\hline Co & 35.3 & 34.6 & 36.2 & 0.9 & 2.5 & 35.5 & -0.6 \\
\hline $\mathrm{Ni}$ & 38.0 & 37.3 & 39.4 & 1.1 & 3.0 & 38.8 & -2.0 \\
\hline $\mathrm{Cu}$ & 40.2 & 36.5 & 44.8 & 4.8 & 11.8 & 37.8 & 6.0 \\
\hline $\mathrm{Zn}$ & 31.3 & 29.6 & 32.9 & 1.7 & 5.5 & 39.1 & -25.0 \\
\hline Ga & 39.6 & 38.4 & 40.7 & 1.1 & 2.8 & 36.9 & 6.7 \\
\hline $\mathbf{R b}$ & 32.5 & 31.7 & 33.6 & 1.1 & 3.5 & 31.4 & 3.3 \\
\hline Sr & 88.2 & 86.1 & 92.1 & 3.4 & 3.8 & 78.4 & 11.1 \\
\hline $\mathbf{Y}$ & 46.8 & 45.3 & 49.2 & 2.7 & 5.7 & 38.3 & 18.1 \\
\hline $\mathrm{Zr}$ & 45.0 & 43.6 & 47.5 & 2.4 & 5.3 & 37.9 & 15.7 \\
\hline $\mathrm{Nb}$ & 44.4 & 43.5 & 46.1 & 1.4 & 3.2 & 38.9 & 12.4 \\
\hline Mo & 35.2 & 32.6 & 37.1 & 2.0 & 5.8 & 37.4 & -6.3 \\
\hline Cs & 44.6 & 39.6 & 51.8 & 5.1 & 11.4 & 42.7 & 4.2 \\
\hline $\mathrm{Ba}$ & 43.2 & 42.1 & 46.4 & 1.9 & 4.5 & 39.3 & 9.0 \\
\hline La & 40.6 & 39.5 & 42.9 & 2.2 & 5.4 & 36.0 & 11.4 \\
\hline $\mathrm{Ce}$ & 43.1 & 42 & 45.5 & 2.0 & 4.6 & 38.4 & 10.9 \\
\hline $\mathrm{Pr}$ & 43.8 & 42.5 & 46.6 & 2.4 & 5.5 & 37.9 & 13.5 \\
\hline $\mathrm{Nd}$ & 40.8 & 39.1 & 43.7 & 2.4 & 6.0 & 35.5 & 13.0 \\
\hline $\mathrm{Sm}$ & 42.9 & 41.4 & 45.2 & 2.5 & 5.8 & 37.7 & 12.2 \\
\hline Eu & 40.4 & 39.4 & 42.3 & 1.9 & 4.7 & 35.6 & 11.8 \\
\hline Gd & 43.6 & 41.7 & 47 & 3.0 & 6.9 & 37.3 & 14.5 \\
\hline $\mathrm{Tb}$ & 44.1 & 42.3 & 48.2 & 3.5 & 7.9 & 37.6 & 14.7 \\
\hline Dy & 41.1 & 39.7 & 43.8 & 2.4 & 5.8 & 35.5 & 13.7 \\
\hline Ho & 44.0 & 42.7 & 47.5 & 2.6 & 5.9 & 38.3 & 12.9 \\
\hline $\mathrm{Er}$ & 44.4 & 43.0 & 46.9 & 2.8 & 6.3 & 38.0 & 14.3 \\
\hline $\mathrm{Tm}$ & 44.7 & 41.7 & 47.5 & 2.9 & 6.5 & 36.8 & 17.6 \\
\hline $\mathrm{Yb}$ & 44.7 & 42.8 & 47.7 & 3.0 & 6.7 & 39.2 & 12.4 \\
\hline Lu & 43.0 & 40.4 & 49.5 & 4.1 & 9.6 & 37.0 & 13.9 \\
\hline $\mathrm{Hf}$ & 41.3 & 39.9 & 44.5 & 2.8 & 6.7 & 36.7 & 11.1 \\
\hline $\mathrm{Ta}$ & 44.9 & 43.4 & 48.1 & 2.6 & 5.7 & 37.6 & 16.2 \\
\hline $\mathbf{w}$ & 41.1 & 38.6 & 43.9 & 2.3 & 5.6 & 38.0 & 7.5 \\
\hline $\mathrm{Pb}$ & 39.1 & 37.8 & 41.6 & 1.9 & 4.9 & 38.6 & 1.5 \\
\hline Th & 43.6 & 42.0 & 47.2 & 3.2 & 7.4 & 37.8 & 13.2 \\
\hline $\mathbf{U}$ & 38.8 & 36.9 & 41.3 & 2.4 & 6.1 & 37.4 & 3.6 \\
\hline
\end{tabular}




\subsection{Fractionation corrections}

Post-entrapment olivine crystallization of melt inclusions along the host wall is common during eruptive cooling. Therefore, composition adjustments are required to account for element depletion (or enrichment) in the melt inclusion caused by postentrapment crystallization. This most strongly affects to elements strongly enriched within the host crystal, such as Mg in olivine (Luhr, 2001). Using the method of Luhr (2001), host olivine composition was iteratively added to the melt inclusion glass major element composition until an olivine-melt $\mathrm{K}_{D}{ }^{\mathrm{Fe}-\mathrm{Mg}}$ of 0.3 was reached (Roeder and Emslie, 1970).

$$
K_{D}=\frac{\left(X_{F e O}^{O l}\right)}{\left(X_{F e O}^{L i q}\right)} \frac{\left(X_{M g O}^{L i q}\right)}{\left(X_{M g O}^{O l}\right)}
$$

These calculations require $\mathrm{Fe}^{2+}$, however as no olivine hosted spinel grains were analysed, due to an absence of observed spinel, $\mathrm{Fe}^{2+} / \mathrm{Fe}^{3+}$ proportions were unable to be accurately determined on a sample basis. A conservative $\mathrm{Fe}^{2+} / \mathrm{Fe}^{3+}$ ratio of 0.85/0.15 was used to determine $\mathrm{Fe}^{2+}$ from $\mathrm{Fe}^{\mathrm{t}}$ as measured from EPMA analysis. This ratio was selected on the basis of reported measurements of Kermadec Arc samples (Gamble et al., 1993a). During reintegration of olivine into melt inclusions, both $\mathrm{H}_{2} \mathrm{O}$ and $\mathrm{CO}_{2}$ contents as measured by FTIR were added after a $\mathrm{K}_{\mathrm{D}}$ of 0.3 was reached. All major element data discussed has been processed using this method, see appendix $C$ for final melt compositions.

Major elements were modelled following a reverse crystallising trend to an MgO of 8 wt.\% (e.g., Taylor \& Martinez, 2003). This was useful for investigating source variations that required the removal of compositional variance due to fractional crystallisation.

$\mathrm{FeO}, \mathrm{Na}_{2} \mathrm{O}$, and $\mathrm{TiO}_{2}$ concentrations, were modelled to $8 \mathrm{wt} . \% \mathrm{MgO}$ values following the methods of Taylor \& Martinez (2003), using the equations:

$$
F e_{8}=\frac{[F e O+8-M g O]}{[1+0.25(8-M g O)]}
$$




$$
\begin{gathered}
\mathrm{Na}_{8}=\frac{\left[\mathrm{Na}_{2} \mathrm{O}+0.115(8-\mathrm{MgO})\right]}{[1+0.133(8-\mathrm{MgO})]} \\
\mathrm{Ti} i_{8}=\frac{\left(\mathrm{TiO}_{2}\right)(\mathrm{MgO})^{1.7}}{34.3}
\end{gathered}
$$

Trace metal ( $\mathrm{Cu}, \mathrm{Zn}, \mathrm{V}$, and $\mathrm{Pb}$ ) abundances at $8 \mathrm{wt} . \% \mathrm{MgO}$ were calculated using Petrolog 3.1.1.3 (Danyushevsky and Plechov, 2011). Only melt inclusion compositions were modelled to avoid effects of plagioclase fractionation that will have affected groundmass glasses. A constant pressure of $1 \mathrm{Kbar}$ was set, based on a calculated magma chamber pressure from Wysoczanski et al. (2012). Fractionating minerals included were olivine, clinopyroxene and spinel, using models from Danyushevsky \& Plechov (2011) and Nielsen (1985). As some samples had $\mathrm{Cr}_{2} \mathrm{O}_{3}$ contents, as measured by EPMA, that were too low for the purpose of modelling early spinel fractionation, $0.001 \mathrm{wt} . \%$ was added to allow for modelling of spinel fractionation. On the basis of $\mathrm{CaO}, \mathrm{Al}_{2} \mathrm{O}_{3}$ and $\mathrm{FeO}$ vs $\mathrm{MgO}$ systematics in the sample glasses, clinopyroxene was included with olivine and spinel in reverse crystallisation modelling to reach $7 \mathrm{wt} . \% \mathrm{MgO}$, after which it was excluded.

Trace metal $K_{D}$ values were sourced from the GERM Partition Coefficient $\left(K_{D}\right)$ Database for bulk compositions appropriate to the samples. Molybdenum was excluded due to lack of relevant partition coefficients for olivine, clinopyroxene, and plagioclase in basaltic magmas. $K_{D}$ values used were an average of suitable values, summarised in table 3.0-10-12.

\begin{tabular}{|c|c|c|}
\hline \multicolumn{3}{|c|}{ Olivine } \\
\hline Element & $K_{D}$ & Reference \\
\hline $\mathrm{Cu}$ & 0.0665 & $\begin{array}{l}\text { Bougault and Hekinian, } \\
\text { (1974); Paster et al., (1974) }\end{array}$ \\
\hline $\mathrm{Zn}$ & 0.83 & $\begin{array}{l}\text { Bougault \& Hekinian, (1974); } \\
\text { Kloeck \& Palme, (1988) }\end{array}$ \\
\hline V & 0.088 & Bougault \& Hekinian, (1974) \\
\hline $\mathrm{Pb}$ & 0.0001 & $\begin{array}{l}\text { McKenzie and O'Nions, } \\
\text { (1991) }\end{array}$ \\
\hline
\end{tabular}

Table 3.0-10: $\mathrm{K}_{\mathrm{D}}$ values used for trace metals in olivine during modelling using Petrolog. 
Table 3.0-11: $K_{D}$ values used for trace metals in clinopyroxene during modelling using Petrolog.

\begin{tabular}{|c|c|c|}
\hline \multicolumn{3}{|c|}{ Clinopyroxene } \\
\hline Element & $K_{D}$ & Reference \\
\hline $\mathrm{Cu}$ & 0.2036 & $\begin{array}{l}\text { Bougault \& Hekinian, (1974); } \\
\text { Hart \& Dunn, (1993); } \\
\text { Paster et al., (1974) }\end{array}$ \\
\hline $\mathrm{Zn}$ & 0.46 & $\begin{array}{l}\text { Bougault and Hekinian, } \\
\text { (1974); Paster et al., (1974); } \\
\text { Matsui et al., (1977) }\end{array}$ \\
\hline $\mathrm{V}$ & 2.6175 & $\begin{array}{l}\text { Bougault and Hekinian, } \\
\text { (1974); Hart and Dunn, } \\
\text { (1993); Jenner et al., (1993); } \\
\text { Hauri et al., (1994) }\end{array}$ \\
\hline $\mathrm{Pb}$ & 0.01202 & Hauri et al., (1994) \\
\hline
\end{tabular}

Table 3.0-12: $\mathrm{K}_{\mathrm{D}}$ values used for trace metals in plagioclase during modelling using Petrolog.

\begin{tabular}{|c|c|l|}
\hline \multicolumn{2}{|c|}{ Plagioclase } \\
\hline Element & $K_{D}$ & \multicolumn{1}{|c|}{ Reference } \\
\hline $\mathrm{Cu}$ & 0.087 & $\begin{array}{l}\text { Bougault \& Hekinian, (1974); } \\
\text { Paster et al., (1974) }\end{array}$ \\
\hline $\mathrm{Zn}$ & 0.14 & $\begin{array}{l}\text { Bougault and Hekinian, } \\
\text { (1974); Paster et al., (1974); } \\
\text { Kravuchuk et al., (1981) }\end{array}$ \\
\hline $\mathrm{V}$ & 0.1 & Bougault \& Hekinian, (1974) \\
\hline $\mathrm{Pb}$ & 0.56 & $\begin{array}{l}\text { Kravuchuk et al., (1981); } \\
\text { McKenzie \& O'Nions, (1991) }\end{array}$ \\
\hline
\end{tabular}


Chapter 4: Results 


\subsection{Rock Descriptions}

All analysed samples are porphyritic and vesicular with mineral compositions of olivine + pyroxene and plagioclase. The volume proportions of phenocrysts, vesicles, and groundmass vary between samples. All samples share characteristic glassy outer rim where the erupted lava was rapidly quenched. Glassy edges contain similar phenocryst assemblages and proportions to the interior portions, excluding potential microcrystal growth following emplacement. Groundmass material consists of devitrified glass and acicular plagioclase microcrystals. Additionally, samples display variable secondary alteration or mineral-crusted margins. The volume of these secondary margins are not included in total volume percent (vol.\%) of the rock samples.

Table 4.0-1: Table of rock sample primary characteristics, including phenocryst total and individual abundance (vol.\%), vesicularity (vol.\%), and secondary alteration.

\begin{tabular}{|c|c|c|c|c|c|c|}
\hline Name & $\begin{array}{c}\text { Phenocryst } \\
\text { vol. } \%\end{array}$ & $\begin{array}{c}\text { Olivine } \\
\text { vol.\% }\end{array}$ & $\begin{array}{c}\text { Clinopyroxene } \\
\text { vol.\% }\end{array}$ & $\begin{array}{c}\text { Plagioclase } \\
\text { vol.\% }\end{array}$ & $\begin{array}{c}\text { Vesicularity } \\
\text { vol.\% }\end{array}$ & $\begin{array}{l}\text { Secondary } \\
\text { alteration }\end{array}$ \\
\hline RIIW-1 & $25-30$ & $\begin{array}{l}\checkmark \\
6\end{array}$ & $\begin{array}{l}\checkmark \\
4\end{array}$ & $\begin{array}{l}\checkmark \\
90\end{array}$ & $25-30$ & $\begin{array}{l}\text { Red-brown } \\
\text { alteration }\end{array}$ \\
\hline RIIW-2 & 20 & $\begin{array}{c}\checkmark \\
5-7\end{array}$ & $\begin{array}{l}\checkmark \\
2\end{array}$ & $\begin{array}{c}\boldsymbol{V} \\
85-90\end{array}$ & $30-40$ & $\begin{array}{l}\text { Minimal red- } \\
\text { brown } \\
\text { alteration }\end{array}$ \\
\hline RIIW-3 & $25-30$ & $\begin{array}{l}\checkmark \\
13\end{array}$ & $\begin{array}{l}\checkmark \\
2\end{array}$ & $\begin{array}{c} \\
80-85\end{array}$ & 35 & $\begin{array}{l}\text { Red-brown } \\
\text { alteration }\end{array}$ \\
\hline Basin I & $35-40$ & $\begin{array}{l}\checkmark \\
15\end{array}$ & $\begin{array}{l}\checkmark \\
15\end{array}$ & $\begin{array}{l}\checkmark \\
70\end{array}$ & $10-15$ & $\begin{array}{c}5-8 \mathrm{~mm} \text { brown } \\
\text { - orange } \\
\text { mineral crusts }\end{array}$ \\
\hline Basin D & 20 vol.\% & $\begin{array}{c}\checkmark \\
4-5\end{array}$ & $\begin{array}{c} \\
1-3\end{array}$ & $\begin{array}{c}\checkmark \\
80-90\end{array}$ & 20 & $\begin{array}{l}\text { Minor orange- } \\
\text { brown crust }\end{array}$ \\
\hline RIII-1 & 3 vol.\% & $\begin{array}{c}\checkmark \\
2-3\end{array}$ & $\begin{array}{c}\checkmark \\
2-3\end{array}$ & $\begin{array}{c}\checkmark \\
90-95\end{array}$ & $<5$ & $\begin{array}{l}\text { Minimal light- } \\
\text { brown } \\
\text { alteration }\end{array}$ \\
\hline RIII-2 & $3-5$ & $\begin{array}{c}\checkmark \\
5-7\end{array}$ & $\begin{array}{c}\checkmark \\
2-3\end{array}$ & $\begin{array}{c}\checkmark \\
85-90\end{array}$ & 10 & N/A \\
\hline
\end{tabular}




\section{RIIW-1: TAN1104 ES11C}

Sample location:

On bottom: $35.354^{\circ} \mathrm{S} / 178.524^{\circ} \mathrm{E}$ at $1150 \mathrm{mbsl}$

Off bottom: $35.362^{\circ} \mathrm{S} / 178.519^{\circ} \mathrm{E}$ at $1440 \mathrm{mbsl}$

Sampling equipment used: epibenthic sled

Dark grey, vesicular, with a porphyritic texture. Phenocrysts are generally $0.8-$ $1 \mathrm{~mm}$ in size, with the smallest being $0.3 \mathrm{~mm}$. The phenocryst assemblage contains plagioclase + olivine + clinopyroxene. Plagioclase is the most abundant phenocryst phase, comprising $80-90 \%$ vol. $\%$ of phenocrysts, ranging in sizes from $0.25-1 \mathrm{~mm}$. Olivine and pyroxene phenocrysts are similarly sized, ranging from $\sim 0.3-0.8 \mathrm{~mm}$ and occur in proportions of approximately 6 vol. $\%$ and 4 vol. $\%$ of phenocrysts, respectively. Collectively phenocrysts compose $\sim 27$ vol.\% of the rock. Vesicles are predominately 3 $-4 \mathrm{~mm}$ but range from $1-5 \mathrm{~mm}$ and constitute $\sim 27 \mathrm{vol} . \%$ of the sample. Groundmass material comprises $\sim 45$ vol.\% of the sample. The outer $1-2 \mathrm{~mm}$ of the samples are altered with a red-brown crust.

\section{$\underline{\text { RIIW-2: TAN1104 ES16B }}$}

Sample location:

On bottom: $35.352^{\circ} \mathrm{S} / 178.529^{\circ} \mathrm{E}$ at $1165 \mathrm{mbsl}$

Off bottom: $35.358^{\circ} \mathrm{S} / 178.529^{\circ} \mathrm{E}$ at $1452 \mathrm{mbsl}$

Sampling equipment used: epibenthic sled

Dark grey, vesicular, with a porphyritic texture. Phenocrysts range in size from 0.7-1 mm. Plagioclase, olivine, and clinopyroxene compose the phenocryst assemblage. Plagioclase phenocrysts are $<1 \mathrm{~mm}$ in size, and are $\sim 85$ vol.\% of phenocrysts. Olivine crystals range from $\sim 0.5-1 \mathrm{~mm}$, and make up $5-7$ vol.\% of phenocrysts. Pyroxene crystals are predominantly $<0.8 \mathrm{~mm}$ and $\sim 2$ vol.\% of phenocrysts. Together the phenocrysts approximately 20 vol.\% of the samples. Vesicles range in size from $\sim 0.3-10 \mathrm{~mm}$ but are generally $0.5-0.8 \mathrm{~mm}$ and 
combined constitute $\sim 30-40$ vol.\% of the sample. The total ground mass is $\sim 40$ vol.\%. The outer $1-3 \mathrm{~mm}$ the sample is glassy and minimally altered.

\section{RIIW-3 TAN1104 ES30C}

Sample location:

On bottom: $35.353^{\circ} \mathrm{S} / 178.537^{\circ} \mathrm{E}$ at $1306 \mathrm{mbsl}$

Off bottom: $35.353^{\circ} \mathrm{S} / 178.534^{\circ} \mathrm{E}$ at $1220 \mathrm{mbsl}$

Sampling equipment used: epibenthic sled

Dark grey - black, vesicular with a porphyritic texture. Maximum phenocryst size is $2-3 \mathrm{~mm}$ (plagioclase) but most are $0.5-1.5 \mathrm{~mm}$ in size. The mineral assemblage is dominated by plagioclase ( $~ 80-75$ vol.\% of phenocrysts) with minor amounts of olivine and clinopyroxene. Plagioclase phenocrysts range in size from 0.5 $1.5 \mathrm{~mm}$. Olivine phenocrysts are $0.5-1 \mathrm{~mm}$ in size, and make up 13 vol.\% of phenocrysts. Pyroxene phenocrysts are scarce, present as approximately 2 vol. $\%$ and are generally $\sim 0.8 \mathrm{~mm}$ sized grains. Combined, the phenocryst assemblage equates to $\sim 25-30$ vol.\% of the rock sample. Vesicles range from $0.5-4 \mathrm{~mm}$ in size but most range from $0.5-0.8 \mathrm{~mm}$. They make up $\sim 35$ vol.\% of the sample. Groundmass in the interior is glass free and comprised of microcrystals. The outer $8-10 \mathrm{~mm}$ of the sample is glass lustrous black, and make up 35 vol.\% of the sample. The edge of the rock sample ( $1-2 \mathrm{~mm})$ is glassy, and stained brown - red-brown.

\section{Basin I: TAN1513 40}

Sample location:

$35.316^{\circ} \mathrm{S} / 177.739^{\circ} \mathrm{E}$ at $2182 \mathrm{mbsl}$

Sampling equipment used: epibenthic sled

Dark grey, vesicular with a porphyritic texture. Phenocrysts range between 0.5 $-8 \mathrm{~mm}$. The phenocryst assemblage is dominated by pyroxene ( 70 vol.\% of phenocrysts), with grain sizes ranging from $2-8 \mathrm{~mm}$. Plagioclase and olivine occur in 
approximately equal amounts and both range from $\sim 0.5-1 \mathrm{~mm}$. Phenocrysts compose $35-40$ vol.\% of the rock sample. Vesicles $(10-15$ vol.\%) vary from $\sim 0.8-2$ $\mathrm{mm}$ but are mostly $0.8-1 \mathrm{~mm}$. Groundmass material is $\sim 40-45$ vol. $\%$ of the sample. The outer $3-5 \mathrm{~mm}$ of the sample is glassy. Rock samples are highly altered with thick (5-8 mm) mineralized, dark-brown - orange-brown crusts.

\section{Basin D: TAN1213 51-6}

Sample location:

$35.39^{\circ} \mathrm{S} / 178.225^{\circ} \mathrm{E}$ at $2840 \mathrm{mbsl}$

Sampling equipment used: epibenthic sled

Dark grey, vesicular (20 vol.\%) with a porphyritic texture. Phenocrysts are dominantly $0.4-1 \mathrm{~mm}$. Plagioclase phenocrysts are elongate, and are $80-90$ vol.\% of phenocrysts. Olivine phenocrysts are approximately $0.8-1.5 \mathrm{~mm}$ and $4-5$ vol.\% of phenocrysts. Pyroxene grains are similar sized to olivine phenocrysts but sparse (1 - 3 vol.\%). Collectively, phenocrysts are $\sim 20$ vol.\% of the rock sample. The remaining 60 vol.\% is microcrystalline groundmass with the outer $3-8 \mathrm{~mm}$ glassy groundmass. The sample is lightly strained with a $\sim 0.5 \mathrm{~mm}$ thick orange-brown crust.

\section{RIII-1: TAN1104 53-A}

Sample location:

On bottom: $35.739^{\circ} \mathrm{S} / 178.497^{\circ} \mathrm{E}$ at $275 \mathrm{mbsl}$

Off bottom: $35.737^{\circ} \mathrm{S} / 178.492^{\circ} \mathrm{E}$ at $470 \mathrm{mbsl}$

Sampling equipment used: epibenthic sled

Black - dark grey colour, with low vascularity ( $<5$ vol. $\%$ vesicles), and a microcrystalline texture. Phenocrysts range in size from $0.3-5 \mathrm{~mm}$ but are dominated by $1-5 \mathrm{~mm}$ sized grains. The mineral assemblage is dominated by plagioclase, with smaller amounts of olivine and pyroxene. Plagioclase (90-95 vol.\% of phenocrysts), range in size from $1-5 \mathrm{~mm}$. Olivine phenocrysts are $0.4-0.8 \mathrm{~mm}$ and make up $\sim 2-$ 
3 vol.\% of phenocrysts. Pyroxene is similarly present as $2-3$ vol.\% and are generally $<$ $1.5 \mathrm{~mm}$ in size. Collectively, phenocrysts are $\sim 3$ vol.\% of rock sample. Vesicle sizes range from $0.3-25 \mathrm{~mm}$, but most are $0.5-5 \mathrm{~mm}$. Groundmass is $85-90$ vol. $\%$ of sample with an outer $\sim 10 \mathrm{~mm}$ thick glass region. The sample is notably fresh with minimal light-brown alteration.

\section{RIII-2 TAN1104 55-A}

Sample location:

On bottom: $35.739^{\circ} \mathrm{S} / 178.497^{\circ} \mathrm{E}$ at $254 \mathrm{mbsl}$

Off bottom: $35.741^{\circ} \mathrm{S} / 178.494^{\circ} \mathrm{E}$ at $400 \mathrm{mbs}$

Sampling equipment used: epibenthic sled

This sample was only present as rock chips, therefore phenocryst and vesicle sizes are likely minimum estimates. It has a dark grey colour, is vesicular and has a microcrystalline texture. Phenocrysts are $0.5-1.5 \mathrm{~mm}$ in size with an assemblage of plagioclase, olivine, and pyroxene. Plagioclase phenocrysts make up approximately 85 -92 vol.\% of phenocrysts and range in size between $\sim 1-1.5 \mathrm{~mm}$. Olivine phenocrysts are mostly $0.4-1 \mathrm{~mm}$ in size and represent $5-7$ vol.\% of all phenocrysts. Pyroxene comprises $2-3$ vol.\% of phenocrysts and are $\sim 0.5-0.7 \mathrm{~mm}$ in size. Phenocrysts comprise approximately $3-5$ vol.\% of the sample. Vesicles ( 10 vol.\% of the sample) and are mostly $0.2-0.5 \mathrm{~mm}$ in size. The groundmass, comprises $85-90$ vol.\% of sample. Glassy are regions evident by notable portions of non-crystalline or minimally crystalline groundmass chips, likely the quenched outer portion of eruptive material.

\subsection{Olivine grains and associated melt inclusions:}

The olivine grains are generally colourless but rarely display a very slight yellow - brown colouration. Grains are relatively equant in shape unless they have been fractured during rock crushing, and may less commonly form glomerocrysts either with clinopyroxene or other olivine grains. Other than melt inclusions, some olivine grains contain mostly opaque mineral inclusions (e.g., spinel group minerals; figure 4.1B \& D). 
These are notably absent from the arc front olivine crystals from Rumble II West (RIIW$1,2, \& 3$ ) and Rumble III (RIII-1 \& 2) but are abundant in back-arc olivine grains from Basin D and also present, to a lesser extent in the back-arc Basin I samples. The opaque inclusions occur as single cubic opaque crystals or amalgamations of several cubic grains, positioned randomly throughout the olivine crystal.

Melt inclusions within the selected olivine crystals are predominantly glassy, brown in colour and positioned randomly within the grain (figure $4.1 \mathrm{~A}, \mathrm{~B}, \mathrm{C}, \mathrm{D}$ ). The shape of inclusions is typically spherical but may also occur as oval-shaped or rarely as combined inclusion network (figure 4.1 B). This contrasts with the positioning of melt inclusions within other phenocryst phases such as plagioclase, where inclusions are focussed along crystallographic faces (figure 4.1 E). Olivine hosted melt inclusions may extend outwards towards the crystal edge, likely due to movement along a fracture. Inclusions commonly contain vapour bubbles (sometimes two) representing the diffusion and entrapment of vapour phases within the melt inclusion.

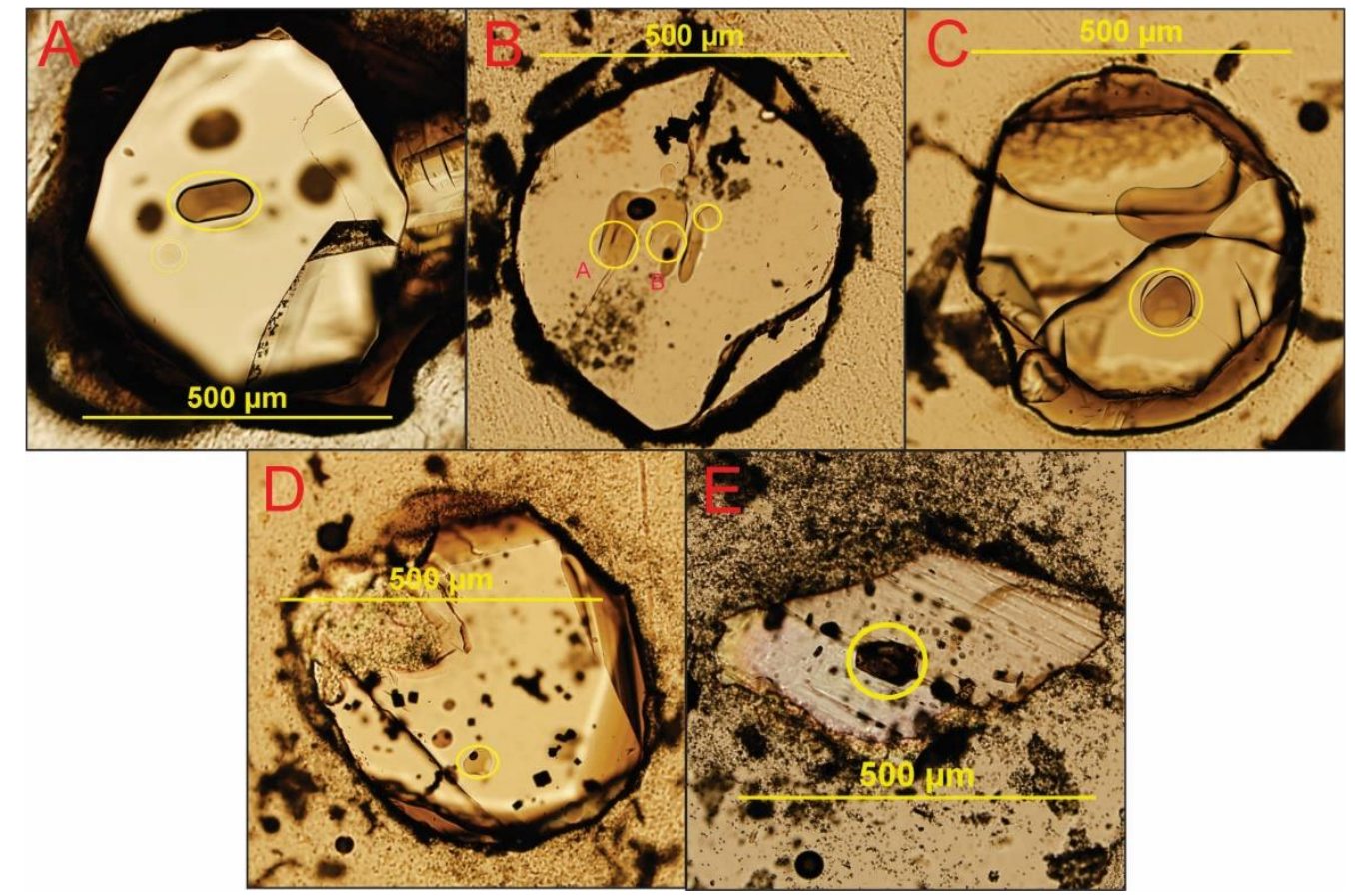

Figure 4.1: Plane polarised light photos of polished olivine grains (A, C, D, E) and a plagioclase grain (B) mounted in crystal-bond epoxy. Yellow circles identify exposed inclusions; only exposed surfaces are in focus. (A) RIIW-3 sample F, representing a typical olivine with melt inclusions. A transparent grain with randomly located spherical - oval melt inclusions. (B) Basin D sample E. olivine showing joined elongate inclusions as well as opaque mineral inclusion amalgamations. (C) RIIW-1 sample A. olivine showing a melt inclusion connected to the outer edge of the grain as well as a fully enclosed, exposed inclusion. (D) Basin D sample D. Olivine crystal with abundant opaque mineral inclusions. (E) A feldspar grain from RIIW-1, showing linear trends of melt inclusions along crystal/fracture planes. Fractures present in the photos are a result of polishing and were not present prior. 
Three zoning traits were observed within the olivine crystals; minor to moderate zoned rims, major compositional zoning, and olivine growth at the edges of the inclusion (figure $4.2,4.3, \& 4.4$ ). Most olivine samples have only minor zoned rims and inclusion edge olivine growth (e.g., figure 4.2). The thickness of the zoned rims varies from approximately $1 \mu \mathrm{m}-30 \mu \mathrm{m}$ (figure 4.2), whereby thick rims of $>15 \mu \mathrm{m}$ are only present in four of the analysed olivine grains (RIIW-1 samples F, J, K \& L). Furthermore, six olivine grains display larger-scale compositional zoning, as evident by EPMA imaging (figure 4.3, Basin-I samples A, E, Basin D samples D, G, H, \& RIIW-3 sample A). Composition zoning on the edge of melt inclusions (figure 4.4) indicates post-entrapment olivine crystallization on the edge of inclusions, these are typically $<1-2 \mu \mathrm{m}$ in width.

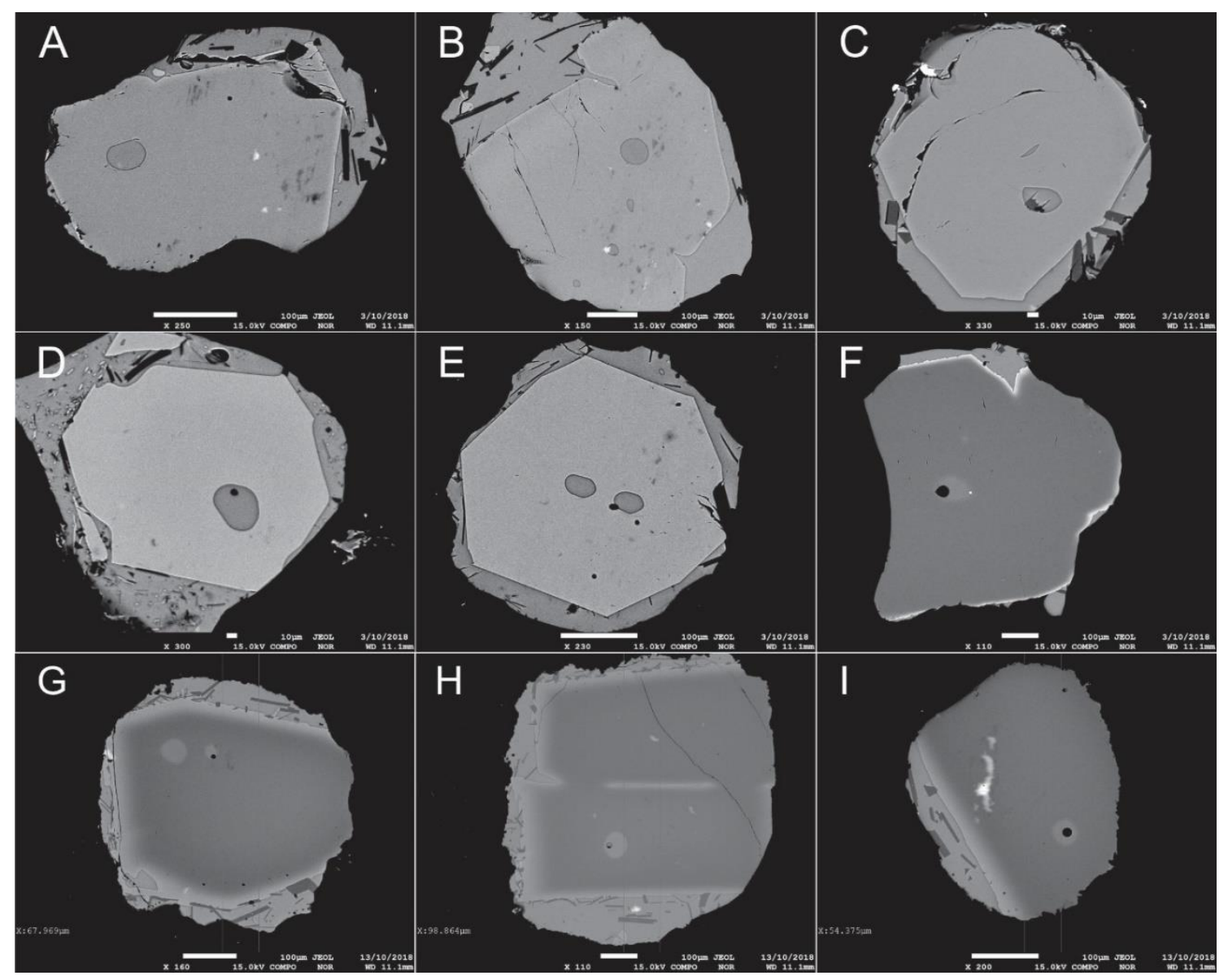

Figure 4.2: EPMA back-scatter imaging showing compositional variations in a selected range of olivine grains showing variable degree of rim compositional zoning. Zoning is evident by changes to lighter coloured regions around the edges. Darker regions beyond the olivine boundaries are vestigial glass salvages. Olivine samples included are: (A) RIIW-1 sample D, (B) RIIW-1 sample E, (C) RIIW-1 sample I, (D) RIIW-2 sample G, (E) RIII-2 sample G, (F) RIIW-1 sample F, (G) RIIW-1 sample J, (H) RIIW-1 sample K, (I) RIIW-1 sample L. Scales in each image are provided by the white bars at the bottom of each image, scales are $100 \mu \mathrm{m}$ except for C \& D which are $10 \mu \mathrm{m}$. 


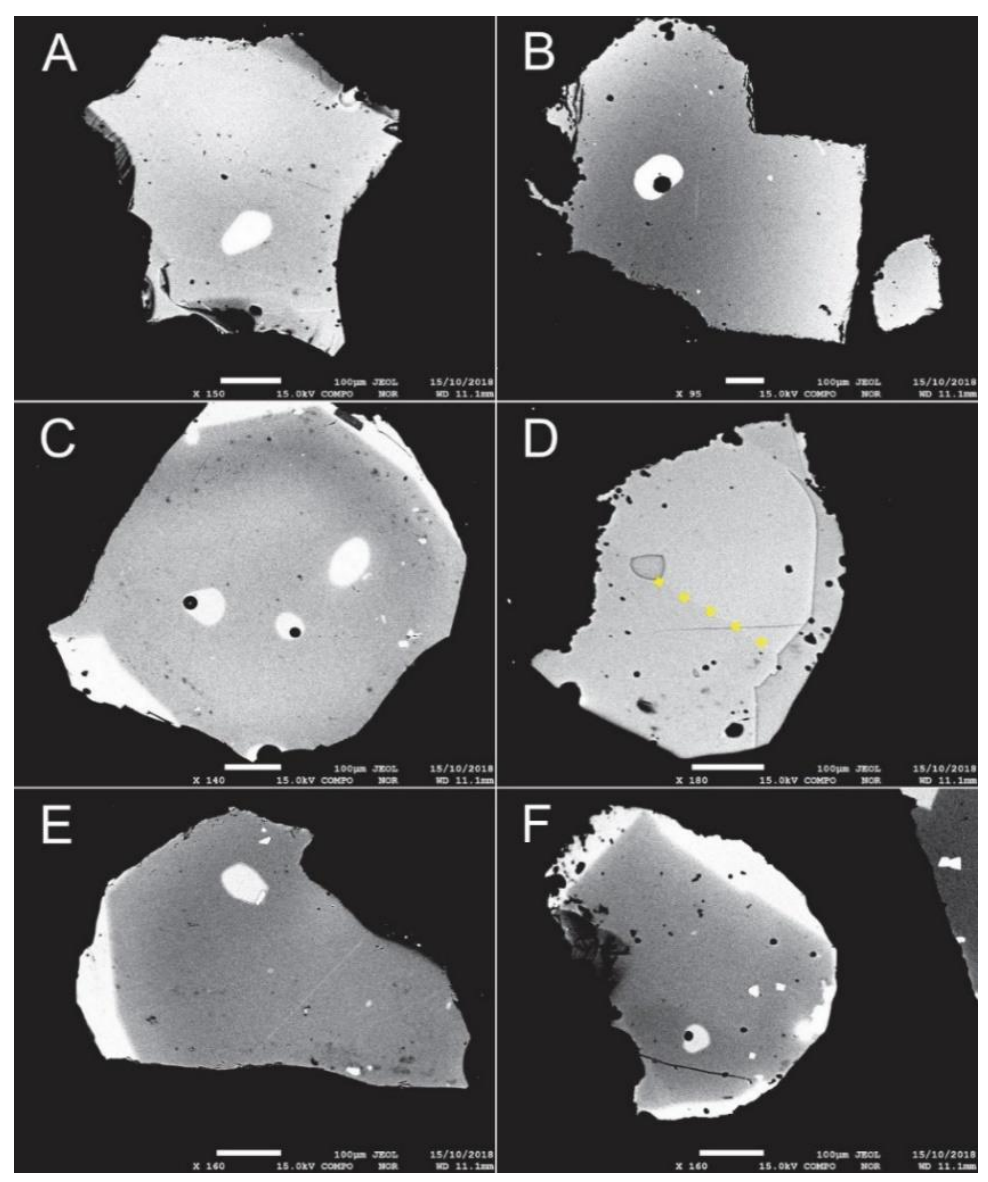

Figure 4.3: EPMA back-scatter imaging showing compositional variations in analysed olivine crystals that show larger scale compositional zones. Faint compositional zones are visible using relatively high contrast imaging. Compositional zones are evident by regions of variable shades of grey. (A) Basin I A, (B) Basin I E, (C) Basin D sample H, (D) RIIW-3 sample A, (E) Basin D sample G, (F) Basin sample D D. Scales in each photo are $100 \mu \mathrm{m}$. C, D, E, \& F feature vestigial glass salvages (bright edge regions). D) RIIW-3 sample A features a faint zonation, emphasised by yellow dashed line.

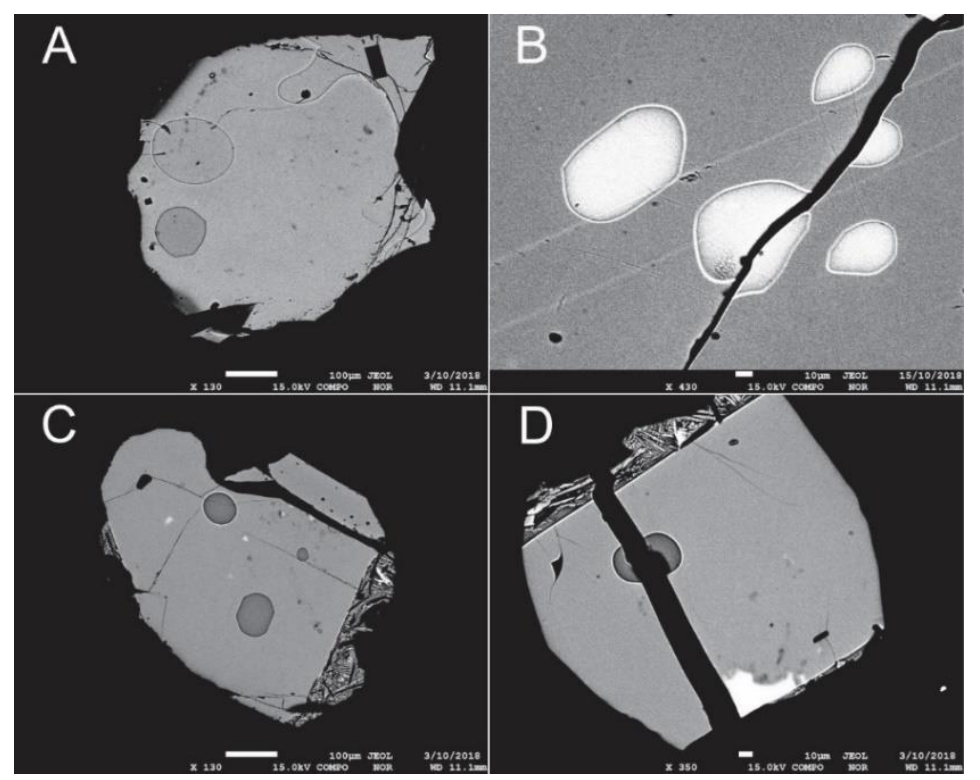

Figure 4.4: EPMA back-scatter imaging showing composition variations in analysed olivine crystals and melt inclusions. Bright halos around melt inclusions are post entrapment olivine growth rings. (A) RIIW-3 sample E, (B) Basin D sample E, (C) RIII-2 sample D, (D) RIII-2 sample H. Scale bars are 100 $\mu \mathrm{m}$ for $A \& C$, and $10 \mu \mathrm{m}$ for $B \& C$. 


\subsection{Groundmass Glass}

Groundmass glass material from all samples contain varying amounts of acicular plagioclase microcrystals, with Basin I showing the least ( $<5$ vol.\% whereas the other samples contain approximately $5-15$ vol.\% microcrystals). Vescularity varies from $<5-10$ vol.\% (Rumble II West \& Back-arc samples) to 30-40 vol.\% in Rumble III groundmass glasses (Figure 4.5).

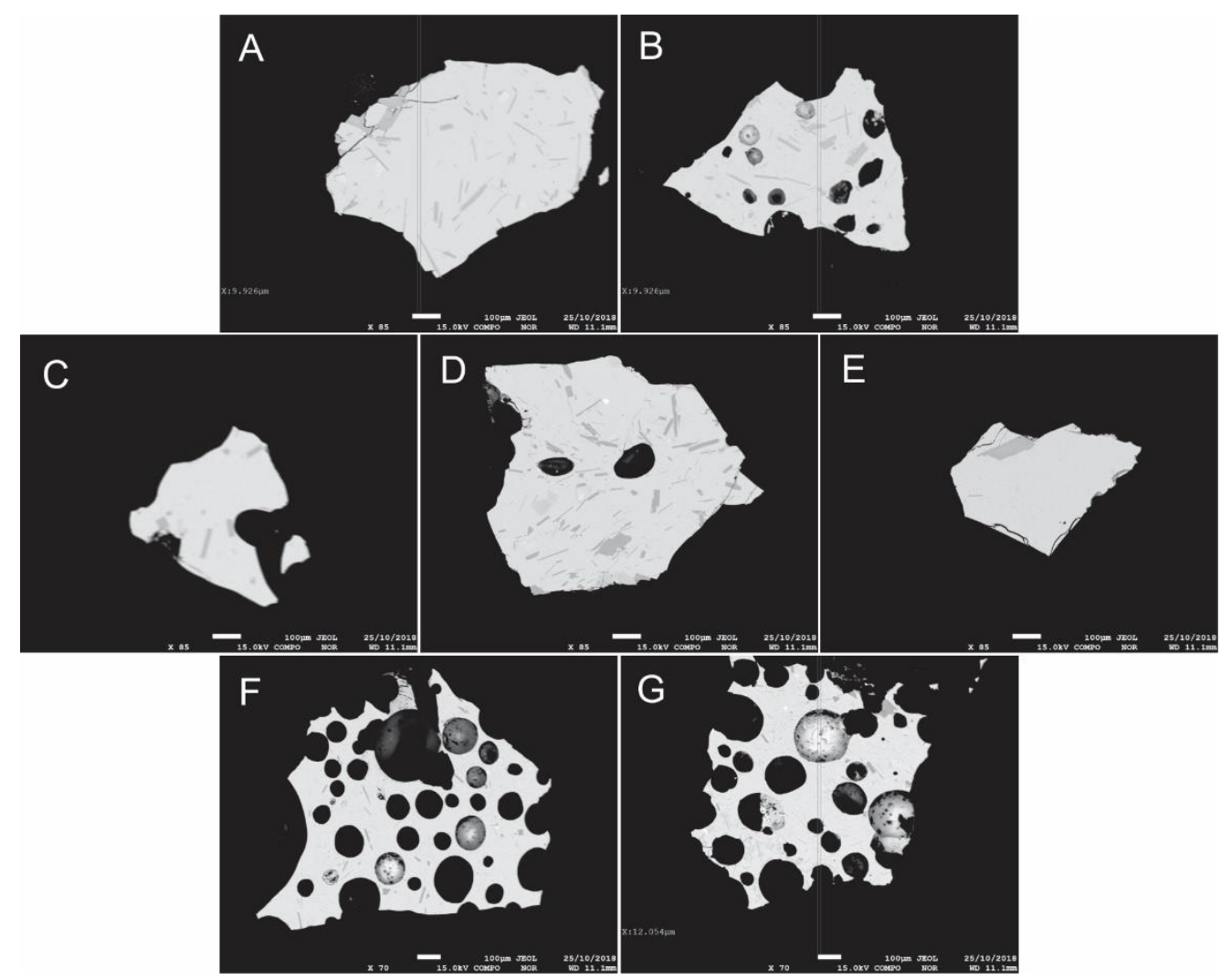

Figure 4.5: EPMA back-scatter imaging of representative groundmass glass shards. (A) RIIW-1, (B) RIIW2, (C) RIIW-3, (D) Basin D, (E) Basin I, (F) RIII-1, (G) RIII-2. Scale bars for all sample shards are $100 \mu \mathrm{m}$.

\subsection{Major element geochemistry}

All samples of both melt inclusions and groundmass glass are basaltic to basaltic-andesite in composition, following the classification of Le Maitre et al., (2002; $\sim 47.5-56.5$ wt.\% $\mathrm{SiO}_{2}$; Figure 4.6). The westernmost back arc sample, Basin I, is the only sample to be basaltic in composition for all glasses. Melt inclusions from all locations have higher $\mathrm{MgO}$ and lower $\mathrm{K}_{2} \mathrm{O}+\mathrm{Na}_{2} \mathrm{O}$ contents than their associated groundmass glass, consistent with fractionation of the melt. 


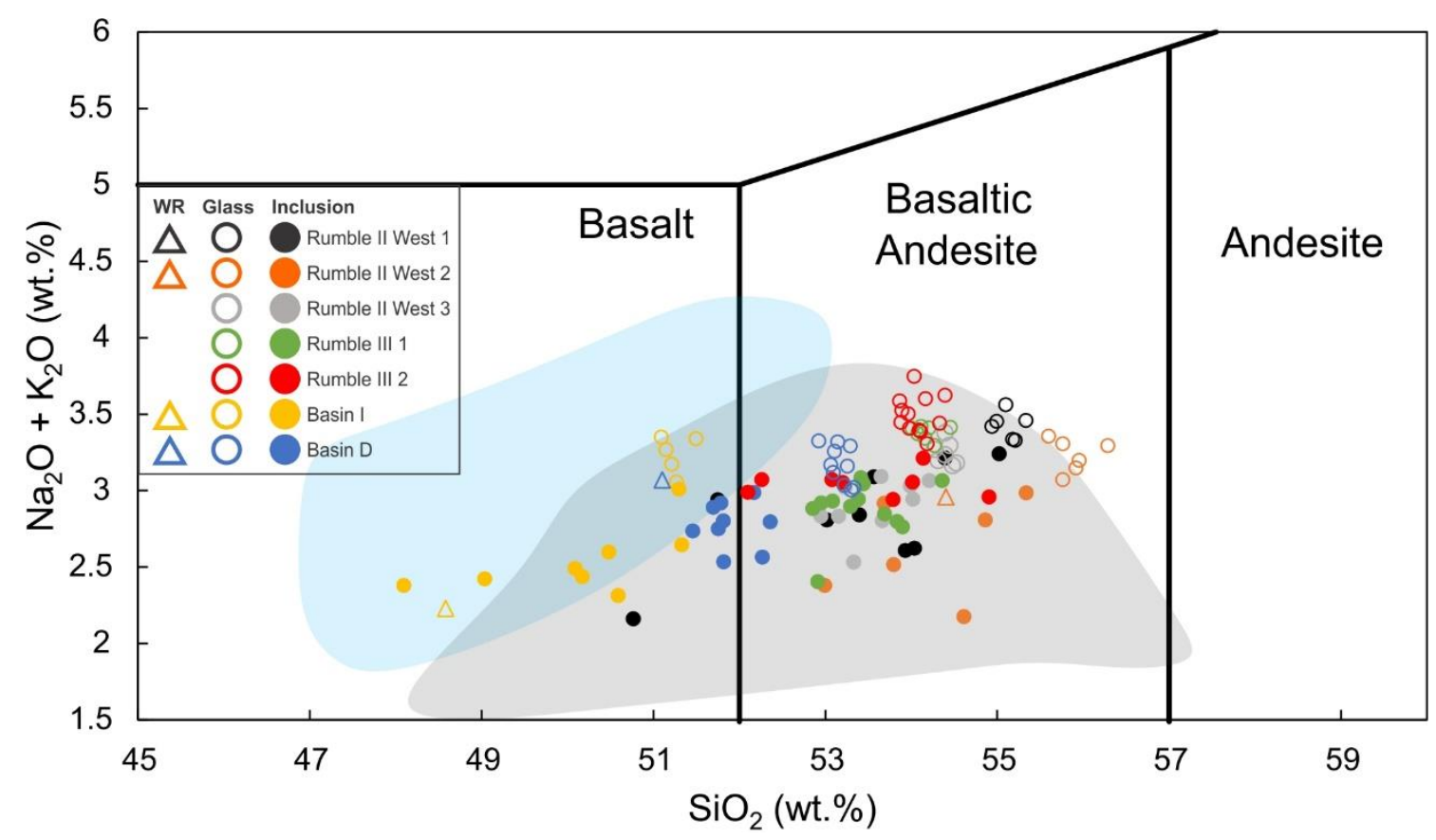

Figure 4.6: Silica vs total alkalis (TAS) diagram showing SKAHT samples investigated in this work. Light blue and grey fields represent SKAHT back-arc basin and arc front stratovolcano (Rumble II West, Rumble II East, Rumble III, and Rumble IV) whole rock compositions, respectively (Gamble et al., 1993c; Wright and Gamble, 1999; Haase et al., 2006; Pullan, 2018). Whole rock data for four samples are also shown (Timm et al., 2016; Pullan, 2018). Compositional fields are defined by Le Maitre et al. (2002).

In all samples $\mathrm{MgO}$ decreases with increasing $\mathrm{SiO}_{2}$ content (figure 4.7A), with the groundmass glasses showing the lowest $\mathrm{MgO}$, and highest $\mathrm{SiO}_{2}$ for each sample location, with the exception of Rumble III-2. Rumble III-2 samples show notable overlap between the groundmass glasses and melt inclusion compositions on all elemental plots. Overall, the back-arc samples have significantly higher $\mathrm{MgO}$ (lower $\mathrm{SiO}_{2}$ ) contents than the arc front samples with Basin D having higher $\mathrm{MgO}$ at a given $\mathrm{SiO}_{2}$ content than Basin I. In addition, Rumble III samples contain slightly lower $\mathrm{MgO}$ at a given $\mathrm{SiO}_{2}$ content than Rumble II West samples (figure 4.7A).

$\mathrm{FeO}_{\text {total }}$ correlations with $\mathrm{SiO}_{2}$ (and $\mathrm{MgO}$ ) differ between the arc front and backarc samples (figure $4.7 \mathrm{C}$ ). Arc front samples show a strong trend of decreasing $\mathrm{FeO}_{\text {total }}$ with increasing $\mathrm{SiO}_{2}$ (and decreasing $\mathrm{MgO}$ ), and generally contain higher $\mathrm{FeO}_{\text {total }}$ at a given $\mathrm{SiO}_{2}$ than the back-arc basins. RIIW-1 samples have a bimodal composition with inclusions split between compositions similar to either Basin D or the other Rumble II West samples. By contrast, the $\mathrm{FeO}_{\text {total }}$ composition of the back-arc samples is relatively consistent over increasing $\mathrm{SiO}_{2}$. Groundmass glasses of all samples are 
slightly offset to higher $\mathrm{FeO}_{\text {total }}$ at a given $\mathrm{SiO}_{2}$ relative to their respective melt inclusions (figure 4.7C).

Overall, $\mathrm{Al}_{2} \mathrm{O}_{3}$ shows a general slight decreasing trend with increasing $\mathrm{SiO}_{2}$ (and decreasing MgO; figure 4.7D). Within individual samples there are minimal decreases or variations in $\mathrm{Al}_{2} \mathrm{O}_{3}$ contents, however the groundmass glass compositions of most samples typically have higher $\mathrm{SiO}_{2}$ and lower $\mathrm{Al}_{2} \mathrm{O}_{3}$ than their respective melt inclusions. RIIW-1 samples however show a minor antithetic trend, with a slight increase in $\mathrm{Al}_{2} \mathrm{O}_{3}$ with increasing $\mathrm{SiO}_{2}$. $\mathrm{CaO}$, unlike $\mathrm{Al}_{2} \mathrm{O}_{3}$, decreases with increasing, most notably within the backarc samples (figure 4.7E). Basin D glasses have slightly higher $\mathrm{CaO}$ than $\mathrm{Basin} \mathrm{I}$ at a given $\mathrm{SiO}_{2}$ content, however $\mathrm{CaO}$ vs. $\mathrm{MgO}$ systematics show more scatter (not shown). Groundmass glass compositions generally have lower $\mathrm{CaO}$ contents than their respective melt inclusions.

$\mathrm{TiO}_{2}$ increases with increasing $\mathrm{SiO}_{2}$ and decreasing $\mathrm{MgO}$ for all samples (figure 4.7B). At comparable $\mathrm{SiO}_{2}$ values, Basin I samples have the highest $\mathrm{TiO}_{2}$ contents followed by Basin D, RIIW-1 and -2 and then RIII and RIIW-3 samples with equally low $\mathrm{TiO}_{2}$.

$\mathrm{K}_{2} \mathrm{O}$ contents increase with increasing $\mathrm{SiO}_{2}$ (figure 4.7H). However, most sample locations follow distinctly separate trends of $\mathrm{K}_{2} \mathrm{O}$ and $\mathrm{SiO}_{2}$. Basin I has the highest $\mathrm{K}_{2} \mathrm{O}$ content and is the only sample to be classified within the medium-K series (Gill, 1981). Rumble II West-1 and 2 samples have overlapping compositions following the same low- $\mathrm{K}_{2} \mathrm{O}$ trend versus $\mathrm{SiO}_{2}$. $\mathrm{RIIW}-3$ is distinct from the other two Rumble II West samples however, with higher $\mathrm{K}_{2} \mathrm{O}$ at a given $\mathrm{SiO}_{2}$, and plotting on a similar trend to that of Basin D, although at higher $\mathrm{SiO}_{2}$ values. Rumble III samples overlap with the highest $\mathrm{K}_{2} \mathrm{O}$ trend of those within the Low-K series. Basin I and D compositions are largely consistent with other back-arc basins, as too are arc front samples with arc front volcanoes (figure 4.7H). 

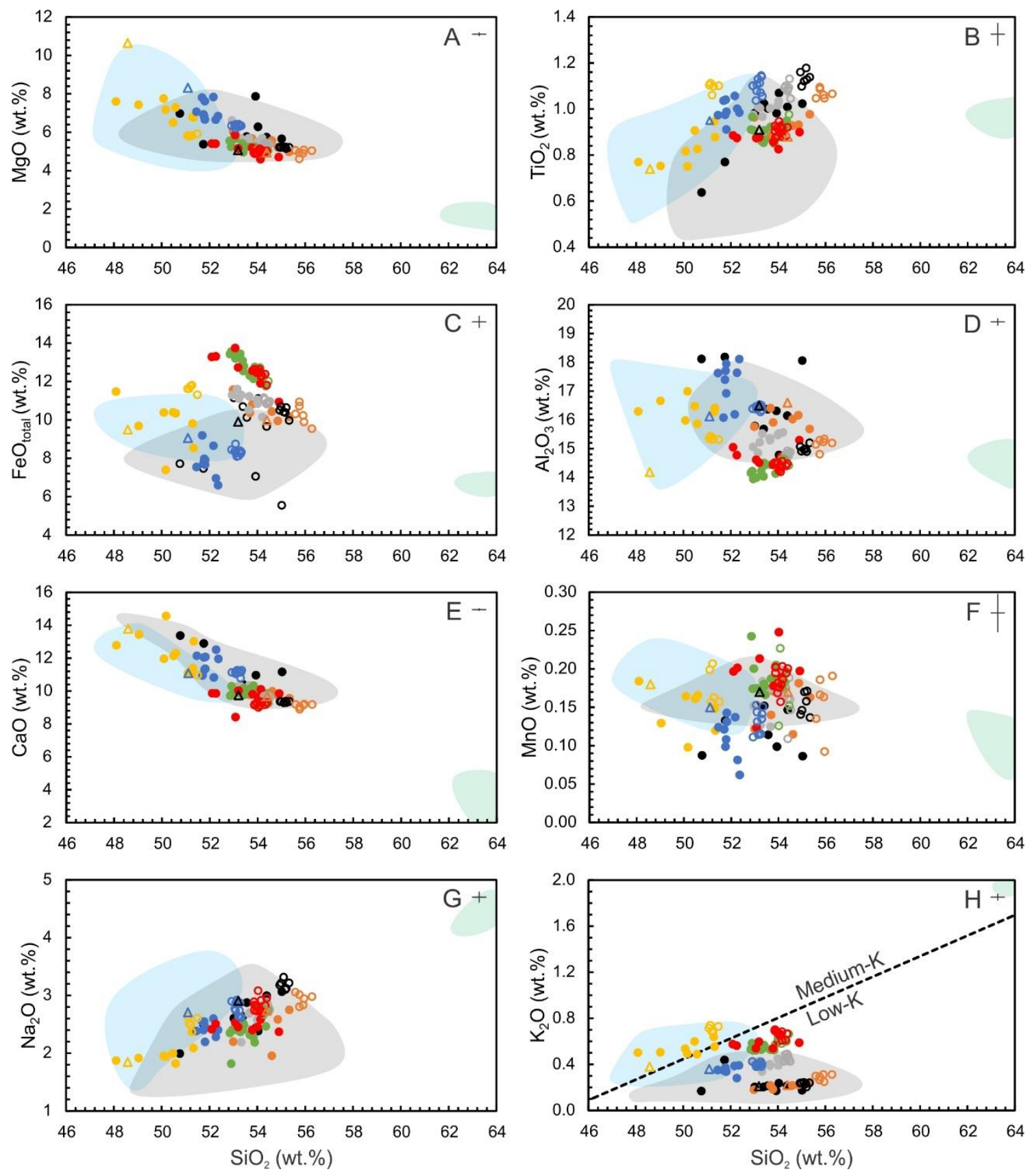

Figure 4.7: Bivariate diagrams of select major, minor and volatile elements plotted WR Glass Inclusion against $\mathrm{SiO}_{2}$, (A) MgO, (B) $\mathrm{TiO}_{2}$, (C) $\mathrm{FeO}_{\text {total, }}$ (D) $\mathrm{Al}_{2} \mathrm{O}_{3}$, (E) $\mathrm{CaO}$, (F) $\mathrm{MnO}$, (G) $\mathrm{Na}_{2} \mathrm{O}$, (H) $\mathrm{K}_{2} \mathrm{O}$, (I) $\mathrm{Cr}_{2} \mathrm{O}_{3},(\mathrm{~J}) \mathrm{S}_{\text {total }},(\mathrm{K}) \mathrm{Cl}$, and (L) $\mathrm{H}_{2} \mathrm{O}$. Light blue, grey, and green fields represent SKAHT back-arc basin, arc front stratovolcanoes (Rumble II West, Rumble II East, Rumble III, and Rumble IV), and Brothers volcano whole rock compositions, respectively (Gamble et al., 1993c; Wright and Gamble, 1999; Haase et al., 2006; Pullan, 2018). Whole rock samples of RIIW-1, RIIW-2, Basin I and Basin D are also shown (Timm et al., 2012; Pullan, 2018) Compositions for Brothers volcano are included to represent more evolved southern $\mathrm{KA}$ volcanic front magmas. $\mathrm{K}_{2} \mathrm{O}$

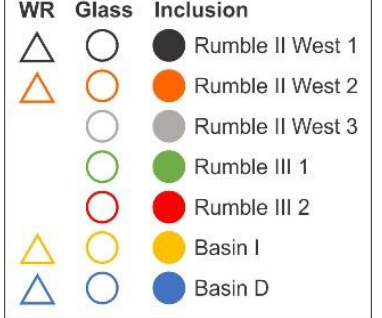
classification scheme from Gill (1981). Errors (2 SD) are given in the top right hand corner of each plot. 

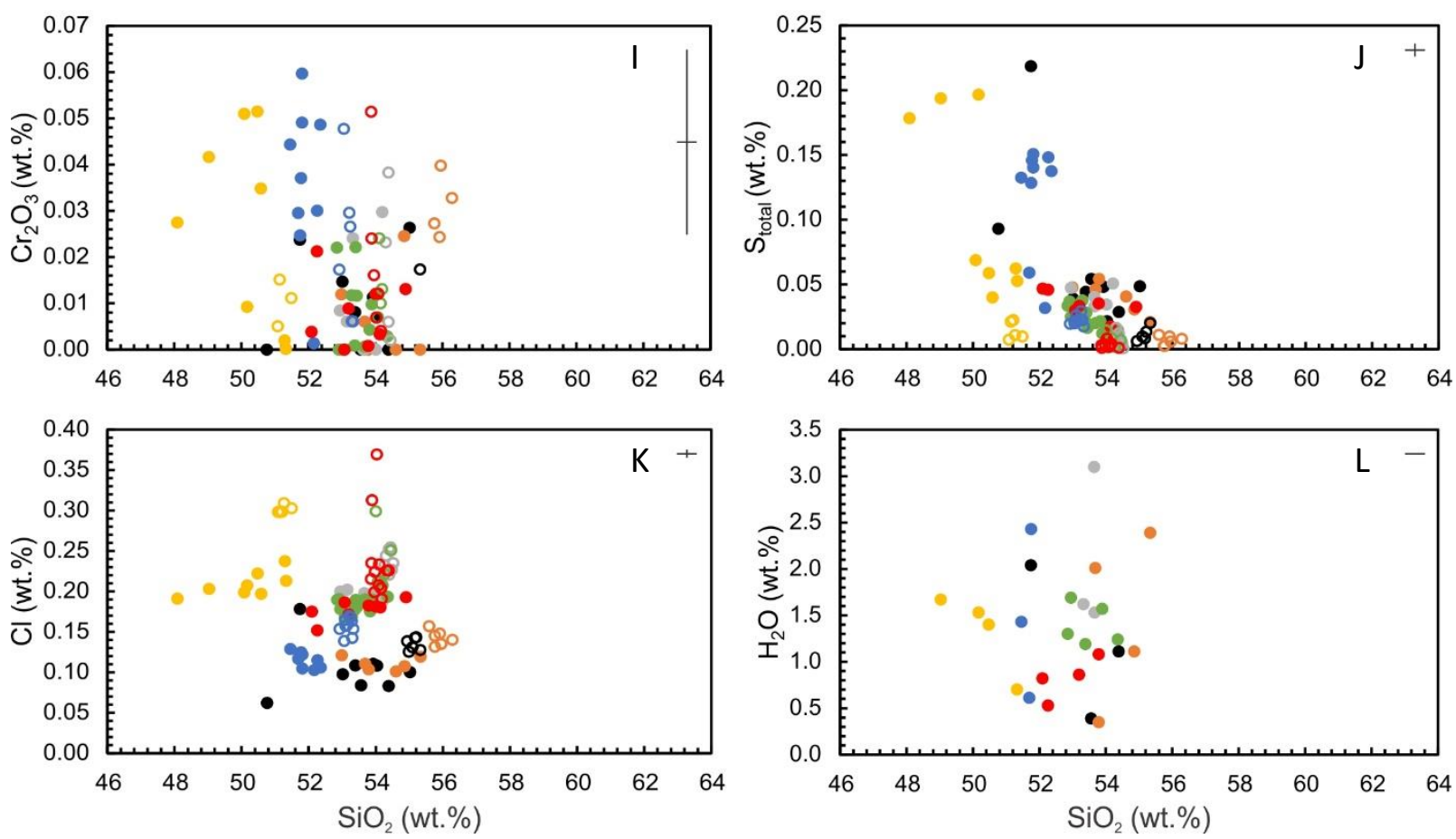

Figure 4.7 Continued.

Collectively, all samples display a clear increase in $\mathrm{Na}_{2} \mathrm{O}$ content with increasing $\mathrm{SiO}_{2}$, with slight variations between samples (figure 4.7G). Basin I groundmass glasses have notably higher $\mathrm{Na}_{2} \mathrm{O}$ contents than their respective melt inclusions.

Both $\mathrm{MnO}$ and $\mathrm{Cr}_{2} \mathrm{O}_{3}$ show high degrees of scatter (figure 4.7F \& I), likely associated with low contents and high analytical uncertainties. Broadly, MnO compositions stay moderately consistent between melt inclusions and groundmass compositions, with no distinct systematic variations. Despite significant scatter, backarc basin samples generally contain higher $\mathrm{Cr}_{2} \mathrm{O}_{3}$ than the arc front samples. Conversely, $\mathrm{MnO}$ contents are generally higher within arc front samples than the backarc samples.

Analysed melt inclusions and groundmass glasses are consistent with whole rock compositions of previously published proximal back-arc basins and arc front samples (figure 4.7; Gamble et al., 1993c; Wright and Gamble, 1999; Haase et al., 2006; Pullan, 2018). Basin I and D samples share strong similarities with Havre Trough basin whole rock compositions. Rumble III and Rumble II West samples are broadly consistent with SKA volcanoes (figure 4.7). These similarities are suggestive of generally consistent compositional trends between arc front and back-arc magmas. 


\subsubsection{Volatiles}

Sulfur versus $\mathrm{SiO}_{2}$ follows a strong negative curvilinear trend with consistent decreases in sulfur abundance from melt inclusions to associated ground mass glasses (figure 4.7J). Aside from two anomalously high RIIW-1 samples, all arc front melt inclusions have sulfur contents below $\sim 0.06 \mathrm{wt} . \%$, with most arc front samples ranging from $\sim 0.05-0.003$ wt.\% sulfur. Back-arc basin melt inclusions are typically above 0.05 wt.\% sulfur. Groundmass glasses of all samples lie below 0.02 wt.\% sulfur, the highest being from Basin D.

All samples display increasing $\mathrm{Cl}$ content with increasing $\mathrm{SiO}_{2}$ (figure $4.7 \mathrm{~K}$ ). The different sample locations, follow notably distinct trends however. Basin I glasses have the highest $\mathrm{Cl}$ contents at a given $\mathrm{MgO}$ or $\mathrm{SiO}_{2}$ value, and follow a distinctly separate trend from all other samples. RIIW-1 and 2 show similar $\mathrm{Cl}$ compositions, and have the lowest $\mathrm{Cl}$ abundances relative to $\mathrm{SiO}_{2}$. However, these two are distinct from RIIW-3 samples which have higher $\mathrm{Cl}$ contents and shares more similarities to the Rumble III samples. Basin D glasses distinct from Basin I, following a moderate trend similar to that of RIIW-3, although at higher $\mathrm{MgO}$ and lower $\mathrm{SiO}_{2}$ (figure 4.7K).

$\mathrm{H}_{2} \mathrm{O}$ contents of the melt inclusions are highly variable, both within and between sample locations, with samples displaying large variations of $\mathrm{H}_{2} \mathrm{O}$ at similar $\mathrm{SiO}_{2}$ contents (figure 4.7L). Rumble III samples show the least variance, ranging from $1.19-1.69$ and $0.53-1.08$ wt.\% $\mathrm{H}_{2} \mathrm{O}$ for RIII-1 and RIII-2, respectively. The highest and lowest measured $\mathrm{H}_{2} \mathrm{O}$ values are 3.1 and 0.35 wt.\% from RIIW-2 and RIIW-3 samples, respectively. Only two analysed glasses have measurable $\mathrm{CO}_{2}$ contents, $\mathrm{RIIW}-1$ inclusion D at 18 ppm, featuring 0.39 wt. $\% \mathrm{H}_{2} \mathrm{O}$, and RIII-1 inclusion $\mathrm{AA}$ at $119 \mathrm{ppm} \mathrm{\textrm {CO } _ { 2 }}$ at 1.69 wt.\% $\mathrm{CO}_{2}$ (figure $4.7 \mathrm{~L}$ ).

\subsection{Trace element geochemistry}

Trace element data for the glasses are summarised in N-MORB normalised multi-element diagrams (figure 4.8) and chondrite normalised REE diagrams (figure 4.9). The samples typically show comparable composition patterns from individual locations with greater compositional variations apparent between sample locations. 
All samples display relatively high concentrations of fluid mobile, LILE (e.g., Rb, $\mathrm{Ba}, \mathrm{Pb}$ and $\mathrm{Sr}$ ) relative to average $\mathrm{N}-\mathrm{MORB}$ compositions (figure 4.8). For these elements, Rumble III and Basin I samples are most similar with the highest absolute concentrations whereas RIIW-1 and 2 samples have the lowest concentrations of LILE (figure 4.8A \& B). Basin D and RIIW-3 samples display similar, moderately high LILE contents (figure 4.8D \& C). High-field strength elements (e.g., Ta, Nb, Zr, Hf) show low concentrations and are depleted relative to NMORB (figure 4.8). Relative abundances of HFSE between locations are not consistent with the relative enrichment observed in the LILE. For example, $\mathrm{Nb}$ and Ta concentrations are lowest for Rumble III samples. Whereas, Basin I are only moderately depleted relative to N-MORB (figure 4.8E \& F). Basin D and RIIW-3 samples have comparable depletion of $\mathrm{Nb}$ and Ta that are close to N-MORB (figure 4.8 D \& C). Similar variations are not followed for $\mathrm{Zr}$ and $\mathrm{Hf}$, where all samples show slight to moderately lower concentrations than N-MORB, excluding the notably greater $\mathrm{Zr}$ and $\mathrm{Hf}$ depletion of Basin I samples (figure 4.8E). Rumble II West inclusion-K is compositionally distinct from all other samples with general lower abundances for most trace elements (figure 4.8). These patterns of relative enrichment of LILE and depletion of HFSE relatively to N-MORB are typical of subduction lavas (Gill, 1981). 

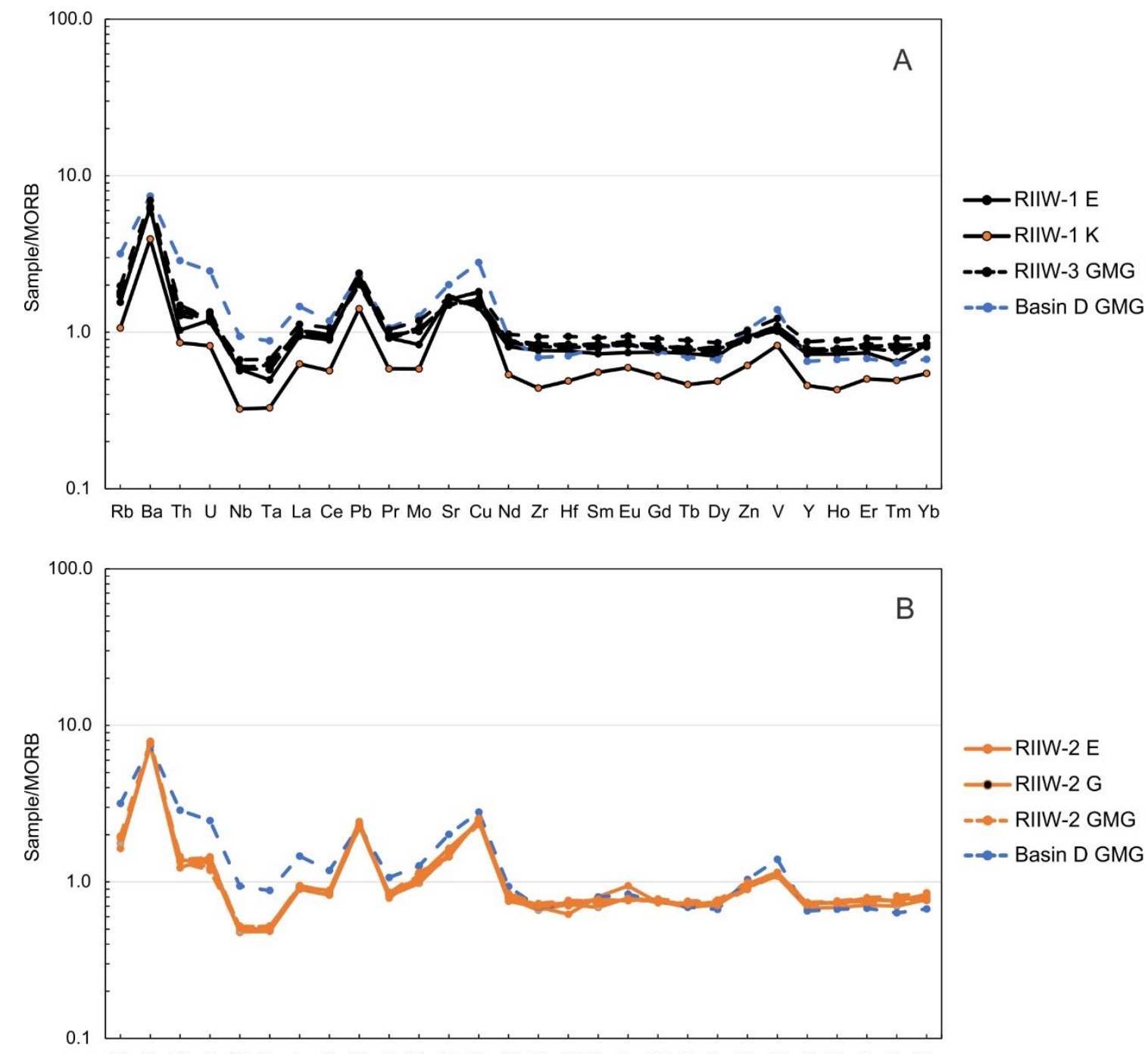

Rb Ba Th U Nb Ta La Ce Pb Pr Mo Sr Cu Nd Zr Hf SmEu Gd Tb Dy Zn V Y Ho Er Tm Yb

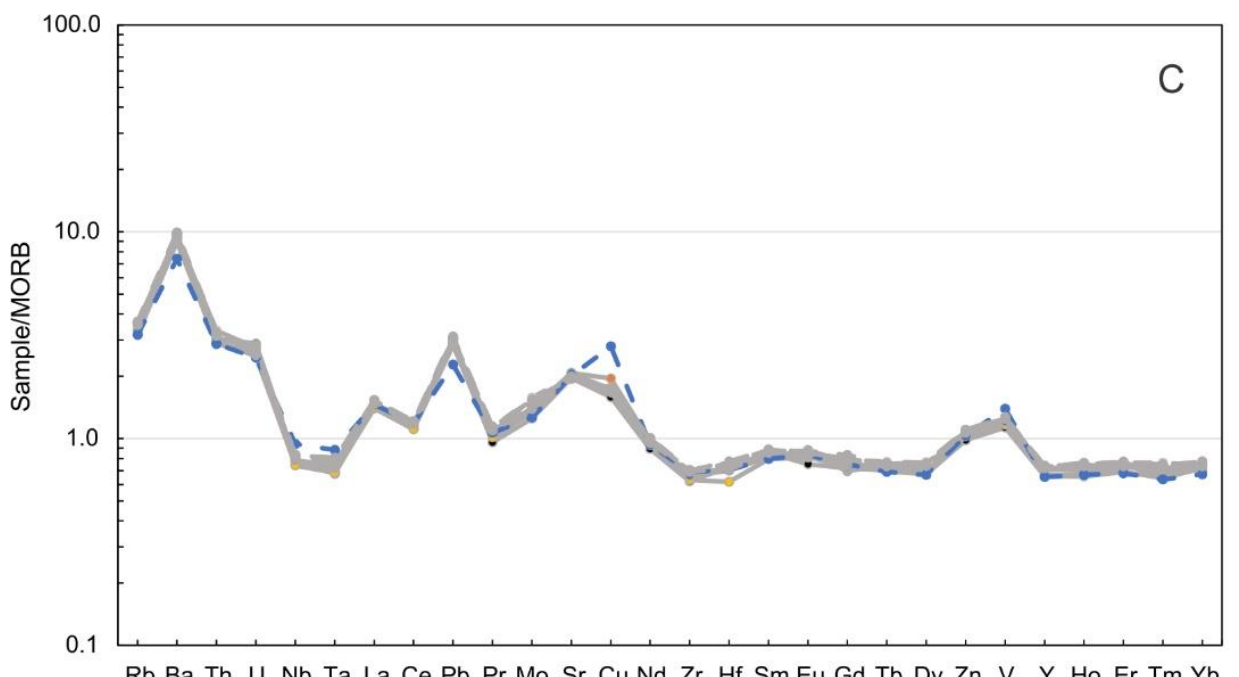

$\rightarrow$ RIIW-3 B

$\longrightarrow$ RIIW-3 EA

$\rightarrow$ RIIW-3 EB

$\longrightarrow$ RIIW-3 F

$\rightarrow$ RIIW-3 H

$-\infty-$ RIIW-3 GMG

$\rightarrow-$ Basin D GMG

Figure 4.8: N-MORB-normalized (after Gale et al., 2013) multitrace element diagram for SKAHT groundmass glass and melt inclusions investigated in this study. (A) RIIW-1, (B) RIIW-2, (C) RIIW-3, (D) Basin D, (E) Basin I, (F) RIII-1, (G) RIII-2. Melt inclusions are labelled as individual samples with unique symbols whereas groundmass glass compositions all share same symbol due to consistent compositions. Displayed on each is the average groundmass glass composition from Basin D as a reference. 

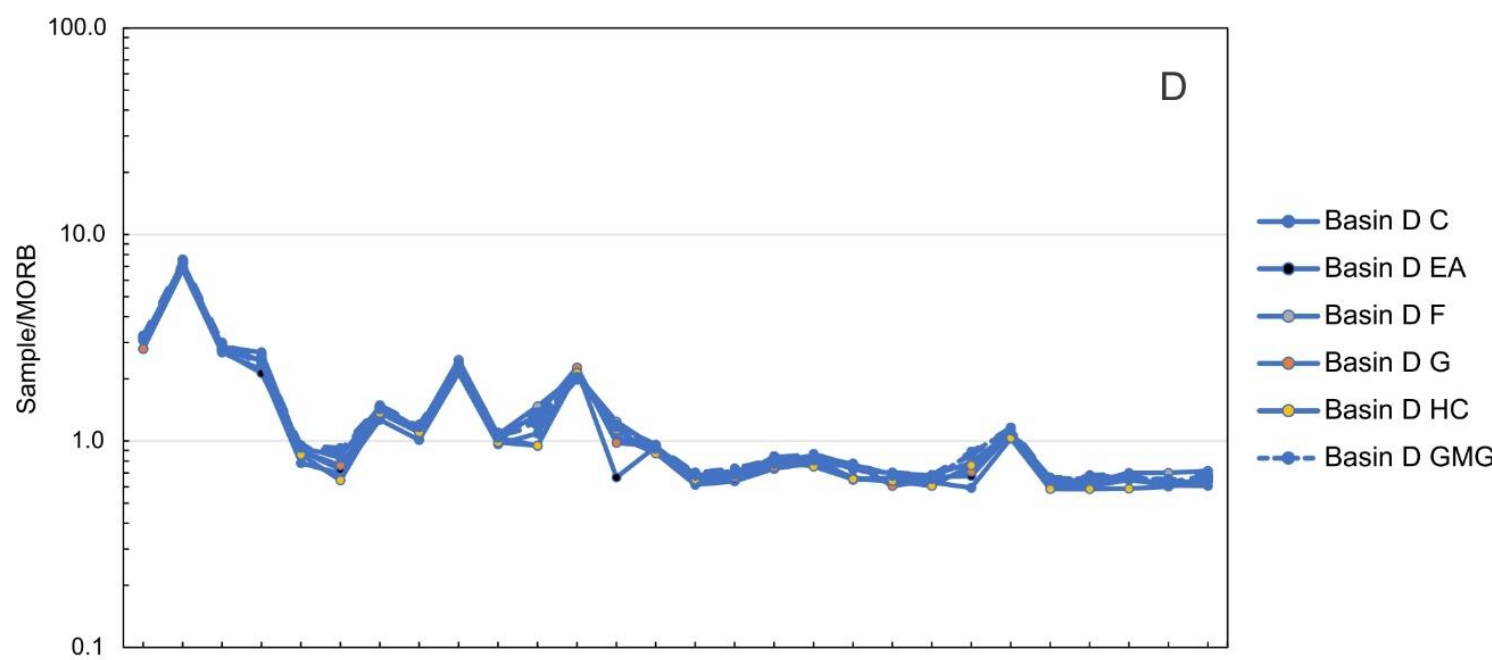

$\mathrm{Rb}$ Ba Th U Nb Ta La Ce Pb Pr Mo Sr Cu Nd Zr Hf Sm Eu Gd Tb Dy Zn V Y Ho Er Tm Yb

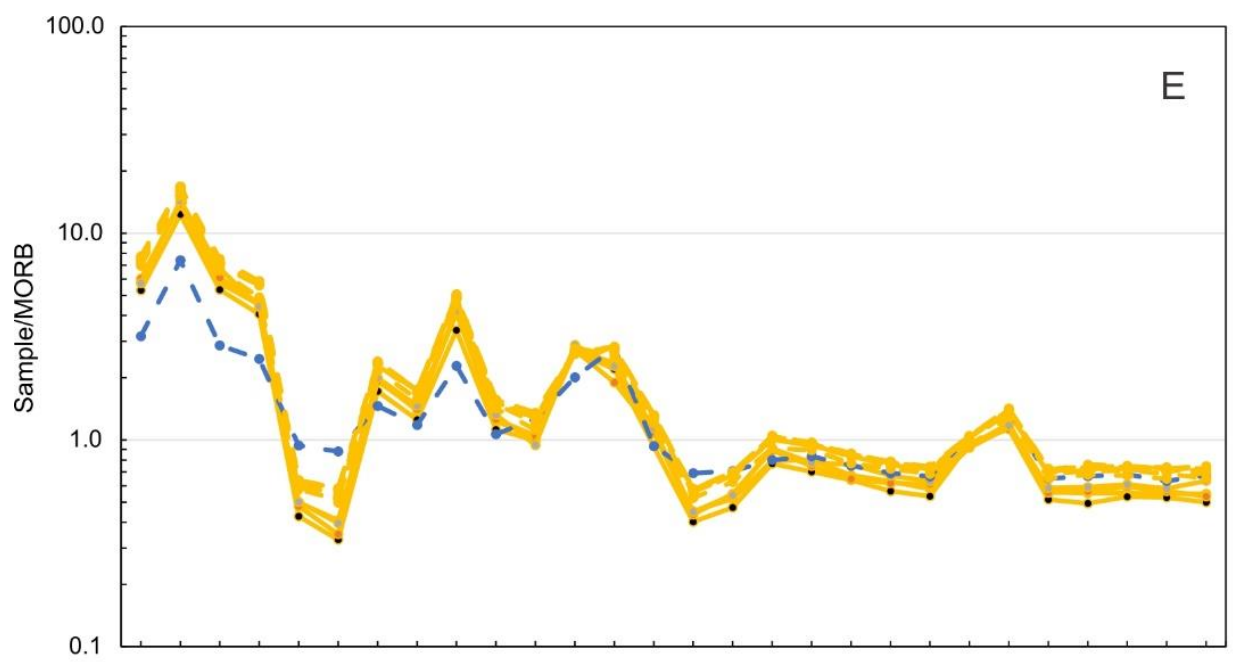

$\mathrm{Rb}$ Ba Th U Nb Ta La Ce Pb Pr Mo Sr Cu Nd Zr Hf Sm Eu Gd Tb Dy Zn V Y Ho Er Tm Yb

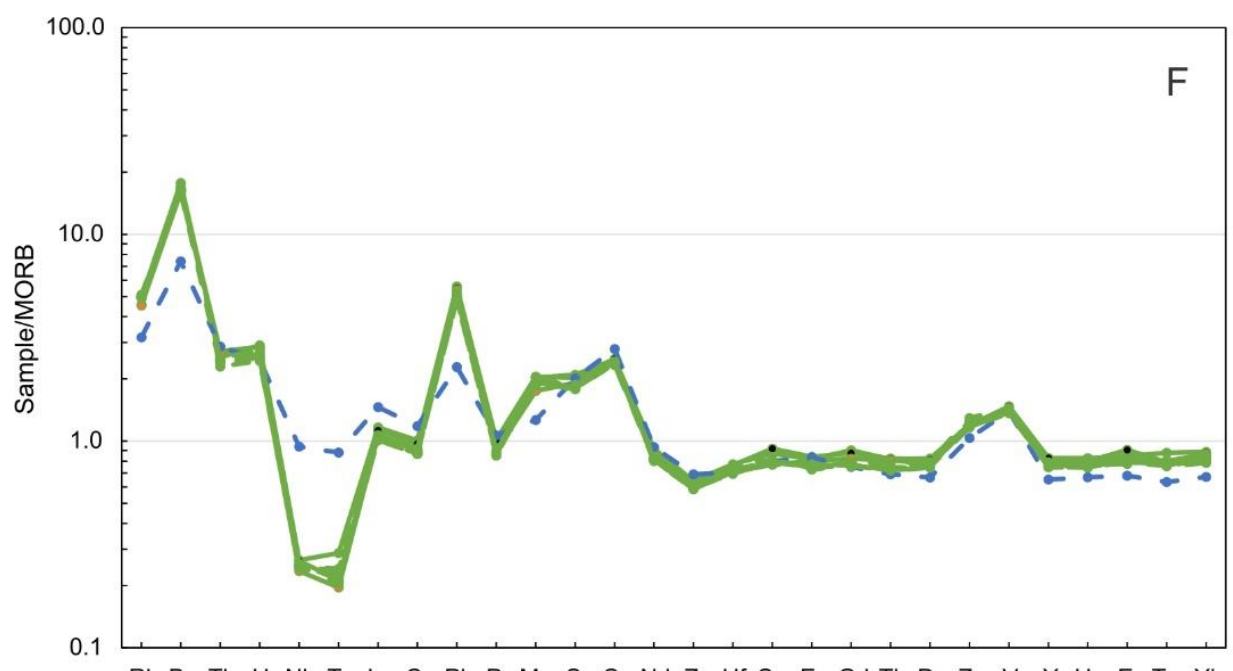

$\rightarrow$ RIII-1 AB

$\longrightarrow$ RIII-1 B

$\longrightarrow$ RIII-1 CB

$-\infty-$ RIII-1 GMG

$\rightarrow-$ Basin D GMG

Figure 4.8 Continued. 


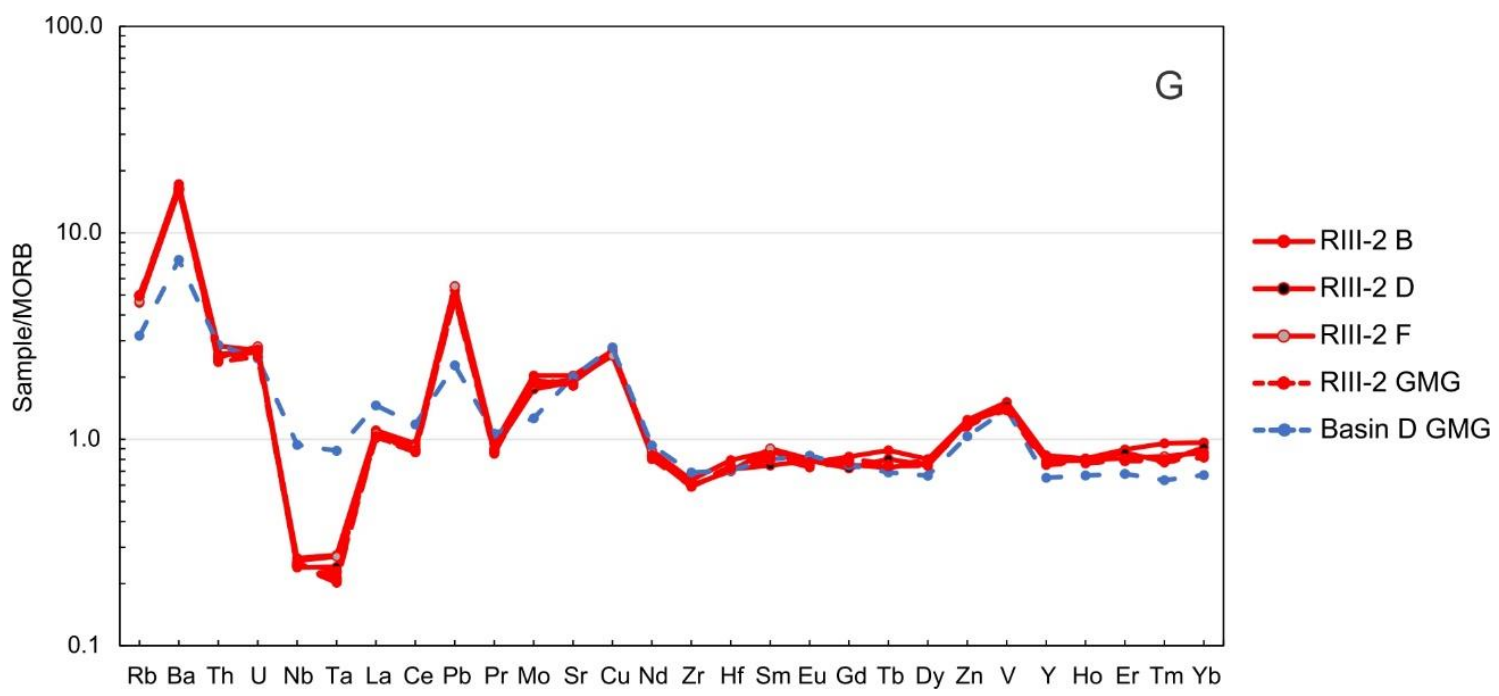

Figure 4.8 Continued.

Chondrite normalised, REE multi-element plots indicate a general systematic arc-perpendicular trend, whereby samples furthest from the arc front (Basins D and I) show a steeper LREE to HREE trend whereas arc front samples (RIIW-1 and 2 and RIII-1 and 2) show notably shallower-flat trends (figure 4.9). RIIW-3 samples are more similar to Basin D than to the other Rumble II West samples (figure $4.9 C \& D$ ), a relationship also observed for most trace elements (e.g., figure 4.8). Rumble III, RIIW-2, and two RIIW-1 samples (RIIW-1 inclusion E and average Groundmass) are similar to one another with an enrichment of approximately $16 x-19 x$ for all REE, relative to chondrite values (figure 4.9A, B, F \& G). RIIW-1 samples show the greatest variance, with one melt inclusion (RIIW-1 K) having the lowest chondrite-normalised REE pattern. Basin I shows the steepest REE pattern, with the greatest enrichment of LREE, followed by both Basin D and RIIW-3, which have very similar patterns. The back-arc basin and RIIW-3 samples also have the lowest HREE contents (excluding inclusion RIIW-1 K). 

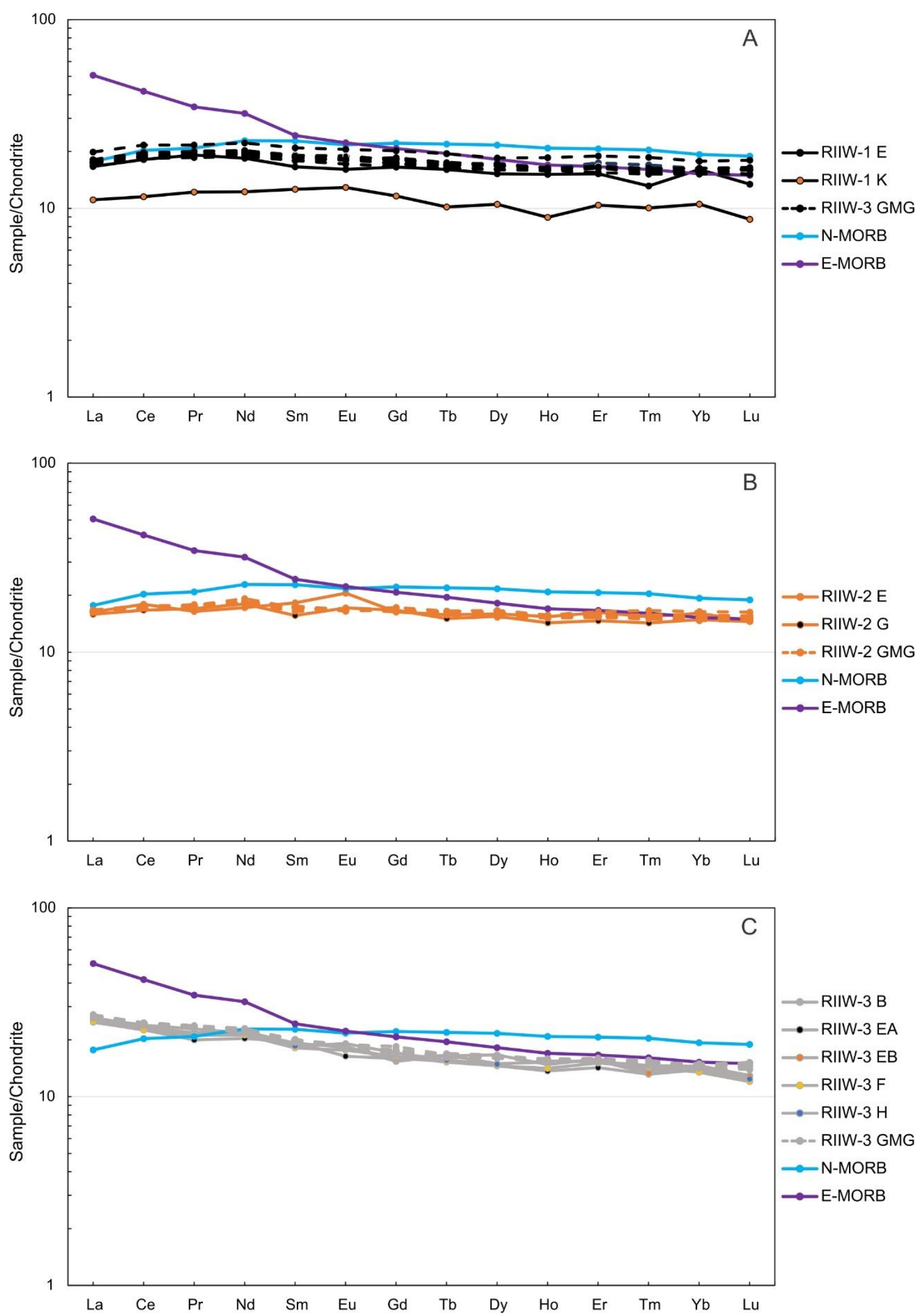

Figure 4.9: Chondrite normalised rare Earth element (REE) plots for Southern Kermadec Arc - Havre Trough melt inclusions and groundmass glasses. (A) RIIW-1, (B) RIIW-2, (C) RIIW-3, (D) Basin D, (E) Basin I, (F) RIIW-1, (G) RIIW-2. Blue line is N-MORB and red line is E-MORB (Gale et al., 2014). All normalization values are taken from Sun and McDonough (1989). 

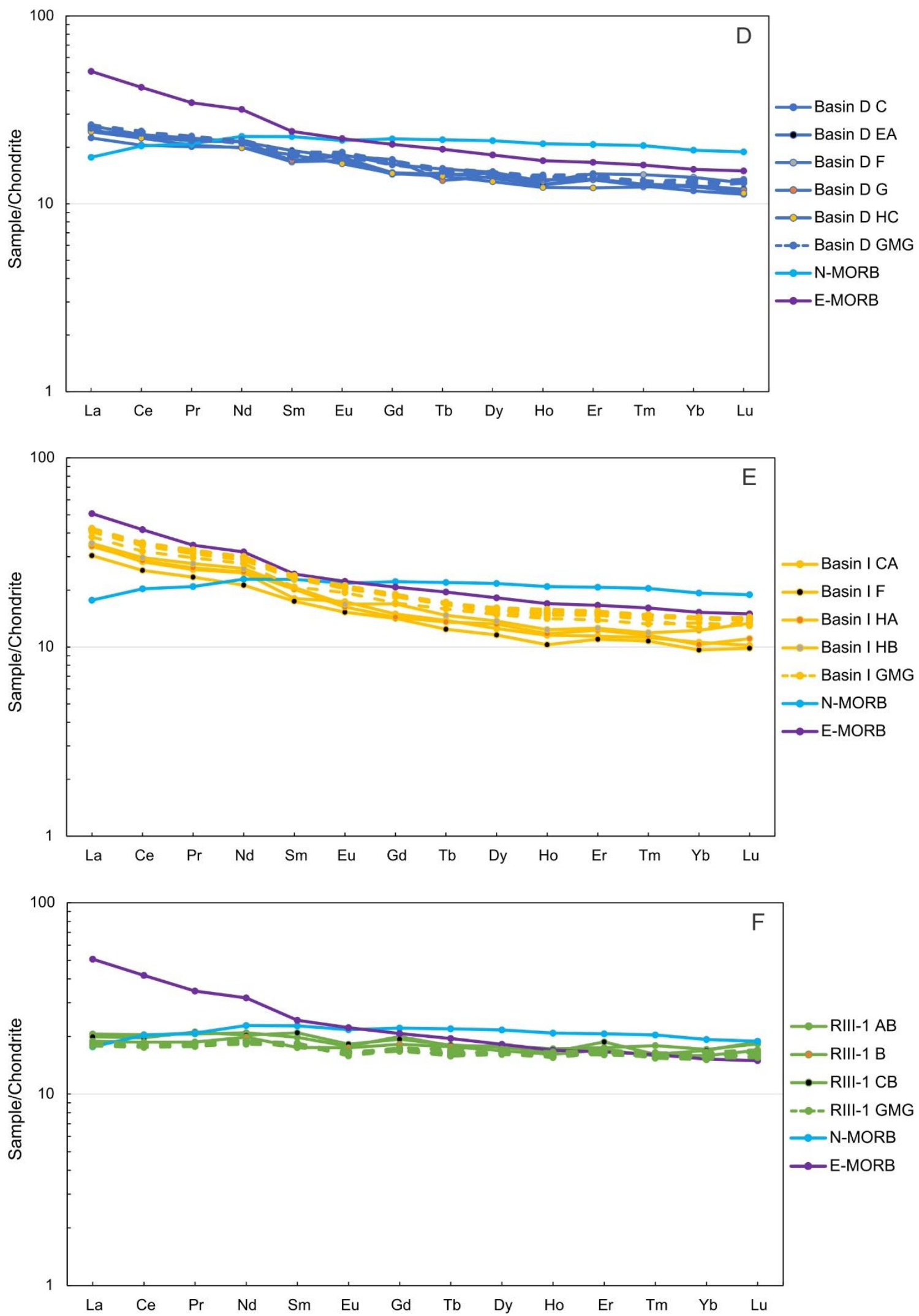

Figure 4.9 Continued. 


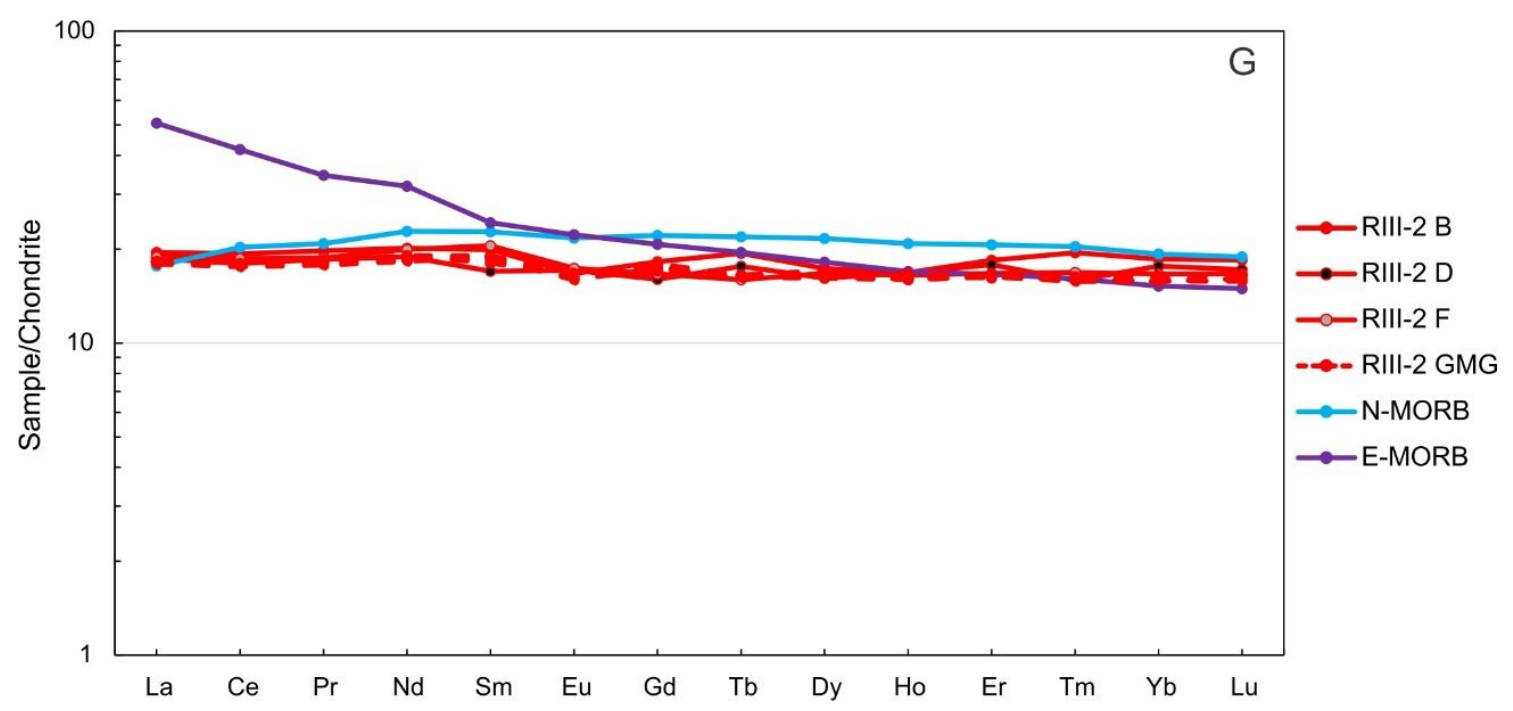

Figure 4.9 Continued.

\section{$\underline{4.5 .1}$ Trace metals}

Concentrations of selected trace metals are shown in figure 4.10. Rumble III and Basin I samples generally have higher $\mathrm{Cu}, \mathrm{V}, \mathrm{Mo}, \mathrm{Zn}$ and $\mathrm{Pb}$ contents than Basin D and Rumble II West (figure 4.10). All samples are enriched in $\mathrm{Cu}, \mathrm{V}$, and $\mathrm{Pb}$ relative to average N-MORB (figure 4.10A, B, \& C). In this dataset, Rumble III samples consistently exhibit the highest concentrations of metals, whereas Basin D is generally the least enriched at comparable $\mathrm{SiO}_{2}$, with one inclusion having lower $\mathrm{Cu}$ concentrations than average N-MORB. Excluding Rumble III and the groundmass glasses of Basin I and RIIW-3, all other samples are depleted in Zn relative to average N-MORB. Rumble III glasses have $\mathrm{Zn}$ contents that are approximately $15 \%$ greater than N-MORB values. Molybdenum concentrations of Basin I are most similar to that of N-MORB. RIIW-1 and 2 samples have similar Mo concentrations to $\mathrm{N}-\mathrm{MORB}$ but at higher $\mathrm{SiO}_{2}$ values; the one RIIW-1 melt inclusion with comparable $\mathrm{SiO}_{2}$ contents to N-MORB (and basin I) has notably lower Mo concentration (figure 4.10E). Generally, groundmass glass metal abundances are comparable or greater than those of their respective olivine-hosted melt inclusions however, Rumble III groundmass glass $\mathrm{Cu}, \mathrm{V}$, and $\mathrm{Pb}$ contents are lower than their respective most silicic melt inclusions (figure 4.10). 

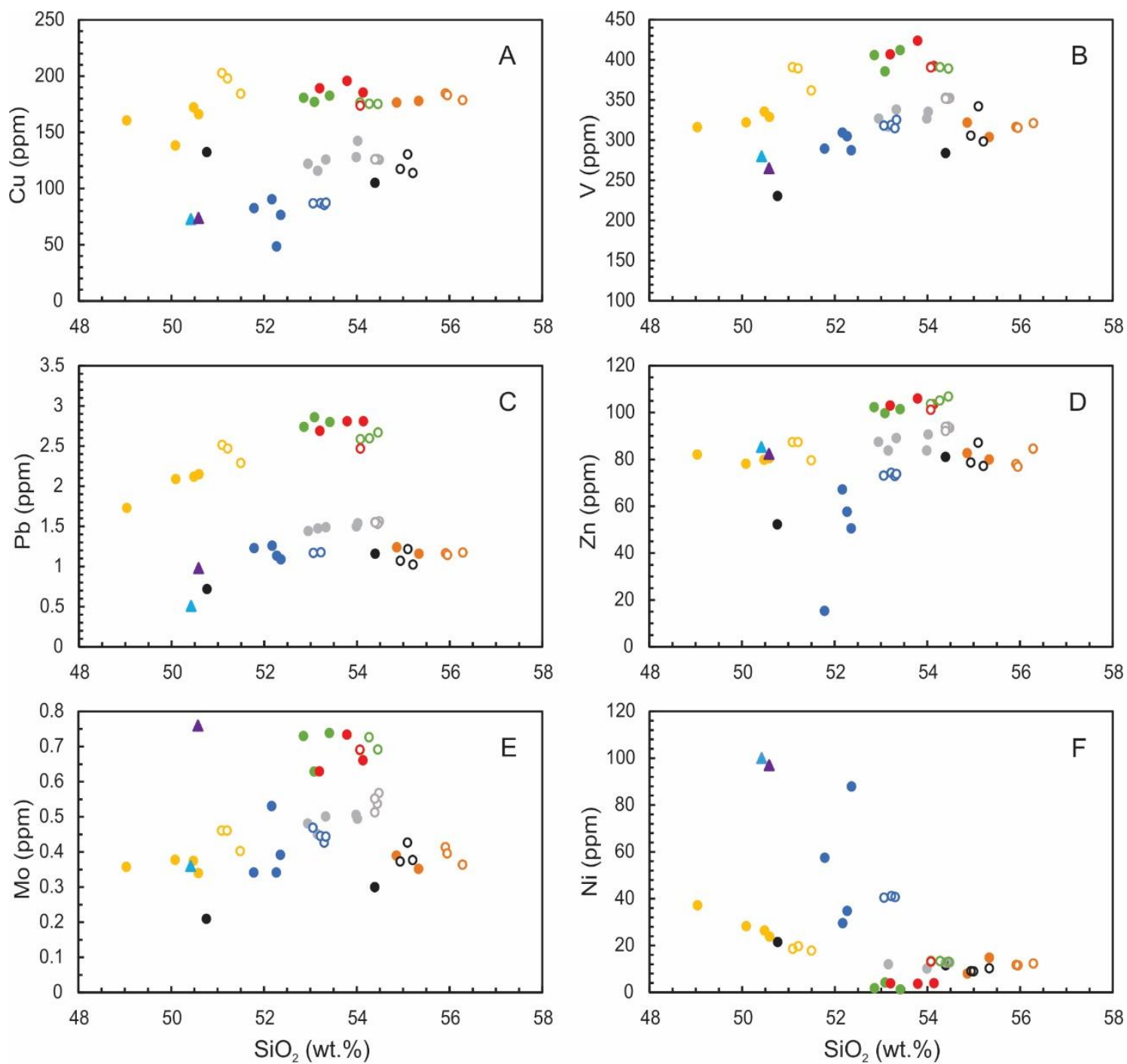

Figure 4.10: Bivariate element plots of select trace metals versus $\mathrm{SiO}_{2}$ (wt.\%). (A) $\mathrm{Cu},(\mathrm{B}) \mathrm{V}$, (C) Pb, (D) $\mathrm{Zn},(\mathrm{E}) \mathrm{Mo}$, and (F) Ni to indicate metal behaviour during fractional crystallization. Also included as reference are average $\mathrm{N}$ MORB and E-MORB compositions, sourced from Gale et al., (2013).

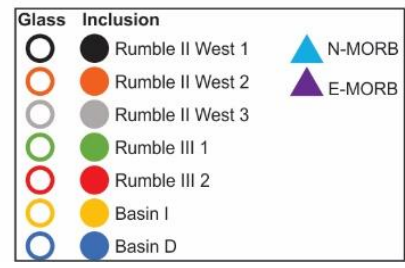


Chapter 5: Discussion 


\subsection{Magmatic Processes}

\section{$\underline{\text { 5.1.1 Magmatic Fractionation }}$}

All samples have phenocryst assemblages of plagioclase + olivine + clinopyroxene, as well as plagioclase microlites present within the groundmass. If the phenocrysts formed via fractional crystallization of the host melt, this should be apparent in the liquid evolution recorded by the major element concentrations in the analysed melt inclusions and groundmass glasses.

Melt inclusions sample relatively small regions within a magmatic system that are likely to be heterogeneous at the sampled scale. Therefore, inclusions may have considerable compositional variance. Conversely, groundmass glasses, the final melt phase quenched on eruption, are likely to represent a more homogenized sample (Maclennan, 2008; Laubier et al., 2012; Bo et al., 2018; Neave et al., 2018). This may introduce scatter to liquid lines of descent recorded by melt inclusions and groundmass glass. Nonetheless, some general and consistent trends can be observed in the samples.

The observed decrease in $\mathrm{MgO}$ with increasing $\mathrm{SiO}_{2}$ (figure 4.7A) shown by all samples is consistent with the fractionation of $\mathrm{Mg}$-bearing silicates such as olivine \pm clinopyroxene. The different sample localities however, show distinct trends. Basin $D$, and to a lesser extent RIIW, are offset systematically to higher $\mathrm{MgO}$ for a given $\mathrm{SiO}_{2}$ content than Basin I and Rumble III (figure 4.7A). These differences likely reflect either compositional differences in their respective primary magmas or differences in their magmatic evolution, or a combination of both.

The fraction of olivine \pm pyroxenes dominating the magmatic evolution of the sampled melts is further supported by compositional trends in other major and minor element abundances.

Broad decreases in Ni with increasing $\mathrm{SiO}_{2}$ (and decreasing $\mathrm{MgO}$; figure 4.10F) are indicative of olivine fractionation. The back-arc basin samples show generally higher $\mathrm{Ni}$ than arc front samples, coupled with lower $\mathrm{SiO}_{2}$ (and higher $\mathrm{MgO}$ ). The decreasing Ni contents for Basins I and D samples indicate early onset and continuation of olivine fractionation, with the former showing lower $\mathrm{Ni}$ at a given $\mathrm{SiO}_{2}$, 
consistent with onset of olivine fractionation at lower $\mathrm{SiO}_{2}$ contents. The arc front samples have notably lower $\mathrm{Ni}$, with no obvious decreasing trends, indicative of melt inclusion entrapment following significant olivine fractionation has already occurred.

Overall, $\mathrm{Al}_{2} \mathrm{O}_{3}$ and $\mathrm{CaO}$ show general decreasing trends with increasing $\mathrm{SiO}_{2}$ (figure 4.7D \& E), consistent with the fractionation of clinopyroxene \pm plagioclase. In particular, within individual sample locations, $\mathrm{Al}_{2} \mathrm{O}_{3}$ decreases with increasing $\mathrm{SiO}_{2}$ and, with the exception of the two Rumble III samples, groundmass glasses have lower $\mathrm{A}_{2} \mathrm{O}_{3}$ contents than their respective melt inclusions (figure 4.7D), as expected from plagioclase fractionation.

The general increasing $\mathrm{TiO}_{2}$ trends with increasing $\mathrm{SiO}_{2}$ (decreasing $\mathrm{MgO}$; figure 4.7) suggests $\mathrm{TiO}_{2}$ is incompatible within fractionating phases. This indicates that the fractionation of a Ti bearing mineral phase such as spinel or magnetite was not significant in the evolution of the sampled magmas.

Opaque oxides were observed only as inclusions within back-arc basin olivine crystals, and were not observed in the arc front samples (figure 4.1). The opaque inclusions are likely to be spinel group minerals and their presence within the back-arc samples suggest that olivine hosts grew in more primitive magmas. Their absence in volcanic front suites, coupled with lower $\mathrm{TiO}_{2}$ in the arc front samples relative to backarc samples, indicates that any spinel fractionation occurred early in the arc front magma evolution and stopped prior to crystallisation of the samples olivine crystals and associated melt inclusion entrapment.

The increasing $\mathrm{K}_{2} \mathrm{O}$ with $\mathrm{SiO}_{2}$ trends are consistent for each sample, reflecting evolution of individual magmas through crystal fractionation processes. The three of possibly four highly distinct trends cannot be explained by crystal fractionation alone and require different $\mathrm{K}_{2} \mathrm{O}$ contents in the primary mantle melts.

The Rumble III lavas are notably phenocryst-poor compared to the other lavas sampled ( $3-5$ vol.\% phenocrysts, compared to $20-40$ vol. $\%$ ), and are among the most evolved of the samples. These magmas may have stalled in the crust allowing for a larger degree of crystal settling compared to the other lavas, resulting in only a few, relatively late crystallising phenocrysts remaining suspended in the magma upon eruption. This is consistent with the very narrow range in melt inclusion and 
groundmass glass compositions for the two Rumble III samples (e.g., $\sim 1.3$ wt.\% range in $\mathrm{MgO}$, compared with 2 - 3 wt.\% for Basin I and Rumble II West-1 samples) and notable compositional overlap between inclusions and groundmass glasses. The Rumble III glasses therefore record a very limited range of magma evolution.

Rumble II West glasses, unlike Rumble III samples, span a wider range in magma evolution and show signficant inter-sample variation. Rumble II West-2 glasses have lower $\mathrm{TiO}_{2}, \mathrm{~K}_{2} \mathrm{O}, \mathrm{Na}_{2} \mathrm{O}$, higher $\mathrm{Al}_{2} \mathrm{O}_{3}$, and similar $\mathrm{FeO}_{\text {total, }} \mathrm{MgO}$, and $\mathrm{CaO}$ contents relative to RIIW-3. Rumble II West-1 has inclusion compositions that share similarities to both RIIW-2 and 3, most clearly shown in their $\mathrm{TiO}_{2}, \mathrm{Al}_{2} \mathrm{O}_{3}, \mathrm{Na}_{2} \mathrm{O}$, and $\mathrm{K}_{2} \mathrm{O}$ compositions. This is suggestive of compositionally distinct magmas at Rumble II West (e.g., RIIW-2 and RIIW-3), variably mixing (RIIW-1) and this has been captured in the melt inclusions.

Four samples have available whole rock data (Timm et al., 2012; Pullan, 2018), RIIW-1;2, Basin D and Basin I (figure 4.7). If the whole rock compositions represent a mix of melt and phenocrysts in a closed system, the whole rock compositions should also follow the liquid line of descent defined by the glasses analyses, which is what is broadly observed. The minor offsets in some major element abundances suggests the separation of fractionating phases \pm accumulation of antecrysts, modifying the bulk rock compositions. However, this appears to have been minimal.

In summary, the melt inclusions and groundmass glasses represent magmatic evolution of their respective magmas dominated by crystal fraction of olivine + clinopyroxene + plagioclase. In detail, $\mathrm{Ni}$ and $\mathrm{Cr}_{2} \mathrm{O}_{3}$ contents indicate significant olivine \pm clinopyroxene fractionation had occurred prior to entrapment of the melt inclusions, particularly for the volcanic front samples which generally represent more evolved melts. The different sample locations have tapped different primary melt compositions, most clearly exemplified by variable $\mathrm{K}_{2} \mathrm{O}$ contents, and including variable melt compositions sampled at a single locality (Rumble II West) and within a single magma (RIIW-1). 


\section{$\underline{5.1 .2 \text { Volatiles }}$}

Measured $\mathrm{H}_{2} \mathrm{O}$ abundances are highly variable (figure $4.7 \mathrm{~L}$ ) with only Basin I $\mathrm{H}_{2} \mathrm{O}$ contents consistent with fractionation-driven degassing. It is generally expected that the $\mathrm{H}_{2} \mathrm{O}$ contents of arc magmas will follow fractionation-driven degassing behaviour, based on other inclusion studies focussed on the SKAHT (e.g., Wysoczanski et al., 2006, 2012) and known $\mathrm{H}_{2} \mathrm{O}$ saturation-devolatilisation behaviour (Wallace, 2005; Wallace et al., 2015). All samples analysed for volatile contents contain measurable $\mathrm{H}_{2} \mathrm{O}$. However, only two contained detectable traces of $\mathrm{CO}_{2} ; \mathrm{RIIW}-1$ inclusion-D and RIII-1 inclusion-AA with 18 and 119 ppm CO CO $_{2}$ respectively (figure 5.1). This is significantly lower than expected from undegassed arc front lavas ( 2500 ppm; Wallace, 2005) indicating all samples have undergone a substantial amount of degassing and only RIIW-1 inclusion-D, and RIII-1 inclusion-AA may preserve undegassed magmatic $\mathrm{H}_{2} \mathrm{O}$ contents. Given the relative solubility of these volatiles (Holloway and Jakobsson, 1986; Newman and Lowenstern, 2002; Wallace et al., 2015), even the two samples with measurable $\mathrm{CO}_{2}$, likely represent significantly degassed melts, including the partial loss of $\mathrm{H}_{2} \mathrm{O}$. Therefore, all measured $\mathrm{H}_{2} \mathrm{O}$ compositions are minimum estimates.

The Rumble III inclusion with $119 \mathrm{ppm} \mathrm{CO}_{2}$ provides the best minimum $\mathrm{H}_{2} \mathrm{O}$ estimate for the Rumble III system, at 1.08 wt.\% $\mathrm{H}_{2} \mathrm{O}$. The highest measured $\mathrm{H}_{2} \mathrm{O}$ is from RIIW-3 (3.1 wt.\%; figure 5.1A), which is higher than that previously recorded for SKA lavas ( 2.6 wt.\% at Rumble II East; Wysoczanski et al., 2006, 2012). This suggests that the mantle beneath the arc front may have higher water contents than previously considered. Basins D and I have maximum $\mathrm{H}_{2} \mathrm{O}$ contents of 2.5 and 1.7 wt.\% $\mathrm{H}_{2} \mathrm{O}$, respectively (figure 5.10A), consistent with the back-arc mantle having a lower $\mathrm{H}_{2} \mathrm{O}$ content than the volcanic front mantle, however as all these samples have lost $\mathrm{CO}_{2}$, these values will also be minimum estimates. Fracturing and leakage of volatiles from melt inclusions, or post entrapment enrichment due to secondary olivine crystallisation may also produce variable $\mathrm{H}_{2} \mathrm{O}$ contents. However, no inclusions with evidence of fracturing, or more than minimal secondary olivine growth were selected for analysis to minimise these effects. Therefore, a range of $\mathrm{H}_{2} \mathrm{O}$ contents is believed to reflect true variations in volatile contents of the SKAHT. A similar line of argument was made by Luhr (2001), where higher $\mathrm{H}_{2} \mathrm{O}$ contents in melt inclusions most likely 
corresponds to greater entrapment depths, as $\mathrm{H}_{2} \mathrm{O}$ and other volatiles continually exsolve from the melt during ascent to preserve saturation limits. This is consistent with calculated saturation pressures of the glasses using VolatileCalc 2.0 (figure 5.1A; Newman and Lowenstern, 2002) which indicate that the olivine-hosted melt inclusions were trapped right through the magmatic process.
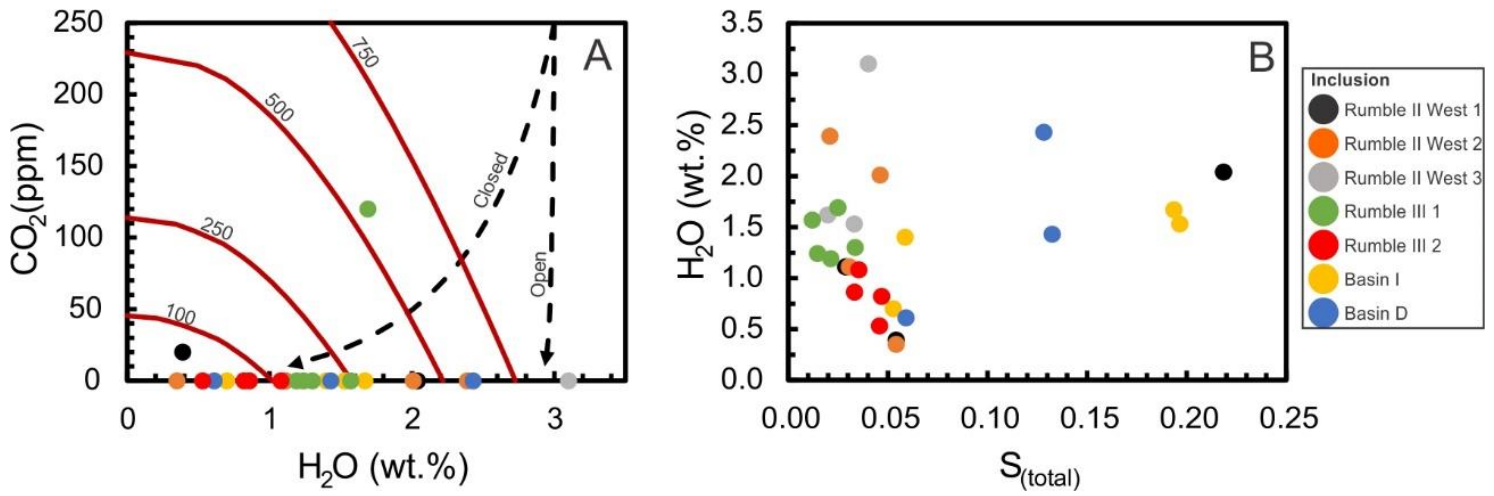

Figure 5.1: Volatile species in SKAHT olivine hosted melt inclusions of this study. (A) $\mathrm{CO}_{2}$ vs. $\mathrm{H}_{2} \mathrm{O}$. Also shown are degassing trends of $\mathrm{CO}_{2}$ and $\mathrm{H}_{2} \mathrm{O}$ during open and closed system behaviour (black dashed lines), and saturation pressures measured in bars (red lines) calculated using VolatileCalc 2.0 (Newman and Lowenstern, 2002). (B) $\mathrm{H}_{2} \mathrm{O}$ vs Sulfur total.

Total sulfur contents show a broad curvilinear decrease with increasing $\mathrm{SiO}_{2}$ consistent with sulfur loss during magmatic evolution. This is supported by lower sulfur contents in the groundmass glasses than their respective inclusions (figure 4.7J), suggesting that fractionation driven degassing plays a role (Wysoczanski et al., 2012). The back-arc samples typically have $>0.05 \mathrm{wt} . \%$ sulfur whereas the arc front samples have mainly $<0.05$ wt.\% sulfur. This general separation in sulfur contents is expected as back-arc lavas are generally less evolved and consequently less degassed. All groundmass glass samples have $<0.02$ wt.\% sulfur, which is likely due to extensive degassing immediately prior to and during eruption. The higher sulfur contents of back-arc basin groundmass glasses than arc front samples are consistent with eruption at greater water depths (higher hydrostatic pressures). Two inclusions from RIIW-1 have relatively high sulfur contents of 0.093 and 0.219 wt.\% at 50.9 and 51.7 wt.\% $\mathrm{SiO}_{2}$, respectively, aligning with the trends of the more primitive back-arc samples (figure 4.7L). This suggests that the majority of sulfur degassing occurs relatively 
rapidly over a range of $3-4 \mathrm{wt} . \% \mathrm{SiO}_{2}$ from approximately 48 to $50 \mathrm{wt} . \% \mathrm{SiO}_{2}$, following which the limited remaining sulfur degasses much more slowly.

Sulfur solubility in mafic magmas is complicated by variable responses to conditions depending on oxygen fugacity and the valence states of sulfur. Both $\mathrm{S}^{2-}$ and $\mathrm{S}^{6+}$ become more soluble with increasing temperature, thus a decrease in solubility and observed lower $\mathrm{S}$ concentrations with melt evolution may be partially attributed to melt cooling. The solubility of $\mathrm{S}^{2-}$ decreases with increasing pressure, with the opposite true for $\mathrm{S}^{6+}$. Furthermore, $\mathrm{S}^{2-}$ solubility appears to increase with greater $\mathrm{Fe}^{2+}$ proportions, suggesting a link to a dissolved FeS complex (Wallace et al., 2015; Wallace \& Edmonds, 2011). The transition of a $\mathrm{S}^{2-}$ to a $\mathrm{S}^{6+}$ dominated basaltic melt occurs between a melt oxygen fugacity of $0-1(\triangle Q F M)$. Unfortunately, there are no data available to evaluate the oxidation state of the lavas studies here, however, a prior study of lavas from Rumble II West, Rumble III and the Havre Trough, indicate $\mathrm{S}^{6+}$ proportions of approximately $25-40 \%$ at similar $\mathrm{MgO}$ values to arc front and back-arc samples analysed in this study (Wysoczanski et al., 2012). It seems likely that the samples studied here would have similar sulfur speciation. Furthermore, Wysoczanski et al. (2012) show that sulfide $\left(S^{2-}\right)$ proportions increase between melt inclusions and groundmass glasses, suggesting magmas become more reduced during sulfur degassing, implying that the removal of sulfur from SKAHT lavas is primarily as $\mathrm{S}^{6+}$ (Mathez, 1984; Burgisser and Scaillet, 2007).

The relationship between sulfur and $\mathrm{H}_{2} \mathrm{O}$ shows significant scatter (figure 5.1). The most distinct trend is shown by RIII-1 and 2 inclusions, which show sulfur contents increasing with decreasing $\mathrm{H}_{2} \mathrm{O}$. Conversely, Basins I and D show weak positive trends. The highly variable $\mathrm{H}_{2} \mathrm{O}$ contents of these melts combined with few arc front samples with lesser degrees of sulfur degassing makes it difficult to discern a systematic relationship. However as both volatiles are controlled by degassing associated with oversaturation driven by fractional crystallization and decreasing pressure, it is likely that back-arc samples are most representative of the general trend where both volatile species are lost during magma ascent.

Chlorine appears to be broadly incompatible during crystal fractionation, with generally increasing contents with increasing $\mathrm{SiO}_{2}$ (figure 4.7K). In detail, however, the largest $\mathrm{Cl}$ enrichment in the melts occurs relatively late stage with a significant 
increase in $\mathrm{Cl}$ abundance between the most evolved melt inclusions and their respective groundmass glasses, whereas $\mathrm{Cl}$ concentrations in the melt inclusions remain relatively constant (figure $4.7 \mathrm{~K}$ ). This is likely associated with $\mathrm{Cl}$ becoming more melt-soluble at lower pressure (Aiuppa et al., 2009). All samples are within the expected typical range of basaltic arc magmas $(500-2000 \mathrm{ppm})$ and have higher than that of MORB ( 40-60 ppm), consistent with input of $\mathrm{Cl}$ to the mantle wedge source via subduction-related slab devolatilisation (Schilling et al., 1978; Ito et al., 1983). The SKAHT samples are likely under-saturated in $\mathrm{Cl}$, based on maximum $\mathrm{Cl}$ values of both $\mathrm{H}_{2} \mathrm{O}$ saturated rhyolites and basalts at $0.3-3$ wt.\% $\mathrm{Cl}$, respectively. The relatively constant $\mathrm{Cl}$ contents amongst melt inclusions at varying $\mathrm{SiO}_{2}$ is suggestive of partial degassing of $\mathrm{Cl}$ during the majority of melt evolution, consistent with an affinity for degassing aqueous phases $\left(\mathrm{H}_{2} \mathrm{O}\right)$ that are less soluble at lower pressures (Aiuppa et al., 2009). Chlorine contents in the SKAHT lavas also behaves generally like $\mathrm{K}_{2} \mathrm{O}$, indicating that saline fluids did not enter the magma chamber (Kent et al., 2002).

\subsection{Magma source compositions}

\section{$\underline{\text { 5.2.1 Major elements and source variations }}$}

Significant variations in major element compositions are observed between sample locations, best exemplified by distinct magmatic trends for in $\mathrm{K}_{2} \mathrm{O}$ and $\mathrm{Cl}$ vs $\mathrm{SiO}_{2}$ (and $\mathrm{MgO}$; figure 4.7H \& $\mathrm{K} ; 5.2 \mathrm{~A}$ ). Offsets in $\mathrm{K}_{2} \mathrm{O}$ contents between different lavas at comparable $\mathrm{SiO}_{2}$ and $\mathrm{MgO}$ compositions are indicative of variable primary magma compositions resulting from variations in source composition and/or partial melting conditions.

Variable $\mathrm{K}_{2} \mathrm{O}$ contents in subduction zone settings have been linked to distances above the subducting slab (depth of the Wadati-Benioff Zone), with higher $\mathrm{K}_{2} \mathrm{O}$ contents correlating with deeper sourced magmas (Hatherton and Dickinson, 1969; Marsh and Carmichael, 1974). The differences in $\mathrm{K}_{2} \mathrm{O}$ contents of the SKAHT lavas sampled here is not consistent with this relationship however, as there is no correlation between $\mathrm{K}_{2} \mathrm{O}$ contents and distance from the arc trench; the two highest 
$\mathrm{K}_{2} \mathrm{O}$ lavas come from Basin I and Rumble III. Furthermore, there are variations in the $\mathrm{K}_{2} \mathrm{O}$ contents of melts samples from single locality, Rumble II West. Similarly, some of the most potassic lavas reported from the SKAHT come from a volcanic front volcano, Clark, that dominantly erupted more typical low-K lavas (Gamble et al., 1997).

$\mathrm{K}_{2} \mathrm{O}$ may be used as an indicator of source fertility as it behaves incompatibly during partial melting of the mantle, has higher concentrations in less depleted mantle (Sun and McDonough, 1989; Gale et al., 2013), and can also be affected by degree of partial melting with lower degree melts being more alkalic. However, $\mathrm{K}_{2} \mathrm{O}$ as well as $\mathrm{Cl}$, can also be added to the mantle via subduction component inputs (Kent and Elliott, 2002; Pearce and Stern, 2006).

Relatively high $\mathrm{Cl}$ and $\mathrm{K}_{2} \mathrm{O}$ contents of Rumble III samples appear to be related to subduction enrichment processes, based on the positive correlation of $\mathrm{K}_{2} \mathrm{O} / \mathrm{Nb}$ versus $\mathrm{Cl} / \mathrm{Nb}$ (figure 5.2B). Similar correlations have previously been interpreted as indicating increasing subduction enrichment in arc magmas (e.g., Kent and Elliott, 2002; Pearce and Stern, 2006). Niobium is a HFSE and considered immobile in slabderived melts and fluids. If $\mathrm{K}_{2} \mathrm{O}$ and $\mathrm{Cl}$ behave incompatibly, ratioing $\mathrm{K}_{2} \mathrm{O}$ and $\mathrm{Cl}$ to $\mathrm{Nb}$ negates the effects of fractional crystallisation and partial melting (Pearce and Stern, 2006). The high $\mathrm{K}_{2} \mathrm{O}$ and $\mathrm{Cl}$ contents in the Rumble III samples correlate with the highest $\mathrm{K}_{2} \mathrm{O} / \mathrm{Nb}$ and $\mathrm{Cl} / \mathrm{Nb}$ values, suggesting significant enrichment of these elements by subduction processes rather than reflecting partial melting of a relatively fertile source or low degrees of partial melting. By contrast, the comparably high $\mathrm{K}_{2} \mathrm{O}$ and $\mathrm{Cl}$ contents of Basin I glasses are coupled with lower $\mathrm{K}_{2} \mathrm{O} / \mathrm{Nb}$ and $\mathrm{Cl} / \mathrm{Nb}$, hence likely reflect melting of a more fertile mantle source with a lesser influence from subductionrelated enrichment (figure 5.2B). Basin D and RIIW-3 samples have similar $\mathrm{K}_{2} \mathrm{O}$ vs $\mathrm{SiO}_{2}$ trends, however, the $\mathrm{Cl}$ content of RIIW-3 glasses notably higher than that of Basin D glasses and more similar to that of the Rumble III samples (figure 4.7H). According to Kent \& Elliott (2002), a higher $\mathrm{Cl} / \mathrm{Nb}$ may also be indicative of greater crustal assimilation and fractional crystallization (AFC). Regardless, RIIW-3 appears to be sourced from a more enriched mantle compared to that of RIIW-1 and 2, although all three Rumble II West samples have consistent $\mathrm{K}_{2} \mathrm{O} / \mathrm{Cl}$ (figure $5.2 \mathrm{~B}$ ) suggesting a common enrichment mechanism. 

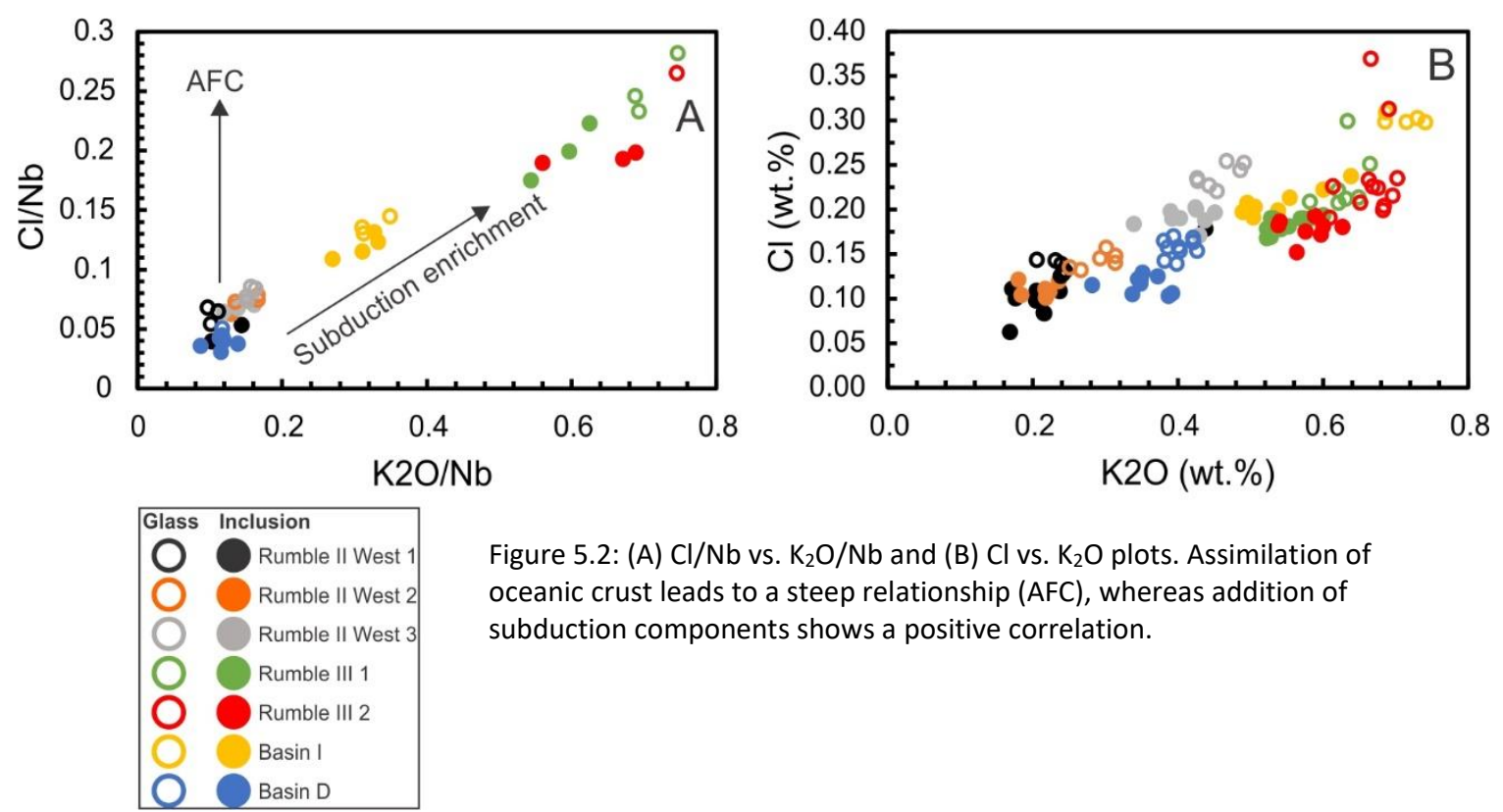

Figure 5.2: (A) $\mathrm{Cl} / \mathrm{Nb}$ vs. $\mathrm{K}_{2} \mathrm{O} / \mathrm{Nb}$ and $(\mathrm{B}) \mathrm{Cl}$ vs. $\mathrm{K}_{2} \mathrm{O}$ plots. Assimilation of oceanic crust leads to a steep relationship (AFC), whereas addition of subduction components shows a positive correlation.

Tracing major and minor element compositions along magmatic trends to a common $\mathrm{MgO}$ composition (e.g., 8 wt.\% $\mathrm{MgO}$ ) allows differences in source compositions to be evaluated. Following methods of Taylor and Martinez, (2003), $\mathrm{Fe}_{8}$, $\mathrm{Na}_{8}$, and $\mathrm{Ti}_{8}$ concentrations were calculated, representing approximate values of respective oxides at $8 \mathrm{wt} . \% \mathrm{MgO}$ (figure 5.3). Samples from individual locations form distinct clusters most clearly shown in $\mathrm{Ti}_{8} \mathrm{Vs} \mathrm{Fe}_{8}$, and $\mathrm{Na}_{8}$ vs $\mathrm{Fe}_{8}$ to a lesser extent (figure 5.3A \& B). For a given $\mathrm{Fe}_{8}$ value, Basin $\mathrm{D}$ has the highest $\mathrm{Na} 8$ and $\mathrm{Ti}_{8}$, and conversely the two Rumble III samples generally have the lowest $\mathrm{Na}_{8}$ and $\mathrm{Ti}_{8}$. Rumble II West-1 shows the greatest scatter with $\mathrm{Na}_{8}$ and $\mathrm{Ti}_{8}$ concentrations sharing similarities with both Basin D and RIIW-1 and 2 samples. Distinct trends are also apparent in $\mathrm{Na} / \mathrm{Ti}_{8}$ versus $\mathrm{Fe}_{8}$, with back-arc samples characterised by lower $\mathrm{Na} / \mathrm{Ti}_{8}$ (figure 5.3 ). The significant scatter in RIIW-1 glasses suggests that RIIW-1 inclusions potentially sampled distinct melt batches. As both $\mathrm{TiO}_{2}$ and $\mathrm{Na}_{2} \mathrm{O}$ are incompatible in mantle assemblages, similar to $\mathrm{K}_{2} \mathrm{O}$, these variations may reflect variable degrees of melting, with lower $\mathrm{Ti}_{8}$ and $\mathrm{Na}_{8}$ resulting from higher degrees of partial melting (Taylor and Martinez, 2003; Kelley et al., 2009). Alternatively, higher Ti and $\mathrm{Na}$ abundances may be the result of partial melting of a more fertile source. 

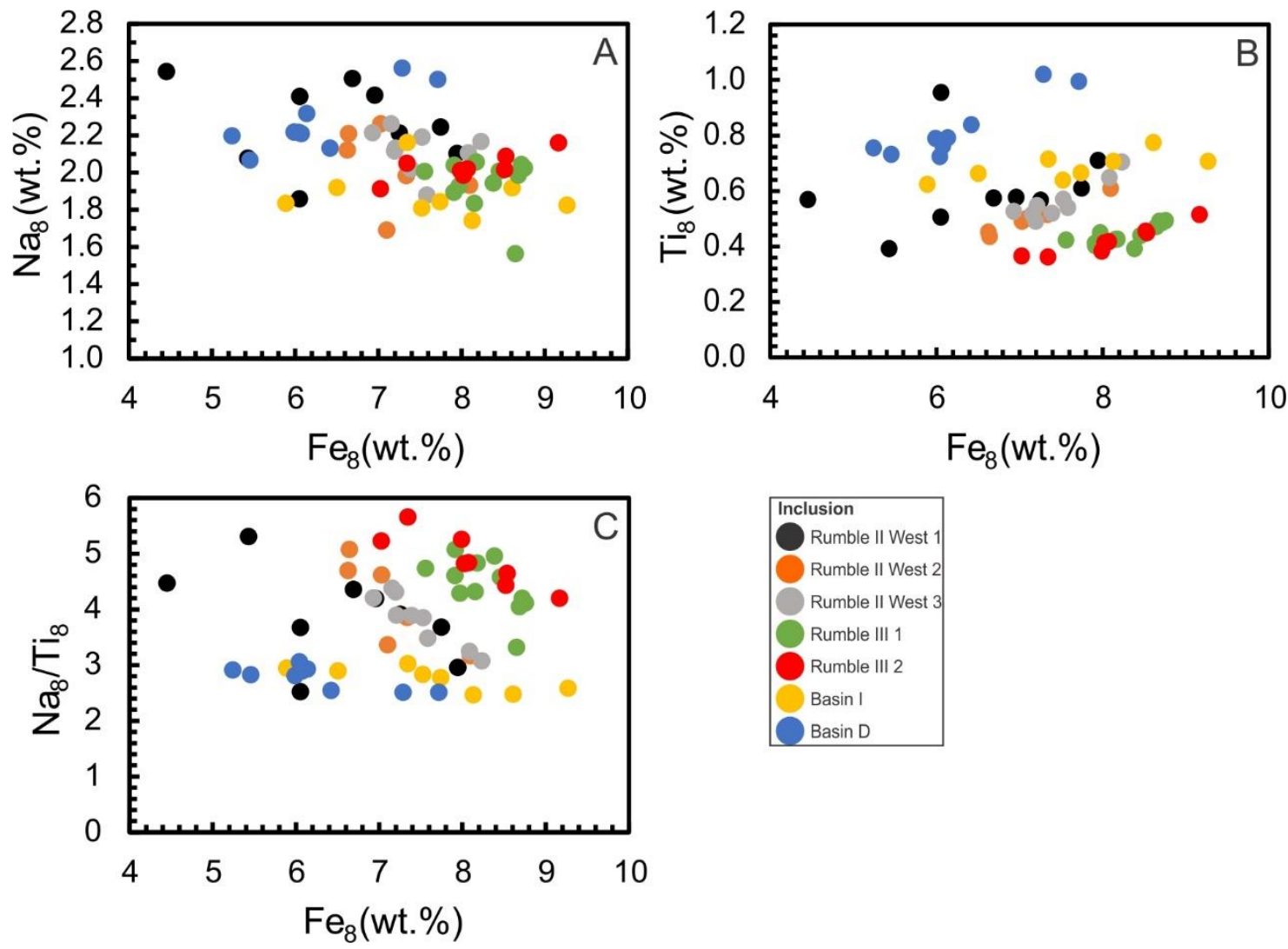

Figure 5.3: Select major element plots modelled to compositions at $8 \mathrm{wt} . \% \mathrm{MgO}$ following Taylor and Martinez (2003) to show variation in source composition (A) $\mathrm{Na}_{8} \mathrm{vs} \mathrm{Fe}_{8}$, (B) $\mathrm{Ti}_{8} \mathrm{vs} \mathrm{Fe}_{8}$, (C) $\mathrm{Na}_{8} / \mathrm{Ti}_{8} \mathrm{vs} \mathrm{Fe}_{8}$. Only melt inclusions are show as groundmass glasses likely experienced too high crystal fractionation for accurate modelling.

\subsubsection{Mantle Fertility}

The fertility of a mantle source is linked to prior partial melting events, with a more depleted mantle resulting from extraction of larger partial melt fractions. Mantle source fertility for arc magmas can be investigated though the use of incompatible trace element ratios such as $\mathrm{Nb} / \mathrm{Yb}$ (figure $5.4 \mathrm{~A}$ ), which compare a highly incompatible to a less incompatible trace element, both of which are relatively immobile in slabderived fluids and melts (Pearce and Stern, 2006). In typical arc settings, the mantle wedge back-arc magma source is generally less depleted than the mantle wedge beneath the arc front due to trench-ward circulation of the mantle. Niobium/ $\mathrm{Yb}$ in the glasses analysed here, suggest Basin D and RIIW-3 mantle sources are slightly enriched relative to an average $\mathrm{N}-\mathrm{MORB}$ composition $(\mathrm{Nb} / \mathrm{Yb}=1.45-1.28$ and $1.13-1.02$, 
respectively, $\mathrm{Nb} / \mathrm{Yb}$ of $\mathrm{N}-\mathrm{MORB}=1.1$; Gale et al., 2013), whereas arc front samples, Rumble III and RIIW-1 and 2, have significantly more depleted sources ( $\mathrm{Nb} / \mathrm{Yb}=0.27-$ $0.31,0.59-0.72$, and $0.57-0.67$, respectively). Basin I $(\mathrm{Nb} / \mathrm{Yb}=0.87-1)$ is similar to $\mathrm{N}$-MORB, despite being the furthest distance from the trench, although, back-arc basin sources are generally more fertile than arc front sources. Thus, although the back-arc basin melts appear derived from generally more fertile sources than the arc front melts, there is significant variation from this pattern, suggesting a considerably heterogeneous inflowing mantle wedge material. A similar conclusion has been noted by Todd et al. (2010), with Nb/Yb in cross-arc Rumble V Ridge basalts suggesting heterogeneous histories of melt extraction perpendicular to the trench.
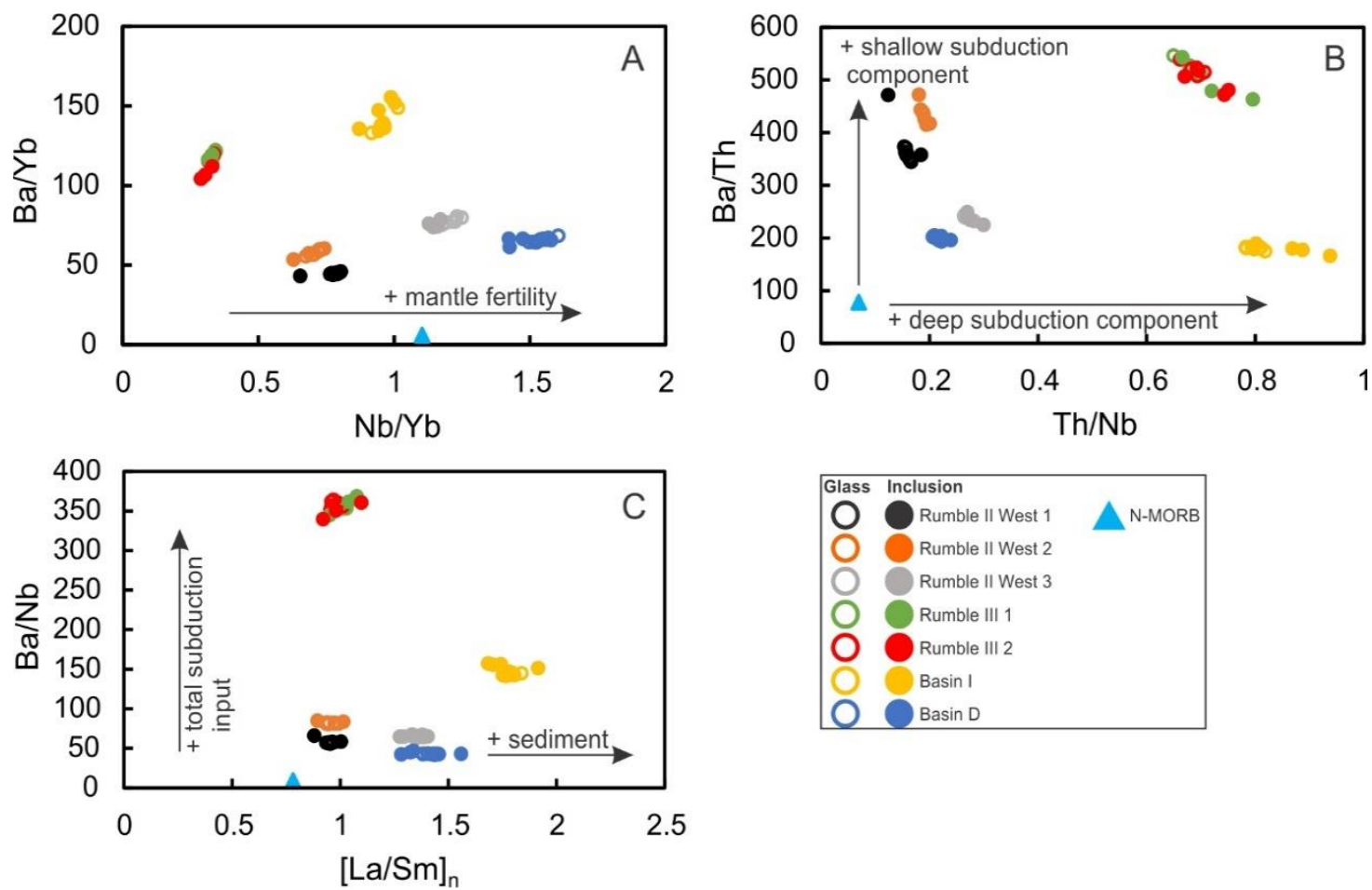

Figure 5.4. Element ratio plots showing $(\mathrm{A})$ mantle fertility $(\mathrm{Nb} / \mathrm{Yb}),(\mathrm{B})$ proportions of slab components $(\mathrm{Ba} / \mathrm{Th}=$ shallow aqueous component, $\mathrm{Th} / \mathrm{Nb}=$ deep component, $(\mathrm{C})$ total subduction component $(\mathrm{Ba} / \mathrm{Nb})$ and sediment melt $\left([\mathrm{La} / \mathrm{Sm}]_{\mathrm{n}}\right)$ of SKAHT samples investigated in this study. N-MORB values are representative of a melt composition with no subduction components (Gale et al., 2013). 


\subsubsection{Subduction Components}

Several incompatible trace element ratios can be utilised to evaluate subducting slab derived inputs into the overlying mantle wedge. These ratios can differentiate between components such as shallow aqueous fluid input and deeper slab melts or supercritical fluids (e.g., Pearce and Stern, 2006). Barium, Th, and Nb are commonly utilised in tracing these components for several reasons. Firstly, they have similar partition coefficients during both partial melting of the mantle and fractional crystallisation. Therefore, ratios involving these elements should be minimally affected by degree of partial melting or crystal fractionation. The latter is evident, for example, from no systematic changes in ratio values between melt inclusions and groundmass glass compositions for individual locations (figure 5.4). Secondly, chemical properties of these elements mean they are variably mobilised by different subduction zone components. Niobium, like other HFSE, is fluid-immobile and behaves conservatively in a subduction setting (Pearce and Stern, 2006). Its abundance represents a baseline, mantle wedge composition, prior to subduction modification. Barium, being a LILE, is highly mobile in aqueous fluids, and is transported by fluid released from the subducting slab. This is a relatively shallow process, although Ba can be added by deeper processes as well (Pearce and Stern, 2006). Thorium is immobile during aqueous fluid flow but is mobile in higher temperature phases (e.g., melts and supercritical fluids; Manning, 2006; Pearce and Stern, 2006; Ni et al., 2017) which predominantly occur deeper in the subduction system. Thus, $\mathrm{Ba} / \mathrm{Nb}$ can be used as a proxy of the total subduction component (figure 5.4C), Ba/Th for the shallow, aqueous component, and $\mathrm{Th} / \mathrm{Nb}$ for deeper components (figure 5.4B).

Figure 5.4B showing $\mathrm{Ba} / \mathrm{Th}$ vs $\mathrm{Th} / \mathrm{Nb}$ reveals a general trend of decreasing $\mathrm{Ba} /$ Th values with distance from the arc front, with Rumble III samples displaying the largest shallow component and Basin I, the lowest. Interestingly, RIIW-3 is distinct from the other two Rumble II West samples with values more like back-arc samples. Overall the observed spatial trend in $\mathrm{Ba} / \mathrm{Th}$ is consistent with shallow aqueous fluid release from the subducting slab most strongly affecting the active volcanic front (e.g., Eiler, 2003; Wysoczanski et al., 2012; Bebout, 2014).

Deep subduction components, as represented by $\mathrm{Th} / \mathrm{Nb}$ (figure 5.4B), show less systematic variations with distance from the arc trench. Basin I glasses display the 
highest values $(\sim 0.8-0.93)$ with Rumble III glasses only slightly lower $(0.66-0.79)$. RIIW-1 and 2 samples contain the lowest Th/Nb ( 0.12 -0.2), whereas, RIIW-3 has a higher Th/Nb than Basin D (0.27 - 0.299 and $0.212-0.23$, respectively). Notably, Basin I and Rumble III glasses, with the highest $\mathrm{Th} / \mathrm{Nb}$ values represent the furthest and nearest from arc trench localities, respectively. However, both these locations are also offset southwards along strike of the arc from Rumble II West and Basin D, suggesting an along strike variation in the deep component may be more significant than trenchperpendicular variations.

A deep component can be further examined using $[\mathrm{La} / \mathrm{Sm}]_{\mathrm{n}}$ values (chondrite normalised $\mathrm{La} / \mathrm{Sm}$ ) to target input of slab derived melts, given that sediment melts will have elevated [La/Sm] values (Kent and Elliott, 2002). All samples show evidence for minor addition of sediment melt, with elevated $[\mathrm{La} / \mathrm{Sm}]_{\mathrm{n}}$ values relative to $\mathrm{N}-\mathrm{MORB}$ (figure $5.4 \mathrm{C}$ ). On the basis of $[\mathrm{La} / \mathrm{Sm}]_{\mathrm{n}}$, Basin I appears to have the greatest slab derived melt component, followed by Basin D and RIIW-3. However, the [La/Sm $]_{n}$ values may be higher in Basin D and RIIW-3 due to their more fertile sources.

With respect to both subduction components, and mantle fertility, RIIW-3, is compositionally more similar to that of the back-arc basin samples than to RIIW-1 and 2 samples, with deep subduction components ( $\mathrm{Th} / \mathrm{Nb})$ and mantle fertility ( $\mathrm{Nb} / \mathrm{Yb})$ intermediate between that of Basin I and Basin D. RIIW-3 also has distinctly higher $\mathrm{Cl}$ and $\mathrm{K}_{2} \mathrm{O}$ contents than the other two Rumble II West samples. The similar location of RIIW-1 and 2 samples and distinctly different composition to RIIW-3 samples suggests distinctly different mantle sources. RIIW-3 glasses may also represent a melt composition that has resulted from the mixing of partial melts sourced from mantle sources similar to RIIW-1;2 and nearby Basin D, which could explain the intermediate trace element composition of RIIW-3 glasses.

\subsubsection{Partial melting}

Differences in the degree of partial melting between melts can have significant effects on element concentrations, particularly elements that are incompatible within the mantle. In order to evaluate the effects of variations in partial melting, degrees of partial melting (f) were calculated for the analysed glasses using the methodology of 
Kelley et al. (2006), utilizing Ti as a proxy. Relatively low Mg (<7 wt.\%) glass compositions were included in this analysis due to the limited number of suitable samples, despite issues with relatively fractionated compositions. The use of potentially less suitable samples will likely increase scatter in the calculated degrees of partial melting. The partial melting values determined using this method will reflect total melt removal from a mantle source rather than just the partial melting that resulted in the production of the sampled magma. Nonetheless, this method gives insight into potential variability of partial melting of the mantle, and the effects on primary melt compositions.

In general, the calculated total melt fractions decrease from arc front to backarc with Basin I sample source from slightly higher partial melting than Basin D (figure 5.5). Basins D and I samples have calculated melt fractions (approximately $9-20 \%$ ) that are similar to those calculated for other back-arc samples including Ngatoroirangi Rift, and other basins of the Havre Trough, as well as the Lau Basin and Mariana Trough (e.g., Kelley et al., 2006; Wysoczanski et al., 2012). Higher degrees of partial melting $(15-50 \%)$ are calculated for the arc front volcanoes (Rumble II West and Rumble III). This is consistent with those calculated by Wysoczanski et al. (2012) for Rumble II West ( 30\%) and other SKA volcanoes (Rumble II East and Clark volcanoes) as well as the Kermadec Ridge ( 20-36\%).

The calculated degree of partial melting is affected by the depletion of the mantle source, in that a more depleted source has already experienced prior melt extraction event(s) and that calculation cannot distinguish between single or multiple melt extraction histories. This link is evident in the SKAHT glasses with a negative correlation between calculated degrees of partial melting and $\mathrm{Nb} / \mathrm{Yb}$ (mantle fertility proxy; figure 5.5D). It is unlikely that the calculated degrees of partial melting truly reflect the sampled melts, especially those of Rumble III with upwards of $50 \%$ partial melting calculated. Instead these values likely reflect a lower degree of melting from a mantle source that has experienced higher amounts of partial melting than other samples (e.g. Basin D and I). The high calculated degrees of partial melting and significant source depletion of Rumble III is consistent with it being one of the largest SKAHT volcanoes (Tontini et al., 2013). 
The calculated degrees of partial melting form a broad negative correlation with chondrite normalised $[\mathrm{La} / \mathrm{Lu}]_{\mathrm{n}}$ ratios. Lanthanum and $\mathrm{Lu}$ are moderately incompatible and less incompatible elements, respectively. Thus La/Lu decrease with greater degrees of partial melting. This relationship is observed in the sample suite, however Basin I inclusions feature the highest measured $[\mathrm{La} / \mathrm{Lu}]_{\mathrm{n}}$, and the second lowest calculated degree of melting. $[\mathrm{La} / \mathrm{Lu}]_{\mathrm{n}}$ as with $[\mathrm{La} / \mathrm{Sm}]_{\mathrm{n}}$ discussed previously, can also be affected by the addition of a deep subduction component. This may explain why Basin I, with the highest $[\mathrm{La} / \mathrm{Sm}]_{\mathrm{n}}$ and $\mathrm{Th} / \mathrm{Nb}$, has a higher $[\mathrm{La} / \mathrm{Lu}]_{\mathrm{n}}$ value than would be predicted from the relationship with degree of partial melting.
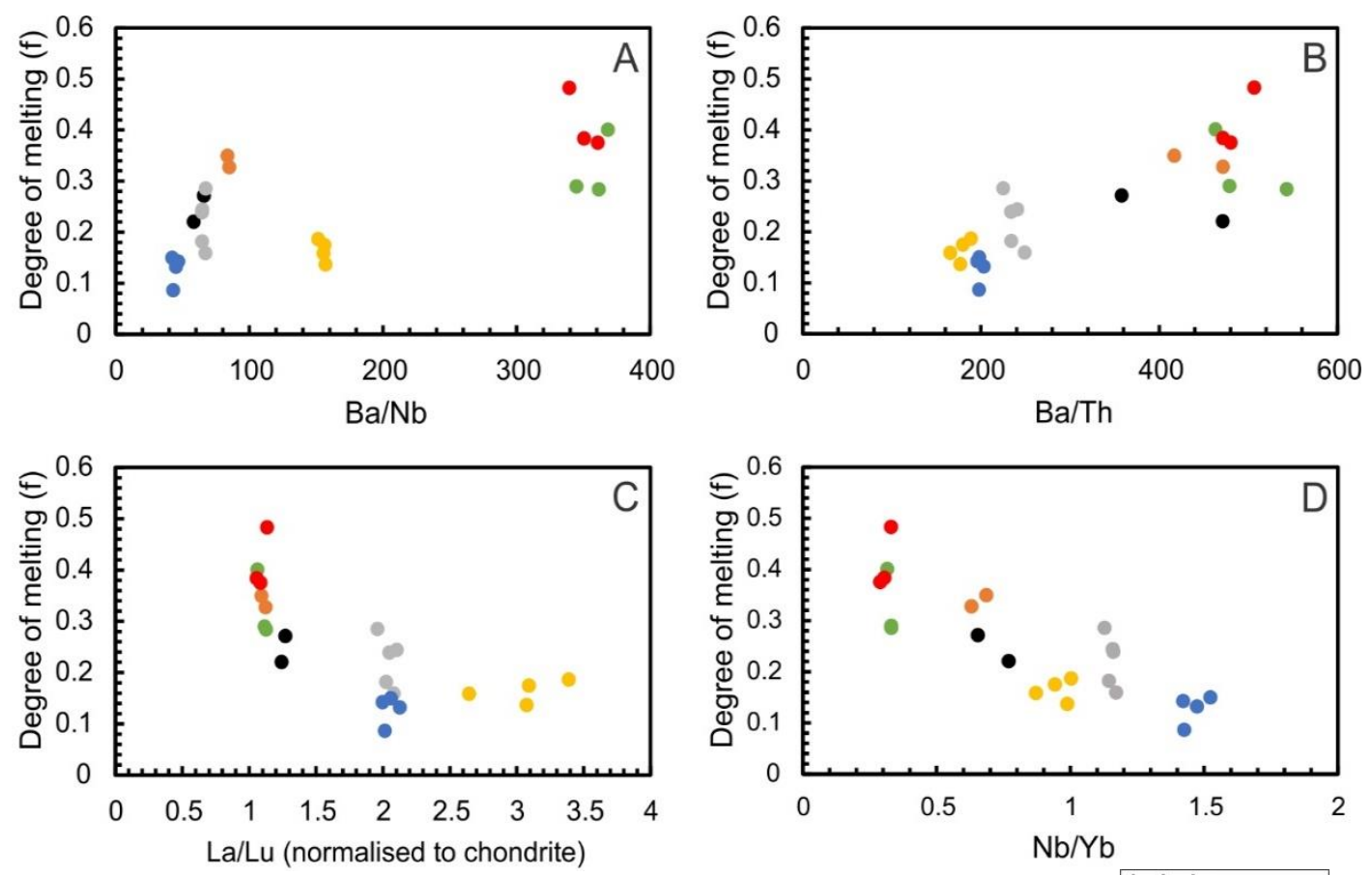

\begin{abstract}
Figure 5.5: Bivariate plots of calculated degree of melting (Kelley et al., 2006) against (A) Ba/Nb (total subduction input), (B) Ba/Th (shallow subduction input), (C) La/Lu (normalised to chondrite), and (D) $\mathrm{Nb} / \mathrm{Yb}$ (mantle fertility). Degrees of melting are only calculated for melt inclusion glasses as groundmass glasses likely experience too much fractionation.
\end{abstract}

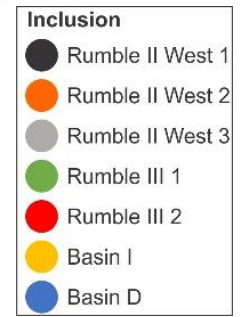

The calculated total degree of partial melting for the glasses show broad positive correlations with proxies of subduction inputs $(\mathrm{Ba} / \mathrm{Nb}$ and $\mathrm{Ba} / \mathrm{Th}$; figure $5.5 \mathrm{~A}$ \& B). The correlations with $\mathrm{Ba} / \mathrm{Nb}$, a proxy for total slab input into the mantle wedge (figure 5.5A) appear to follow two separate trends; Rumble II West samples, and Rumble III - Basin I, both anchored by Basin D samples. A stronger correlation with 
$\mathrm{Ba} / \mathrm{Th}$, a slab-derived aqueous fluid proxy, holds for all locations (figure 5.5B)

suggesting that aqueous fluid input may be a significant control on degree of melting.

This would be consistent with fluid-flux melting, whereby the mantle peridotite solidus in lowered by the addition of water (Schmidt and Poli, 2003; Tamura et al., 2007; Timm et al., 2016).

Alternatively, the total degree of melting may be linked to trench-ward cycling of the mantle with progressive tapping and subsequent depletion of the mantle source from back-arc to arc front. The measured distance of the sample locations from the Kermadec trench generally correlates with the degree of melting (figure 5.6), however with more scatter than the relationship between calculated degree of melting and $\mathrm{Ba} /$ Th (figure 5.5B). Basin I samples are also significantly offset at $\sim 296 \mathrm{~km}$ from trench, with slightly higher calculated degrees of melting than Basin D. As progressive mantle tapping with convection and aqueous fluid release from the subducting slab are both linked to distance from the trench (Eiler, 2003; Wysoczanski et al., 2012; Bebout, 2014) it is difficult to separate the relative effects of each on the total degree of partial melting. It is likely that the calculated degrees of partial melting represent the combined effects of continual source tapping and the particular degree of melting that resulted in the specific melt compositions of the analysed SKAHT glasses.

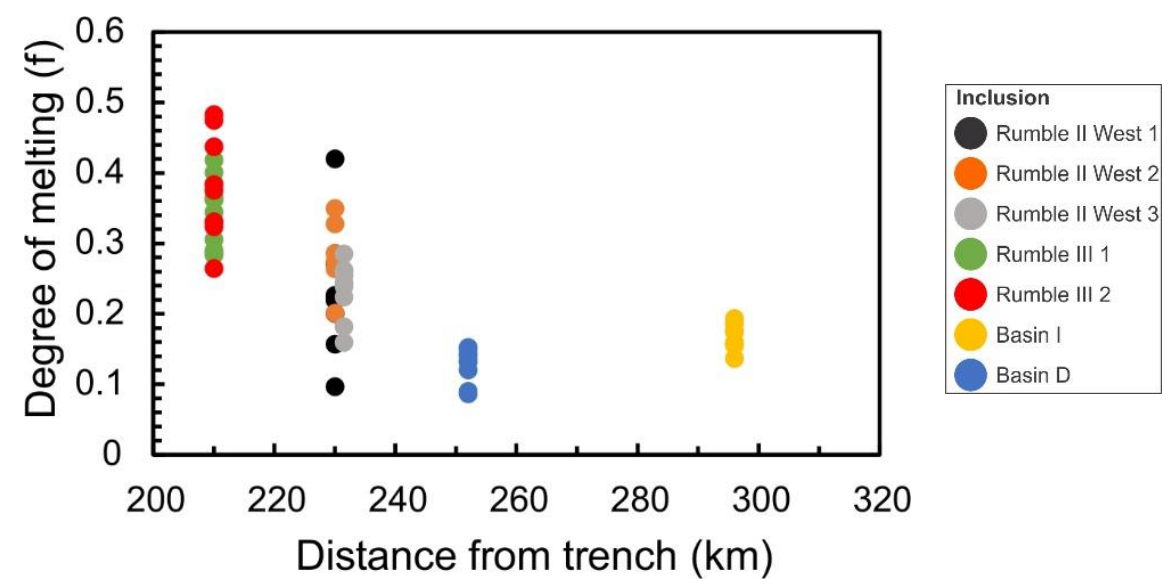

Figure 5.6: Calculated degrees of partial melting variations with measured distances of sample locations from the Kermadec Trench.

Collectively, between source variation, mantle fertility, and extent of partial melting proxies there are differences between samples from different locations. Basin D samples, with the highest $\mathrm{Ti}_{8}$ values $(1.02-0.72 \mathrm{wt} . \%)$, correspond to the most fertile mantle source as shown by $\mathrm{Nb} / \mathrm{Yb}$ ratios and lowest calculated degrees of partial 
melting ( $f=9-15 \%)$. Contrastingly, RIIW-3 glasses, with a slightly more fertile source than Basin I, have notably lower $\mathrm{Ti}_{8}$ concentrations, similar to RIIW-1 and 2 . This could be explained if the melt that produced the RIIW-3 glasses was the result of a higher degree of partial melting of a more fertile mantle than Basin I, thus leading to lower $\mathrm{Ti}_{8}$ and higher Nb/Yb within RIIW-3 samples compared to Basin I. This is consistent with a generally higher calculated total degree of partial melting for RIIW-3 glasses than for the Basin I glasses.

Proxies of mantle fertility such as $\mathrm{Nb} / \mathrm{Yb}$ are not fully consistent with an interpretation of $\mathrm{K}_{2} \mathrm{O}$ contents being an indicator of mantle fertility. For example, Basin I and Rumble III samples, with notably high $\mathrm{K}_{2} \mathrm{O}$ values $(\sim 0.4-0.8$ and $0.5-0.7$ wt.\%, respectively) have relatively low $\mathrm{Nb} / \mathrm{Yb}(\sim 0.87-1$ and $0.28-0.33)$, suggesting that $\mathrm{K}_{2} \mathrm{O}$ (and also $\mathrm{Cl}$ ), reflect a significant subduction input to the mantle sources of Basin I and Rumble III magmas (5.2B). This is further supported by the comparison of $\mathrm{Cl}$ and $\mathrm{K}_{2} \mathrm{O}$ contents to $\mathrm{Ba} / \mathrm{Th}$ and $\mathrm{Th} / \mathrm{Nb}$ (shallow and deep subduction components, respectively) indicating that $\mathrm{Cl}$ and $\mathrm{K}_{2} \mathrm{O}$ of arc front samples, excluding $\mathrm{RIIW}-3$, correlate strongly with an aqueous-fluid subduction component (figure 5.7). Chlorine and $\mathrm{K}_{2} \mathrm{O}$ contents of back-arc samples and RIIW-3 glasses show a stronger positive correlation with deep subduction components, especially Basin I, with significantly higher $\mathrm{Th} / \mathrm{Nb}$ and $\mathrm{Cl}(\mathrm{wt} . \%)$ values.
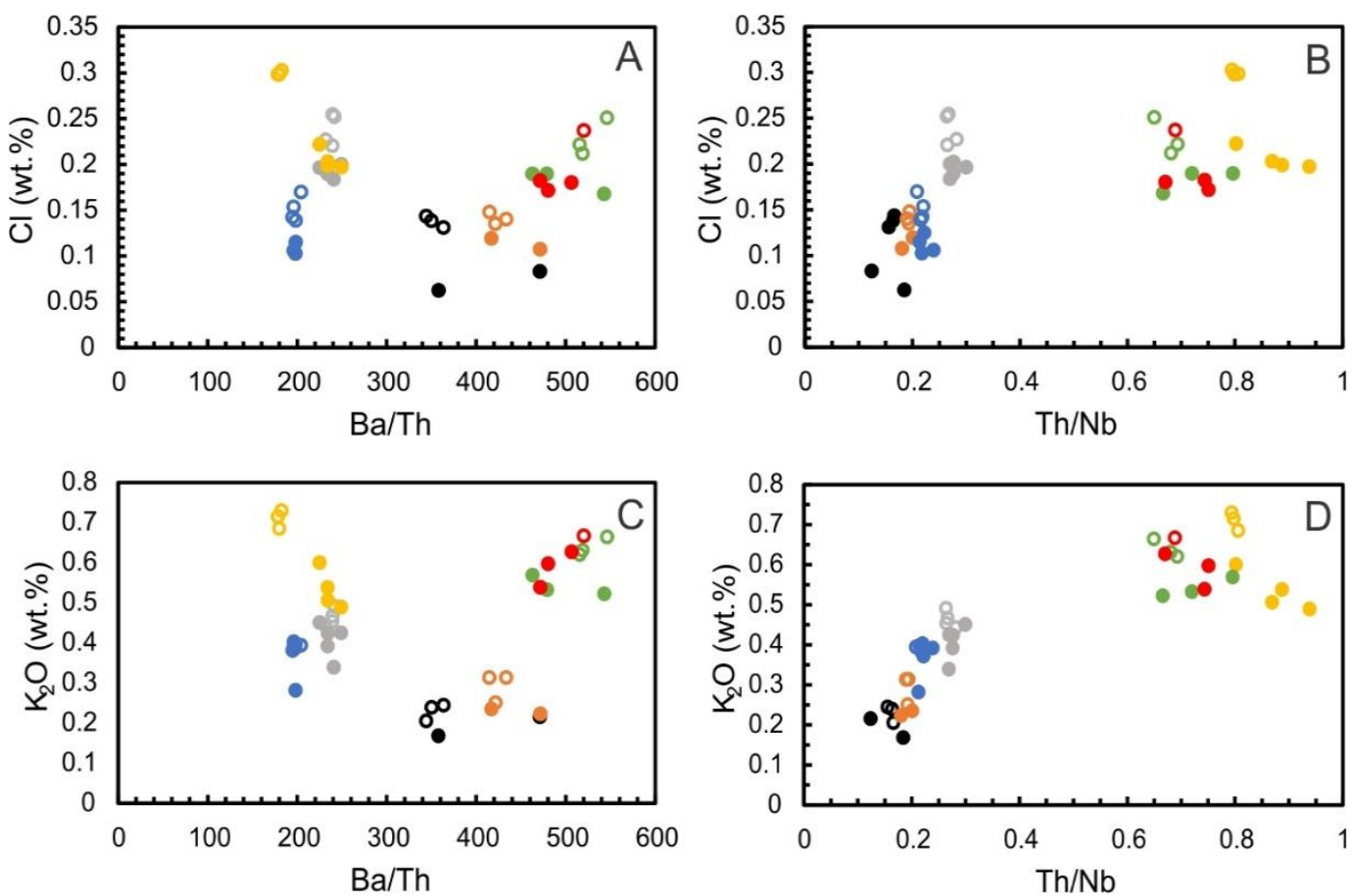

Figure 5.7: Alkali elements $\left(\mathrm{Cl} \& \mathrm{~K}_{2} \mathrm{O}\right)$ vs shallow $(\mathrm{Ba} / \mathrm{Th})$ and deep $(\mathrm{Th} / \mathrm{Nb})$ subduction components. $(\mathrm{A}) \mathrm{Cl}$ vs $\mathrm{Ba} / \mathrm{Th}$, (B) $\mathrm{Cl}$ vs Th/Nb, (C) $\mathrm{K}_{2} \mathrm{O}$ vs Ba/Th, and (D) $\mathrm{K}_{2} \mathrm{O}$ vs Th/Nb. 


\subsection{Metals in the SKAHT}

The overall metal contents in the Kermadec Arc - back-arc lavas reflect the combined influence of a number of variables, including source composition, degree of partial melting, fractional crystallisation and degassing processes, and crustal contamination. The preceding discussion has placed some constraints on such processes. This section explores how specific metals ( $\mathrm{Cu}, \mathrm{V}, \mathrm{Zn}, \mathrm{Pb}$, and $\mathrm{Mo}$ ) behave in the KAHT system setting. These metals are of particular interest due to their relatively high abundance in hydrothermal mineralization deposits, a notable feature of Rumble II West, Brothers and Clark volcanoes within the SKA.

\subsubsection{Metals during magma evolution}

Lead displays a general increase in concentration with increasing $\mathrm{SiO}_{2}$ (figure $5.8 \mathrm{C})$, consistent with incompatibility during crystal fractionation. Furthermore, the positive relationship flattens with increasing $\mathrm{SiO}_{2}$, with less variation in $\mathrm{Pb}$ contents beyond approximately 52 wt.\% $\mathrm{SiO}_{2}$, suggesting $\mathrm{Pb}$ becomes less incompatible within fractionating phases. Two distinct, subparallel trends are observed; high Pb defined by Basin I and Rumble III samples, and a lower Pb trend defined by Basin $\mathrm{D}$ and Rumble II West samples.

Vanadium and Mo show similar general trends, increasing in concentration with increasing $\mathrm{SiO}_{2}$ (figure $5.8 \mathrm{~B} \& \mathrm{E}$ ). This suggests both $\mathrm{V}$ and Mo behave incompatibly during crystal fractionation. A decrease in incompatibility of these metals within the melt is less apparent than $\mathrm{Pb}$, although Rumble III groundmass glasses also have lower $\mathrm{V}$ concentrations compared to melt inclusions (figure 5.8B). Vanadium and Mo show three distinct trends with $\mathrm{SiO}_{2}$; high $\mathrm{V}$ and Mo (Basin I and RIII-1;2), moderate V and Mo (Basin D and RIIW-3), and low V and Mo (RIIW-1 and RIIW-2). Zinc shows similar variations between localities but less passive enrichment via fractional crystallisation than $\mathrm{V}$ and Mo and more scatter (figure 5.8D).

Basin D glasses are the only samples to show significantly increasing $\mathrm{Cu}$ contents with increasing $\mathrm{SiO}_{2}$ (figure 5.8A). The $\mathrm{Cu}$ concentrations of other samples show relatively low variations, or scatter that does not correlate with $\mathrm{SiO}_{2}$. As with $\mathrm{Pb}$, 
V, Mo, and $\mathrm{Zn}$, Cu concentrations are higher for Basin I and Rumble III for a given $\mathrm{SiO}_{2}$ than Basin D and Rumble II West samples (figure 5.8B \& E), however RIIW-2 glasses have significantly higher $\mathrm{Cu}$, similar to RIII samples and are offset from the other Rumble II West samples. Copper contents in RIII-1 and 2 groundmass glasses slightly decreased relative to respective melt inclusions, similar to $\mathrm{V}$ and $\mathrm{Pb}$.

Overall, the trace metal behaviour is consistent with the elements being incompatible within the dominant fractionating crystal phases (olivine + clinopyroxene + plagioclase). This is consistent with calculated partition coefficients of basaltic systems in natural and laboratory settings (e.g., Bougault and Hekinian, 1974; Paster et al., 1974; Matsui et al., 1977; Klock and Palme, 1988; McKenzie and O’Nions, 1991; Hart and Dunn, 1993; Jenner et al., 1993; Hauri et al., 1994), excluding V which is slightly compatible in clinopyroxene, however this effect is likely minimal as all samples show increasing $\mathrm{V}$ concentrations with increasing $\mathrm{SiO}_{2}$ (figure 5.8B).

Based on the trends defined by Basin I glasses relative enrichment of each metal prior to approximately $52 \mathrm{wt} . \% \mathrm{SiO}_{2}$ are $\mathrm{Pb}, \mathrm{Cu}>\mathrm{Mo}>\mathrm{V}>\mathrm{Zn}$. There appears to be no systematic differences in metal behaviour between arc front and back-arc samples. Rather, from approximately $52 \mathrm{wt} . \% \mathrm{SiO}_{2} \mathrm{~Pb}$ and $\mathrm{Cu}$ and perhaps $\mathrm{Zn}$, appear to become less incompatible within the melt, likely the result of fractionating of a phase in which these elements are compatible, decreasing or mitigating the enrichment effects of removal of the main crystallising phases. More significant differences in metal contents occur between more southern samples (Basin I and Rumble III) and northern samples (Basin D and Rumble II West), which as for the lithophile elements discussed earlier, likely reflect source variations. These differences with be explored later in sections 5.3.2 and 5.3.3. 

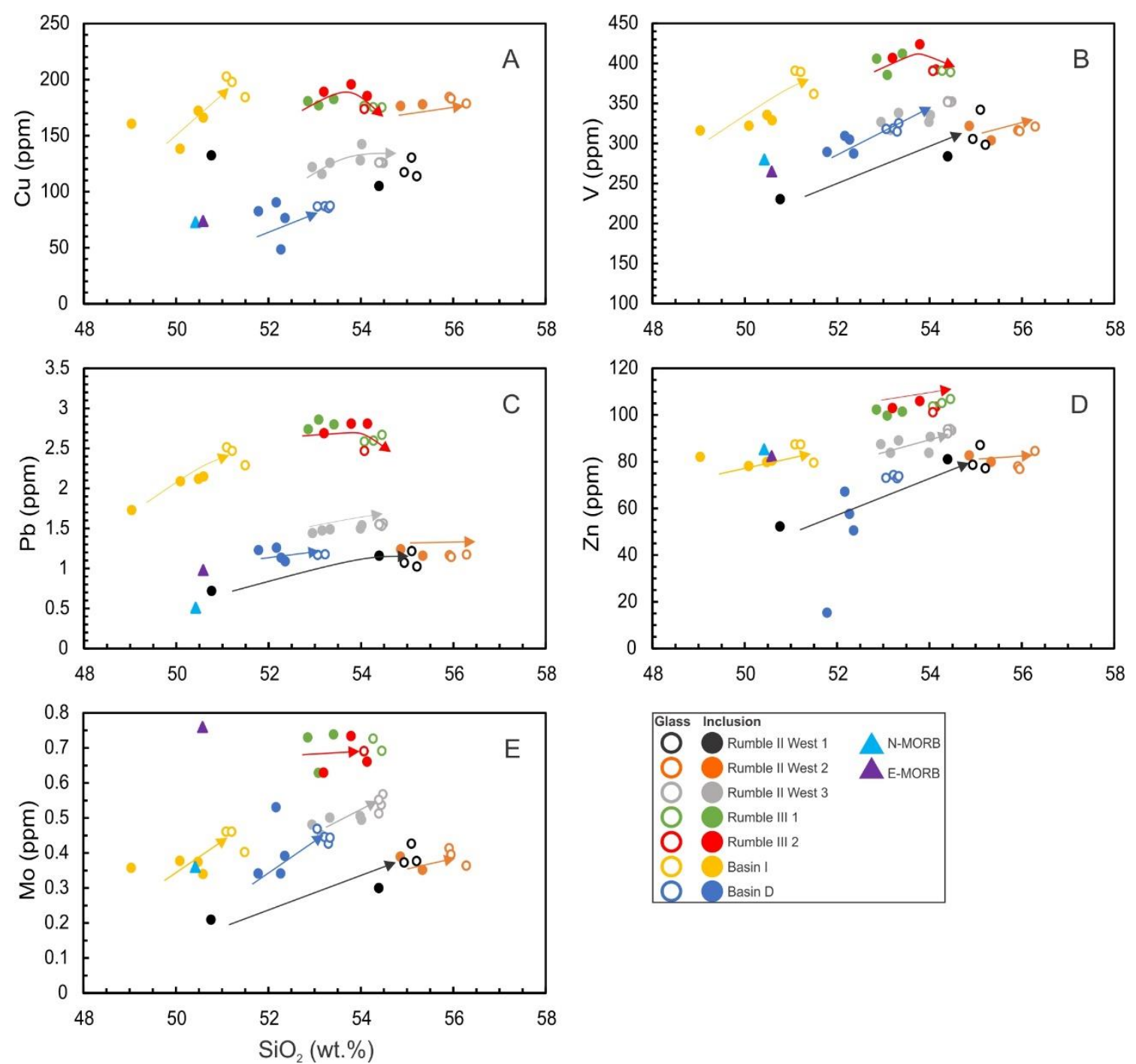

Figure 5.8: Bivariate element plots of (A) $\mathrm{Cu},(\mathrm{B}) \mathrm{V},(\mathrm{C}) \mathrm{Pb},(\mathrm{D}) \mathrm{Zn}$ and (E) Mo against $\mathrm{SiO}_{2}$. Coloured arrows indicate the general trends of metal abundances with increasing crystal fractionation. Note only Rumble III samples show systematic decreases (downwards trend) in $\mathrm{Cu}, \mathrm{V}$, and $\mathrm{Pb}$. Average N-MORB and E-MORB compositions are also shown.

A potential pathway for metal removal from the system is via degassing of volatile phases such as $\mathrm{CO}_{2}, \mathrm{H}_{2} \mathrm{O}, \mathrm{S}$, and potentially $\mathrm{Cl}$. It is expected that during the continual degassing of the magma, as evident by decreasing sulfur contents, metals may be removed from the melt by partitioning into volatile phases, carried predominantly as sulfide species. This has been suggested for CuS complexes (Heinrich et al., 1992, 1999, Pokrovski et al., 2005, 2008; Simon et al., 2006; Cauzid et al., 2007; Seo et al., 2009; Zajacz and Halter, 2009; Zajacz et al., 2010). However, elements with similar valences (e.g., V, Mo, Zn and Pb) may also be incorporated. The interplay of fractionation related enrichment (or depletion if a compatible phases crystallises) and degassing related depletion will cause metal abundances to either increase, or 
decrease, respectively, depending on their relative importance. The relationship between traces metals and sulfur contents may provide insights in potential metal loss due to sulfur species degassing.

Back-arc basins D and I as well as RIIW-1 and 3 show general increasing metal abundances with decreasing sulfur content (figure 5.9). Rumble II West-2 glasses show less metal content variance with decreasing sulfur, with no obvious increases in $\mathrm{V}, \mathrm{Zn}$, and Mo with decreasing Sulfur below 0.05 wt.\% sulfur. Rumble III-1 and 2 samples are the only to show significant decreases of $\mathrm{Cu}$ and $\mathrm{V}$ concentrations during late stage sulfur degassing, suggesting that these metals were potentially removed as sulfide complexes during magma degassing. However, given that only Rumble III samples display this trend there is likely a physiochemical difference between RIII magmas and those of the other sampled SKAHT localities. The late stage metal loss in Rumble III lavas, as shown by the groundmass glasses, may relate to eruption at significantly shallower depths at $\sim 250 \mathrm{mbsl}$ compared to $\sim 1300-2800 \mathrm{mbsl}$ of Rumble II West and the back-arc basins, respectively. Despite apparent late stage metal loss, Rumble III lavas generally have the highest trace metal contents of these SKAHT samples. The greater depths of Rumble II West and the back-arc basins may hinder late degassing and associated metal loss on eruption due to a higher hydrostatic pressure.

Together, metal trends with both $\mathrm{SiO}_{2}$ and $\mathrm{S}$, support competing effects of metals loss to devolatilisation, and enrichment due to incompatible crystal fractionation. The increases in trace metal concentrations are most significant in backarc basin samples, which display the least evolved samples and feature the majority of sulfur degassing from approximately $0.15-0.05$ wt.\% sulfur (figure 5.9). Metal elements are predominantly removed by $\mathrm{S}^{2-}$ species (Zajacz and Halter, 2009; Zajacz et al., 2010; Richards, 2011) suggesting that most sulfur degassing of these SKHAT lavas was likely dominated by the more oxidized species $\left(\mathrm{S}^{6+}\right)$. This is consistent with findings of Wysoczanski et al. (2012), whereby SKAHT melt inclusions generally had higher proportions of oxidised sulfur than respective pillow glasses. If $\mathrm{S}^{2-}$ dominated a smaller degree of metal enrichment or a net metal loss would be expected. Assuming mineral fractionation is constant, it would appear that the more evolved arc front magmas have greater metal losses compared to less evolved back-arc samples, as suggested by 
greater metal enrichment in back-arc samples, despite the majority of sulfur already being degassed from arc front glasses (figure 5.9).
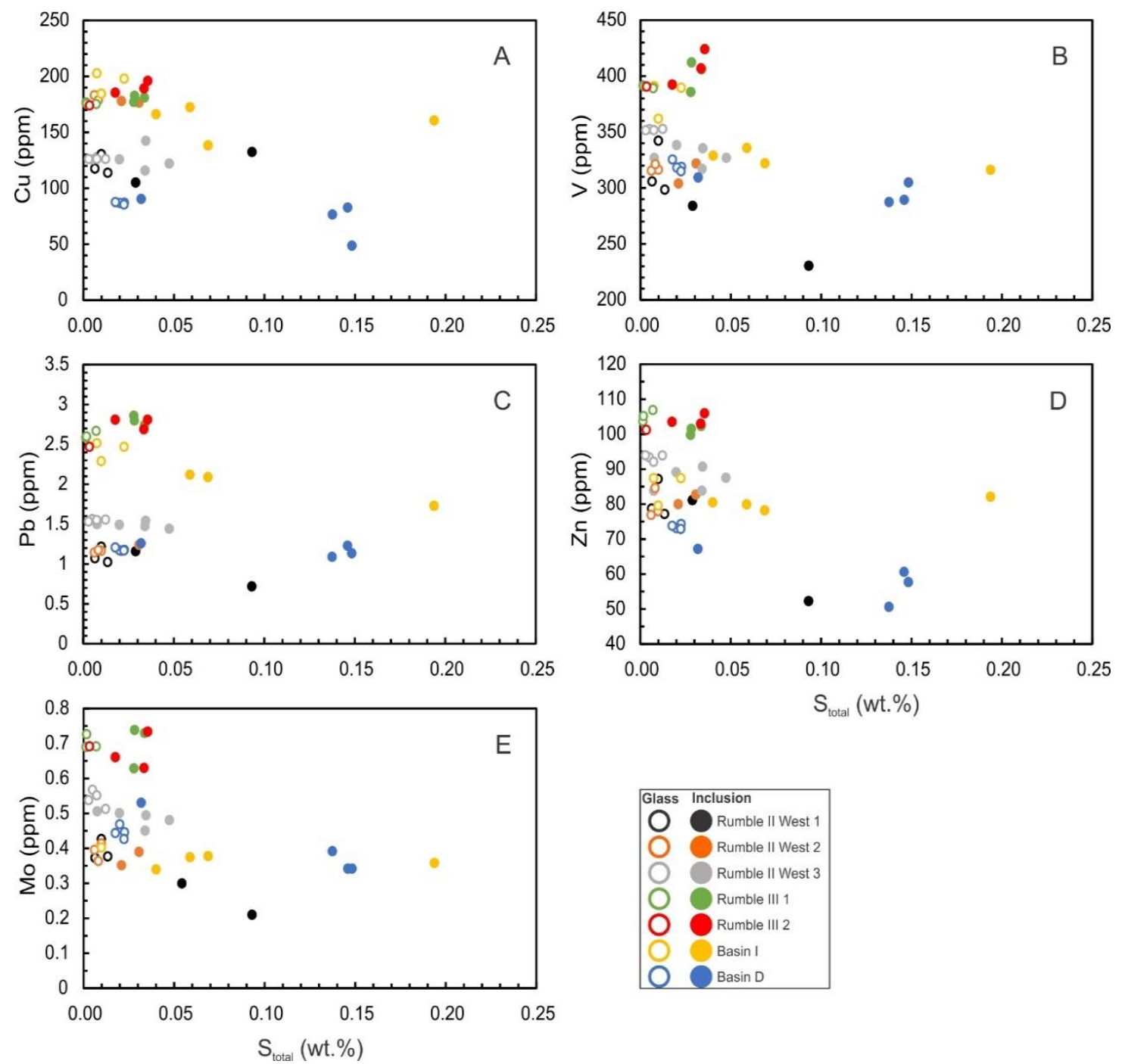

Figure 5.9: Bivariate element plots of select trace elements vs sulfur $\mathrm{total}_{\text {. }}(\mathrm{A}) \mathrm{Cu},(\mathrm{B}) \mathrm{V},(\mathrm{C}) \mathrm{Pb},(\mathrm{D}) \mathrm{Zn}$, and (E) Mo.

All samples featured comparable final sulfur contents within groundmass glasses, yet only the back-arc samples and RIIW-3 show significant increases in metal contents below 0.05 wt.\% sulfur (figure 5.9). Although sulfur speciation was not measured in these samples a decreasing $\mathrm{S}^{6+}$ content with sulfur degassing between melt inclusions and groundmass glass has been observed for other SKAHT glass samples, including from Rumble III, Rumble II West, and Havre Trough basalts (Wysoczanski et al., 2012). The variation in metal behaviours may be explained by more reduced melt conditions (higher $\mathrm{S}^{2-}$ proportions) within the more evolved arc 
front samples. A higher proportion of $\mathrm{S}^{2-}$ would result in greater propensity for metal removal from the melt as degassing metal sulfide complexes.

These trends are also similar to the early stage effects associated with magnetite fractionation (Jenner et al., 2010). This event may have a twofold effect on chalcophile and siderophile elements. Firstly, if a sulfide phase begins to fractionate, $\mathrm{Cu}$ and similar transition metals may be incorporated and removed from the melt. Secondly, the drive from a $\mathrm{S}^{6+}$ to $\mathrm{S}^{2-}$ dominated melt assists metal incorporation into a degassing volatile phase even if sulfide does not reach saturation. It is generally considered that magnetite crystallisation occurs in arc settings at $\sim 55-60$ wt. $\% \mathrm{SiO}_{2}$, or at an Mg number of $\sim 40$ (Jenner et al., 2010, 2015; Timm et al., 2012). This would likely mean that these SKAHT samples are not sufficiently evolved for significant magnetite fractionation that would result in significant decreases in trace metal concentrations. Due to the high abundances of $\mathrm{H}_{2} \mathrm{O}$, arc magmas are capable or a relatively early onsite of magnetite crystallisation (Jenner et al., 2010, 2015).

Therefore, samples with a recorded maximum $\mathrm{H}_{2} \mathrm{O}$ content of 3.1 wt.\% (representing a minimum water content) could feature an earlier crystallisation of magnetite fractionation. This is supported by negative correlation between $\mathrm{FeO}_{\text {total }}$ and $\mathrm{SiO}_{2}$ in the arc front lavas from Rumble III and Rumble II West from 52 wt.\% $\mathrm{SiO}_{2}$. However, magnetite fractionation and the related subsequent sulfide increase, if present must be relatively minor as trace metal concentrations between all samples do not show strong decreases. The flattening trends of metals in arc front samples are similar in composition and gradient, to those observed in other Kermadec Arc lavas at $\sim 53-55$ wt.\% $\mathrm{SiO}_{2}$ at the point of inflection prior to onset of significant $\mathrm{Cu}, \mathrm{V}$, and $\mathrm{Zn}$ depletion (figure 2.3; Timm et al., 2012).

There is also the possibility that metals were transported as chloride complexes despite $\mathrm{Cl}$ behaving incompatibly during crystal fractionation (figure 4.10K). The fractionation between sulfur and $\mathrm{Cl}$ is expected with continued magma degassing (Lesne et al., 2011; Blundy et al., 2015). Metal contents in the glass samples show generally positive relationships with $\mathrm{Cl}$ contents. However, Rumble III groundmass glasses display noted decreases in most metal contents relative to melt inclusions (figure 5.10). As no coinciding loss of $\mathrm{Cl}$ is apparent, the majority of metal loss cannot be attributed to $\mathrm{Cl}$ degassing. Metal transport appears to be dominated by sulfide 
complexes instead of chloride complexes (Heinrich et al., 1992, 1999, Pokrovski et al., 2005, 2008; Simon et al., 2006; Cauzid et al., 2007; Seo et al., 2009; Zajacz and Halter, 2009; Zajacz et al., 2010). For Au, Au-hydrosulfide complexes, stabilities are greatly increased by the presence of minor amounts of $\mathrm{KCl}$ or $\mathrm{NaCl}$ (Zajacz et al., 2010). Therefore, although $\mathrm{Cl}$ may not be a significant carrier itself, as noted by a lack of prominent degassing, it's incorporation, however minor, into volatile phases may play an important role in the sequestration of some metals from melt. Furthermore, the relationship of metals with both sulfur and $\mathrm{Cl}$, suggest metals are more likely lost to a fractionating volatile phase and not a crystalline phase such as a sulfide, especially given that these lavas are likely considerably far from $\mathrm{S}^{2-}$ saturation (Wallace et al., 2015).

In summary, there are clear fractionation effects impacting the concentrations of metal elements within these SKAHT glasses. The evidence suggests that the metals behave largely incompatibly during magma evolution and the fractionation of olivine + clinopyroxene + plagioclase. The exceptions to this are Rumble III samples, which display a relationship with sulfur consistent with $\mathrm{Cu}, \mathrm{V}$ (possibly $\mathrm{Pb}$ ) loss through degassing. Furthermore, although the metal behaviour with magmatic evolution is broadly consistent among the different samples, they form distinct subparallel trends that indicate that there are variations in metal concentrations related to different primary melt and mantle source compositions. 

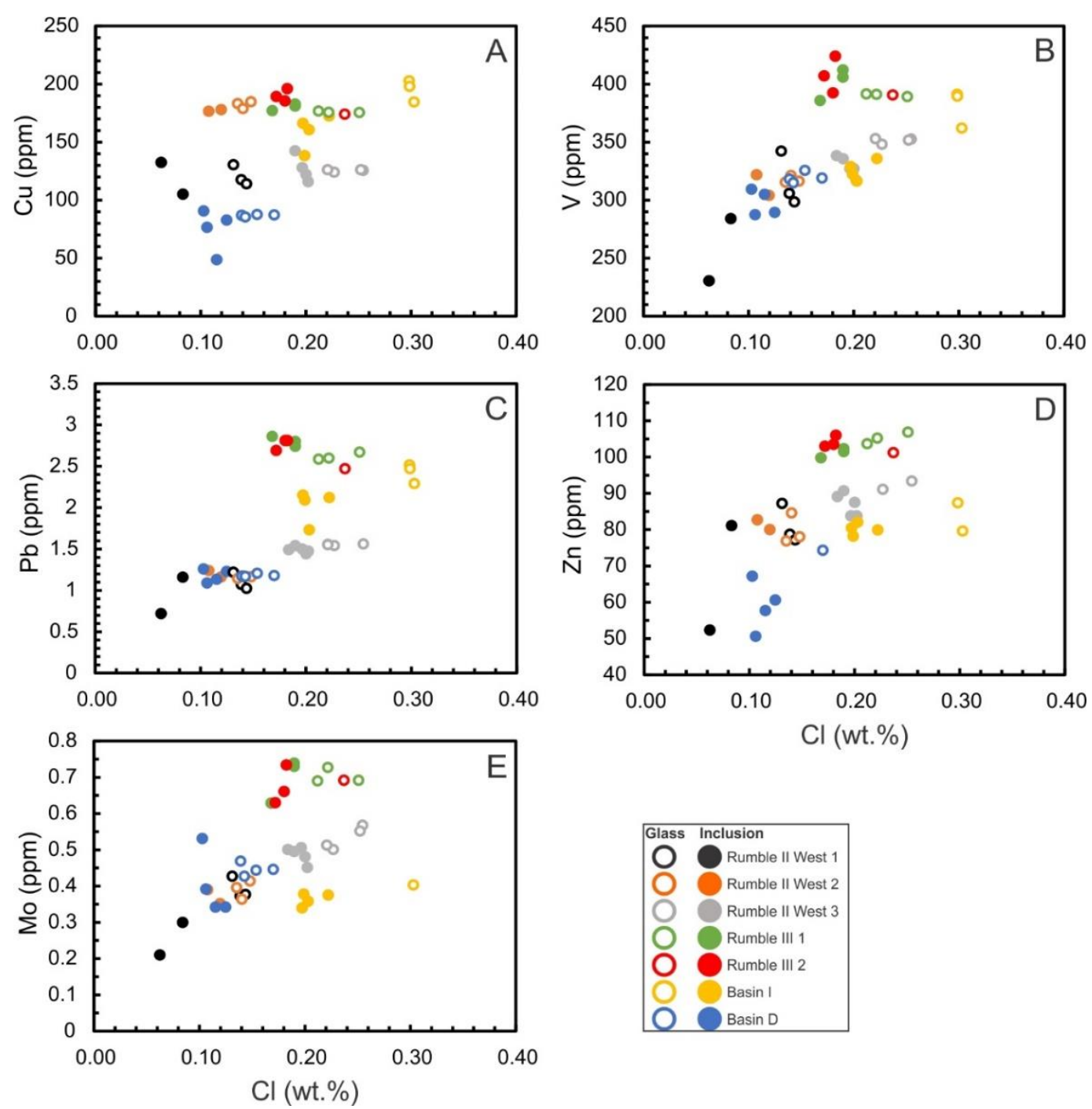

Figure 5.10: Bivariate element plots of select trace elements vs $\mathrm{Cl}(w t . \%) .(A) \mathrm{Cu},(B), \mathrm{V},(C) \mathrm{Pb},(\mathrm{D}), \mathrm{Zn}$, and (E) Mo.

\subsubsection{Metals and partial melting}

The effects of partial melting on metal concentrations are investigated here through the use of calculated degrees of partial melting (f) and reverse modelling of metal concentration to a standard MgO composition of $8 \mathrm{wt} . \%$. This method minimises the effect of crystal fractionation using Petrolog (Danyushevsky and Plechov, 2011).

Copper 8 shows strong positive relationships with degree of melting (figure $5.11 \mathrm{~A})$, suggesting that the degree of partial melting has considerable influence on $\mathrm{Cu}$ concentrations within primary melts. However, Basin I samples are offset to notably higher $\mathrm{Cu}_{8}$ values. A similar relationship is also shown by $\mathrm{V}_{8}$ and $\mathrm{Zn}_{8}$. Copper and $\mathrm{V}_{8}$ systematics are consistent with trends shown by other SKAHT glasses (Wysoczanski et al., 2012). Wysoczanski et al. (2012) suggested the behaviour of these metals indicates 
the presence of a $\mathrm{Cu}, \mathrm{V}$ bearing residual phase in the mantle sources. However, the positive relationship displayed by $Z \mathrm{n}_{8}$ here (figure 5.11D) is contradictory to $Z n_{8}$ contents observed in the SKAHT glasses analysed by Wysoczanski et al. (2012). Lead8 generally displays decreasing concentrations with increasing degree of melting for the Rumble II West and back-arc basin samples (figure 5.11C). This is consistent with other SKAHT glasses (e.g., Wysoczanski et al., 2012) and the incompatible behaviour of $\mathrm{Pb}$ within the mantle (Sun and McDonough, 1989; Gale et al., 2013). Rumble III glasses are offset from this trend however, with considerably higher $\mathrm{Pb}_{8}$ at higher degrees of melting.

As discussed (section 5.2) the effects of partial melting, source fertility and subduction components are all strongly interwoven, therefore relationships between degree of melting and metal 8 values may also be influenced by subduction inputs. This is likely the case for arc front localities, primarily Rumble III, which shows significant subduction derived inputs, including $\mathrm{Pb}$. As a result, the roles of the source compositions versus degree of partial melting can be difficult to deconvolve, and the role of subduction-derived components in metal concentrations needs to be explored.
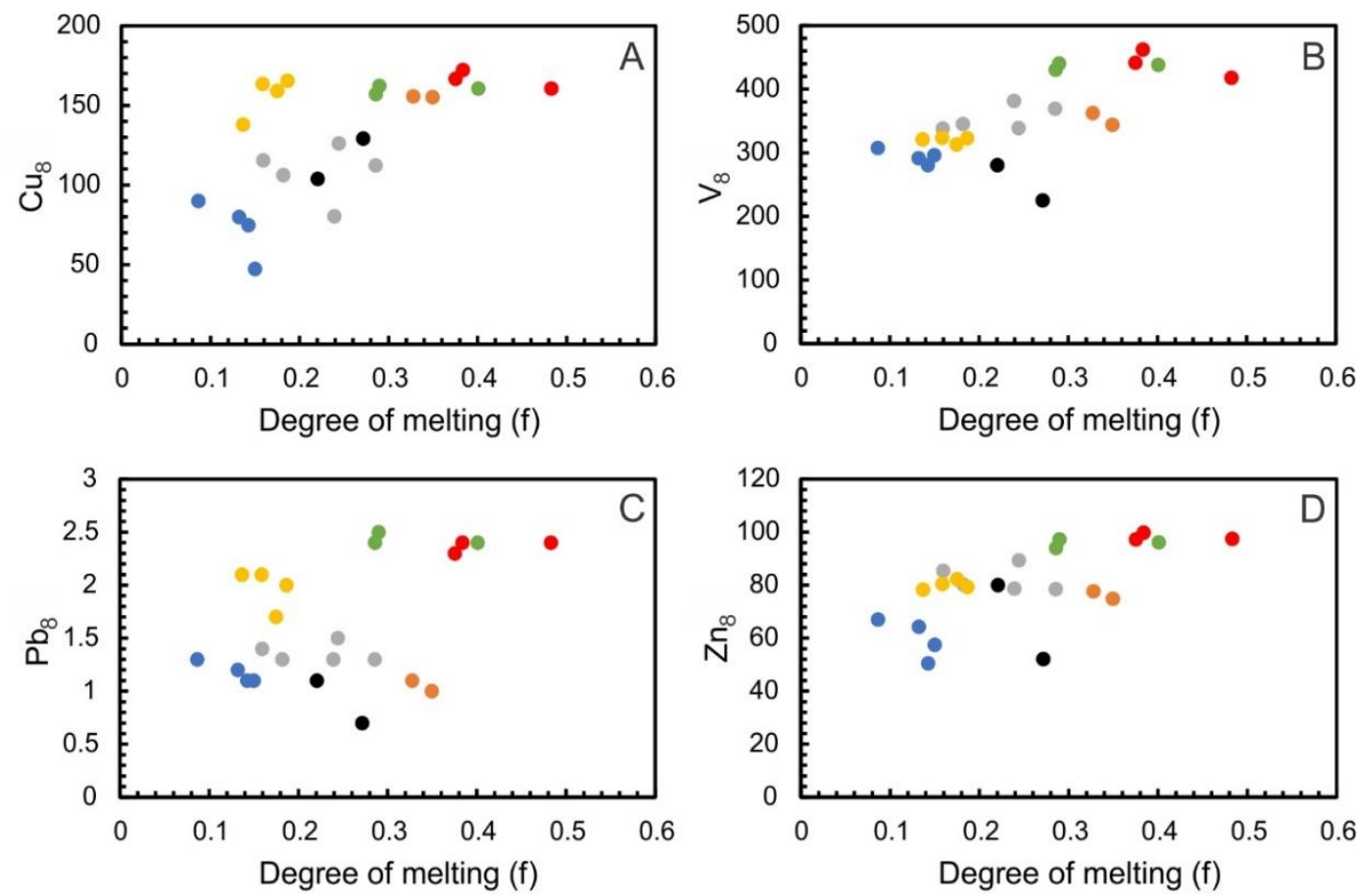

Figure 5.11: Modelled metal concentrations (ppm) at $8 \mathrm{wt} . \% \mathrm{MgO},(\mathrm{A}) \mathrm{Cu}_{8},(\mathrm{~B}) \mathrm{V}_{8}$, (C) $\mathrm{Pb}_{8}$, and $(D) \mathrm{Zn}_{8}$, against calculated degree of melting to investigate the effects of partial melting on metal concentrations.

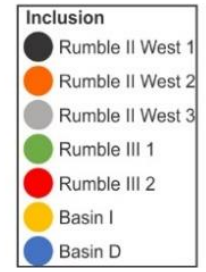




\subsubsection{Subduction related metal inputs}

As with investigating the effects of partial melting, the impacts of crystal fractionation need to be accounted for. The metals of interest ( $\mathrm{Pb}, \mathrm{Cu}, \mathrm{V}, \mathrm{Mo}, \mathrm{Zn}$ ) behave generally incompatibly in individual locations (figure 5.8). Therefore, a ratio of metals to another incompatible trace element (e.g., Yb; Timm et al., 2012) should mitigate the effects of fractionation, which can then be compared to ratio proxies of various subduction inputs.

The addition of $\mathrm{Pb}$ to the source of subduction zone magmas via slab-derived components has been well documented (e.g., Timm et al., 2012; Wysoczanski et al., 2012; Ryan and Chauvel, 2013). Compared to average N-MORB values (Melson et al., 2002; Gale et al., 2013), Pb/Yb is significantly enriched in the SKAHT glasses (figure 5.12). Enrichment varies from $\sim 2.6(\mathrm{RIIW}-1)$ to $\sim 7.7$ times (Basin I) N-MORB Pb/Yb values. Lead/Yb displays a general positive relationship with shallow subduction inputs (Ba/Th), excluding Basin I which is offset to high $\mathrm{Pb} / \mathrm{Yb}$ - low $\mathrm{Ba} /$ Th values (figure 5.12). There are distinct trends similar to those noted in metal versus $\mathrm{SiO}_{2}$ plots, whereby RIIW-1 is closely related to RIIW-2, and Basin D is similar to RIIW-3. Lead/Yb also appears strongly linked with a deep subduction component ( $\mathrm{Th} / \mathrm{Nb}$; figure 5.12). Given low $\mathrm{Ba} / \mathrm{Th}$ and high $\mathrm{Th} / \mathrm{Nb}$, the high $\mathrm{Pb} / \mathrm{Yb}$ values of Basin I samples indicate $\mathrm{Pb}$ in the Basin I melts is largely sourced from a deep subduction component. The larger shallow components of RIIW-1 and 2 samples compared to RIIW-3 and Basin D samples, with comparable $\mathrm{Pb} / \mathrm{Yb}$ values suggests that deep subduction components may be at least as effective for introducing $\mathrm{Pb}$ to the mantle as shallow aqueous components. The two southern localities (Rumble III and Basin I) have higher Pb concentrations overall than the northern localities (figure 4.10), consistent with overall higher slab-components, both deep and shallow, (section 5.2.3). For example, Rumble III glasses have a much higher shallow subduction component coupled with significantly higher $\mathrm{Pb} / \mathrm{Yb}$ compared to Rumble II West samples 1 and 2, despite relatively similar Ba/Th values.

It should be noted, however, that the arc front mantle sources (RIII-1 and 2 and RIIW-1 and2) are considerably less fertile (figure 5.4A) relative those of the back-arc and RIIW-3 samples, with a likely significant depletion of $\mathrm{Pb}$ prior to aqueous fluid input. Thus, the $\mathrm{Pb}$ enrichment via subduction inputs are likely to be greater than indicated by the relationships between $\mathrm{Pb} / \mathrm{Yb}$ and $\mathrm{Ba} / \mathrm{Th}$ and $\mathrm{Th} / \mathrm{Nb}$ for Rumble III and 
RIIW-1 and 2 glasses. This reasoning is consistent with the known high aqueous fluid mobility of $\mathrm{Pb}$ (Pearce and Stern, 2006; Wysoczanski et al., 2012). Additional Pb/Yb enrichment of back-arc and RIIW-3 may also be due to higher apparent sediment melt ([La/Sm $\left.]_{n}\right)$ within these samples (figure 5.12).

Copper/Yb systematics with subduction zone inputs are broadly similar to $\mathrm{Pb} / \mathrm{Yb}$ (figure 5.12). All samples show enrichments of $\mathrm{Cu} / \mathrm{Yb}$ relative to average $\mathrm{N}$ MORB, from $\sim 1.03-1.5$ (Basin D) to $~ 3.6-4.4$ times (Basin I) average N-MORB $\mathrm{Cu} / \mathrm{Yb}$, however the back-arc basins show significant scatter (figure 5.12). RIIW-2 glasses and one RIIW-1 sample show generally higher $\mathrm{Cu} / \mathrm{Yb}$ values than RIIW-3 glasses. This may be the result of a Cu enriched mantle source, or alternatively by the melt intercepting a metal-enriched zone at shallower depths. The latter possibility is consistent with the presence of hydrothermal activity and VMS deposits at Rumble II West (e.g., Leybourne et al., 2012). The Cu/Yb values for all samples excluding Basin I, correlated best with a shallow subduction input, however mobility within the deep component is also likely, and dominates in Basin I samples (figure 5.12). Unlike $\mathrm{Pb} / \mathrm{Yb}$, $\mathrm{Cu} / \mathrm{Yb}$ should be less influenced by relative mantle fertility of the back-arc versus arc front samples. Copper appears to have behaved compatibly during partial melting (section 5.3.2) and will be less fractionated from the slightly incompatible $\mathrm{Yb}$ than the highly incompatible $\mathrm{Pb}$ during partial melting.

Zinc/Yb values relative to average N-MORB range from $\sim 0.97$ (Basin D) to 1.9 times (Basin I; figure 5.12). The $\mathrm{Zn} / \mathrm{Yb}$ of arc front samples excluding RIIW-3, correlate most strongly with a shallow subduction input, whereas the back-arc basins and RIIW-3 samples show little correlation with $\mathrm{Ba} / \mathrm{Th}$. There is a slight positive correlation between $\mathrm{Th} / \mathrm{Nb}$ and $\mathrm{Zn} / \mathrm{Yb}$ amongst all samples, which is more apparent amongst the northern locations (Rumble II West and Basin D) than the southern locations (Rumble III and Basin I; figure 5.12). These relationships suggest that $\mathrm{Zn}$ is potentially introduced into the mantle wedge by both shallow and deep subduction components, with again, greater deep components influencing the two more southern localities. Vanadium/Yb relationships with subduction components are notably similar to $\mathrm{Zn} / \mathrm{Yb}$ with slightly higher enrichments relative to N-MORB, with $\sim 1.2$ (RIIW-1) to 2.2 (Basin I) times N-MORB values (figure 5.12). Despite the correlation between both $\mathrm{Zn} / \mathrm{Yb}$ and $\mathrm{V} / \mathrm{Yb}$ and a shallow subduction input in arc front samples, laboratory studies have 
shown that $\mathrm{Zn}$ and $\mathrm{V}$ are significantly less fluid mobile than $\mathrm{Pb}$ and $\mathrm{Cu}$ (e.g., Kogiso et al., 1997). Kogiso et al. (1997) reported that during dehydration of amphibolite (representative of oceanic crust) at $5.5 \mathrm{GPa}$ and $900^{\circ} \mathrm{C}$ that $\mathrm{Pb}$, and $\mathrm{Cu}$ abundances were reduced by up to 85 and $50 \%$, respectively, whereas, $\mathrm{Zn}$ and $\mathrm{V}$ only decreased by $3.7 \%$ and $7.1 \%$, respectively. Timm et al. (2012) suggest that a significant control on $\mathrm{Zn}$ and $V$ enrichment systematics between arc front and back-arc lavas may be the variable oxidation states which is commonly greater in the arc front than back-arc magmas (Jugo, 2009; Kelley et al., 2009; Wallace and Edmonds, 2011). Variability in oxidation state is likely to have a greater influence over $V$ as it becomes more significantly incompatible within the mantle at higher oxygen fugacity, transitioning from $\mathrm{V}^{2+}$ and $\mathrm{V}^{3+}$ to $\mathrm{V}^{4+}$ and $\mathrm{V}^{5+}$ (Lee et al., 2003). However, the overall influence of aqueous fluids on the transport of $\mathrm{Zn}$ and $\mathrm{V}$, either directly or through increasing oxidation state, is limited, based on their lower (to no) enrichment relative to $\mathrm{N}$ MORB, compared to those of $\mathrm{Pb}$ and $\mathrm{Cu}$.

Molybdenum/Yb enrichment relative to average N-MORB range from $\sim 1$ (RIIW-1) - 2.5 times (Rumble III; figure 5.12). Molybdenum/Yb broadly increases within arc front samples (excluding RIIW-3) with increasing shallow and deep subduction components. Basins I and D as well as RIIW-3 glasses show near identical Mo/Yb values. The relatively strong correlation between $\mathrm{Mo} / \mathrm{Yb}$ and a shallow subduction component in Rumble II West -1 and 2 and Rumble III samples suggest any Mo enrichment is primarily related to the shallow aqueous fluid release from the subducting slab (figure 5.12). Unlike other metals, the southern localities, Basin D and Rumble III, show a negative correlation between $\mathrm{Mo} / \mathrm{Yb}$ and a deep slab component, suggesting Mo is not significantly affected by this component. Similar to $\mathrm{Zn} / \mathrm{Yb}$, the Mo/Yb of the back-arc basins and RIIW-3 are only minimally enriched relative to MORB compositions (figure 5.12). However, Basins I and D as well as RIIW-3 samples feature higher Mo/Yb with comparable $\mathrm{Nb} / \mathrm{Yb}$ relative to $\mathrm{N}-\mathrm{MORB}$ (figure 5.4A; figure 5.12). This indicates that some Mo enrichment by subduction processes is likely required as most samples contain higher Mo contents than average N-MORB (figure 4.10E) 

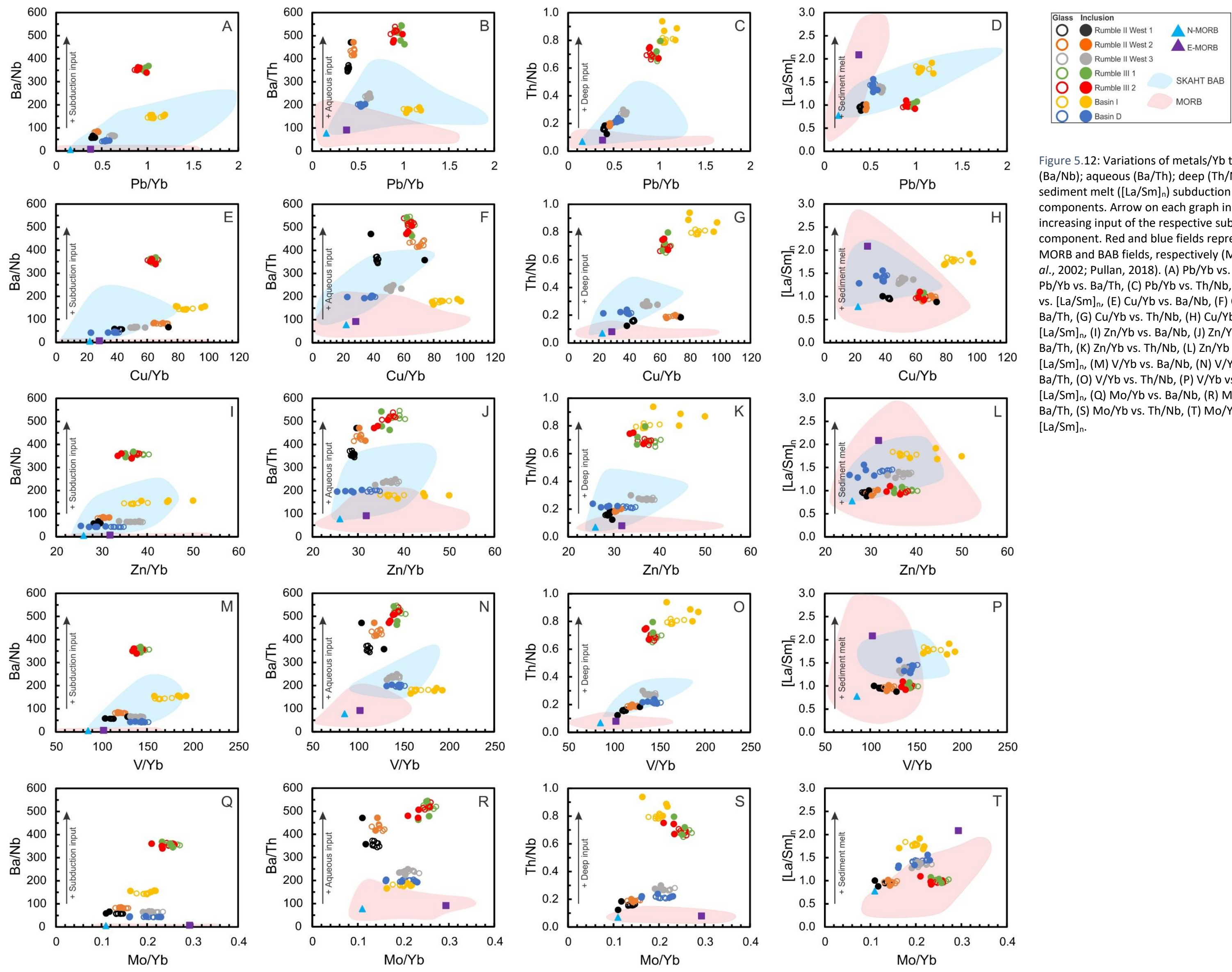

Figure 5.12: Variations of metals/Yb to total (Ba/Nb); aqueous (Ba/Th); deep (Th/Nb); and sedment mett $\left([\mathrm{La} / \mathrm{Sm}]_{\mathrm{n}}\right)$ subduction

increasing. A

component Red and blue fields represent

MORB and BAB fields, respectively (Melson et

al., 2002; Pullan, 2018). (A) Pb/Yb vs. Ba/Nb (B)

$\mathrm{pb} / \mathrm{Yb}$ vs. Ba/Th, (C) Pb/Yb vs. Th/Nb, (D) Pb/Yb

vs. [La/Sm] $]_{n}$, (E) Cu/Yb vs. Ba/Nb, (F) Cu/Yb vs.

Ba/Th, (G) Cu/Yb vs. Th/Nb, (H) Cu/Yb vs.

$[\mathrm{L} / \mathrm{Sm}]_{n,}$, (I) Zn/Yb vs. Ba/Nb, (J) Zn/Yb vs.

$\mathrm{Ba} / \mathrm{Th},(\mathrm{K}) \mathrm{Zn} / \mathrm{Kb}$ vs. Th/Nb, (L) Zn/Ybus.

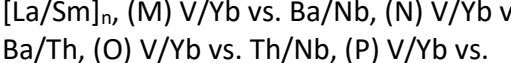

$[\mathrm{La} / \mathrm{Sm}]_{n},(\mathrm{Q}) \mathrm{Mo} / \mathrm{Vb} \mathrm{vs}$. Ba/Nb, (R) Mo/Yb vs.

$\mathrm{Ba} / \mathrm{Th}$, (S) Mo/Yb vs. Th/Nb, (T) Mo/Yb vs.

$\mathrm{Ba} / \mathrm{Th}, \mathrm{S}(\mathrm{S}) \mathrm{Mo/}$
$[\mathrm{La} / \mathrm{Sm}] \mathrm{n}$.

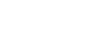


In summary, $\mathrm{Pb}, \mathrm{Cu}, \mathrm{V}, \mathrm{Zn}, \mathrm{Mo} / \mathrm{Yb}$ values for most SHAHT glasses are variably enriched relative to an average N-MORB composition. Overall relative enrichments in the metals can be summarised as $\mathrm{Pb}>\mathrm{Cu}>\mathrm{Mo}, \mathrm{V}>\mathrm{Zn}$. These enrichments are due to an interplay of influences including relative mantle fertility, degree of partial melting, and subduction related metasomatism of the mantle wedge. As these processes are inextricably linked to one another, as previously discussed, unequivocally separating the relative effects of each process on each metal is difficult.

The relative enrichment of trace metals found here is comparable and consistent with that reported from other SKAHT magmas (e.g., Timm et al., 2012; Wysoczanski et al., 2012). Wysoczanski et al. (2012) found similar relative enrichment trends of $\mathrm{Pb}>>\mathrm{Cu}>\mathrm{Zn}$, with $\mathrm{Pb}$ being primarily supplied by slab-derived fluids, consistent with the correlations between $\mathrm{Pb} / \mathrm{Yb}$ and shallow subduction processes of this study. The notably high $\mathrm{Pb}_{8}$ values (figure $5.11 \mathrm{C}$ ) of Rumble III samples are therefore, most likely the result of the high aqueous fluid input, decoupling $\mathrm{Pb}$ concentrations from depletion effects of higher degrees of partial melting.

Enrichments in the other metals are much less pronounced than for $\mathrm{Pb}$, indicating subduction inputs play a much subtler role for these metals, particularly Zn. Nonetheless, there is evidence for enrichments in all metals that correlated with slabderived components. It should be noted, however, that for $\mathrm{Zn}, \mathrm{Mo}$ and $\mathrm{V}$ in particular, apparent correlation with slab-derived components may result from increased mobility (incompatibility) during partial melting in a more oxidised enrichment than direct addition of these metals via the slab-derived component (e.g., Timm et al., 2012) and/or by larger degrees of partial melting enabled by fluid-flux melting.

\subsection{SKAHT metals and VMS deposits}

The likelihood of VMS deposit formation for these SKAHT magmatic centres cannot be entirely addressed without considering controls over heat generation, hydrothermal flows, fault systems, as well as a greater understanding of magma venting activity, which is beyond the scope of this study. However, a metal rich substrate, such as a cooled igneous body or erupted material is a key requirement for the formation of VMS deposits, and some constrains can be made. It has been noted 
that in black smoker fluids, transitional metal concentrations are lower than expected for mineral estimated solubilities in the reaction zone (German and Von Damm, 2003). This may indicate that hydrothermal fluids are undersaturated in trace metals which would explain the strong correlation between metals contents within the source volcanic rock and the associated VMS deposit (e.g., Hannington, 2014). By identifying how metal enrichment occurred in SKAHT melts, an association can be established between which magmatic variables would likely result in more metalliferous VMS deposits.

The strong correlation between total subduction inputs and trace metal concentrations suggests this a significant method of metal enrichment and variability between locations at a given arc. Therefore, VMS hydrothermal systems hosted in volcanic rocks with melt sources that are more strongly enriched by subduction related mantle metasomatism would be expected to contain higher metal contents (of at least $\mathrm{Cu}, \mathrm{V}, \mathrm{Mo}, \mathrm{Zn}$, and $\mathrm{Pb}$ ) compared with volcanic rocks with lesser or no subduction enrichments, assuming all other factors were equal. From the localities samples here, it is apparent that arc-parallel variations can be significant, with consistently higher concentrations of metals (and subduction related metasomatism) observed in the two more southern sites: Rumble III and Basin D.

Partial melting and source fertility are also important factors in determining trace metal enrichment. In these factors, $\mathrm{Pb}$ appears to behave differently to the other metals investigated. Higher $\mathrm{Pb}$ contents in the melts are broadly favoured by more fertile sources and lower degrees of partial melting. Conversely, the more compatible behaviour of $\mathrm{Cu}, \mathrm{Zn}, \mathrm{V}$ and Mo, mean higher concentrations in the melt will be favoured by less fertile sources and larger degrees of partial melting. The degree of partial melting in arc settings is expected to closely correlated with subduction inputs. Therefore, the relative depletion of incompatible highly fluid mobile elements (e.g., $\mathrm{Pb}$ ) due to higher degrees of partial melting is likely to be readily negated by subduction related inputs.

Another important control of metal content within melts is enrichment of depletions caused by crystal fractionation and volatile degassing. Metals within SKAHT lavas are predominantly enriched during early stage magma evolution (figure 5.8). However, substantial loss of trace metals occurs with the onset of metal-compatible 
fractionating phases (e.g., sulfide minerals or volatile phases; e.g., Jenner et al., 2010, 2015; Timm et al., 2012). This may imply that basaltic andesite compositions, where metal contents appear to peak (e.g., figure 5.8), are likely to enhance metal contents in associated hydrothermal deposits. The resulting loss of metals from melt may not necessarily negatively impact VMS deposits as long as bulk rock metal content through the hydrothermal flow path and reaction zone is not decreased (figure 1.3). No net loss of metals requires fractionating sulfides to predominantly remain within lavas, although these phases are likely to be retained at the base of the crust, and may thus be isolated from upper-crustal hydrothermal processes (Cooke et al., 2013). A higher oxygen fugacity, which limits $\mathrm{SO}_{2}$ saturation, would extend metal retention within the lava, to be transported to shallower crustal depths.

The effects metal loss to volatiles phases relating to VMS deposits is less certain. Sulfur degassing is a primary method of porphyry deposit formation, which may concentrate metals within the upper crust, however moving metals from the primary reaction zone may reduce the ability for metals to be incorporated within hydrothermal fluids. Alternatively, the addition of magmatic fluids, or other sources of metals has been invoked to explain larger, or higher grade, VMS deposits (Urabe, 1987; Stanton, 1990, 1994; Large et al., 1996; Scott, 1997; Yang and Scott, 2006). The necessity of other inputs relates to the requirement of both relatively substantial regions for metal leaching, and a subvolcanic heat source. Hannington (2014) estimated that for an average VMS deposit a reasonable source region may be on the order of $100 \mathrm{~km}^{3}$ and requiring a similarly sized heat source to circulate and heat $\left(1^{\circ} \mathrm{C}-\right.$ $350^{\circ} \mathrm{C}$ ) the necessary hydrothermal fluid (assuming concentration of only $1-5 \mathrm{ppm} \mathrm{Cu}$ and 5-10 ppm Zn in the fluid). Therefore, magmatic systems with substantial loss of trace metals by degassing may promote higher grade VMS deposits, favouring melts with higher volatile contents.

Of the locations studied here, both Rumble III and Rumble II West are known to be hydrothermally active, however the formation of VMS deposits has only been observed for Rumble II West. If conditions were favourable for the formation of a VMS deposit at Rumble III however, it may be notably richer in the metals investigated here than an equivalent Rumble II West deposit. 
Chapter 6: Conclusions 


\subsection{Concluding Points}

The sample locations investigated in this study of select SKAHT stratovolcanoes and back-arc basins show evidence for significant variations in primary melt compositions due to varying degrees of mantle fertility, partial melting and subduction component enrichment.

Broad back-arc to arc front spatial variations are evident. Back-arc basins D and I (including RIIW-3) samples are the result of lower degrees of partial melting of more fertile mantle enriched with relatively minor amounts shallow subduction components. The reverse is generally true for arc front samples (Rumble II West, samples-1 and 2 and Rumble III). Degree of melting and mantle fertility are strongly related to distance from the trench, due to both increased aqueous fluid input from the subducting slab triggering higher degrees of fluid flux melting, as well as mantle wedge convection, cycling more fertile mantle from the back-arc to the arc front. The interplay between these processes makes it difficult to attribute element enrichments within arc lavas specifically to either of these processes.

The sample locations were selected to sample a trench-perpendicular transect across the arc. However, it is apparent from the composition trends in the analysed glasses that the offset of Basin I and Rumble III volcano to the south of Rumble II West volcano and Basin $D$, was sufficient to tap significant lateral variations in the mantle. Melts from Basin I and Rumble III are generally more enriched in metal elements, due to a relatively high shallow subduction component within the source of Rumble III melts, and significant deep subduction components in the source of both Rumble III and Basin I melts. Considerably greater deep subduction components in both Rumble III and Basin I glasses compared to Rumble II West and Basin D samples, indicate that lateral variations along the strike of the trench can be as significant as trench perpendicular variations.

Rumble II West samples highlight how a single volcano can tap compositionally distinct sources, with glasses reflecting both relatively enriched and depleted mantle melts, with variable degrees of mantle melting and subduction related enrichments. Furthermore, magma mixing is evident from RIIW-1 inclusions, with compositions of 
individual melt inclusions varying between compositions similar to RIIW-2 and Basin I/RIIW-3 melts.

The SKAHT melts are variably enriched in trace metals relative to N-MORB, in the order $\mathrm{Pb}>>\mathrm{Cu}>\mathrm{Mo}, \mathrm{V}>\mathrm{Zn}$. Correlations between subduction component proxies $(\mathrm{Ba} / \mathrm{Th}$ and $\mathrm{Th} / \mathrm{Nb})$ and metals/Yb suggest that these enrichments are at least partially and variably related to subduction related metasomatism of the ambient mantle source. Lead, and to a lesser extent $\mathrm{Cu}$ and Mo, are predominantly carried within hydrous shallow subduction components, however $\mathrm{V}$ and $\mathrm{Zn}$ are increasingly mobilized during partial melting of the mantle wedge by increased oxygen fugacity and/or higher degrees of partial melting caused by the addition of aqueous fluids. The degree of partial melting is likely to exert significant control over $\mathrm{Cu}$ and $\mathrm{V}$ enrichment.

Crystal fractionation during magma evolution led to further enrichment of $\mathrm{Pb}$, $\mathrm{Cu}, \mathrm{Mo}, \mathrm{V}$ and $\mathrm{Zn}$ within the SKAHT glasses between approximately $50-56 \mathrm{wt} . \% \mathrm{SiO}_{2}$. However, from 52-56 wt.\% $\mathrm{SiO}_{2}$ enrichment in $\mathrm{Pb}$ and especially $\mathrm{Cu}$ decreases or shows no significant increase. This is mostly likely associated with increased metal loss via the degassing of volatiles phases, which incorporate metals as predominantly sulfide complexes and potentially the onset of magnetite fractionation.

Magmatic systems with higher slab derived subduction components (e.g., arc front stratovolcanoes) should be more optimal for the development of higher grade VMS deposits although Basin I glasses illustrate that back-arc localities may also be significantly enriched in base metals. Additionally, the observed along arc strike variation in metal enrichment between Rumble II West and Rumble III volcanoes suggests the VMS deposits developed in the same subduction zone may vary significantly in metal enrichment. 


\subsection{Suggestions for future studies}

This study investigated the sources, abundances, and behaviour of trace metals within SKAHT arc front stratovolcanoes and back-arc basins. In addition to the conclusions summarised above, the study has highlighted limitations in the approach undertaken here. The following are suggestions for future work.

1) Significant compositional variations, relating to source variations, within individual sample locations (e.g., RIIW-1) indicates this is an aspect that would benefit from more extensive sampling from individual locations. This may allow for improved understanding on how individual magmatic systems may tap variable sources, and the roles of magma mixing and recharge at arc front volcanoes.

2) A greater number of sampled inclusions covering a wider range $\mathrm{SiO}_{2}$ and $\mathrm{MgO}$ contents would significantly improve resolution of trace metal and volatile behaviour during magma evolution. Relatively primitive melt compositions are missing from the majority of the arc front samples studied here. As the Rumble III samples contained both the lowest proportions of phenocrysts phases and the smallest range in the melt inclusion $\mathrm{SiO}_{2}$ contents, targeting more phenocryst-rich lavas may prove more fruitful. Conversely, extending analysis to more evolved lavas from the same localities, if available may better capture onset of metal loss accompanied by degassing and magnetite crystallisation.

3) Similarly, this study could be improved with more volatile analyses (e.g., $\mathrm{H}_{2} \mathrm{O}$ and $\mathrm{CO}_{2}$ ). The measured $\mathrm{H}_{2} \mathrm{O}$ abundances feature considerable scatter, limiting interpretations relating to $\mathrm{H}_{2} \mathrm{O}$ degassing and metal behaviour. Furthermore, if more primitive inclusions, with measurable $\mathrm{CO}_{2}$ abundances could be analysed, more accurate minimum $\mathrm{H}_{2} \mathrm{O}$ contents of the arc magmas could be determined. $\mathrm{H}_{2} \mathrm{O}$ abundances and variations from arc front stratovolcanoes to back-arc basins would be useful for better understanding potential relationships between subduction inputs and volatile contents. 
4) Investigations of variations in sulfur speciation related to both arcperpendicular distance from the trench and magmatic evolution are relatively limited within literature, and direct measurement of oxidation states of SKAHT magmas (e.g., by XANES or EPMA) would add valuable constraints to the interpretations of metal and volatile behaviour.

5) Radiogenic isotope ratios ( $\mathrm{Sr}, \mathrm{Pb}, \mathrm{Nd}, \mathrm{Hf}$ ) have been successfully employed in arc systems for fingerprinting different slab derived components, and the sources of the respective elements. Stable isotopes of the metals of interest may potentially shed light on different processes affecting their behaviour in the subduction system. This would most likely require bulk rock analysis however.

6) This study focusses primarily on spatial variations, between arc front and backarc magmatism, however a temporal element is missing. If relative ages of lavas from single edifices or basins, or better yet absolute age differences constrained by dating techniques, could be established, temporal relationships relating to variable subduction inputs or conditions within the crust affected magma evolution, could be explored. 


\section{References}

Abers, G., van Keken, P., Kneller, E., Ferris, A. \& Stachnik, J. (2006). The thermal structure of subducting zones constrained by seismic imaging: Implications for slab dehydration and wedge flow. Earth and Planetary Science Letters, 241(3-4), 387-397.

Aiuppa, A., Baker, D. R. \& Webster, J. D. (2009). Halogens in volcanic systems. Chemical Geology, 263(1-4), 1-18.

Bach, W., Hegner, E. \& Erzinger, J. (1998). Chemical fluxes in the Tonga Subduction Zone: Evidence from the Southern Lau Basin. Geophysical Research Letters, 25(9), 1467-1470.

Barker, S. J., Wilson, C. J. N., Baker, J. A., Millet, M. A., Rotella, M. D., Wright, I. C. \& Wysoczanski, R. J. (2013). Geochemistry and petrogenesis of silicic magmas in the Intra-Oceanic Kermadec Arc. Journal of Petrology, 54(2), 351-391.

Bassett, D., Kopp, H., Sutherland, R., Henrys, S., Watts, A. B., Timm, C., Scherwath, M., Grevemeyer, I. \& de Ronde, C. E. J. (2016). Crustal structure of the Kermadec arc from MANGO seismic refraction profiles. Journal of Geophysical Research: Solid Earth, 121(10), 7514-7546.

Bassett, D., Sutherland, R., Henrys, S., Stern, T., Scherwath, M., Benson, A., Toulmin, S. \& Henderson, M. (2010). Three-dimensional velocity structure of the northern Hikurangi margin, Raukumara, New Zealand: Implications for the growth of continental crust by subduction erosion and tectonic underplating. Geochemistry, Geophysics, Geosystems, 11(10).

Bebout, G. (2014). Chemical and Isotopic Cycling in Subduction Zones. In Holland, H., \& Turekian, K. (Eds.). Treatise on geochemistry (2nd ed.). Elsevier, 4, 703-747.

Bernal, N. F., Gleeson, S. A., Dean, A. S., Liu, X.-M. \& Hoskin, P. (2014). The source of halogens in geothermal fluids from the Taupo Volcanic Zone, North Island, New Zealand. Geochimica et Cosmochimica Acta, 126(C), 265-283. 
Bevis, M. et al. (1995). Geodectic observations of very rapid convergence and back-arc extension at the Tonga arc. Nature, 374, 249-251.

Bird, P. (2003). An updated digital model of plate boundaries. Geochemistry, Geophysics, Geosystems, 4(3).

Blundy, J., Mavrogenes, J., Tattitch, B., Sparks, S. \& Gilmer, A. (2015). Generation of porphyry copper deposits by gas-brine reaction in volcanic arcs. Nature Geoscience, 8(3), 235-240.

Bo, T., Katz, R. F., Shorttle, O. \& Rudge, J. F. (2018). The melting column as a filter of mantle trace-element heterogeneity. Geochemistry, Geophysics, Geosystems, 19(12), 4694-4721.

Bougault, H. \& Hekinian, R. (1974). Rift valley in the Atlantic Ocean near $36^{\circ} 50^{\prime} \mathrm{N}$ : petrology and geochemistry of basaltic rocks. Earth and Planetary Science Letters, 24(2), 249-261.

Burgisser, A. \& Scaillet, B. (2007). Redox evolution of a degassing magma rising to the surface. Nature, 445(7124), 194-197.

Carroll, M. \& Rutherford, M. (1988). Sulfur speciation in hydrous experimental glasses of varying oxidation state; results from measured wavelength shifts of sulfur Xrays. American Mineralogist, 73(7-8), 845-849.

Carter, R. M., Carter, L. \& McCave, I. N. (1996). Current controlled sediment deposition from the shelf to the deep ocean: the cenozoic evolution of circulation through the SW pacific gateway. Geologische Rundschau, 85(3), 438-451.

Cauzid, J., Philippot, P., Martinez-Criado, G., Ménez, B. \& Labouré, S. (2007). Contrasting Cu-complexing behaviour in vapour and liquid fluid inclusions from the Yankee Lode tin deposit, Mole Granite, Australia. Chemical Geology, 246(1-2), $39-54$.

Chazot, G., Menzies, M. A. \& Harte, B. (1996). Determination of partition coefficients between apatite, clinopyroxene, amphibole, and melt in natural spinel Iherzolites from Yemen: Implications for wet melting of the lithospheric mantle. Geochimica et Cosmochimica Acta, 60(3), 423-437. 
Cooke, D. R., Hollings, P., Wilkinson, J. J. \& Tosdal, R. M. (2013). Geochemistry of porphyry deposits. In Holland, H., \& Turekian, K. (Eds.). Treatise on geochemistry (2nd ed.). Elsevier, 357-381.

Cooper, L. B., Plank, T. \& Arculus, R. J. (2006). High water contents in Tonga Arc magmas. Geochimica et Cosmochimica Acta, 70(18), A111.

Danyushevsky, L. V. \& Plechov, P. (2011). Petrolog3: Integrated software for modeling crystallization processes. Geochemistry, Geophysics, Geosystems, 12(7).

Davies, J. \& Stevenson, D. (1992). Physical model of source region of subduction zone volcanics. Journal of Geophysical Research, 97(B2), 2037-2070.

Davy, B., Hoernle, K. \& Werner, R. (2008). Hikurangi Plateau: Crustal structure, rifted formation, and Gondwana subduction history. Geochemistry, Geophysics, Geosystems, 9(7).

Davy, B. \& Wood, R. (1994). Gravity and magnetic modelling of the Hikurangi Plateau. Marine Geology, 118(1-2), 139-151.

De Hoog, J. C. M., Mason, P. R. D. \& Van Bergen, M. J. (2001). Sulfur and chalcophile elements in subduction zones: Constraints from a laser ablation ICP-MS study of melt inclusions from Galunggung volcano, Indonesia. Geochimica et Cosmochimica Acta, 65(18), 3147-3164.

de Ronde, C. E. et al. (2007). Submarine hydrothermal activity along the mid-Kermadec Arc, New Zealand: Large-scale effects on venting. Geochemistry, Geophysics, Geosystems, 8(7).

de Ronde, C. E. et al. (2011). Submarine hydrothermal activity and gold-rich mineralization at Brothers Volcano, Kermadec Arc, New Zealand. Mineralium Deposita, 46(5-6), 541-584.

de Ronde, C. E. et al. (2014). The anatomy of a buried submarine hydrothermal system, Clark Volcano, Kermadec Arc, New Zealand. Economic Geology, 109(8), 22612292.

de Ronde, C. E., Baker, E. T., Massoth, G. J., Lupton, J. E., Wright, I. C., Feely, R. A. \& Greene, R. R. (2001). Intra-oceanic subduction-related hydrothermal venting, 
Kermadec volcanic arc, New Zealand. Earth and Planetary Science Letters, 193(34), 359-369.

de Ronde, C. E., Butterfield, D. A. \& Leybourne, M. I. (2012). Metallogenesis and Mineralization of Intraoceanic Arcs I: Kermadec Arc--Introduction. Economic Geology, 107(8), 1521-1525.

de Ronde, C. E., Faure, K., Bray, C. J., Chappell, D. A. \& Wright, I. C. (2003).

Hydrothermal fluids associated with seafloor mineralization at two southern Kermadec arc volcanoes, offshore New Zealand. Mineralium Deposita, 38(2), 217233.

de Ronde, C. E. et al. (2005). Evolution of a submarine magmatic-hydrothermal system: Brothers volcano, southern Kermadec Arc, New Zealand. Economic Geology, 100(6), 1097-1133.

DeMets, C., Gordon, R., Argus, D. \& Stein, S. (1994). Effect of recent revisions to the geomagnetic reversal time scale on estimates of current plate motions. Geophysical Research Letters, 21(20), 2191-2194.

Deschamps, F. \& Hattori, K. (2013). Geochemistry of subduction zone serpentinites: A review. Lithos, 178, 96-127.

Dixon, J. E., Stolper, E. \& Delaney, J. R. (1988). Infrared spectroscopic measurements of $\mathrm{CO} 2$ and $\mathrm{H} 2 \mathrm{O}$ in Juan de Fuca Ridge basaltic glasses. Earth and Planetary Science Letters, 90(1), 87-104.

Dixon, J. E. \& Stolper, E. M. (1995). An experimental study of water and carbon dioxide solubilities in mid-ccean ridge basaltic liquids. Part II: Applications to Degassing. Journal of Petrology, 36(6), 1633-1646.

Doe, B. R. (1994). Zinc, copper, and lead in mid-ocean ridge basalts and the source rock control on $\mathrm{Zn} / \mathrm{Pb}$ in ocean-ridge hydrothermal deposits. Geochimica et Cosmochimica Acta, 58(10), 2215-2223.

Domanik, K. J. \& Holloway, J. R. (1996). The stability and composition of phengitic muscovite and associated phases from 5.5 to $11 \mathrm{GPa}$ : Implications for deeply subducted sediments. Geochimica et Cosmochimica Acta, 60(21), 4133-4150. 
Eichelberger, J. (2002). Silicic volcanism: ascent of viscous magmas from crustal reservoirs. Annual Review of Earth and Planetary Sciences, 23(1), 41-63.

Eiler, J. (ed.) (2003). Inside the Subduction Factory. American Geophysical Union.

Elliott, T., Plank, T., Zindler, A., White, W. \& Bourdon, B. (1997). Element transport from slab to volcanic front at the Mariana arc. Journal of Geophysical Research: Solid Earth, 102(B7), 14991-15019.

Ewart, A., Collerson, K. D., Regelous, M., Wendt, J. I. \& Niu, Y. (1998). Geochemical evolution within the Tonga-Kermadec-Lau Arc-Back-arc systems: The role of varying mantle wedge composition in space and time. Journal of Petrology, 39(3), 331-368.

Fine, G. \& Stolper, E. (1985). The speciation of carbon dioxide in sodium aluminosilicate glasses. Contributions to Mineralogy and Petrology, 91(2), 105121.

Frezzotti, M.-L. (2001). Silicate-melt inclusions in magmatic rocks: applications to petrology. Lithos, 55(1-4), 273-299.

Gale, A., Dalton, C. A., Langmuir, C. H., Su, Y. \& Schilling, J.-G. (2013). The mean composition of ocean ridge basalts. Geochemistry, Geophysics, Geosystems, 14(3), $489-518$.

Gamble, J. A., Christie, R. H. K., Wright, I. C. \& Wysoczanski, R. J. (1997). Primitive K-rich magmas from Clark volcano, southern Kermadec Arc: A paradox in the K - Depth relationship. Canadian Mineralogist, 35(2), 275-290.

Gamble, J. A., Smith, I. E. M., Graham, I. J., Peter Kokelaar, B., Cole, J. W., Houghton, B. F. \& Wilson, C. J. N. (1990). The petrology, phase relations and tectonic setting of basalts from the taupo volcanic zone, New Zealand and the Kermadec Island arc havre trough, SW Pacific. Journal of Volcanology and Geothermal Research, 43(1), 253-270.

Gamble, J. A., Smith, I. E. M., McCulloch, M. T., Graham, I. J. \& Kokelaar, B. P. (1993a). The geochemistry and petrogenesis of basalts from the Taupo Volcanic Zone and Kermadec Island Arc, S.W. Pacific. Journal of Volcanology and Geothermal 
Research, 54(3-4), 265-290.

Gamble, J. A., Wright, I. C. \& Baker, J. A. (1993b). Seafloor geology and petrology in the oceanic to continental transition zone of the Kermadec-Havre-Taupo Volcanic Zone arc system, New Zealand. New Zealand Journal of Geology and Geophysics, 36(4), 417-435.

Gamble, J., Smith, I. E. M., McCulloch, M. T., Graham, I. J. \& Kokelaar, B. P. (1993c). The geochemistry and petrogenesis of basalts from the Taupo Volcanic Zone and Kermadec Island Arc, S.W. Pacific. Journal of Volcanology and Geothermal Research, 54(3-4), 265-290.

Gamble, J., Woodhead, J., Wright, I. \& Smith, I. (1996). Basalt and sediment geochemistry and magma petrogenesis in a transect from oceanic island arc to rifted continental margin arc: The Kermadec-Hikurangi Margin, SW Pacific. Journal of Petrology, 37(6), 1523-1546.

Gamble, J. \& Wright, I. (1995). The Southern Havre Trough Geological Structure and Magma Petrogenesis of an Active Backarc Rift Complex. In Taylor, B. (Ed) Backarc Basins, 29-62. New York: Plenum Press.

German, C. R. \& Von Damm, K. L. (2003). Hydrothermal processes. In Holland, H., \& Turekian, K. (Eds.). Treatise on geochemistry. Elsevier. 1-9, 181-222.

Gill, J. (1981). Orogenic Andesites and Plate Tectonics. Berlin; New York: SpringerVerlag.

Haase, K. M., Stroncik, N., Garbe-Schönberg, D. \& Stoffers, P. (2006). Formation of island arc dacite magmas by extreme crystal fractionation: An example from Brothers Seamount, Kermadec island arc (SW Pacific). Journal of Volcanology and Geothermal Research, 152(3-4), 316-330.

Haase, K. M., Worthington, T. J., Stoffers, P., Garbe-Schönberg, D. \& Wright, I. (2002). Mantle dynamics, element recycling, and magma genesis beneath the Kermadec Arc-Havre Trough. Geochemistry, Geophysics, Geosystems, 3(11), 1-22.

Hamlyn, P. R., Keays, R. R., Cameron, W. E., Crawford, A. J. \& Waldron, H. M. (1985). Precious metals in magnesian low-Ti lavas: Implications for metallogenesis and 
sulfur saturation in primary magmas. Geochimica et Cosmochimica Acta, 49(8), $1797-1811$.

Hannington, M. D. (2014). Volcanogenic massive sulfide deposits. In: Holland, H. D. \& Turekian, K. K. (eds) Treatise on Geochemistry (2nd ed.). Eslevier. 463-488.

Hart, S. R. \& Dunn, T. (1993). Experimental cpx/melt partitioning of 24 trace elements. Contributions to Mineralogy and Petrology, 113(1), 1-8.

Hatherton, T. \& Dickinson, W. R. (1969). The relationship between andesitic volcanism and seismicity in Indonesia, the Lesser Antilles, and other island arcs. Journal of Geophysical Research, 74(22), 5301-5310.

Hattori, K. H. \& Guillot, S. (2003). Volcanic fronts form as a consequence of serpentinite dehydration in the forearc mantle wedge. Geology, 31(6), 525.

Hauri, E. H., Wagner, T. P. \& Grove, T. L. (1994). Experimental and natural partitioning of Th, $\mathrm{U}, \mathrm{Pb}$ and other trace elements between garnet, clinopyroxene and basaltic melts. Chemical Geology, 117(1-4), 149-166.

Heinrich, C. A., Gunther, D., Audetat, A., Ulrich, T. \& Frischknecht, R. (1999). Metal fractionation between magmatic brine and vapor, determined by microanalysis of fluid inclusions. Geology, 27, 755-758.

Heinrich, C. A., Ryan, G., Mernagh, T. \& Eadington, P. (1992). Segregation of ore metals between magmatic brine and vapor: a fluid inclusion study using PIXE microanalysis. Economic Geology, 87, 1566-1583.

Hermann, J., Spandler, C., Hack, A. \& Korsakov, A. V. (2006). Aqueous fluids and hydrous melts in high-pressure and ultra-high pressure rocks: Implications for element transfer in subduction zones. Lithos, 92(3-4), 399-417.

Hertogen, J., Janssens, M.-J. \& Palme, H. (1980). Trace elements in ocean ridge basalt glasses: implications for fractionations during mantle evolution and petrogenesis. Geochimica et Cosmochimica Acta, 44(12), 2125-2143.

Hildreth, W. \& Moorbath, S. (1988). Crustal contributions to arc magmatism in the Andes of Central Chile. Contributions to Mineralogy and Petrology, 98(4), 455489. 
Hoernle, K., Hauff, F., van den Bogaard, P., Werner, R., Mortimer, N., Geldmacher, J., Garbe-Schönberg, D. \& Davy, B. (2010). Age and geochemistry of volcanic rocks from the Hikurangi and Manihiki oceanic Plateaus. Geochimica et Cosmochimica Acta, 74(24), 7196-7219.

Holloway, J. R. \& Jakobsson, S. (1986). Volatile solubilities in magmas: Transport of volatiles from mantles to planet surfaces. Proceedings of the sixtenth lunar and planetary science conference.

Isacks, B. L. \& Barazangi, M. (1977). Geometry of benioff zones: Lateral segmentation and downwards bending of the subducted lithosphere. In: Talwani, M. \& Pitman, W. (eds.) Island Arcs, Deep Sea Trenches and Back-Arc Basins, 99-114.

Ito, E., Harris, D. M. \& Anderson, A. T. (1983). Alteration of oceanic crust and geologic cycling of chlorine and water. Geochimica et Cosmochimica Acta, 47(9), 16131624.

Jadamec, M. A. \& Billen, M. I. (2010). Reconciling surface plate motions with rapid three-dimensional mantle flow around a slab edge. Nature, 465(7296), 338-341.

Jambon, A., Déruelle, B., Dreibus, G. \& Pineau, F. (1995). Chlorine and bromine abundance in MORB: the contrasting behaviour of the Mid-Atlantic Ridge and East Pacific Rise and implications for chlorine geodynamic cycle. Chemical Geology, 126(2), 101-117.

Jarosewich, E., Nelen, J. A. \& Norberg, J. A. (1980). Referance samples for electron microprobe analysis. Geostandards Newsletter, 4(1), 43-47.

Jenner, F. E., Hauri, E. H., Bullock, E. S., König, S., Arculus, R. J., Mavrogenes, J. A., Mikkelson, N. \& Goddard, C. (2015). The competing effects of sulfide saturation versus degassing on the behavior of the chalcophile elements during the differentiation of hydrous melts. Geochemistry, Geophysics, Geosystems, 16(5), 1490-1507.

Jenner, F. E., O'Neill, H. S. C., Arculus, R. J. \& Mavrogenes, J. A. (2010). The magnetite crisis in the evolution of arc-related magmas and the initial concentration of $\mathrm{Au}$, Ag and Cu. Journal of Petrology, 51(12), 2445-2464. 
Jenner, G. A., Foley, S. F., Jackson, S. E., Green, T. H., Fryer, B. J. \& Longerich, H. P. (1993). Determination of partition coefficients for trace elements in high pressure-temperature experimental run products by laser ablation microprobeinductively coupled plasma-mass spectrometry (LAM-ICP-MS). Geochimica et Cosmochimica Acta, 57(23-24), 5099-5103.

Jochum, K. P. \& Enzweiler, J. (2014). Reference materials in geochemical and environmental research. In Holland, H., \& Turekian, K. (Eds.). Treatise on geochemistry (2nd ed.). Elsevier. 15, 43-70.

Jochum, K. P. \& Verma, S. P. (1996). Extreme enrichment of Sb, Tl and other trace elements in altered MORB. Chemical Geology, 130(3-4), 289-299.

Johnson, M. C. \& Plank, T. (2000). Dehydration and melting experiments constrain the fate of subducted sediments. Geochemistry, Geophysics, Geosystems, 1(12).

Jugo, P. J. (2009). Sulfur content at sulfide saturation in oxidized magmas. Geology, $37(5), 415-418$.

Kelley, K. A., Cottrell, E., Chin, E. J., Bouchet, R., Dasgupta, R., Morton, D. M., Roux, V. Le, Yin, Q. \& Jin, D. (2009). Water and the oxidation state of subduction zone magmas. Science (New York, N.Y.), 325(5940), 605-7.

Kelley, K. A., Plank, T., Grove, T. L., Stolper, E. M., Newman, S. \& Hauri, E. (2006). Mantle melting as a function of water content beneath back-arc basins. Journal of Geophysical Research: Solid Earth, 111(9).

Kent, A. J. R. \& Elliott, T. R. (2002). Melt inclusions from Marianas arc lavas: implications for the composition and formation of island arc magmas. Chemical Geology, 183(1-4), 263-286.

Kent, A. J. R., Peate, D. W., Newman, S., Stolper, E. M. \& Pearce, J. A. (2002). Chlorine in submarine glasses from the Lau Basin: seawater contamination and constraints on the composition of slab-derived fluids. Earth and Planetary Science Letters, 202(2), 361-377.

Kessel, R., Schmidt, M. W., Ulmer, P. \& Pettke, T. (2005). Trace element signature of subduction-zone fluids, melts and supercritical liquids at 120-180 km depth. 
Nature, 437(7059), 724-727.

Klock, W. \& Palme, H. (1988). Partitioning of siderophile and chalcophile elements between sulfide, olivine and glass in a naturally reduced basalt from Disko Island, Greenland. Proceedings of Planetary Science Conference, 18, 471-483.

Kogiso, T., Tatsumi, Y. \& Nakano, S. (1997). Trace element transport during dehydration processes in the subducted oceanic crust: 1 . Experiments and implications for the origin of ocean island basalts. Earth and Planetary Science Letters, 148(1), 193-205.

Koppers, A. A. P., Duncan, R. A. \& Steinberger, B. (2004). Implications of a nonlinear 40Ar/39Ar age progression along the Louisville seamount trail for models of fixed and moving hot spots. Geochemistry, Geophysics, Geosystems, 5(6).

Kravuchuk, I., Chernysheva, I. \& Urosov, S. (1981). Element distribution between plagioclase and groundmass as an indicator for crystallization conditions of the basalts in the southern vent of Tolbachik. Geochemistry International, 17, 18-24.

Kumagai, H. \& Kaneoka, I. (2003). Relationship between submarine MORB glass textures and atmospheric component of MORBs. Chemical Geology, 200(1-2), 124.

Kusakabe, M., Komoda, Y., Takano, B. \& Abiko, T. (2000). Sulfur isotopic effects in the disproportionation reaction of sulfur dioxide in hydrothermal fluids: implications for the $\delta 34 S$ variations of dissolved bisulfate and elemental sulfur from active crater lakes. Journal of Volcanology and Geothermal Research, 97(1-4), 287-307.

Landtwing, M. R., Pettke, T., Halter, W. E., Heinrich, C. A., Redmond, P. B., Einaudi, M. T. \& Kunze, K. (2005). Copper deposition during quartz dissolution by cooling magmatic-hydrothermal fluids: The Bingham porphyry. Earth and Planetary Science Letters, 235(1-2), 229-243.

Lange, R. A. (1997). A revised model for the density and thermal expansivity of K2ONa2O-CaO-MgO-Al2O3-SiO2 liquids from 700 to $1900 \mathrm{~K}$ : extension to crustal magmatic temperatures. Contributions to Mineralogy and Petrology, 130(1), 111. 
Large, R. R., Doyle, M., Raymond, O., Cooke, D., Jones, A. \& Heasman, L. (1996). Evaluation of the role of cambrian granites in the genesis of world class VHMS deposits in Tasmania. Ore Geology Reviews, 10, 215-230.

Laubier, M., Gale, A. \& Langmuir, C. H. (2012). Melting and crustal processes at the FAMOUS segment (Mid-Atlantic Ridge): New insights from olivine-hosted melt inclusions from multiple samples. Journal of Petrology, 53(4), 665-698.

Le Maitre, R. et al. (2002). Igneous rocks: a classification and glassary of terms, recommendations of the international union of geological sciences, subcommission on the systematics of igneous rocks. Cambridge University Press.

Lee, C.-T. A., Brandon, A. D. \& Norman, M. (2003). Vanadium in peridotites as a proxy for paleo-fO2 during partial melting: prospects, limitations, and implications. Geochimica et Cosmochimica Acta, 67(16), 3045-3064.

Leeman, W. P., Smith, D. R., Hildreth, W., Palacz, Z. \& Rogers, N. (1990). Compositional diversity of Late Cenozoic basalts in a transect across the southern Washington Cascades: Implications for subduction zone magmatism. Journal of Geophysical Research, 95(B12), 19561.

Lesne, P., Kohn, S. C., Blundy, J., Witham, F., Botcharnikov, R. E. \& Behrens, H. (2011). Experimental simulation of closed-system degassing in the system basalt-H2OCO2-S-Cl. Journal of Petrology, 52(9), 1737-1762.

Leybourne, M. I. et al. (2012). Geology, hydrothermal activity, and sea-floor massive sulfide mineralization at the Rumble II West Mafic Caldera. Economic Geology, 107(8), 1649-1668.

Long, M. D. \& Silver, P. G. (2008). The subduction zone flow field from seismic anisotropy: A global view. Source: Science, New Series, 319(5861), 315-318.

Lowenstern, J. (1995). Applications of silicate-melt inclusions to the study of magmatic volatiles. In: Thompson, J. (ed.) Magmas, Fluids, and Ore Deposits, 71-99.

Lu, F., Anderson, A. T. \& Davis, A. M. (1995). Diffusional gradients at the crystal/melt interface and their effect on the composition of melt inclusions. The Journal of Geology, 591-597. 
Luhr, J. F. (1990). Experimental phase relations of water- and sulfur-saturated arc magmas and the 1982 eruptions of El chichón volcano. Journal of Petrology, 31(5), $1071-1114$

Luhr, J. F. (2001). Glass inclusions and melt volatile contents at Parícutin Volcano, Mexico. Contributions to Mineralogy and Petrology, 142(3), 261-283.

Maclennan, J. (2008). Lead isotope variability in olivine-hosted melt inclusions from Iceland. Geochimica et Cosmochimica Acta, 72(16), 4159-4176.

Malahoff, A., Feden, R. H. \& Fleming, H. S. (1982). Magnetic anomalies and tectonic fabric of marginal basins north of New Zealand. Journal of Geophysical Research, 87(B5), 4109.

Manning, C. E. (2006). What's so super about supercritical fluids in subduction zones? Geochimica et Cosmochimica Acta, 70(18), A388.

Marsh, B. D. \& Carmichael, I. S. E. (1974). Benioff zone magmatism. Journal of Geophysical Research, 79(8), 1196-1206.

Mathez, E. A. (1984). Influence of degassing on oxidation states of basaltic magmas. Nature, 310(5976), 371-375.

Matsui, Y., Onuma, N., Nagasawa, H., Higuchi, H. \& Banno, S. (1977). Crystal structure control in trace element partition between crystal and magma. Tectonics, 100, $315-324$

McCulloch, M. T. \& Gamble, J. A. (1991). Geochemical and geodynamical constraints on subduction zone magmatism. Earth and Planetary Science Letters, 102(3), 358374.

McKenzie, D. \& O'Nions, R. (1991). Partial melt distributions from inversion of rare Earth element concentrations. Journal of Petrology, 32, 1021-1091.

Melson, W. G., O'Hearn, T. \& Jarosewich, E. (2002). A data brief on the Smithsonian Abyssal Volcanic Glass Data File. Geochemistry, Geophysics, Geosystems, 3(4), 111.

Métrich, N., Schiano, P., Clocchiatti, R. \& Maury, R. C. (1999). Transfer of sulfur in subduction settings: an example from Batan Island (Luzon volcanic arc, 
Philippines). Earth and Planetary Science Letters, 167(167), 1-14.

Mortimer, N., Gans, P. B., Palin, J. M., Meffre, S., Herzer, R. H. \& Skinner, D. N. B. (2010). Location and migration of Miocene-Quaternary volcanic arcs in the SW Pacific region.(Report). Journal of Volcanology and Geothermal Research, 190(12), 1-10.

Mungall, J. E. (2002). Roasting the mantle: Slab melting and the genesis of major $\mathrm{Au}$ and Au-rich Cu deposits. Geology, 30(10), 915.

Neal, C. R., Mahoney, J. J., Kroenke, L. W., Duncan, R. A. \& Petterson, M. G. (1997). The Ontong Java Plateau. Geophysical Monograph, 100, 183-216.

Neave, D. A., Shorttle, O., Oeser, M., Weyer, S. \& Kobayashi, K. (2018). Mantle-derived trace element variability in olivines and their melt inclusions. Earth and Planetary Science Letters, 483, 90-104.

Newman, S. \& Lowenstern, J. B. (2002). VolatileCalc: a silicate melt-H2O-CO2 solution model written in Visual Basic for excel. Computers \& Geosciences, 28(5), 597-604.

Ni, H., Zhang, L., Xiong, X., Mao, Z. \& Wang, J. (2017). Supercritical fluids at subduction zones: Evidence, formation condition, and physicochemical properties. EarthScience Reviews, 167, 62-71.

Nichols, A. R. L. \& Wysoczanski, R. J. (2007). Using micro-FTIR spectroscopy to measure volatile contents in small and unexposed inclusions hosted in olivine crystals. Chemical Geology, 242(3-4), 371-384.

Nichols, G. T., Wyllie, P. J. \& Stern, C. R. (1994). Subduction zone melting of pelagic sediments constrained by melting experiments. Nature, 371(6500), 785-788.

Nielsen, R. L. (1985). EQUIL: a program for the modeling of low-pressure differentiation processes in natural mafic magma bodies. Computers and Geosciences, 11(5), 531-546.

Nishikida, K., Nishio, E. \& Hannah, R. (1995). Selected applications of modern FT-IR techniques. Gordon and Breach.

Noll, P. D., Newsom, H. E., Leeman, W. P. \& Ryan, J. G. (1996). The role of hydrothermal fluids in the production of subduction zone magmas: Evidence from 
siderophile and chalcophile trace elements and boron. Geochimica et Cosmochimica Acta, 60(4), 587-611.

Ono, S. (1998). Stability limits of hydrous minerals in sediment and mid-ocean ridge basalt compositions: Implications for water transport in subduction zones. Journal of Geophysical Research: Solid Earth, 103(B8), 18253-18267.

Parson, L. M. \& Wright, I. C. (1996). The Lau-Havre-Taupo back-arc basin: A southwardpropagating, multi-stage evolution from rifting to spreading. Tectonophysics, 263(1), 1-22.

Paster, T. P., Schauwecker, D. S. \& Haskin, L. A. (1974). The behavior of some trace elements during solidification of the Skaergaard layered series. Geochimica et Cosmochimica Acta, 38(10), 1549-1577.

Peacock, S. M. (1996). Thermal and petrologic structure of subduction zones. Geophysical Monograph, 96, 119-133.

Pearce, J. A. \& Peate, D. W. (1995). Tectonic implications of the composition of volcanic arc magmas. Annual Review of Earth and Planetary Sciences, 23, 251285.

Pearce, J. A. \& Stern, R. J. (2006). Origin of back-arc basin magmas: Trace element and isotope perspectives. Geophysical Monograph Series, 63-86.

Peate, D. W., Kokfelt, T. F., Hawkesworth, C. J., Van Calsteren, P. W., Hergt, J. M. \& Pearce, J. A. (2001). U-series isotope data on Lau Basin glasses: The role of subduction-related fluids during melt generation in back-arc basins. Journal of Petrology, 42(8), 1449-1470.

Pelletier, B. \& Louat, R. (1989). Seismotectonics and present-day relative plate motions in the Tonga-Lau and Kermadec-Havre region. Elsevier Science Publishers B.V, 165, 237-250.

Peters, D., Bretscher, A., John, T., Scambelluri, M. \& Pettke, T. (2017). Fluid-mobile elements in serpentinites: Constraints on serpentinisation environments and element cycling in subduction zones. Chemical Geology, 466, 654-666.

Plank, T. (1998). The chemical compositions of subducting sediments and its 
consequences for the crust and mantle. Chemical Geology, 145, 325-394.

Plank, T. (2014). The chemical composition of subducting sediments. In Holland, H., \& Turekian, K. (Eds.). Treatise on geochemistry (2nd ed.). Elsevier. 607-629.

Plank, T. \& Langmuir, C. H. (1998). The chemical composition of subducting sediment and its consequences for the crust and mantle. Chemical Geology, 145(3-4), 325394.

Pokrovski, G., Roux, J. \& Harrichoury, J. (2005). Fluid density control on vapor-liquid partitioning of metals in hydrothermal systems. Geology, 33, 657-660.

Pokrovski, G. S., Borisova, A. Y. \& Harrichoury, J.-C. (2008). The effect of sulfur on vapor-liquid fractionation of metals in hydrothermal systems. Earth and Planetary Science Letters, 266(3-4), 345-362.

Portnyagin, M., Hoernle, K., Plechov, P., Mironov, N. \& Khubunaya, S. (2007). Constraints on mantle melting and composition and nature of slab components in volcanic arcs from volatiles $(\mathrm{H} 2 \mathrm{O}, \mathrm{S}, \mathrm{Cl}, \mathrm{F})$ and trace elements in melt inclusions from the Kamchatka Arc. Earth and Planetary Science Letters, 255(1-2), 53-69.

Pullan, V. (2018). Geomorphology and geochemistry of back arc basins in the Havre Trough, Southwest Pacific (Master's thesis). Available from Victoria University of Wellington Library.

Regelous, M., Gamble, J. A. \& Turner, S. P. (2010). Mechanism and timing of Pb transport from subducted oceanic crust and sediment to the mantle source of arc lavas. Chemical Geology, 273(1-2), 46-54.

Reyners, M., Eberhart-Phillips, D. \& Bannister, S. (2011). Tracking repeated subduction of the Hikurangi Plateau beneath New Zealand. Earth and Planetary Science Letters, 311(1), 165-171.

Richards, J. P. (2003). Tectono-magmatic precursors for porphyry Cu-(Mo-Au) deposit formation. Economic Geology, 98(8), 1515-1533.

Richards, J. P. (2011). Magmatic to hydrothermal metal fluxes in convergent and collided margins. Ore Geology Reviews, 40(1), 1-26.

Roedder, E. (1984). Fluid inclusions. Reviews in Mineralogy, 12, Mineralogical Society 
of America, 646.

Roeder, P. L. \& Emslie, R. F. (1970). Olivine-liquid equilibrium. Contributions to Mineralogy and Petrology, 29(4), 275-289.

Rowe, M. C., Kent, A. J. R. \& Nielsen, R. L. (2007). Determination of sulfur speciation and oxidation state of olivine hosted melt inclusions. Chemical Geology, 236(3-4), 303-322.

Ruellan, E., Delteil, J., Wright, I. \& Matsumoto, T. (2003). From rifting to active spreading in the Lau Basin - Havre Trough backarc system (SW Pacific): Locking/unlocking induced by seamount chain subduction. Geochemistry, Geophysics, Geosystems, 4(5).

Rüpke, L. H., Morgan, J. P., Hort, M. \& Connolly, J. (2004). Serpentinite and the subduction zone water cycle. Earth and Planetary Science Letters, 223(1-2), 1734.

Ryan, J. G. \& Chauvel, C. (2013). The subduction-zone filter and the impact of recycled materials on the evolution of the mantle. In Holland, H., \& Turekian, K. (Eds.). Treatise on geochemistry (2nd ed.). Elsevier. 479-508.

Ryan, Morris, J. G., Tera, J., Leeman, F., Tsvetkov, W. P. \& Andrei (1995). Cross-arc geochemical variations in the Kurile arc as a function of slab depth. Science, 270(5236).

Schellart, W. P. \& Spakman, W. (2012). Mantle constraints on the plate tectonic evolution of the Tonga-Kermadec-Hikurangi subduction zone and the South Fiji Basin region. Australian Journal of Earth Sciences, 59(6), 933-952.

Schilling, J.-G., Unni, C. K. \& Bender, M. L. (1978). Origin of chlorine and bromine in the oceans. Nature, 1978 273:5664, 273(5664), 631.

Schmidt, M. \& Poli, S. (2014). Devolatilization during subduction. In Holland, H., \& Turekian, K. (Eds.). Treatise on geochemistry (2nd ed.). Elsevier. 4, 669-701.

Schmidt, M. W. \& Poli, S. (2003). Generation of Mobile Components during Subduction of oceanic crust. In Holland, H., \& Turekian, K. (Eds.). Treatise on geochemistry. Elsevier. 567-591. 
Scott, S. D. (1997). Submarine hydrothermal systems. In: Barnes, H. L. (ed.) Geochemistry of Hydrothermal Ore Deposits. New York: Holt, Rinehart and Winston. $797-875$.

Seo, J. H., Guillong, M. \& Heinrich, C. A. (2009). The role of sulfur in the formation of magmatic-hydrothermal copper-gold deposits. Earth and Planetary Science Letters, 282(1-4), 323-328.

Simon, A. C., Pettke, T., Candela, P. A., Piccoli, P. M. \& Heinrich, C. A. (2006). Copper partitioning in a melt-vapor-brine-magnetite-pyrrhotite assemblage. Geochimica et Cosmochimica Acta, 70(22), 5583-5600.

Singer, B. S., Jicha, B. R., Leeman, W. P., Rogers, N. W., Thirlwall, M. F., Ryan, J. \& Nicolaysen, K. E. (2007). Along-strike trace element and isotopic variation in Aleutian Island arc basalt: Subduction melts sediments and dehydrates serpentine. Journal of Geophysical Research, 112(B6), B06206.

Smith, G. P., Wiens, D. A., Fischer, K. M. \& Dorman, L. M. (2001). A complex pattern of mantle flow in the Lau Backarc. Science, 292(5517), 713-716.

Smith, I. E. M., Price, R. C., Stewart, R. B. \& Worthington, T. J. (2009). An assessment of the mantle and slab components in the magmas of an oceanic arc volcano: Raoul Volcano, Kermadec arc. Journal of Volcanology and Geothermal Research, 184(34), 437-450.

Smith, I. E. M., Stewart, R. B. \& Price, R. C. (2003). The petrology of a large intraoceanic silicic eruption: the Sandy Bay Tephra, Kermadec Arc, Southwest Pacific. Journal of Volcanology and Geothermal Research, 124(3), 173-194.

Spandler, C., Hermann, J., Arculus, R. \& Mavrogenes, J. (2004). Geochemical heterogeneity and element mobility in deeply subducted oceanic crust; insights from high-pressure mafic rocks from New Caledonia. Chemical Geology, 206(1-2), 21-42.

Stanton, R. L. (1990). Magmatic evolution and the ore type-lava affiliations of volcanic exhalative ores. Australian Institute of Mining Metallurgy Monograph, 14, 101107. 
Stanton, R. L. (1994). Ore elements in arc lavas. Oxford Monographs on Geology and Geophysics, 29.

Stolper, E. \& Newman, S. (1994). The role of water in the petrogenesis of Mariana trough magmas. Earth and Planetary Science Letters, 121(3-4), 293-325.

Sun, S. \& McDonough, W. F. (1989). Chemical and isotopic systematics of oceanic basalts: implications for mantle composition and processes. Geological Society, London, Special Publications, 42(1), 313-345.

Syracuse, E. M., van Keken, P. E. \& Abers, G. A. (2010). The global range of subduction zone thermal models. Physics of the Earth and Planetary Interiors, 183(1-2), 7390.

Takahashi, N. et al. (2009). Structural variations of arc crusts and rifted margins in the southern Izu-Ogasawara arc-back arc system. Geochemistry, Geophysics, Geosystems, 10(9).

Tamura, Y., Tani, K., Chang, Q., Shukuno, H., Kawabata, H., Ishizuka, O. \& Fiske, R. S. (2007). Wet and dry basalt magma evolution at Torishima Volcano, Izu-Bonin Arc, Japan: the Possible role of phengite in the downgoing slab. Journal of Petrology, 48(10), 1999-2031.

Tamura, Y., Tatsumi, Y., Zhao, D., Kido, Y. \& Shukuno, H. (2002). Hot fingers in the mantle wedge: new insights into magma genesis in subduction zones. Earth and Planetary Science Letters, 197(1-2), 105-116.

Taylor, B. \& Martinez, F. (2003). Back-arc basin basalt systematics. Earth and Planetary Science Letters, 210(3-4), 481-497.

Taylor, B., Zellmer, K., Martinez, F. \& Goodliffe, A. (1996). Sea-floor spreading in the Lau back-arc basin. Earth and Planetary Science Letters, 144(1), 35-40.

Timm, C. et al. (2014). Subduction of the oceanic Hikurangi Plateau and its impact on the Kermadec arc. Nature Communications, 5(1), 4923.

Timm, C., Bassett, D., Graham, I. J., Leybourne, M. I., de Ronde, C. E. J., Woodhead, J., Layton-Matthews, D. \& Watts, A. B. (2013). Louisville seamount subduction and its implication on mantle flow beneath the central Tonga-Kermadec arc. Nature 
Communications, 4(1), 1720.

Timm, C., de Ronde, C. E. J., Hoernle, K., Cousens, B., Wartho, J.-A., Caratori-Tontini, F., Wysoczanski, R., Hauff, F. \& Handler, M. (In Rewview). New age and geochemical data from the southern Colville and Kermadec Ridges, SW Pacific: Isights into the recent geological history and petrogenesis of the Proto-Kermadec (Vitiaz) Arc. Gondwana Research,

Timm, C., De Ronde, C. E. J., Leybourne, M. I., Layton-Matthews, D. \& Graham, I. J. (2012). Sources of chalcophile and siderophile elements in kermadec Arc Lavas. Economic Geology, 107(8), 1527-1538.

Timm, C., Leybourne, M., Hoernle, K., Wysoczanski, R., Hauff, F., Handler, M., Tontini, F. \& de Ronde, C. E. J. (2016). Trench-perpendicular geochemical variation between two adjacent Kermadec Arc volcanoes Rumble II East and West: the role of the subducted Hikurangi Plateau in element recycling in Arc Magmas. Journal of Petrology, 57(7), 1335-1360.

Todd, E., Gill, J. B., Wysoczanski, R. J., Handler, M. R., Wright, I. C. \& Gamble, J. A. (2010). Sources of constructional cross-chain volcanism in the southern Havre Trough: New insights from HFSE and REE concentration and isotope systematics. Geochemistry, Geophysics, Geosystems, 11(4).

Todd, E., Gill, J. B., Wysoczanski, R. J., Hergt, J., Wright, I. C., Leybourne, M. I. \& Mortimer, N. (2011). Hf isotopic evidence for small-scale heterogeneity in the mode of mantle wedge enrichment: Southern Havre Trough and South Fiji Basin back arcs. Geochemistry, Geophysics, Geosystems, 12(9).

Tontini, F. C., de Ronde, C. E., Kinsey, J. C., Soule, A., Yoerger, D. \& Cocchi, L. (2013). Geophysical modeling of collapse-prone zones at Rumble III seamount, southern Pacific Ocean, New Zealand. Geochemistry, Geophysics, Geosystems, 14(10), 4667-4680.

Turner, S., Hawkesworth, C., Rogers, N., Bartlett, J., Worthington, T., Hergt, J., Pearce, J. \& Smith, I. (1997). U-238-Th-230 disequilibria, magma petrogenesis, and flux rates beneath the depleted Tonga-Kermadec island arc. Geochimica et Cosmochimica Acta, 4855-4884. 
Urabe, T. (1987). Kuroko deposit modeling based on magmatic hydrothermal theory. Mining Geology, 37, 159-176.

von Aulock, F. W. et al. (2014). Advances in Fourier transform infrared spectroscopy of natural glasses: From sample preparation to data analysis. Lithos, 206-207, 5264.

Walker, Patino, L. C., Cameron, B. I. \& Carr, M. J. (2000). Petrogenetic insights provided by compositional transects across the Central American arc: Southeastern Guatemala and Honduras. Journal of Geophysical Research: Solid Earth, 105(B8), 18949-18963.

Walker, Roggensack, K., Patino, L. C., Cameron, B. I. \& Matias, O. (2003). The water and trace element contents of melt inclusions across an active subduction zone. Contributions to Mineralogy and Petrology, 146(1), 62-77.

Walker, Teipel, A. P., Ryan, J. G. \& Syracuse, E. (2009). Light elements and Li isotopes across the northern portion of the Central American subduction zone. Geochemistry, Geophysics, Geosystems, 10(6).

Wallace, J., Plank, T., Edmonds, M. \& Hauri, E. (2015). Volatiles in Magmas. In Houghton, B., Rymer, H., Stix, J. (Eds.) The Encyclopedia of Volcanoes (2nd ed.), 163-183.

Wallace, P. J. (2005). Volatiles in subduction zone magmas: concentrations and fluxes based on melt inclusion and volcanic gas data. Journal of Volcanology and Geothermal Research, 140(1-3), 217-240.

Wallace, P. J. \& Edmonds, M. (2011). The Sulfur Budget in Magmas: Evidence from Melt Inclusions, Submarine Glasses, and Volcanic Gas Emissions. Reviews in Mineralogy and Geochemistry, 73(1), 215-246.

Webster, J. D., Kinzler, R. J. \& Mathez, E. A. (1999). Chloride and water solubility in basalt and andesite melts and implications for magmatic degassing. Geochimica et Cosmochimica Acta, 63(5), 729-738.

Wilson, C. J. N., Houghton, B. F., McWilliams, M. O., Lanphere, M. A., Weaver, S. D. \& Briggs, R. M. (1995). Volcanic and structural evolution of Taupo Volcanic Zone, 
New Zealand: a review. Journal of Volcanology and Geothermal Research, 68(1), $1-28$.

Wood, R. \& Davy, B. (1994). The Hikurangi Plateau. Marine Geology, 118(1), 153-173.

Woodhead, J., Eggins, S. \& Gamble, J. (1993). High field strength and transition element systematics in island arc and back-arc basin basalts: Evidence for multiphase melt extraction and a depleted mantle wedge. Earth and Planetary Science Letters, 114(4), 491-504.

Wright, I. (1994). Nature and tectonic setting of the southern Kermadec submarine arc volcanoes: An overview. Marine Geology, 118(3-4), 217-236.

Wright, I. (1997). Morphology and evolution of the remnant Colville and active

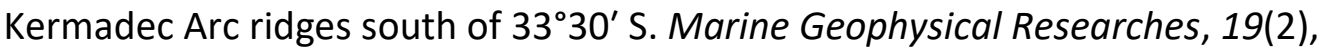
177-193.

Wright, I. C. (1993). Pre-spread rifting and heterogeneous volcanism in the southern Havre Trough back-arc basin. Marine Geology, 113(3), 179-200.

Wright, I., de Ronde, C., Faure, K. \& Gamble, J. (1998). Discovery of hydrothermal sulfide mineralization from southern Kermadec arc volcanoes (SW Pacific). Earth and Planetary Science Letters, 164(1-2), 335-343.

Wright, I. \& Gamble, J. (1999). Southern Kermadec submarine caldera arc volcanoes (SW Pacific): caldera formation by effusive and pyroclastic eruption. Marine Geology, 161(2-4), 207-227.

Wright, I., Parson, L. \& Gamble, J. (1996). Evolution and interaction of migrating crossarc volcanism and backarc rifting: An example from the Southern Havre Trough $\left(35^{\circ} 20^{\prime}-37^{\circ} \mathrm{S}\right)$. Journal of Geophysical Research: Solid Earth, 101(B10), 2207122086.

Wright, I., Stoffers, P., Hannington, M., de Ronde, C. E. J., Herzig, P., Smith, I. E. . \& Browne, P. R. (2002). Towed-camera investigations of shallow-intermediate water-depth submarine stratovolcanoes of the southern Kermadec arc, New Zealand. Marine Geology, 185(3-4), 207-218.

Wright, I., Worthington, T. J. \& Gamble, J. A. (2006). New multibeam mapping and 
geochemistry of the $30^{\circ}-35^{\circ} \mathrm{S}$ sector, and overview, of southern Kermadec arc volcanism. Journal of Volcanology and Geothermal Research, 149(3), 263-296.

Wysoczanski, R. J., Handler, M. R., Schipper, C. I., Leybourne, M. I., Creech, J., Rotella, M. D., Nichols, A. R. L., Wilson, C. J. N. \& Stewart, R. B. (2012). The tectonomagmatic source of ore metals and volatile elements in the Southern Kermadec Arc. Economic Geology, 107(8), 1539-1556.

Wysoczanski, R. J., Todd, E., Wright, I. C., Leybourne, M. I., Hergt, J. M., Adam, C. \& Mackay, K. (2010). Backarc rifting, constructional volcanism and nascent disorganised spreading in the southern Havre Trough backarc rifts (SW Pacific). Journal of Volcanology and Geothermal Research, 190(1), 39-57.

Wysoczanski, R. J., Wright, I. C., Gamble, J. A., Hauri, E. H., Luhr, J. F., Eggins, S. M. \& Handler, M. R. (2006). Volatile contents of Kermadec Arc-Havre Trough pillow glasses: Fingerprinting slab-derived aqueous fluids in the mantle sources of arc and back-arc lavas. Journal of Volcanology and Geothermal Research, 152(1), 5173.

Wysoczanski, R. \& Tani, K. (2006). Spectroscopic FTIR imaging of water species in silicic volcanic glasses and melt inclusions: An example from the Izu-Bonin arc. Journal of Volcanology and Geothermal Research, 156(3-4), 302-314.

Yang, K. \& Scott, S. D. (2006). Magmatic fluids as a source of metals in arc/back-arc hydrothermal systems: Evidence from melt inclusions and vesicles. In: Christie, D. M., Fisher, C. R. \& Lee, S.-M. (eds) Back-Arc Spreading Systems: Geological, Biological, Chemical and Physical Interactions. Geophysical Monograph Series, 166, 163-184.

Yi, W., Halliday, A. N., Alt, J. C., Lee, D.-C., Rehkämper, M., Garcia, M. O., Langmuir, C. H. \& Su, Y. (2000). Cadmium, indium, tin, tellurium, and sulfur in oceanic basalts: Implications for chalcophile element fractionation in the Earth. Journal of Geophysical Research: Solid Earth, 105(B8), 18927-18948.

Zajacz, Z. \& Halter, W. (2009). Copper transport by high temperature, sulfur-rich magmatic vapor: Evidence from silicate melt and vapor inclusions in a basaltic andesite from the Villarrica volcano (Chile). Earth and Planetary Science Letters, 
282(1-4), 115-121.

Zajacz, Z., Seo, J. H., Candela, P. A., Piccoli, P. M., Heinrich, C. A. \& Guillong, M. (2010). Alkali metals control the release of gold from volatile-rich magmas. Earth and Planetary Science Letters, 297(1-2), 50-56.

Zellmer, K. E. \& Taylor, B. (2001). A three-plate kinematic model for Lau Basin opening. Geochemistry, Geophysics, Geosystems, 2(5). 
Appendices 
All Appendices are located on the attached DVD.

\section{Appendix A:}

Table A-1:

Major and minor element contents of olivine crystal investigated in this study.

\section{Appendix B:}

Table B-1:

Original compositions (not normalised) of olivine-hosted melt inclusions from the SKAHT investigated in this study.

\section{Appendix C:}

Table C-1:

Final melt inclusion compositions (major and trace) of olivine-hosted melt inclusions from the SKAHT investigated in this study.

\section{Appendix D:}

Table D-1:

Major element analyses of groundmass glasses of the SKAHT samples (normalised).

Table D-2:

Trace element analyses of groundmass glasses from the SKAHT samples. 